\title{
Synthesis and Biological Properties of 2(5H)-Furanones Featuring Bromine Atoms on the Heterocyclic Ring and/or Brominated Substituents
}

\author{
Renzo Rossi ${ }^{* a}$, Marco Lessi, ${ }^{a}$ Chiara Manzini, ${ }^{a}$ Giulia Marianetti, ${ }^{b}$ Fabio Bellina*a \\ ${ }^{a}$ Dipartimento di Chimica e Chimica Industriale, Università di Pisa, Pisa, Italy \\ ${ }^{b}$ Scuola Normale Superiore, Piazza dei Cavalieri 7, Pisa, Italy
}

\begin{abstract}
This review with 263 references deals with the synthesis of unnatural and natural $2(5 H)$-furanone derivatives featuring bromine atoms on the heterocyclic ring and/or brominated substituents, which have been described in the literature since 1951 up to February 2016. The review has been organized on the basis of seven classes of brominated furanone derivatives that were synthesized. Where possible, experimental details of the syntheses have been reported. Furthermore, the biological properties of the target compounds, including their mutagenic, cytotoxic, enzymatic, antiinflammatory and photosynthetic inhibitory activities have been summarized, paying particular attention on the compounds that have demonstrated antimicrobial properties via inhibition of quorum sensing and biofilm formation
\end{abstract}

Keywords: Brominated 2(5H)-furanone derivatives, Regioselectivity, Marine natural products, Bioactivity, Antimicrobials, Quorum quenching 


\section{INTRODUCTION}

In the last four decades the chemistry of $2(5 H)$ furanones (also referred as 2-butenolides) has received great interest and has experienced a remarkable expansion as evidenced by numeous reviews [1-18]. This interest is largely justified by the fact that these heterocycles include biologically active natural compounds and substances possessing interesting biological properties such as mutagenic, cytotoxic, anti-inflammatory, fungicidal and antibacterial activities. Furthermore, intense research has been conducted on the synthesis of brominated $2(5 H)$ furanone derivatives as some compounds of this class have been found capable to block the bacterial quorum sensing (QS), i.e. the cell-to-cell communication of bacteria that include antibiotic resistant species [19,20], enhancing bacterial clearance [21] and preventing swarming motility [22] and the production of QS-regulated virulence factors, notably biofilm formation [22-26].

However, no updated review regarding a comprehensive description of the syntheses of natural and unnatural brominated $2(5 H)$-furanone derivatives and the biological properties associated to some of these heterocyclic compounds has been published so far. Only two reviews, which were published in 2004 and 2011 respectively, deal with the synthetic aspects of 3,4-dibromo-5-hydroxy$2(5 H)$-furanone (mucobromic acid) (1) $[10,14]$ and 3,4dibromo-2(5H)-furanone (2) (Figure 1)[14].

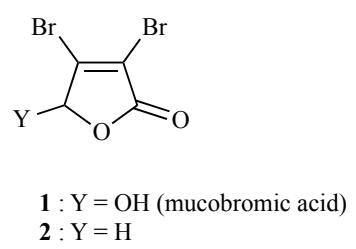

Figure 1. Structures of compounds $\mathbf{1}$ and $\mathbf{2}$

This review with 263 references aims to provide a thorough insight of the synthesis of $2(5 \mathrm{H})$-furanones with bromine atoms on the heterocyclic ring and/or brominated substituents that include natural products and unnatural compounds used in the literature as versatile synthetic intermediates. The review also focuses on the biological properties of the synthesized compounds with particular attention to those of the brominated compounds that have been found capable of interfering with the QS system of bacteria, especially of those that are cause of mortality and morbidity in human beings. The literature data on these topics have been organized on the basis of the structures of the target compounds and have been subdivided in the following sections interposed between the introduction and conclusion: i) synthesis and bioactivity of $2(5 H)-$ furanone derivatives with one bromine atom on the heterocyclic ring; ii) synthesis and bioactivity of $2(5 H)$ furanone derivatives with two bromine atoms on the heterocyclic ring; iii) synthesis and bioactivity of $2(5 H)$ furanone derivatives possessing one bromine atom on the heterocyclic ring and monobrominated substituents; iv) synthesis and bioactivity of $2(5 H)$-furanone derivatives featuring one bromine atom on the heterocyclic ring and dibrominated substituents; v) synthesis and bioactivity of $2(5 H)$-furanone derivatives featuring two bromine atoms on the heterocyclic ring and brominated substituents; vi) synthesis and bioactivity of $2(5 H)$-furanones with monobrominated substituents; and vii) synthesis and bioactivity of $2(5 H)$-furanones with di-, tri- and tetrabrominated substituents.

The literature has been surveyed from 1951 until the end of February 2016.

\section{SYNTHESES AND BIOACTIVITY OF 2(5H)- FURANONE DERIVATIVES WITH ONE BROMINE ATOM ON THE HETEROCYCLIC RING}

\subsection{SYNTHESIS AND BIOACTIVITY OF 3-BROMO- 2(5H)-FURANONE DERIVATIVES}

In 1979, Reffstrup and Boll investigated the bromination reaction of 4-methoxy-2(5H)-furanone (3), a commercially available compound, and found that treatment of 3 with 1.0 equiv of $\mathrm{NBS}$ in $\mathrm{CCl}_{4}$ under reflux in the presence of catalytic amount of benzoyl peroxide gave a mixture of three brominated compounds which were easily separated and identified as 3-bromo-4-methoxy2(5H)-furanone (4), 5-bromo-4-methoxy-2(5H)-furanone (5) and 3,5-dibromo-4-methoxy-2(5H)-furanone (6) (Scheme 1) [27]. Compound 4, which was the main component of the mixture, was isolated in $45 \%$ yield [27].

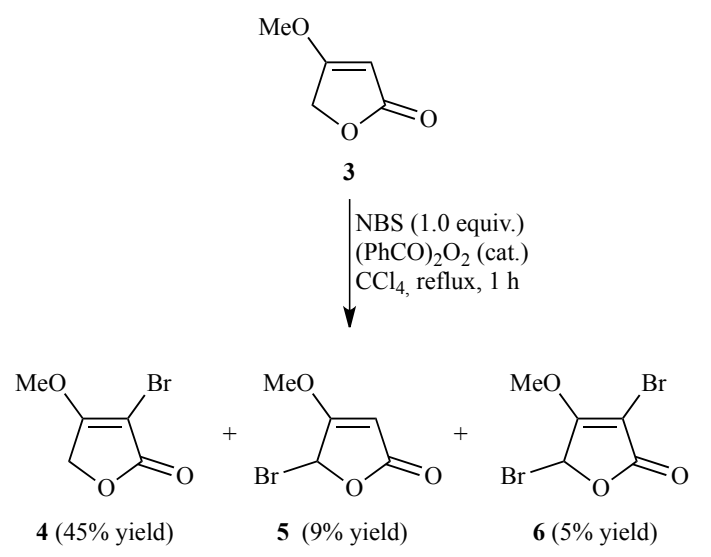


Scheme 1. Bromination of compound 3

It is interesting to note that compound $\mathbf{5}$, which was isolated in $9 \%$ yield, was used as direct precursor to the aglycone 7 (Figure 2) [27] of the antibiotic glycoside narthecide, which was isolated from Narthecium ossifragrum [28].

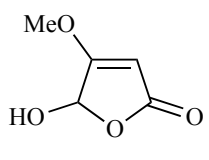

7

Figure 2. Structure of aglycone 7

In 2006, Heo and coworkers synthesized compound $\mathbf{4}$ in $80 \%$ yield via addition of bromine to $\mathbf{3}$ and subsequent $\mathrm{Et}_{3} \mathrm{~N}$-mediated elimination of hydrobromic acid (Scheme 2) [29]. The synthesis was carried out according to a protocol described in the literature for the one-pot preparation of $\alpha$-bromoenones from the corresponding enones [30].

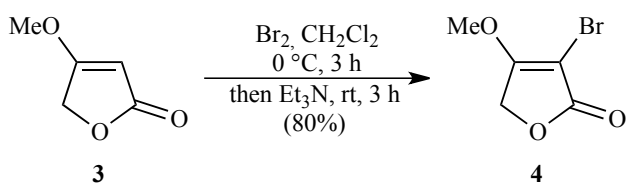

Scheme 2. High yielding synthesis of 3-bromo-4methoxy-2(5H)-furanone (4)

In 2013, Vasamsetty, Khan and Mehta synthesized 3bromo-5-methoxy-2(5H)-furanone (11) via a four-step protocol in which commercially available furfural (8) was the starting material (Scheme 3) [31].

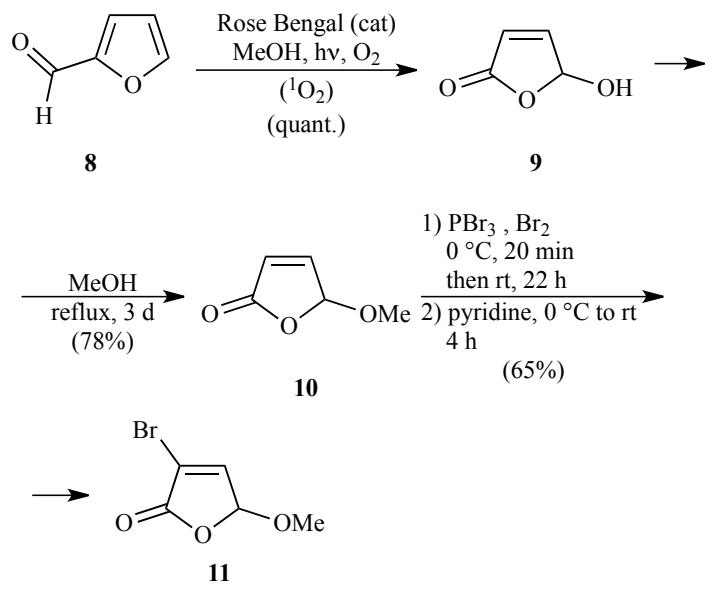

Scheme 3. Synthesis of 3-bromo-5-methoxy-2(5H)furanone (11)

Thus, Rose Bengal sensitized photo-oxidation of $\mathbf{8}$ according to the literature [32] gave 5-hydroxy-2(5H)- furanone (9) in quantitative yield, which was acetalyzed with methanol providing compound $\mathbf{1 0}$ in high yield. The subsequent bromine addition to $\mathbf{1 0}$ through a modified literature procedure [33], followed by pyridine-mediated in situ dehydrobromination of the resulting compound led to 11 in $65 \%$ yield [31].

In 2015, Zhao, Yang, Li and coworkers described that 3-bromo-2(5H)-furanone (13) could be obtained from $2(5 H)$-furanone $(12)$ in $47.6 \%$ yield by addition of bromine to 12 in $\mathrm{Et}_{2} \mathrm{O}$ under reflux, followed by $\mathrm{Et}_{3} \mathrm{~N}$-mediated dehydrobromination of the resulting adduct (Scheme 4)[34].

$$
\text { 12 }
$$

Scheme 4. Synthesis of 3-bromo-2(5H)-furanone (13)

Several years earlier, a similar procedure had been employed by de Echagüen and Ortuño for the synthesis of 3-bromo-5-methyl-2(5H)-furanone (15) from 5-methyl2(5H)-furanone (14) (Scheme 5) [35]. However, in this case, $\mathrm{CCl}_{4}$ had been used in place of $\mathrm{Et}_{2} \mathrm{O}$ as the solvent for the reaction with bromine.
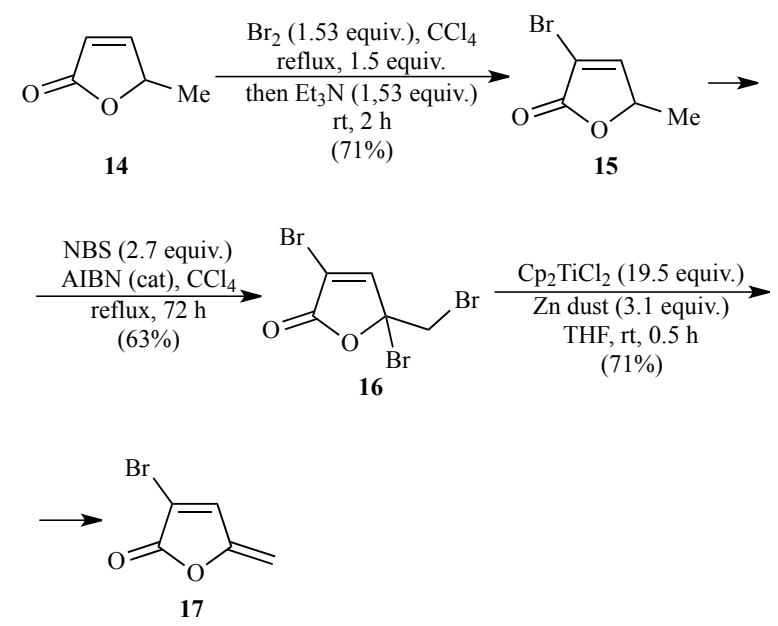

Scheme 5. Synthesis of compounds 15 and 17

Compound 15 was then employed as the starting material for a two-step synthesis of 3-bromo-5-methylene2(5H)-furanone (17) involving the AIBN-mediated reaction of 15 with 2.7 equiv of $\mathrm{NBS}$ in $\mathrm{CCl}_{4}$ under reflux and the reductive debromination of the resulting compound 16 by using zinc dust in THF in the presence of a catalytic amount of $\mathrm{Cp}_{2} \mathrm{TiCl}_{2}$ (Scheme 5) [35].

In 1990, Sánchez-Ferrando and coworkers synthesized a 1 : 1 mixture of erythro- and threo-3-bromo-5-(1hydroxyethyl)-2(5H)-furanone (21) in $20 \%$ yield by treatment of sorbic acid (18) with 2.62 equiv of NBS in water at $37{ }^{\circ} \mathrm{C}$ for $18.5 \mathrm{~h}$ (Scheme 6) [36]. These authors 
speculated that the formation of $\mathbf{2 1}$ could take place from intermediates 19 and 20 (Scheme 6) [36].<smiles>C/C=C/C=C/C(=O)O</smiles>

Scheme 6. Synthesis of 3-bromo-5-(1-hydroxyethyl)2(5H)-furanone (21)

In 2006, 3-bromo-5-hydroxy-2(5H)-furanone (23) was obtained in $78 \%$ yield by Riccio and coworkers via photooxidation of 3-bromofuran (22) in $\mathrm{CH}_{2} \mathrm{Cl}_{2}$ at $-78{ }^{\circ} \mathrm{C}$ in the presence of 2 equiv of DBU (Scheme 7) [37].

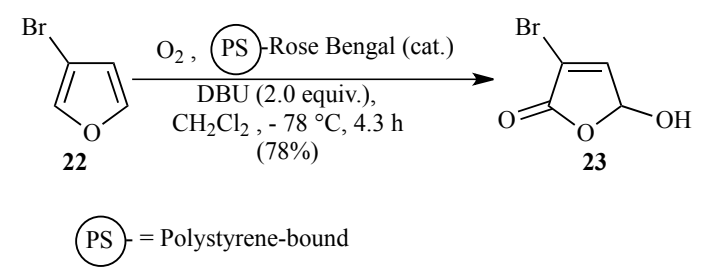

Scheme 7. Synthesis of 3-bromo-5-hydroxy-2(5H)furanone (23)

In 2008, 3-bromo-5-methyl-2(5H)-furanone (15) was also prepared in $73 \%$ yield from ynamine $\mathbf{2 4}$ and propylene oxide (25) [38] by using the method of Jacobsen [39] as shown in Scheme 8.
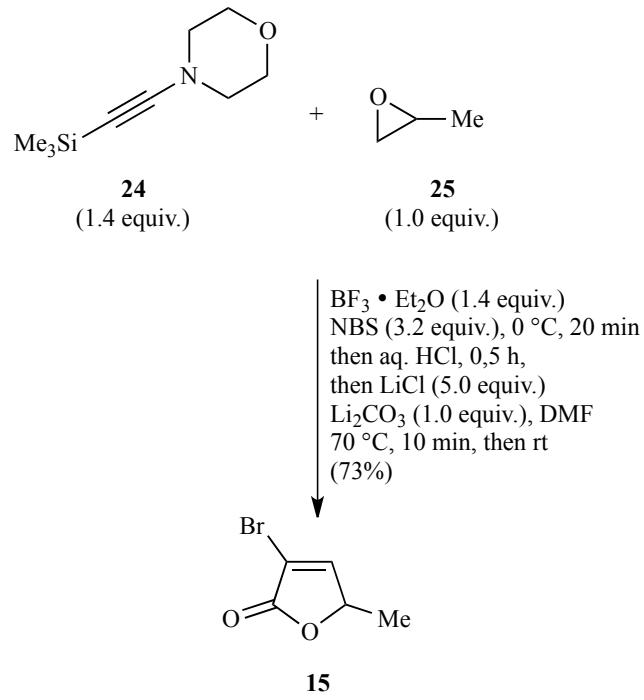

Scheme 8. Synthesis of compound 15 from ynamine 24 and propylene oxide (25)

Notably, compound 15 was also synthesized in $20-52 \%$ yield from $\alpha$-angelica lactone (26) (Figure 3) by isomerization and subsequent addition of brominedehydrobromination $[40,41]$.<smiles>CC1=CCC(=O)O1</smiles>

26

Figure 3. Structure of $\alpha$-angelica lactone (26)

In 2010, Terada and coworkers investigated the axially chiral guanidine base $(R)$-CGB-catalyzed asymmetric vinylogous aldol reaction of 3-bromo-2 $(5 H)$-furanone (13) with benzaldehyde (27) and found that treatment of 13 with 1.2 equiv of 27 in THF at $-40{ }^{\circ} \mathrm{C}$ in the presence of 5 mol\% $(R)$-CGB led to syn-3-bromo-5-(1-hydroxybenzyl)$2(5 H)$-furanone $(\mathbf{2 8})$ in $42 \%$ yield with $98 \%$ ee together with $\beta, \gamma$-unsaturated lactone 29 in $18 \%$ yield and $71 \%$ ee (Scheme 9) [42]. 
<smiles>O=Cc1ccccc1</smiles>

$$
\begin{array}{cc}
\mathbf{1 3} & \mathbf{2 7} \\
(1.0 \text { equiv. }) & (1.2 \text { equiv. })
\end{array}
$$
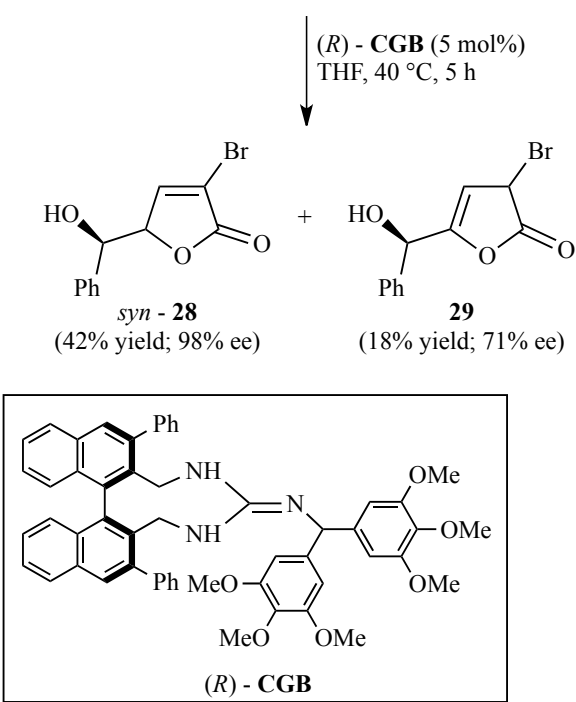

Scheme 9. Synthesis of (R)-3-bromo.5-(1hydroxybenzyl)-2(5H)-furanone $s y n-(\mathbf{2 8})$ and lactone 29

In 2000, our research group prepared 3,4-dibromo$2(5 H)$-furanone $(2)$ in $75 \%$ yield by the reaction of mucobromic acid (1) with 1.5 equiv. of $\mathrm{NaBH}_{4}$ in methanol at $0{ }^{\circ} \mathrm{C}$ for $15 \mathrm{~min}$, followed by the addition of 1.0 equiv of concd. sulfuric acid, and found that $\mathbf{2}$ was able to undergo Pd-catalyzed reaction with equimolar amounts of aryl(trialkyl)stannanes $\mathbf{3 0 a}-\mathbf{e}$ in NMP at room temperature to provide regioselectively 4-aryl-3-bromo- $2(5 H)$ furanones 31a-e in yields ranging from 58 to $76 \%$ (Scheme 10) [43]. The catalyst system that was used for the cross-coupling reactions consisted of $5 \mathrm{~mol} \%$ $\mathrm{PdCl}_{2}(\mathrm{PhCN})_{2}$ and $10 \mathrm{~mol}^{\%} \mathrm{AsPh}_{3}$ (catalyst $\left.A\right)$ or was obtained by treatment of $2.5 \mathrm{~mol} \% \mathrm{Pd}_{2}(\mathrm{dba})_{3}$ with 10

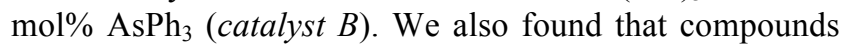
31 could be used as direct precursors to 3-unsubstituted-4aryl-2(5H)-furanones 32 (Figure 4 ), a class of compounds that, in 2001, were synthesized in excellent yields by halolactonization of 2,3-allenoic acids followed by a Suzuki-type coupling reaction with arylboronic acids [44] and, in 2009, were prepared by the reaction of diethylphosphonoacetic acid (33) with phenacyl bromides 34 (Figure 4), followed by an intramolecular HornerEmmons type cyclization [45].
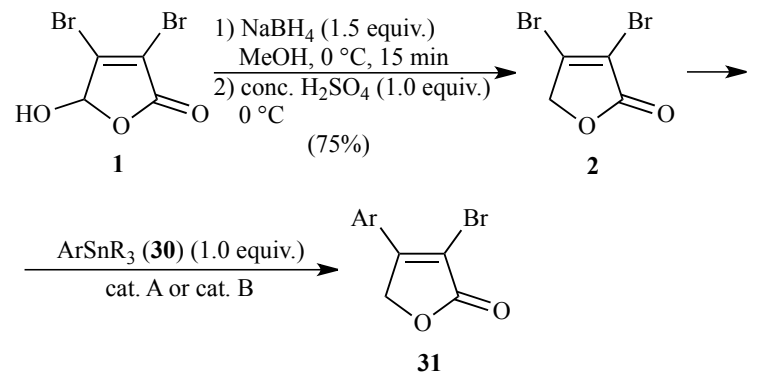

\begin{tabular}{|c|c|c|c|c|c|c|}
\hline \multirow{2}{*}{ Entry } & \multicolumn{2}{|l|}{30} & \multirow[b]{2}{*}{ - Catalyst ${ }^{(a)}$} & \multirow{2}{*}{$\begin{array}{c}\text { Reaction } \\
\text { time }(\mathrm{h})\end{array}$} & \multicolumn{2}{|c|}{ Product } \\
\hline & $\mathrm{Ar}$ & $\mathrm{R}$ & & & 31 & Yield\% \\
\hline 1 & $\mathrm{Ph}$ & $\mathrm{Bu}$ & $A$ & 93 & $31 \mathrm{a}$ & 76 \\
\hline 2 & $\mathrm{Ph}$ & $\mathrm{Me}$ & $A$ & 39 & $31 \mathrm{a}$ & 70 \\
\hline 3 & $\mathrm{Ph}$ & $\mathrm{Bu}$ & $B$ & 94 & $31 a$ & 67 \\
\hline 4 & $4-\mathrm{MeSC}_{6} \mathrm{H}_{4}$ & $\mathrm{Me}$ & $B$ & 22 & $31 b$ & 59 \\
\hline 5 & $4-\mathrm{MeOC}_{6} \mathrm{H}_{4}$ & $\mathrm{Bu}$ & $B$ & 89 & $31 \mathrm{c}$ & 68 \\
\hline 6 & $3-\mathrm{FC}_{6} \mathrm{H}_{4}$ & $\mathrm{Bu}$ & $B$ & 89 & 31d & 58 \\
\hline 7 & 4- $\mathrm{MeC}_{6} \mathrm{H}_{4}$ & $\mathrm{Bu}$ & B & 112 & $31 \mathrm{e}$ & 73 \\
\hline
\end{tabular}

Scheme 10. Synthesis of 3,4-dibromo-2(5H)-furanone (2) and its regioselective Pd-catalyzed monoarylation reaction with aryl(trialkyl)stannanes<smiles>O=C1C=C([17F])CO1</smiles>

32<smiles>CCOP(=O)(CC(=O)O)OCC</smiles>

33<smiles>O=C(Br)CBr</smiles>

34
Figure 4. Structures of compounds 32-34

In a typical example, we found that treatment of 31c with 4.0 equiv of zinc powder, which was activated with $3.7 \mathrm{~mol} \%$ 1,2-dibromoethane and then with $3.0 \mathrm{~mol} \%$ $\mathrm{Me}_{3} \mathrm{SiCl}$ [46] in $\mathrm{THF}$ at $65{ }^{\circ} \mathrm{C}$ for $89.5 \mathrm{~h}$ followed by hydrolysis gave 4-(4-methoxyphenyl)-2( $5 H)$-furanone (32c) in 74\% yield (Scheme 11) [43]. It is worth noting that compound 32c had previously been employed as a precursor to rubrolide C (35) [47], a metabolite of the colonial tunicates Ritterella rubra [48] and Synoicum blochmanni [49], which was shown to exhibit antibacterial activity against Staphylococcus aureous (MIC $=11$ $\mu \mathrm{g} /$ disc) and Bacillus subtilis (MIC $=11 \mu g / d i s c)$ and moderate but selective inhibition of protein phosphatases 1 and 2A [48]. 

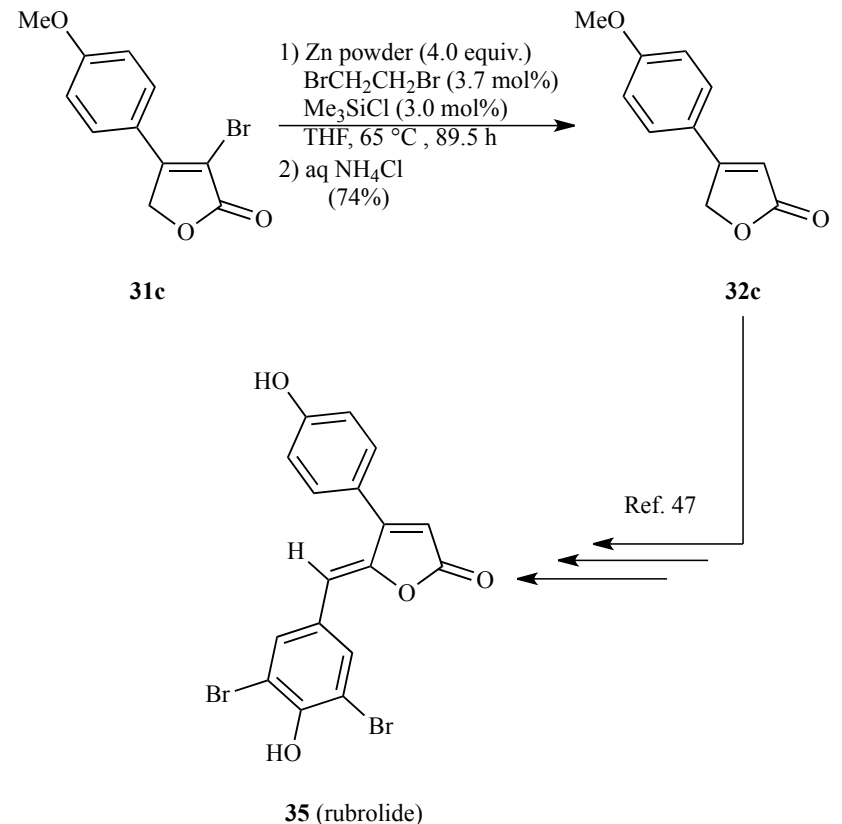

Scheme 11. Synthesis of compound $32 \mathrm{c}$, a precursor to rubrolide $\mathrm{C}(\mathbf{3 5})$

In 2001, we developed an unprecedented, general and efficient procedure for the regioselective synthesis of 4alkyl-3-bromo-2 $(5 H)$-furanones 37 [50]. We found that the reaction of 3,4-dibromo-2(5H)-furanone (2) with 1.1 equiv of alkylboronic acids 36 in THF under reflux for 18-23 h in the presence of 3.0 equiv of $\mathrm{Ag}_{2} \mathrm{O}, 5 \mathrm{~mol} \% \mathrm{PdCl}_{2}\left(\mathrm{MeCN}_{2}\right.$ and $20 \mathrm{~mol} \% \mathrm{AsPh}_{3}$ proceeded regioselectively providing the cross-coupling products $\mathbf{3 7}$ in yields ranging from 69 to $79 \%$ (Scheme 12) [50]. Notably, the cross coupling reaction appeared suitable to prepare multigram quantities of compounds 37 and in all cases examined it did not provide any trace of symmetrical 3,4-dialkyl-2(5H)furanones [50].

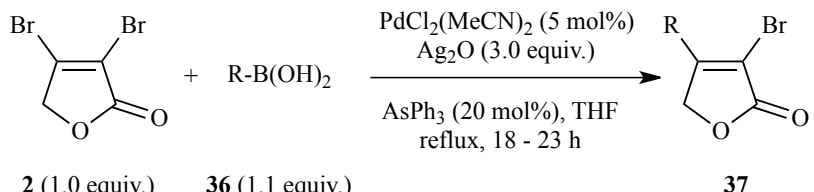

\begin{tabular}{lccc}
\hline 37 & $\mathrm{R}$ & Reaction time (h) & Yield\% \\
\hline 37a & $n$-Oct & 22 & 71 \\
37b & $t$-BuO(CH$)_{6}$ & 23 & 70 \\
37c & $t$-BuOCH$(\mathrm{Me})\left(\mathrm{CH}_{2}\right)_{5}$ & 23 & 69 \\
37d & $n-\mathrm{Bu}$ & 18 & 79 \\
\hline
\end{tabular}

Scheme 12. Regioselective synthesis of 4-alkyl-3bromo-2 $(5 H)$-furanones 37

One year later, as part of an effort to explore the use of 3,4-dibromo-2 $(5 H)$-furanone (2) for the selective synthesis of nostoclides I (38a) and II (38b) (Figure 5), which are a pair of cytotoxic compounds produced by a cyanobacterium Nostoc sp. [51], we planned to prepare 3-
bromo-4-isopropyl-2(5H)-furanone (37e) (Figure 4) as a useful precursor to these natural products [52].<smiles>[Y]c1cc(Cl)cc(/C=C2\OC(=O)C(Cc3ccccc3)=C2C(C)C#N)c1</smiles><smiles>[Y9]C([Y4])C1=C(Br)C(=O)OC1</smiles>

38a $: \mathrm{Y}=\mathrm{Cl}$ (nostoclide $\mathrm{I})$ 38b : $\mathrm{Y}=\mathrm{H}$ (nostoclide II)

Figure 5. Structures of compounds $38 \mathrm{a}, 38 \mathrm{~b}$ and $37 \mathrm{e}$

Unfortunately, the reaction of 2 with 1.1 equiv of isopropylboronic acid under the experimental conditions developed to prepare compounds 37a-d [50] did not occur at all. Nevertheless, compound $\mathbf{3 7} \mathbf{e}$ could be synthesized in $74 \%$ overall yield by the two-step route shown in Scheme $13[52]$.

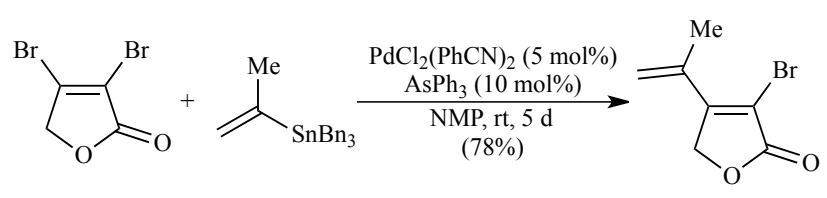

2 (1.0 equiv.) $\mathbf{3 9}$ (1.1 equiv) 40

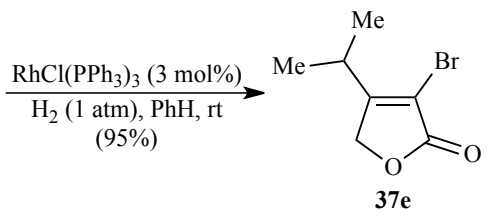

Scheme 13. Two-step synthesis of 3-bromo-4isopropyl-2(5H)-furanone (37e)

Still in 2002, Zhang and coworkers described the preparation of 3,4-dibromo-2 $(5 H)$-furanone (2) in $57 \%$ yield by treatment of mucobromic acid (1) with 1.5 equiv of sodium triacetoxyborohydride in $\mathrm{CHCl}_{3}$ at $0-5{ }^{\circ} \mathrm{C}$ followed by addition of acetic acid [53]. Compound 2 was then reacted with 2.0 equiv of 4-(methylthio)phenylboronic acid (41) in a $1: 1$ mixture of toluene and water at 20-25 ${ }^{\circ} \mathrm{C}$ for 3 days in the presence of $5 \mathrm{~mol} \% \mathrm{PdCl}_{2}\left(\mathrm{PPh}_{3}\right)_{2}, 5$ mol\% $\mathrm{BnEt}_{3} \mathrm{NCl}$ and 2.67 equiv of $\mathrm{CsF}$ producing 3bromo-4-(4-methylthiophenyl)-2(5H)-furanone (31b) in $75-91 \%$ yield (Scheme 14). Compound 31b was then used as an advanced precursor to Vioxx ${ }^{\circledR}(\mathbf{4 2})$ (Scheme 14), an anti-inflammatory drug launched by Merck, which, however, in 2004, was withdrawn from the market worldwide. 

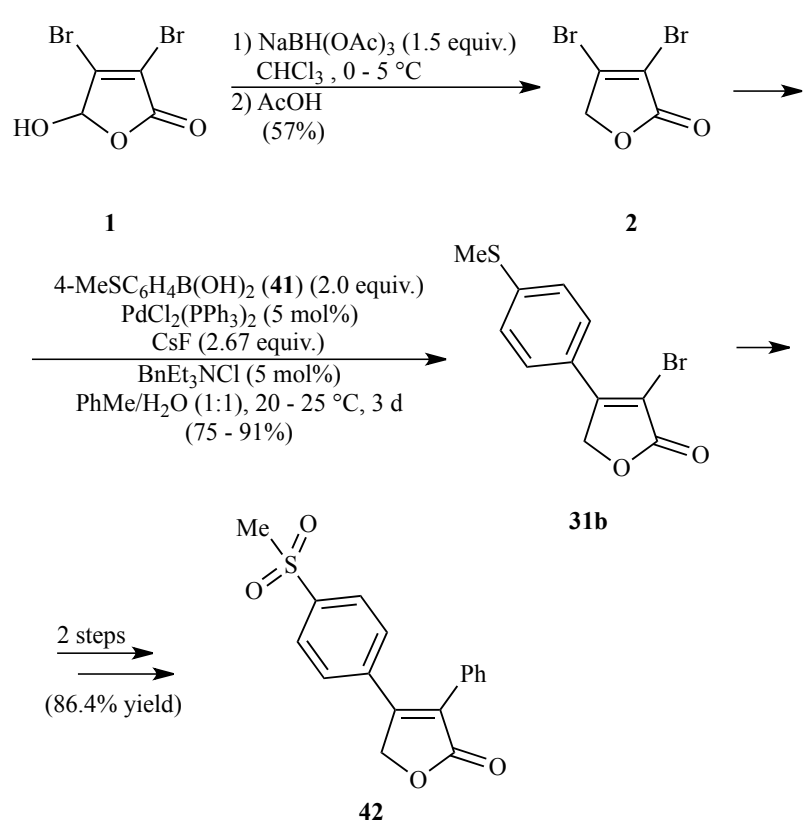

Scheme 14. Synthesis of compound 31b, an advanced precursor to $\operatorname{Vioxx}{ }^{\circledR}(\mathbf{4 2})$

In 2014, 4-aryl-3-bromo-2(5H)-furanones 44a-c were synthesized in modest yields by Barbosa and coworkers through a $\mathrm{PdCl}_{2}(\mathrm{PhCN})_{2} / \mathrm{AsPh}_{3}{ }^{-}$catalyzed Suzuki-Miyaura reaction of 2 with 4-arylboronic acids $43 \mathbf{a}-\mathbf{c}$ in THF at 65 ${ }^{\circ} \mathrm{C}$ in which $\mathrm{Ag}_{2} \mathrm{O}$ was used as the base (Scheme 15) [54].<smiles>[R]c1ccc(OC)c([B]O)c1</smiles>

$$
\text { 2(1.0 equiv.) } \begin{aligned}
& 43 \text { a-c } \\
& \mathrm{PdCl}_{2}(\mathrm{PhCN})_{2}(5.1 \mathrm{~mol} \%) \\
& \mathrm{AsPh}_{3}(20.1 \mathrm{~mol} \%) \\
& \mathrm{Ag}_{2} \mathrm{O}(3.0 \text { equiv. }) \\
& \mathrm{THF}, 6{ }^{\circ} \mathrm{C}, 24 \mathrm{~h}
\end{aligned}
$$

Scheme 15. Synthesis of 4-aryl-3-bromo-2( $5 H)$-furanones 45a-c

More recently, Wang and coworkers developed an efficient protocol for the synthesis of 5-alkoxy-4-aryl-3bromo-2(5H)-furanones 47 [55]. It involved the
$\mathrm{PdCl}_{2} / \mathrm{PPh}_{3}$-catalyzed desulfitative regioselective arylation of 5-alkoxy-3,4-dibromo-2(5H)-furanones $\mathbf{4 5}$ with sodium arylsulfinates $\mathbf{4 6}$ as aryl source (Scheme 16). The reaction was carried out in toluene under reflux using $\mathrm{NaHCO}_{3}$ as the base providing compounds $\mathbf{4 7}$ in yields ranging from 62 to $82 \%$ [55].
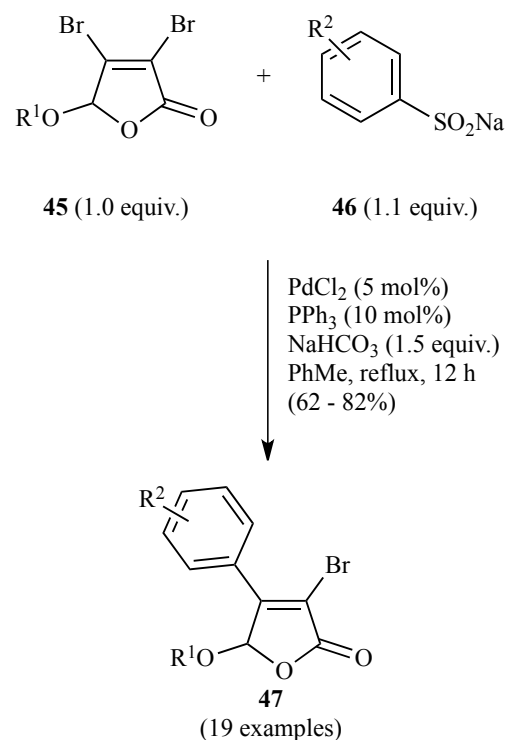

Scheme 16. Synthesis of 5-alkoxy-4-aryl-3-bromo2(5H)-furanones 47

Still in 2015, $\mathrm{Hu}$ and coworkers demonstrated that 4arylmethyl-3-bromo-2 $(5 H)$-furanones 49 could be prepared in satisfactory yields by reacting 3,4-dibromo-2(5H)furanone (2) with 1.2 equiv of potassium arylmethyltrifluoroborates 48 in a 1: 1 mixture of toluene and water at $70{ }^{\circ} \mathrm{C}$ for $12 \mathrm{~h}$ in the presence of $5 \mathrm{~mol} \%$ $\mathrm{PdCl}_{2}$ (dppf) and 2.0 equiv of $\mathrm{K}_{2} \mathrm{CO}_{3}$ (Scheme 17) [56]. The potassium arylmethyltrifluoroborates that were not commercially available were prepared prepared according to a literature procedure [57].

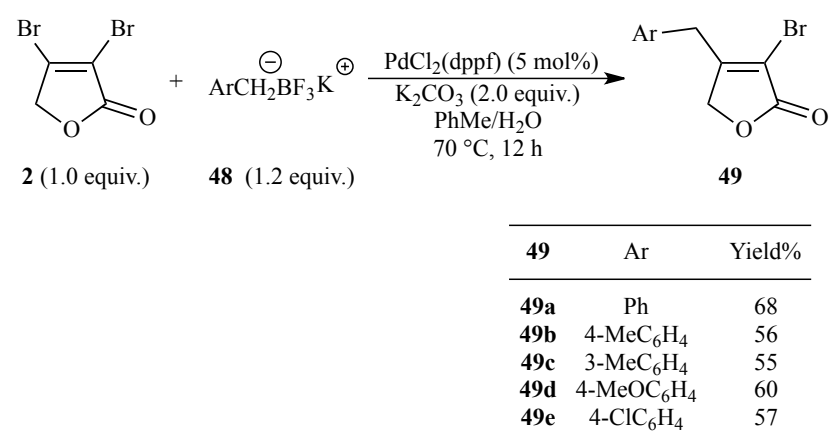

Scheme 17. Regioselective synthesis of 4-arylmethyl-3bromo-2(5H)-furanones 49

It deserves to be noted that compound 49a was used as a precursor of gymnoascolide (50) (Figure 6) [56], a butenolide isolated from the Australian soil ascomycete Gymnoascus reessii [58], as well as of eutypoid (51) 
(Figure 6), a metabolite of the mangrove fungus Eutypa sp. (\# 424) [59.]
50 (gymnoascolide A)<smiles>O=C1OCC(Cc2ccccc2)=C1c1ccccc1</smiles>

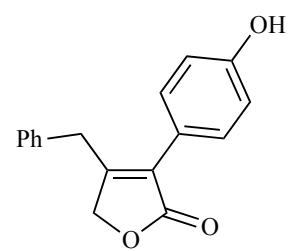

51 (eutypoid A)
Figure 6. Structures of naturally-occurring compounds 50 and 51

In the same year, Kimura, Satoh and coworkers described a three-step synthesis of 3-bromo-4-(2phenylethyl)-2(5H)-furanone (57) in which bromomethyl $p$-tolyl sulfoxide (52) was the starting material (Scheme 18) [60].

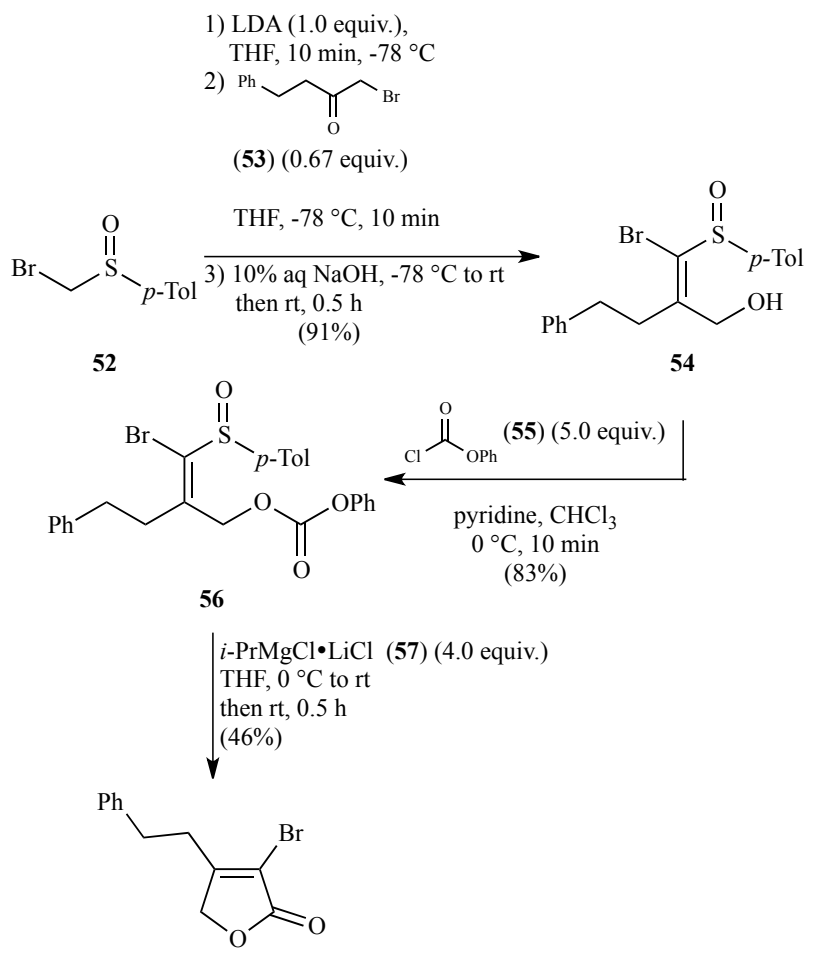

58

Scheme 18. Three-step synthesis of compound $\mathbf{5 7}$

The synthesis began with the reaction of $\mathbf{5 2}$ with LDA in THF at $-78{ }^{\circ} \mathrm{C}$ and addition of 1-bromo-4-phenylbutan2-one (53) to the resulting lithium derivative, followed by basification with aqueous $\mathrm{NaOH}$, which gave 1-bromo-3hydroxyprop-1-enyl $p$-tolyl sulfoxide (54) in 91\% yield. The subsequent reaction of $\mathbf{5 4}$ with phenyl chloroformate (55) in $\mathrm{CHCl}_{3}$ in the presence of pyridine gave sulfoxide 56 in $83 \%$ yield. Finally, the nucleophilic cyclization of the magnesium alkylidene carbenoid generated from 56 and $i$ -
PrMgCl$\cdot \mathrm{LiCl}$ (57) provided compound 58 in $46 \%$ yield (Scheme 18) [60].

Six years earlier, as part of a study on the synthesis of brominated furanones, which are quorum quenching compounds that inhibit biofilm formation and the expression of virulence in in vitro and in vivo models, Kumar and coworkers had synthesized 3-bromo-5-(2methylpropylidene)-2(5H)-furanone (64a) and 3-bromo-5(2,2-dimethylpropylidene)-2(5H)-furanone (64b) via a multi-step route in which 2-pentanones 59a and 59b, respectively, were used as starting materials (Scheme 19) [61]. The first step of the developed protocol involved the regioselective condensation of ketones 59a and 59b with glyoxylic acid (60). Addition of bromine to the resulting compounds $61 \mathbf{a}$ and $\mathbf{6 1 b}$, respectively, provided the dibromo derivatives $\mathbf{6 2 a}$ and $\mathbf{6 2} \mathbf{b}$, respectively, which underwent dehydration by treatment with $\mathrm{P}_{2} \mathrm{O}_{5}$ leading to 3,4-dibromodihydrofuran-2-ones 63a and $\mathbf{6 3 b}$, respectively, which unfortunately proved to be difficult to isolate and purify.
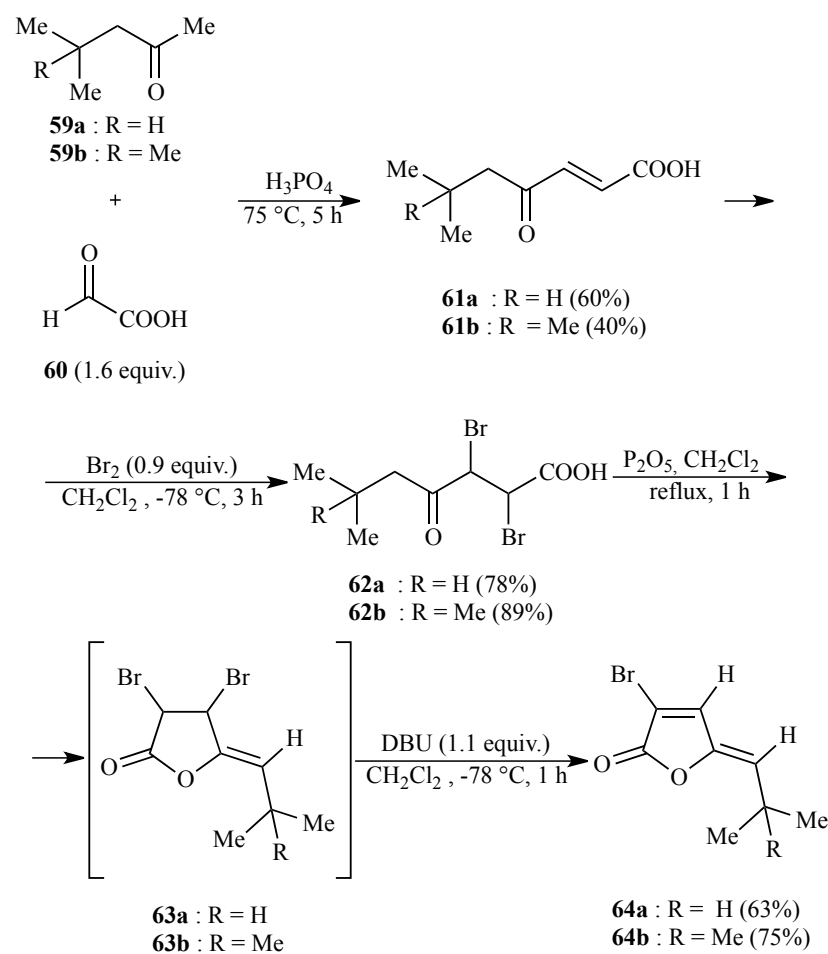

Scheme 19. Regioselective synthesis of 3-bromo-2(5H)furanones 64a and 64b

Therefore, these crude products were reacted with DBU in $\mathrm{CHCl}_{3}$ at $-78^{\circ} \mathrm{C}$ to give the target compounds $64 \mathbf{a}$ and 64b in $29.5 \%$ and $26.6 \%$ overall yield, respectively, based on the starting ketones $\mathbf{5 9 a}$ and $\mathbf{5 9 b}$, respectively [61]. The biological activity of compounds $64 a$ and $64 \mathbf{b}$ however was not evaluated.

Over the past 20 years, significant attention has also been paid to the synthesis of enantiomerically pure 5alkoxy-3-bromo-2(5H)-furanones. In 1995, Chen and 
coworkers prepared enantiomerically pure 5-( $l$ menthyloxy)-3,4-dibromo-2(5H)-furanone (66a) by acetalyzation of mucobromic acid (1) with $l$-menthol (65) in the presence of a catalytic amount of concd. sulfuric acid (Scheme 20) [62]. Crystallization of the resulting epimeric mixture allowed to obtain enantiomerically pure 66a in $33 \%$ yield. The subsequent tandem Michael additionelimination reaction of $\mathbf{6 6 a}$ with thiols or amines then yielded 5-alkoxy-3-bromo-2(5H)-furanones $\mathbf{6 7}$ and $\mathbf{6 8}$ respectively, in good yields with de $>98 \%$ (Scheme 20) [62].

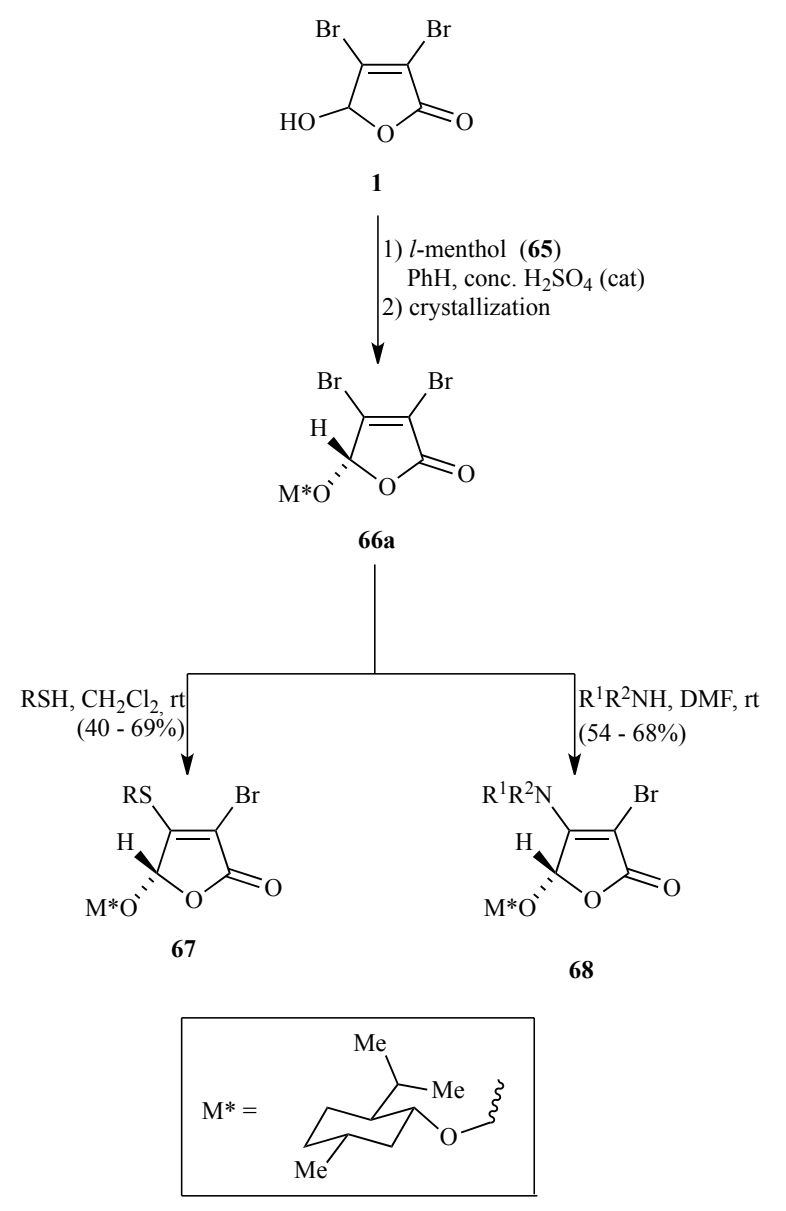

Scheme 20. Synthesis of chiral 5-alkoxy-3-bromo2(5H)-furanones 67 and 68

In 1998, Huang and Chen synthesized $5(R)-[(1 R, 2 S, 5 R)-$ (-)-menthyloxy]-3-bromo-2(5H)-furanone (70a) in $46 \%$ yield with de $>98 \%$ by crystallization of an epimeric mixture of 5-(l-menthyloxy)-3-bromo-2 $(5 H)$-furanone (70), which was obtained via addition of bromine to an epimeric mixture of 5-(l-menthyloxy)-2(5H)-furanone (69) followed by pyridine-mediated elimination of hydrogen bromide (Scheme 21) [63].

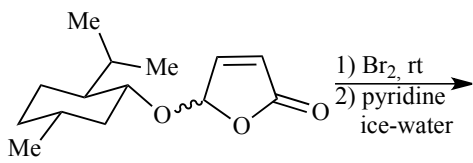

69<smiles>CC(C)CC(OC1C=C(Br)C(=O)O1)C(C)C</smiles>

70

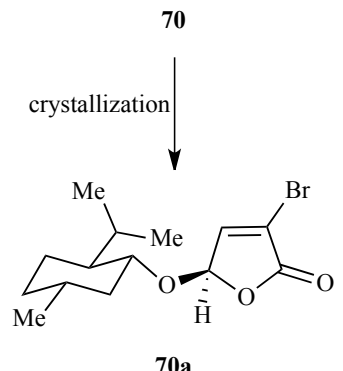

Scheme 21. Synthesis of $5(R)-[(1 R, 2 S, 5 R)-(-)-$ menthyloxy]-3-bromo-2(5H)-furanone (70a)

In 2009, Li, Shao and coworkers synthesized a series of chiral 2,5-disubstituted 1,3,4-thiadiazoles 72 possessing a $2(5 H)$-furanone moiety according to the procedure depicted in Scheme 22 [64]. Specifically, acetalyzation of mucobromic acid (1) with (-)-menthol [63] and (+)borneol [65] followed by separation of the resulting diastereomers allowed to obtain enantiomerically pure compounds 66a and 66b respectively. The subsequent tandem Michael addition-elimination reactions of these compounds with 2-mercapto-1,3,4-thiadiazoles 71 then gave compounds 72a-l in good to excellent yields (Scheme 22) [64]. 
<smiles>[R]c1nnc(S)s1</smiles>

66a : $\mathrm{M}^{*}=1$-menthyl 66b : $\mathbf{M}^{*}=$ bornyl

71

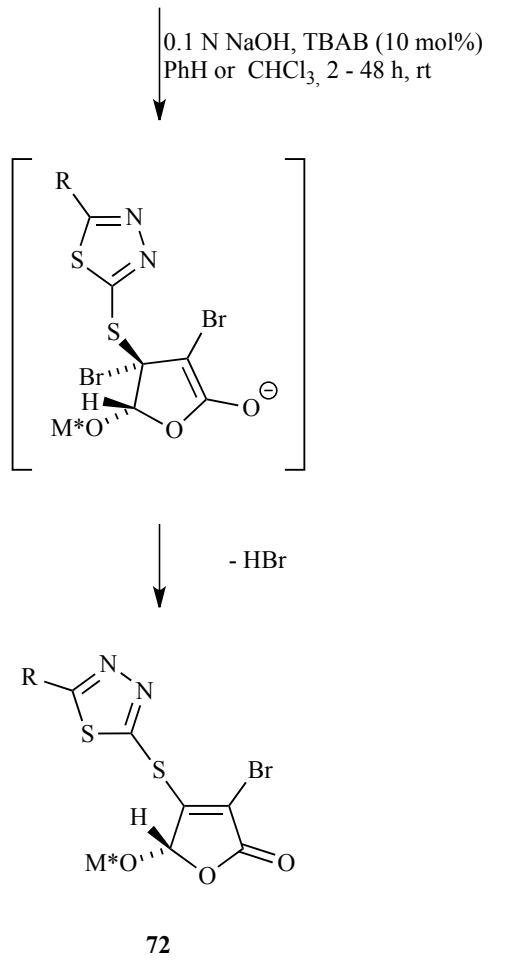

\begin{tabular}{cccc}
\hline $\mathbf{7 2}$ & $\mathrm{M}^{*}$ & $\mathrm{R}$ & Yield\% \\
\hline $\mathbf{7 2 a}$ & 1-menthyl & $\mathrm{Ph}$ & 98 \\
$\mathbf{7 2 b}$ & 1-menthyl & 4- $\mathrm{ClC}_{6} \mathrm{H}_{4}$ & 95 \\
$\mathbf{7 2 c}$ & 1-menthyl & 2- $\mathrm{HOC}_{6} \mathrm{H}_{4}$ & 96 \\
$\mathbf{7 2 d}$ & 1-menthyl & 4- $\mathrm{HOC}_{6} \mathrm{H}_{4}$ & 66 \\
$\mathbf{7 2 e}$ & 1-menthyl & 4- $\left(\mathrm{NO}_{2}\right) \mathrm{C}_{6} \mathrm{H}_{4}$ & 83 \\
$\mathbf{7 2 f}$ & 1-menthyl & 4- $\mathrm{MeOC}_{6} \mathrm{H}_{4}$ & 92 \\
$\mathbf{7 2 g}$ & 1-menthyl & 2-furyl & 75 \\
$\mathbf{7 2 h}$ & 1-menthyl & 4-pyridyl & 83 \\
$\mathbf{7 2 i}$ & 1-menthyl & 3-pyridyl & 89 \\
$\mathbf{7 2 j}$ & bornyl & 2-furyl & 60 \\
$\mathbf{7 2 k}$ & bornyl & 4-pyridyl & 69 \\
$\mathbf{7 2 l}$ & bornyl & 3-pyridyl & 69
\end{tabular}

Scheme 22. Synthesis of compounds 72 a-l

It was then discovered that all compounds 72a-l exhibited anticancer activity against human epitheloid cervix carcinoma (HeLa) cells and that compound 72e possessed the best inhibitory activity with an $\mathrm{IC}_{50}$ of 0.9 $\mu \mathrm{M}[64]$.

In 2013, a series of 5-alkoxy-4-amino-3-bromo-2(5H)furanones of general formula $\mathbf{7 4}$ which included chiral derivatives were synthesized in modest to good yields by Fan, $\mathrm{Li}$ and coworkers using a one-pot protocol involving the regioselective transalkylation of $N$-methyl tertiary amines 73 with 5-alkoxy-3,4-dibromo-2(5H)-furanones 45a, 66a and 66b [66]. As shown in Scheme 23, the reactions generally occurred in $\mathrm{CH}_{2} \mathrm{Cl}_{2}$ or DMSO at room temperature producing compounds $\mathbf{7 4 a - j}$ in yields ranging from 35 to $87 \%$ [66]. Notably, compound $74 \mathrm{~b}$ in which $\mathrm{R}^{1}$ $=$ menthyl and $\mathrm{R}^{2}=$ Me was found to posses a significant anticancer activity against $\mathrm{HeLa}$ cell lines $\left(\mathrm{IC}_{50}=0.19\right.$ $\mu \mathrm{M} / \mathrm{L})[66]$.

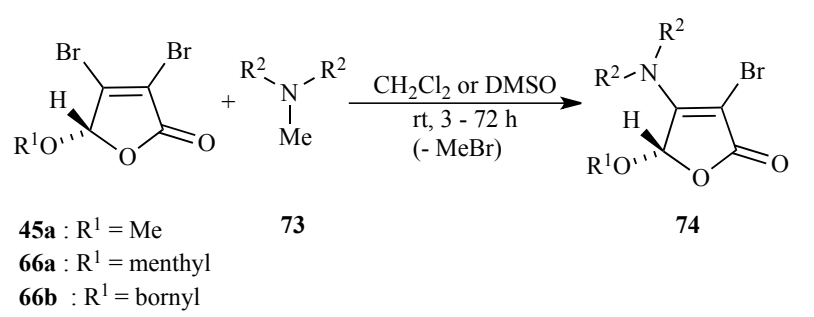

\begin{tabular}{|c|c|c|c|c|c|}
\hline 74 & $\mathrm{R}^{1}$ & $\mathrm{R}^{2}$ & Solvent & $\begin{array}{c}\text { Reaction } \\
\text { time }(\mathrm{h})\end{array}$ & Yield $\%$ \\
\hline $74 a$ & $\mathrm{Me}$ & $\mathrm{Me}$ & $\mathrm{CH}_{2} \mathrm{Cl}_{2}$ & 3 & 87 \\
\hline $74 \mathrm{~b}$ & menthyl & $\mathrm{Me}$ & $\mathrm{CH}_{2} \mathrm{Cl}_{2}$ & 3 & 86 \\
\hline $74 \mathrm{c}$ & bornyl & $\mathrm{Me}$ & $\mathrm{CH}_{2} \mathrm{Cl}_{2}$ & 3 & 84 \\
\hline 74d & $\mathrm{Me}$ & $\left(\mathrm{CH}_{2}\right)_{5}$ & DMSO & 24 & 39 \\
\hline $74 e^{(*)}$ & menthyl & $\left(\mathrm{CH}_{2}\right)_{5}$ & DMSO & 24 & 43 \\
\hline $74 f$ & bornyl & $\left(\mathrm{CH}_{2}\right)_{5}$ & DMSO & 24 & 45 \\
\hline $74 \mathrm{~g}$ & $\mathrm{Me}$ & $\left(\mathrm{CH}_{2}\right)_{4}$ & DMSO & 3 & 53 \\
\hline $74 \mathrm{~h}$ & menthyl & $\left(\mathrm{CH}_{2}\right)_{4}$ & DMSO & 9 & 63 \\
\hline $74 i$ & $\mathrm{Me}$ & $\left(\mathrm{CH}_{2}\right) \mathrm{O}\left(\mathrm{CH}_{2}\right)$ & DMSO & 26 & 55 \\
\hline $\mathbf{7 4} \mathbf{j}^{(*)}$ & menthyl & $\left(\mathrm{CH}_{2}\right) \mathrm{O}\left(\mathrm{CH}_{2}\right)$ & DMSO & 72 & 72 \\
\hline
\end{tabular}

Scheme 23. Synthesis of 5-alkoxy-4-amino-3-bromo2(5H)-furanones $\mathbf{7 4 a - j}$

Two years earlier, Cunha and coworkers had reported that a variety of 4-amino-3-bromo-2 $(5 H)$-furanones of general formula 76 could be obtained by treatment of 3,4dibromo-2 $(5 H)$-furanone (2) with primary and secondary amines 75 at room temperature (Scheme 24) [67]. The reactions were generally carried out by treatment of $\mathbf{2}$ with 2.0 equiv of amines $\mathbf{7 5}$ in methanol providing compounds 76 in yields ranging from 23 to $92 \%$ but, in some cases, high yields of compounds $\mathbf{7 6}$ were obtained by the reaction of $\mathbf{2}$ with 1.0 equiv of $\mathbf{7 5}$ and 1.0 equiv of $\mathrm{NaHCO}_{3}$ [67].

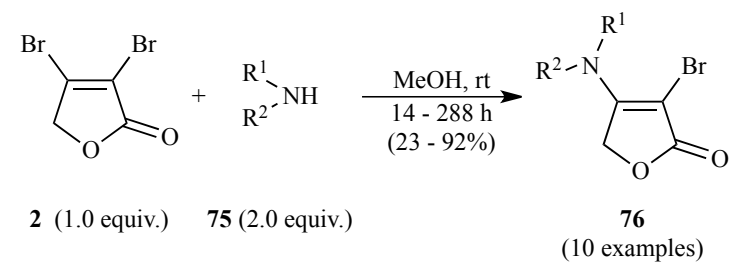

Scheme 24. Synthesis of 4-amino-3-bromo-2(5H)furanones 76

It was found that para-substituted anilines afforded generally better yields of compounds 76 than orthosubstituted ones and that their reactions occurred in shorter times [67]. 
In 2012, Wang and coworkers synthesized 5-alkoxy-4dialkylamino-3-bromo-2(5H)-furanones $\mathbf{7 4 k}, 741$ and $\mathbf{7 4 m}$ in satisfactory yields by regioselective reaction of 3,4dibromo-5-menthyloxy-2(5H)-furanone (66a) with diethyldi- $n$-propyl- and diisopropylamine, respectively, in THF at room temperature using KF as the base (Scheme 25, eq. a) [68].

(a)

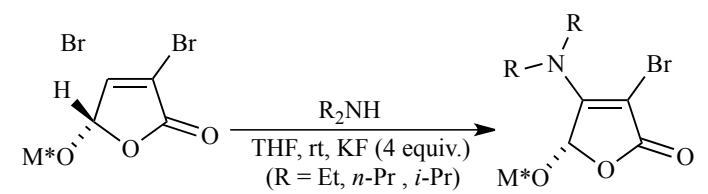

(b)
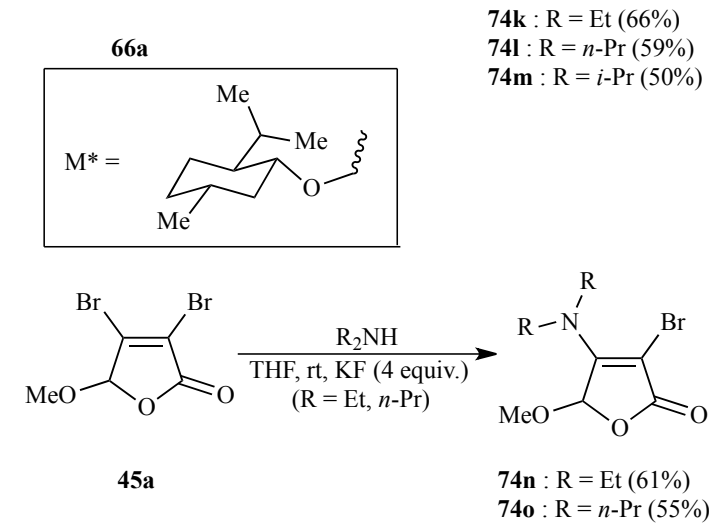

Scheme 25. Synthesis of 5-alkoxy-4-dialkylamino-3bromo-2 $(5 H)$-furanones $\mathbf{7 4 k - 0}$

Furthermore, compounds 74n and 74o were prepared in 61 and 55\% yield respectively, by tandem Michael addition-elimination reactions of 3,4-dibromo-5-methoxy$2(5 H)$-furanone $(\mathbf{4 5 a})$ with diethyl- and di- $n$-propylamine, respectively (Scheme 25, eq. b) [68]. However, the reaction between $\mathbf{4 5 a}$ and diisopropylamine in THF at room temperature in the presence of $\mathrm{KF}$, unexpectedly, gave methyl (E)-2-bromo-4-(diispropylamino)-4-oxobut-2enoate (77) in 51\% yield (Scheme 26) [68].

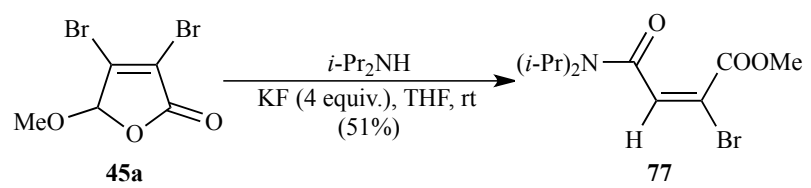

Scheme 26. Synthesis of compound 77 from 45a and diisopropylamine

Wang and coworkers also investigated the bioactivity of compounds $\mathbf{7 4}$ on adenocarcinoma human alveolar basal epithelial (A549) cells in vitro and found that some of these compounds had anticancer activity and that their inhibition activity increased with sample concentration. Interestingly, menthyloxy and methoxy substituents at position 5 had not influence on the inhibition [68].
One year later, Wang and coworkers synthesized twenty three 5-alkoxy-4-amino-3-bromo-2(5H)-furanones 79 containing aryl rings by treatment of 5-alkoxy-3,4dibromo-2(5H)-furanones $\mathbf{4 5 a}$ and $\mathbf{4 5} \mathbf{b}$ with primary amines $\mathbf{7 8}$ bearing aryl functionality in THF at room temperature or $40{ }^{\circ} \mathrm{C}$ using $\mathrm{KF}$ as the base (Scheme 27) [69]. The resulting tandem Michael addition-elimination reactions provided compounds 79 in $21-86 \%$ yield (mostly over $64 \%$ ) [69].

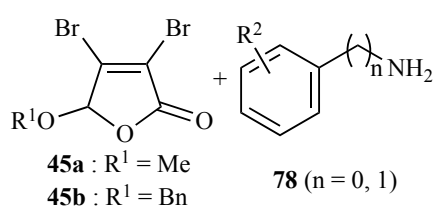

$$
\mid \begin{aligned}
& \mathrm{KF}(4.0 \text { equiv. }), \\
& \mathrm{THF}, \mathrm{rt} \text { or } 40^{\circ} \mathrm{C}, \\
& 26-120 \mathrm{~h} \\
& (21-86 \%)
\end{aligned}
$$<smiles>[R]c1cccc(C=NC2=C(Br)C(=O)OC2[R20])c1</smiles>

79

(23 examples)

Scheme 27. Synthesis of 5-alkoxy-4-amino-3-bromo2(5H)-furanones 79

In the last two decades, significant attention has also been devoted to the synthesis of (Z)-3-bromo-5-ylidene2(5H)-furanones 80 (Figure 7).<smiles>[R]C=C1OC(=O)C(Br)=C1[R]</smiles>

80

Figure 7. Structure of compounds $\mathbf{8 0}$

In 1998, our research group described the synthesis of compounds 80a-d via the route outlined in Scheme 28 [69]. In particular, according to the general procedure which we had previously developed for the regioselective and stereospecific monoarylation, monoalkynylation and monoalkylation of stereodefined 2,3-dibromo-2-alkenoates [70-72], stereoisomerically pure compounds 81a and 81b were reacted with 1.3 equiv of alkynylzinc chlorides $\mathbf{8 2} \mathbf{a}$, 82b and 82c in THF at $0-20{ }^{\circ} \mathrm{C}$ in the presence of $5 \mathrm{~mol} \%$ $\mathrm{Pd}\left(\mathrm{PPh}_{3}\right)_{4}$ to give stereoisomerically pure compounds 83ad in yields ranging from 49 to $80 \%$. 
<smiles>[R]C#C[Cr+]Br</smiles>

$$
\begin{array}{ll}
\text { 81a }: R^{1}=H & \text { 82a }: R^{2}=\mathrm{Ph} \\
\text { 81b }: R^{1}=\mathrm{Me} & \text { 82b }: \mathrm{R}^{2}=4-\mathrm{MeC}_{6} \mathrm{H}_{4} \\
& \text { 82c }: \mathrm{R}^{2}=n-\mathrm{Bu}
\end{array}
$$

$\mathrm{Pd}\left(\mathrm{PPh}_{3}\right)_{4}(5 \mathrm{~mol} \%)$ THF, $0-20^{\circ} \mathrm{C}$<smiles>[R]C#CC([R])=C(Br)OCC</smiles>

83a $: \mathrm{R}^{1}=\mathrm{H} ; \mathrm{R}^{2}=\mathrm{Ph}(64 \%)$

83b $: \mathrm{R}^{1}=\mathrm{H} ; \mathrm{R}^{2}=4-\mathrm{MeC}_{6} \mathrm{H}_{4}(68 \%)$

83c $: \mathrm{R}^{1}=\mathrm{H} ; \mathrm{R}^{2}=n-\mathrm{Bu}(80 \%)$

83d $: \mathrm{R}^{1}=\mathrm{Me} ; \mathrm{R}^{2}=n-\mathrm{Bu}(49 \%)$

$$
\begin{aligned}
& \text { 1) } 1 \mathrm{~N} \mathrm{LiOH}, \mathrm{THF}, 2{ }^{\circ} \mathrm{C} \\
& \text { 2) } \mathrm{H}_{3} \mathrm{O}^{+} \\
& \text {3) Hermann's palladacycle ( } 5 \mathrm{~mol} \%) \\
& \mathrm{PhMe}, 110^{\circ} \mathrm{C}, 16-24 \mathrm{~h} \\
& \text { or (for } 83 \mathrm{~d}) \mathrm{AgNO}_{2}(20 \mathrm{~mol} \%) \\
& \text { acetone, } 20{ }^{\circ} \mathrm{C}, 6 \mathrm{~h}
\end{aligned}
$$<smiles>[R]/C=C1/OC(=O)C(Br)=C1[R]</smiles>

80a : $\mathrm{R}^{1}=\mathrm{H} ; \mathrm{R}^{2}=\mathrm{Ph}$

80b : $\mathrm{R}^{1}=\mathrm{H} ; \mathrm{R}^{2}=4-\mathrm{MeC}_{6} \mathrm{H}_{4}$

80c $: \mathrm{R}^{1}=\mathrm{H} ; \mathrm{R}^{2}=n-\mathrm{Bu}$

80d : $\mathrm{R}^{1}=\mathrm{Me} ; \mathrm{R}^{2}=n-\mathrm{Bu}$

Scheme 28. Regioselective synthesis of (Z)-3-bromo-5ylidene-2 $(5 H)$-furanones 80a-d

These ethyl 2-bromo-2-en-4-ynoates were then converted into the required compounds 80a-d by saponification with $1 \mathrm{~N} \mathrm{LiOH}$, followed by acidification and lactonization of the resulting crude carboxylic acids by heating their toluene solution under argon at $110{ }^{\circ} \mathrm{C}$ for $16-24 \mathrm{~h}$ in the presence of $5 \mathrm{~mol} \%$ trans-di $(\mu-$ acetato)bis[o-(di-o-tolylphosphino)benzyl]dipalladium(II) (Herrmann's palladacycle). Compounds 80a, 80b, 80c and 80d were so obtained in 45, 36, 50 and $25 \%$ yield, respectively. Notably, compounds $\mathbf{8 0 a}-\mathbf{c}$ were obtained together with $3-6 \%$ of the corresponding 3-bromo- $2 \mathrm{H}$ pyran-2-ones 84a-c, but 80d was obtained together with a significant amount of pyranone $\mathbf{8 4 d}$, which was isolated in $45 \%$ yield. Nevertheless, when the cyclization reaction of the crude carboxylic acid derived from 83d was carried out in acetone at $20{ }^{\circ} \mathrm{C}$ for $6 \mathrm{~h}$ in the presence of $20 \mathrm{~mol} \%$ $\mathrm{AgNO}_{3}$ a mixture of $\mathbf{8 0 d}$ and $\mathbf{8 4 d}$ in ca. $79: 21$ ratio was obtained from which pure $\mathbf{8 0 d}$ was isolated in $52 \%$ yield [69]. Compound 80d was then used as direct precursor to bovolide (86), a natural compound first found in butter [73]. In fact, the reaction of $\mathbf{8 0 d}$ with 1.5 equiv of tetramethyltin (85) in NMP at $80{ }^{\circ} \mathrm{C}$ for $72 \mathrm{~h}$ in the presence of $5 \mathrm{~mol} \% \mathrm{PdCl}_{2}(\mathrm{PhCN})_{2}, 10 \mathrm{~mol} \% \mathrm{AsPh}_{3}$ and 10 mol\% CuI gave 86 in 54\% yield (Scheme 29) [69].
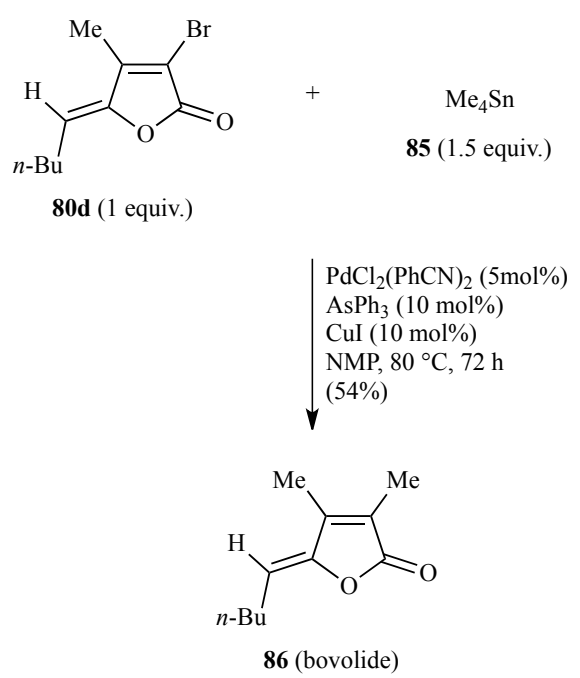

Scheme 29. Synthesis of bovolide (86)

In 2001, 4-aryl-3-bromo-2(5H)-furanones $\mathbf{3 1}$ were synthesized by our research group using a novel protocol that involved the $\mathrm{PdCl}_{2}(\mathrm{MeCN})_{2} / \mathrm{AsPh}_{3}$-catalyzed regioselective Suzuki-Miyaura reaction of 3,4-dibromo2(5H)-furanone (2) with 1.1 equiv of arylboronic acids (87) in THF at $65{ }^{\circ} \mathrm{C}$ and 3.0 equiv of $\mathrm{Ag}_{2} \mathrm{O}$ [74]. Scheme 30 depicts the synthesis of compounds 31a, 31f and $\mathbf{3 1 g}$ in $66 \%, 79 \%$ and $61 \%$ yield, respectively, according to this protocol.

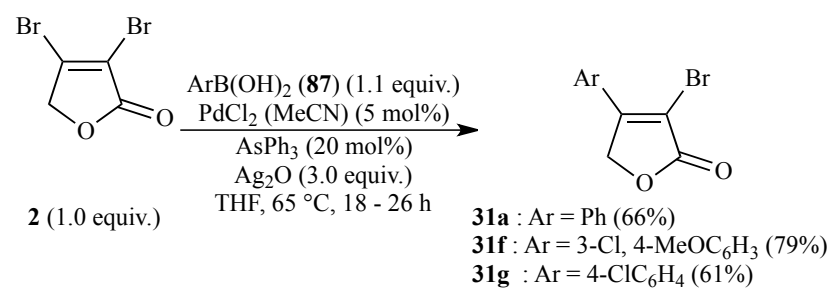

Scheme 30. Synthesis of compounds 31a, 31f and $\mathbf{3 1 g}$ via regioselective Suzuki-Miyaura reaction

On the other hand, the Stille-type reaction of 2 with 1.1 equiv of (4-methoxyphenyl)tributyltin (30a) in NMP at room temperature in the presence of a $\mathrm{Pd}_{2}(\mathrm{dba})_{3} / \mathrm{AsPh}_{3}$ catalyst system provided regioselectively 3-bromo-4-(4methoxyphenyl)-2(5H)-furanone (31c) in $68 \%$ yield (Scheme 31) [74]. 
<smiles>COc1ccc([18O]c2ccccc2)cc1</smiles><smiles>COc1ccc(C2=C(Br)C(=O)OC2)cc1</smiles>

Scheme 31. Synthesis of compounds 31c via a Stilletype coupling reaction

Compounds 31f and 31c were then used as advanced precursors to (Z)-4-aryl-5-(1-arylmethylene)-3-bromo2(5H)-furanones 89a and $\mathbf{8 9} \mathbf{b}$, respectively. In particular, 31f and 31c were treated with tert-butyldimethylsilyl trifluoromethanesulfonate (TBDMSOTf) and diisopropylethylamine yielding the corresponding silyl ethers that were not isolated, but immediately reacted with aldehydes $\mathbf{8 8 a}$ and $\mathbf{8 8 b}$, respectively. The resulting compounds were not isolated, but submitted to reaction with DBU providing compounds 89a and 89b in 95\% and 99\% yield, respectively (Scheme 32) [74].

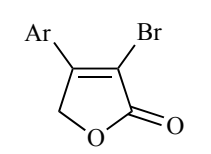

31f (1.0 equiv.) $31 \mathrm{c}$$$
\mid \begin{aligned}
& \text { 1) } \operatorname{TBDMSOTf}(1.0 \text { equiv. }) \\
& i \text { - } \mathrm{Pr}_{2} \mathrm{NEt}(3.0 \text { equiv. }) \\
& \mathrm{CH}_{2} \mathrm{Cl}_{2}, 20^{\circ} \mathrm{C}, 2 \mathrm{~h} \\
& \text { 2) } \mathrm{DBU}(2.0 \text { equiv. }) \\
& 20^{\circ} \mathrm{C}, 4 \mathrm{~h}
\end{aligned}
$$<smiles>[X]c1cc(/C=C2\OC(=O)C(Br)=C2[Al])cc([X])c1OC</smiles>

89

\begin{tabular}{cccc}
\hline 89 & $\mathrm{Ar}$ & $\mathrm{Z}$ & Yield\% \\
\hline 89a & $3-\mathrm{Cl}, 4-\mathrm{MeOC}_{6} \mathrm{H}_{3}$ & $\mathrm{Cl}$ & 95 \\
$\mathbf{8 9 b}$ & $4-\mathrm{MeOC}_{6} \mathrm{H}_{4}$ & $\mathrm{H}$ & 99 \\
\hline
\end{tabular}

Scheme 32. Stereoselective synthesis of (Z)-4-aryl-5-(1arylmethylene)-3-bromo-2(5H)-furanones 89a and $\mathbf{8 9 b}$

In 2012, our protocol [74] was employed by Barbosa, Forlani and coworkers to prepare (Z)-4-aryl-5-(1arylmethylene)-3-bromo-2(5H)-furanones 90a-k (Figure 8) in modest to satisfactory yields starting from 3,4dibromo-2(5H)-furanone (2) [75]. Notably, all compounds 90, except $90 \mathbf{j}$, appeared capable to interfere with the photosynthetic electron transport chain in the chloroplasts. The $\mathrm{IC}_{50}$ values of the most active compounds, $90 \mathrm{~b}$ and 90c, were only 1 order of magnitude higher than those of commercial herbicides sharing the same mode of action [75].<smiles>[R]c1cc(/C=C2\OC(=O)C(Br)=C2[Al])cc([R])c1[R]</smiles>

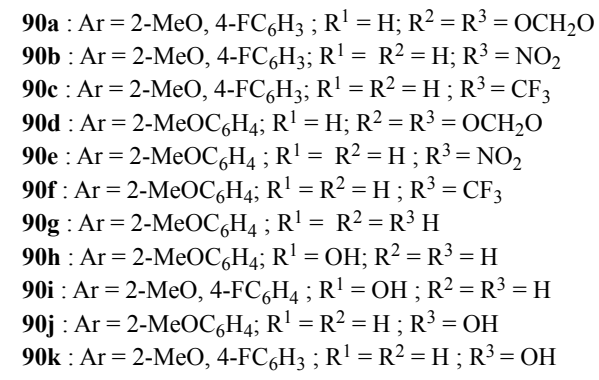

Figure 8. Structures of compounds $90 \mathbf{a}-\mathbf{k}$

In 2015, the same research group synthesized stereoisomerically pure compounds $(Z)-91 \mathbf{a}$ and $(Z)-91 \mathbf{c}-\mathbf{j}$ and $(E)(Z)-91 b$ (Figure 9$)$ by the same procedure used in 2012 to prepare $\mathbf{9 0 a}-\mathbf{k}$ [75]. 
<smiles>[R]c1ccc(/C=C2\OC(=O)C(Br)=C2[Tl])c([R])c1[R]</smiles>

(Z)-91a : $\mathrm{Ar}=2-\mathrm{MeO}, 5-\mathrm{ClC}_{6} \mathrm{H}_{3} ; \mathrm{R}^{1}=\mathrm{R}^{2}=\mathrm{H} ; \mathrm{R}^{3}=\mathrm{F}$ (E)/(Z)-91b : $\mathrm{Ar}=2-\mathrm{MeO}, 5-\mathrm{ClC}_{6} \mathrm{H}_{3} ; \mathrm{R}^{1}=\mathrm{R}^{2}=\mathrm{H} ; \mathrm{R}^{3}=\mathrm{NO}_{2}$ (Z)-91c : $\mathrm{Ar}=2-\mathrm{MeO}, 5-\mathrm{ClC}_{6} \mathrm{H}_{3} ; \mathrm{R}^{1}=\mathrm{R}^{2}=\mathrm{H} ; \mathrm{R}^{3}=\mathrm{CF}_{3}$ (Z)-91d : $\mathrm{Ar}=2-\mathrm{MeO}, 5-\mathrm{ClC}_{6} \mathrm{H}_{3} ; \mathrm{R}^{1}=\mathrm{R}^{3}=; \mathrm{R}^{2}=\mathrm{NO}_{2}$ (Z)-91e : $\mathrm{Ar}=2-\mathrm{MeO}, 5-\mathrm{BrC}_{6} \mathrm{H}_{3} ; \mathrm{R}^{1}=\mathrm{R}^{2}=\mathrm{H} ; \mathrm{R}^{3}=\mathrm{CF}_{3}$ (Z)-91f: $\mathrm{Ar}=2-\mathrm{MeO}, 5-\mathrm{BrC}_{6} \mathrm{H}_{3} ; \mathrm{R}^{1}=\mathrm{Br} ; \mathrm{R}^{2}=\mathrm{R}^{3}=\mathrm{H}$ (Z)-91g: $\mathrm{Ar}=2-\mathrm{MeO}, \mathrm{BrC}_{6} \mathrm{H}_{3} ; \mathrm{R}^{1}=\mathrm{R}^{2}=; \mathrm{R}^{3}=\mathrm{F}$ (Z)-91h : $\mathrm{Ar}=2 \_\mathrm{MeO}, 5-\mathrm{BrC}_{6} \mathrm{H}_{3} ; \mathrm{R}^{1}=\mathrm{Cl} ; \mathrm{R}^{2}=\mathrm{R}^{3}=\mathrm{H}$ (Z)-91i : $\mathrm{Ar}=2-\mathrm{MeO}, 5-\mathrm{BrC}_{6} \mathrm{H}_{3} ; \mathrm{R}^{1}=\mathrm{R}^{3}=\mathrm{H} ; \mathrm{R}^{2}=\mathrm{OMe}$ (Z)-91j: $\mathrm{Ar}=2-\mathrm{MeO}, 5-\mathrm{BrC}_{6} \mathrm{H}_{3} ; \mathrm{R}^{1}=\mathrm{R}^{3}=\mathrm{H} ; \mathrm{R}^{2}=\mathrm{F}$

Figure 9. Structures of compounds $(Z)-91 \mathbf{a},(Z)-91 \mathbf{c}-\mathbf{j}$, and $(E)(\mathrm{Z})-\mathbf{9 1 b}$

All these substances were then evaluated for their abilities of interfering with the light-driven reduction of ferricyanide by isolated spinach chloroplasts and it was found that at $10 \mu \mathrm{M}$ compound $(E)(\mathrm{Z})-91 \mathrm{~b}$ showed the highest effectiveness and that compounds $(Z)-91 \mathrm{c},(Z)-91 \mathrm{e}$ and (Z)-91g were very active [75].

In the same year, Barbosa and coworkers also investigated the photosynthetic inhibitory activity of rubrolide analogues different from compounds $91 \mathbf{a}-\mathbf{j}$ and discovered that (Z)-4-aryl-5-(arylmethylene)-3-bromo$2(5 H)$-furanones $91 \mathbf{k}-\mathbf{s}$ (Figure 10) were capable of inhibiting the basal, uncoupled and phosphorylating electron transfer [76]. Thus, these compounds acted as inhibitors of the Hill reaction, i.e. the light-driven transfer of electrons by chloroplasts in photosynthesis that results in the cleavage of water molecules and liberation of dioxygen [77].<smiles>[R]c1ccc(/C=C2\OC(=O)C(Br)=C2[Tl])c([R])c1[R]</smiles>

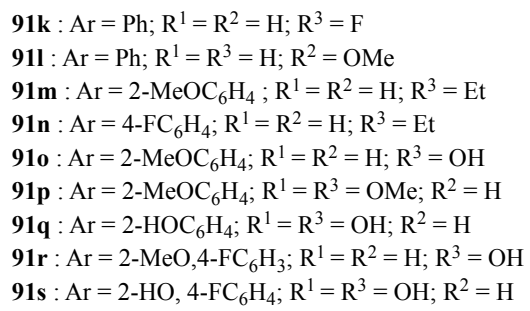

Figure 10. Structures of compounds $91 \mathrm{k}-\mathrm{s}$
In 2013, Ngi, Thibonnet and coworkers developed a new route to (Z)-5-[1-(aryl)methylene]-3-bromo-4isopropyl-2(5H)-furanones $\mathbf{9 5}$ in which 4-methyl-2pentynoic acid (92) was the starting material (Scheme 33) and used these compounds as precursors to nostoclide analogues [78].

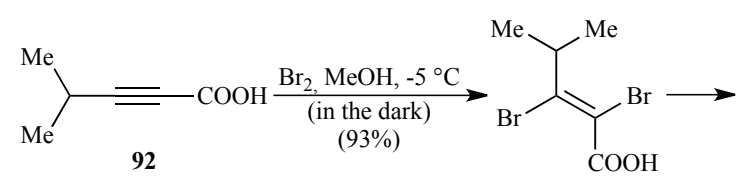

93

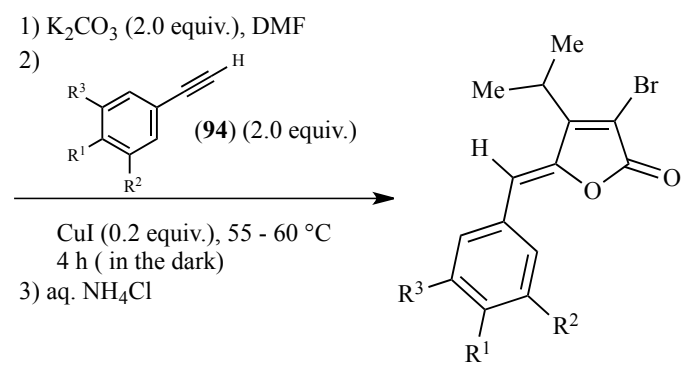

95

\begin{tabular}{ccccc}
\hline $\mathbf{9 5}$ & $\mathrm{R}^{1}$ & $\mathrm{R}^{2}$ & $\mathrm{R}^{3}$ & Yield\% \\
\hline $\mathbf{9 5 a}$ & $\mathrm{H}$ & $\mathrm{H}$ & $\mathrm{H}$ & 65 \\
$\mathbf{9 5 b}$ & $\mathrm{OH}$ & $\mathrm{H}$ & $\mathrm{H}$ & 38 \\
$\mathbf{9 5 c}$ & $\mathrm{OH}$ & $\mathrm{Cl}$ & $\mathrm{Cl}$ & 25 \\
$\mathbf{9 5 d}$ & $\mathrm{OH}$ & $\mathrm{H}$ & $\mathrm{Cl}$ & 28 \\
$\mathbf{9 5 e}$ & $\mathrm{OMe}$ & $\mathrm{H}$ & $\mathrm{Cl}$ & 65 \\
$\mathbf{9 5 f}$ & $\mathrm{OMe}$ & $\mathrm{Cl}$ & $\mathrm{Cl}$ & 68 \\
\hline
\end{tabular}

Scheme 33. Stereoselective synthesis of (Z)-5-[1(aryl)methylene]-3-bromo-4-isopropyl-2(5H)-furanones 95a-f

Specifically, addition of bromine to 92 using a previously reported protocol [79] led to compound $\mathbf{9 3}$ in $93 \%$ yield. A mixture of $\mathbf{9 3}$ and 2.0 equiv of $\mathrm{K}_{2} \mathrm{CO}_{3}$ in DMF was then stirred in the dark for $15 \mathrm{~min}$ and subsequently reacted with 2.0 equiv of arylacetylenes 94 and 0.2 equiv of $\mathrm{CuI}$ at $55-60{ }^{\circ} \mathrm{C}$ for $4 \mathrm{~h}$ under stirring. Hydrolysis of the resulting mixtures with an aqueous $\mathrm{NH}_{4} \mathrm{Cl}$ solution provided stereoselectively compounds 95a-f in yields ranging from 25 to $68 \%$ [78]. Attempts were also made to convert compounds $95 \mathrm{f}$ and $95 \mathrm{e}$ into the corresponding $O$-demethylated derivatives $95 \mathbf{c}$ and 95d, respectively, but the efforts to carry out the demethylation reaction with $\mathrm{BBr}_{3}$ or $\mathrm{HBr}$ in acetic acid were unsuccessful [78].

In 2015, Barbosa and coworkers synthesized (Z)-5-[1(aryl)methylene]-3-bromo-4-phenyl-2( $5 H)$-furanones $\mathbf{9 7 a}$ and $97 \mathbf{b}$ in $44 \%$ and $70 \%$ yield, respectively, via aldol 
condensation of 3-bromo-4-phenyl-2(5H)-furanone (31a) with the required aryl aldehydes 96 (Scheme 34) [80].

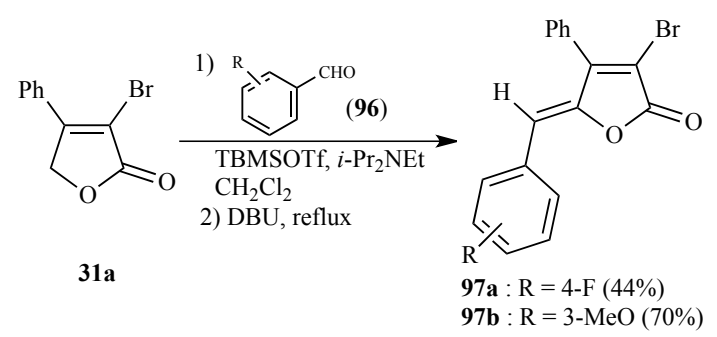

Scheme 34. Stereoselective synthesis of (Z)-5-[1(aryl)methylene]-3-bromo-4-phenyl-2(5H)-furanones $\quad \mathbf{9 7 a}$ and 97b

Compounds 97a and 97b, which similarly to compounds 91 are analogues of rubrolides, a class of natural 2(5H)-furanones from marine invertebrates [81], were then assayed for their effect on non-cyclic electron transport from water to methylviologen under basal phosphorylation and uncoupled conditions and it was found that 97a bearing a fluorine atom in the benzylidene group showed markedly higher activity than $97 \mathbf{b}$ [80].

Still in 2015, Médebielle and coworkers carried out the synthesis of (Z)-4-alkoxy-5-[1(aryl)methylene]-3-bromo2(5H)-furanones $\mathbf{1 0 2} \mathbf{a}-\mathbf{g}$ starting from 4-alkoxy-2 $(5 H)$ furanones 98 through the multistep route outlined in Scheme 35 [82]. The reaction of compounds 98 with $n$ BuLi and aldehydes 99 in THF yielded aldol adducts 100 which were directly converted to 4-alkoxy-5-[1(aryl)methylene]-2(5H)-furanones 101a-g via a twostep/one-pot sequence involving an esterification reaction with trifluoroacetic anhydride and a DBU-mediated elimination reaction. Compounds 101a and 101c-g were obtained as stereoisomerically pure $Z$-configured stereoisomers, but 101b was obtained as a $96: 4$ mixture of $Z$ and $E$ stereoisomers, respectively. A bromine atom was then introduced on the C-3 position of compounds 101 by treatment with 1.2-1.5 equiv of bromine in the presence of pyridine. Purification of the resulting reaction mixtures by silica gel chromatography allowed to obtain stereoisomerically pure compounds $(Z)-\mathbf{1 0 2} \mathbf{a}-\mathbf{g}$ in yields ranging from 60 to $91 \%$ (Scheme 35) [82].

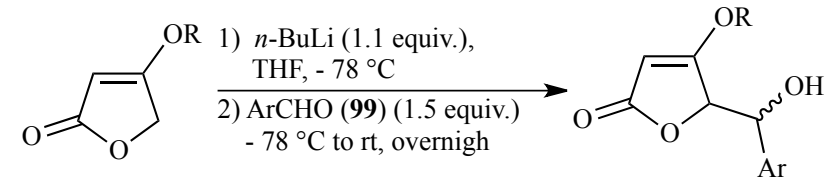

$98\left(\mathrm{R}^{1}=\mathrm{Me}, \mathrm{Bn}\right)$

100

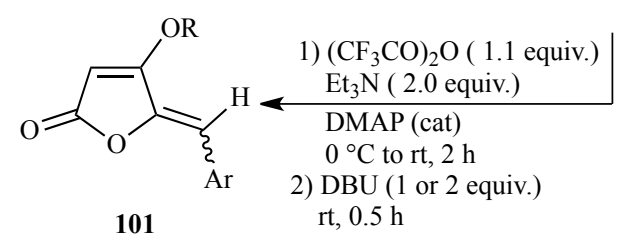

1) $\mathrm{Br}_{2}$ (1.2 - 1.5 equiv.) pyridine (1.2 - 2.0 equiv.) $\mathrm{CH}_{2} \mathrm{Cl}_{2}, 20$ min to $2 \mathrm{~h}$ 2) silicagel chromatography<smiles>[Y8]/C=C1/OC(=O)C(Br)=C1O[R]</smiles>

102

\begin{tabular}{ccccc}
\hline 101 & $\mathrm{R}$ & $\mathrm{Ar}$ & $Z / E$ & Yield\% \\
\hline 101a & $\mathrm{Me}$ & $\mathrm{Ph}$ & $100: 0$ & 39 \\
101b & $\mathrm{Me}$ & $3,4-\mathrm{F}_{2} \mathrm{C}_{6} \mathrm{H}_{3}$ & $96: 4$ & 32 \\
$\mathbf{1 0 1 c}$ & $\mathrm{Me}$ & $4-\mathrm{CF}_{3} \mathrm{C}_{6} \mathrm{H}_{4}$ & $100: 0$ & 43 \\
101d & $\mathrm{Me}$ & $3,4-(\mathrm{MeO})_{2} \mathrm{C}_{6} \mathrm{H}_{3}$ & $100: 0$ & 39 \\
101e & $\mathrm{Bn}$ & $\mathrm{Ph}_{2}$ & $100: 0$ & 47 \\
101f & $\mathrm{Bn}$ & $4-\mathrm{CF}_{3} \mathrm{C}_{6} \mathrm{H}_{4}$ & $100: 0$ & 57 \\
101g & $\mathrm{Bn}$ & $3,4-(\mathrm{MeO})_{2} \mathrm{C}_{6} \mathrm{H}_{3}$ & $100: 0$ & 18 \\
\hline
\end{tabular}

\begin{tabular}{ccccc}
\hline $\mathbf{1 0 2}$ & equiv. of $\mathrm{Br}_{2}$ & $\mathrm{R}$ & $\mathrm{Ar}$ & Yield\% \\
\hline $\mathbf{1 0 2 a}$ & 1.5 & $\mathrm{Me}$ & $\mathrm{Ph}$ & 91 \\
$\mathbf{1 0 2 b}$ & 1.5 & $\mathrm{Me}$ & $3,4-\mathrm{F}_{2} \mathrm{C}_{6} \mathrm{H}_{3}$ & 81 \\
$\mathbf{1 0 2 c}$ & 1.2 & $\mathrm{Me}$ & $4-\mathrm{CF}_{3} \mathrm{C}_{6} \mathrm{H}_{4}$ & 62 \\
$\mathbf{1 0 2 d}$ & 1.5 & $\mathrm{Me}$ & $3,4-(\mathrm{MeO})_{2} \mathrm{C}_{6} \mathrm{H}_{3}$ & 60 \\
$\mathbf{1 0 2 e}$ & 1.5 & $\mathrm{Bn}$ & $\mathrm{Ph}$ & 79 \\
$\mathbf{1 0 2 f}$ & 1.5 & $\mathrm{Bn}$ & $4-\mathrm{CF}_{3} \mathrm{C}_{6} \mathrm{H}_{4}$ & 65 \\
$\mathbf{1 0 2 g}$ & 1.2 & $\mathrm{Bn}$ & $3,4-(\mathrm{MeO})_{2} \mathrm{C}_{6} \mathrm{H}_{3}$ & 64 \\
\hline
\end{tabular}

Scheme 35. Synthesis of compounds 101a-g and 102a-g

\subsection{SYNTHESIS AND BIOACTIVITY OF 4-BROMO- 2(5H)-FURANONE DERIVATIVES}

In 1953, Schenk synthesized 4-bromo-5-methoxy$2(5 H)$-furanone $(\mathbf{1 0 4})$ in $85 \%$ yield by bromination of 5 methoxy-2(5H)-furanone $(\mathbf{1 0 3})$ in benzene at $0{ }^{\circ} \mathrm{C}$ (Scheme 36) [83].

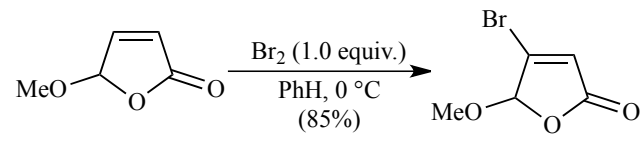

103 
Scheme 36. Synthesis of 4-bromo-5-methoxy-2(5H)furanone (104)

In 1996, Martin and coworkers converted compound 104 into 4-bromo-5-phenylthio-2 $(5 H)$-furanone (106) by treatment with a large molar excess of thiophenol (105) in $\mathrm{CH}_{2} \mathrm{Cl}_{2}$ under reflux in the presence of 2.0 equiv of $\mathrm{BF}_{3} \cdot \mathrm{Et}_{2} \mathrm{O}$ (Scheme 37) [84].

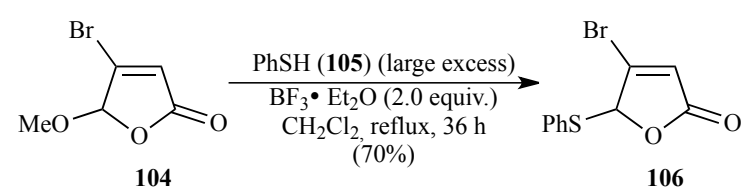

Scheme 37. Synthesis of 4-bromo-5-phenylthio-2 $(5 H)$ furanone (106)

In 1963, Mabry reported that 4-bromo-2(5H)-furanone (108) could be obtained in a very low yield (ca. 3\%) by the reaction of 2-furoic acid (107) with 2.1 equiv of bromine in water at $28-30{ }^{\circ} \mathrm{C}$ for $60 \mathrm{~min}$ (Scheme 38) [85].

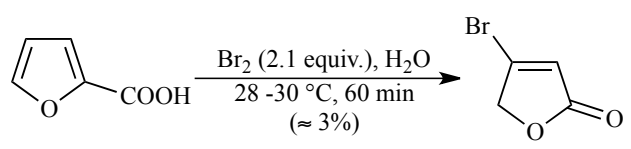

107

108

Scheme 38. Synthesis of 4-bromo-2(5H)-furanone (108) from 2-furoic acid (107)

Nevertheless, in 1991, compound $\mathbf{1 0 8}$ was prepared by Jas in $86 \%$ yield on a $30 \mathrm{~g}$ scale by treatment of $\beta$-tetronic acid (2,4-(3H,5H-furandione) (109) with a Vilsmeier reagent prepared from oxalyl bromide (110) and DMF (Scheme 39) [86].

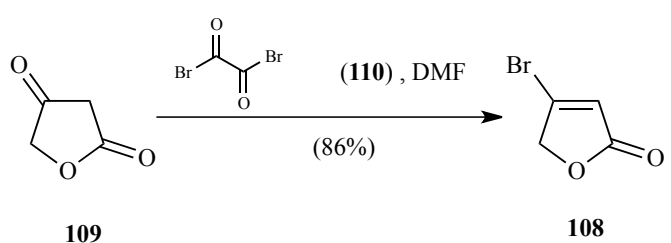

Scheme 39 Synthesis of 4-bromo-2(5H)-furanone (108) from $\beta$-tetronic acid (109)

One year earlier, 4-bromo-3-methyl-2(5H)-furanone (112) had been synthesized by Svendson and Sydnes in $67 \%$ yield by treatment of 2,2-dibromo-1methylcyclopropanecarboxylic acid (111) with 1.55 equiv of $\mathrm{CF}_{3} \mathrm{COOAg}$ in 2,2,2-trifluoroethanol (TFE) under reflux for $19 \mathrm{~h}$ and chromatographic purification of the resulting crude reaction product (Scheme 40) [87].

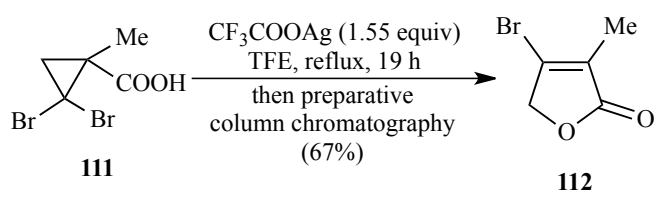

Scheme 40. Synthesis of 4-bromo-3-methyl-2(5H)furanone (112)

Again in 1990 Font, Gracia, and de March described an elegant method that allowed them to prepare 4-bromo2(5H)-furanones 114a and 114b, 4-bromo-5-methylene2(5H)-furanone (117a) and 4-bromo-5-isopropylidene$2(5 H)$-furanone $(\mathbf{1 1 7 b})$ in satisfactory yields starting from methyl 4-alkyl-2,3-butadienoates 113a and 113b, respectively (Scheme 41) [88].
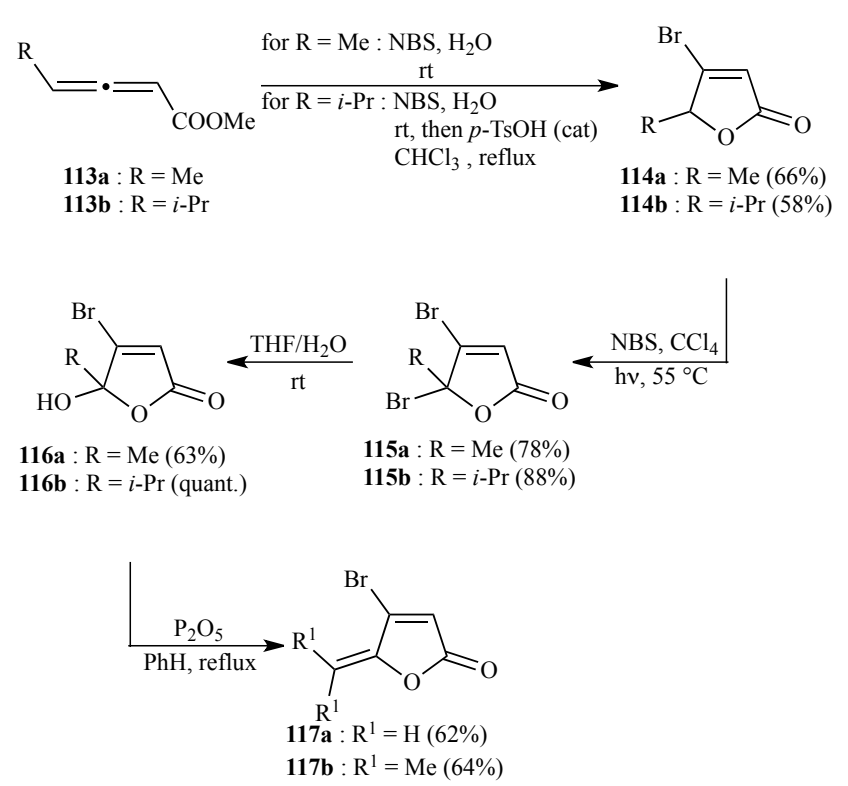

Scheme 41. Synthesis of 4-bromo-2(5H)-furanones 114a,b and 4-bromo-5-ylidene-2(5H)-furanones 117a,b

In particular, the reaction of 113a with NBS in water at room temperature gave 114a in $66 \%$ yield. On the other hand, 114b was obtained in 58\% yield by treatment of 113b with NBS in water at room temperature and heating at reflux of a $\mathrm{CHCl}_{3}$ solution of the resulting product in the presence of a catalytic amount of $p-\mathrm{TsOH}$. Allylic bromination of 114a with NBS under irradiation with an incandescent lamp afforded 4,5-dibromo-2 $(5 H)$-furanone 115a in 78\% yield, which was converted to 4-bromo-5hydroxy-5-methyl-2(5H)-furanone (116a) in 63\% yield by treatment with a mixture of THF and water. Finally, dehydration of $116 \mathbf{a}$ with $\mathrm{P}_{2} \mathrm{O}_{5}$ in benzene under reflux gave $117 \mathrm{a}$ in $62 \%$ yield. The same reaction sequence was then used to prepare $117 \mathbf{b}$ from $114 b$. In fact, allylic bromination of $\mathbf{1 1 4 b}$ gave $\mathbf{1 1 5 b}$ in $88 \%$ yield. Hydrolysis of this compound provided $\mathbf{1 1 6 b}$ in quantitative yield, 
which was dehydrated with $\mathrm{P}_{2} \mathrm{O}_{5}$ in refluxing benzene giving rise to $119 \mathrm{~b}$ in $64 \%$ yield [88].

In 1998, Sydnes and coworkers reinvestigated the solvolysis of 2,2-dibromo-1-methylcyclopropane carboxylic acid (118a) in TFE in the presence of $\mathrm{CF}_{3} \mathrm{COOAg}$ and found that the reaction in TFE under reflux for $24 \mathrm{~h}$ in the presence of 1.16 equiv of $\mathrm{CF}_{3} \mathrm{COOAg}$ gave 4-bromo-3-methyl-2(5H)-furanone (112) in 93\% yield (Scheme 42) [89]. The same reaction conditions were then used to prepare 4-bromo-3,5-dimethyl-2 $(5 H)$-furanone (119) in 54\% yield from trans-2,2-dibromo-1,3dimethylcyclopropanecarboxylic acid (118b) (Scheme 42) [89].
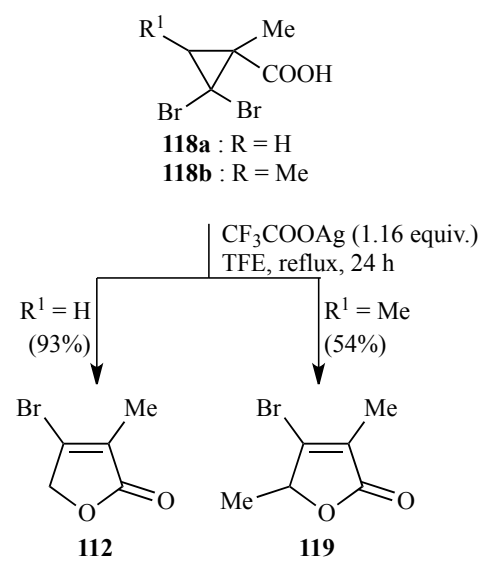

Scheme 42. Synthesis of 4-bromo-2(5H)-furanones 112 and 119

It deserves also to be mentioned that, in the late 1990s and early 2000s, a significant contribution to the development of efficient and selective methods for the synthesis of variously substituted 4-bromo-2(5H)furanones was given by the research group of Ma. In 1999, this group reported that 5-alkyl-4-bromo-2 $(5 H)$-furanones 114c and 114d could be synthesized in high yields by the reaction of allenecarboxylic acids $120 a$ and $\mathbf{1 2 0 b}$, respectively, with 2.0 equiv of $\mathrm{NBS}$ and 1.0 equiv of $\mathrm{K}_{2} \mathrm{CO}_{3}$ in water at $25^{\circ} \mathrm{C}$ (Scheme 43$)[90,91]$.

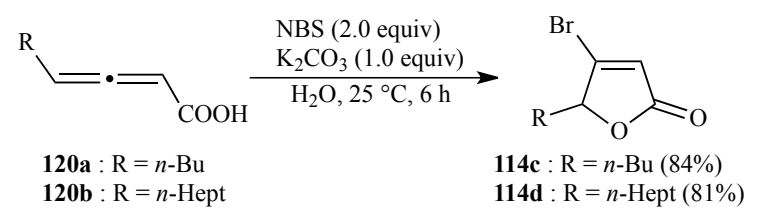

Scheme 43. Synthesis of 5-alkyl-4-bromo-2(5H)furanones $114 \mathrm{c}$ and $\mathbf{1 1 4 d}$ fromn allenecarboxylic acids $120 \mathrm{a}$ and $120 \mathrm{~b}$, respectively

In the same year, $\mathrm{Ma}$ and $\mathrm{Wu}$ reported that 4-bromo$2(5 H)$-furanones $122 \mathbf{a}-\mathbf{f}$ could be obtained in high to excellent yields by treatment of 2,3-allenoic acids 121a-f with 4.0 equiv of $\mathrm{CuBr}_{2}$ in a $2: 1$ mixture of acetone and water at $65-70{ }^{\circ} \mathrm{C}$ for $2 \mathrm{~h}$ (Scheme 44) [92].

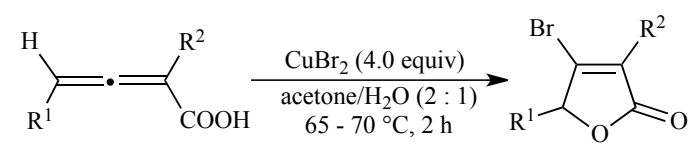

121

122

\begin{tabular}{cccc}
\hline 122 & $\mathrm{R}^{1}$ & $\mathrm{R}^{2}$ & Yield\% \\
\hline 122a & $\mathrm{Ph}$ & $\mathrm{Me}$ & 96 \\
122b & $n$-Hept & $\mathrm{H}$ & 85 \\
122c & $c-\mathrm{C}_{6} \mathrm{H}_{11}$ & $\mathrm{H}$ & 94 \\
122d & $\mathrm{Ph}$ & $n$ - $\mathrm{Pr}$ & 99 \\
122e & 1 -naphthyl & $\mathrm{Me}$ & 89 \\
122f & 1-naphthyl & $n$ - $\mathrm{Pr}$ & 98 \\
\hline
\end{tabular}

Scheme 44. Synthesis of 4-bromo-2(5H)-furanones 122a-f from 2,3-allenoic acids $121 \mathbf{a}-\mathbf{f}$

In 2001, Ma and Shi improved their protocol for the bromolactonization reaction of 2,3-allenoic acids with NBS and found that the reaction of carboxylic acids $123 \mathbf{a}-\mathbf{f}$ with 1.1 equiv of $\mathrm{NBS}$ and 0.5 equiv of $\mathrm{K}_{2} \mathrm{CO}_{3}$ in water at room temperature produced 4-bromo-2(5H)-furanones 124a-f in yields ranging from 81 to $99 \%$ (Scheme 45) [93].

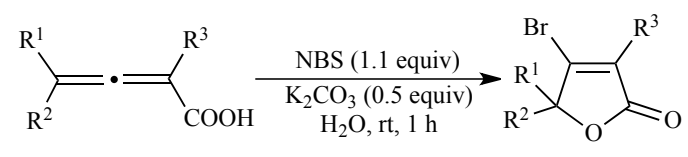

123

124

\begin{tabular}{ccccc}
\hline $\mathbf{1 2 4}$ & $\mathrm{R}^{1}$ & $\mathrm{R}^{2}$ & $\mathrm{R}^{3}$ & Yield\% \\
\hline 124a & $n$-Bu & $\mathrm{H}$ & $\mathrm{H}$ & 84 \\
$\mathbf{1 2 4 b}$ & $n$-Hept & $\mathrm{H}$ & $\mathrm{H}$ & 81 \\
$\mathbf{1 2 4 c}$ & $\mathrm{Ph}$ & $\mathrm{H}$ & $\mathrm{Me}$ & 94 \\
$\mathbf{1 2 4 d}$ & $\mathrm{Ph}$ & $\mathrm{H}$ & $n-\mathrm{Pr}$ & 99 \\
$\mathbf{1 2 4 e}$ & $1-n a p h t h y l$ & $\mathrm{H}$ & $\mathrm{Me}$ & 98 \\
$\mathbf{1 2 4 f}$ & $\mathrm{Ph}$ & $\mathrm{Me}$ & $\mathrm{H}$ & 99 \\
\hline
\end{tabular}

Scheme 45. Synthesis of 4-bromo-2(5H)-furanones $\mathbf{1 2 4} \mathbf{a}-\mathbf{f}$ by bromolactonization of 2,3-allenoic acids $\mathbf{1 2 3} \mathbf{a}-\mathbf{f}$ with $\mathrm{NBS} / \mathrm{K}_{2} \mathrm{CO}_{3}$ in water

Again in 2001, Ma and Wu demonstrated that ethyl 2,3allenoates $\mathbf{1 2 5}$, which were the precursors to compounds 123, could be directly used as substrates of bromolactonization reactions with $\mathrm{CuBr}_{2}$ [94]. In particular, it was found that compounds $\mathbf{1 2 5}$ with different substitution patterns were able to react with 4.0 equiv of $\mathrm{CuBr}_{2}$ in a $3: 2$ mixture of $\mathrm{EtOH}$ and water at $80-85^{\circ} \mathrm{C}$ for $12 \mathrm{~h}$ to give 4-bromo-2(5H)-furanones $\mathbf{1 2 4}$ in yields ranging from 40 to $97 \%$. As shown in Scheme 46, this protocol was used for the synthesis of compounds $124 \mathbf{g}-\mathbf{q}$ [94]. 


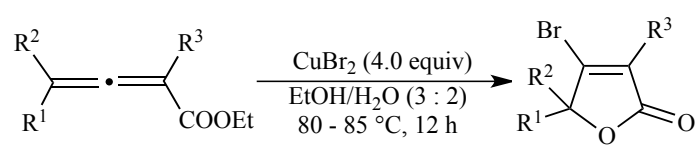

125

124

\begin{tabular}{ccccc}
\hline $\mathbf{1 2 4}$ & $\mathrm{R}^{1}$ & $\mathrm{R}^{2}$ & $\mathrm{R}^{3}$ & Yield\% \\
\hline $\mathbf{1 2 4 g}$ & $n$-Hex & $\mathrm{H}$ & $n$-Pr & 95 \\
$\mathbf{1 2 4 h}$ & $n$-Hex & $\mathrm{H}$ & $\mathrm{Bn}$ & 97 \\
$\mathbf{1 2 4} \mathbf{i}$ & $i$-Pr & $\mathrm{H}$ & $\mathrm{Bn}$ & 78 \\
$\mathbf{1 2 4 j}$ & $i$-Pr & $\mathrm{H}$ & $n$-Pr & 68 \\
$\mathbf{1 2 4 k}$ & $i$-Pr & $\mathrm{H}$ & $\mathrm{Me}$ & 86 \\
$\mathbf{1 2 4 l}$ & $\mathrm{Me}$ & $\mathrm{H}$ & $\mathrm{Me}$ & 72 \\
$\mathbf{1 2 4 m}$ & $\mathrm{Me}$ & $\mathrm{H}$ & $n$-Pr & 84 \\
$\mathbf{1 2 4 n}$ & $\mathrm{Me}$ & $\mathrm{Me}$ & $\mathrm{Me}$ & 68 \\
$\mathbf{1 2 4 0}$ & $\mathrm{Me}$ & $\mathrm{Me}$ & $n$-Pr & 66 \\
$\mathbf{1 2 4 p}$ & $n-\mathrm{Pr}$ & $\mathrm{H}$ & allyl & 54 \\
$\mathbf{1 2 4 q}$ & $\mathrm{Ph}$ & $\mathrm{H}$ & $\mathrm{Me}$ & 40 \\
\hline
\end{tabular}

Scheme 46. Bromolactonization of ethyl 2,3-allenoates 125 with $\mathrm{CuBr}_{2}$

Finally, in 2004, Ma and coworkers synthesized 3-alkyl-5aryl-4-bromo-5-hydroxy-2 $(5 H)$-furanones $\mathbf{1 2 8 a}-\mathbf{d}$ via sequential $\mathrm{CuBr}_{2}$-mediated bromolactonizationhydroxylation of 4-aryl-2,3-allenoic acids 126a-d (Scheme 47) [95].

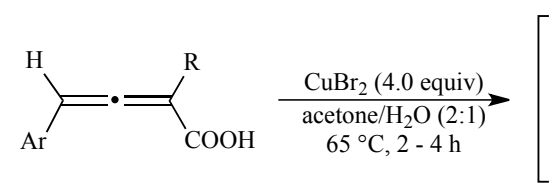

126<smiles>[R]C1=C(Br)C(Br)OC1=O</smiles>

127

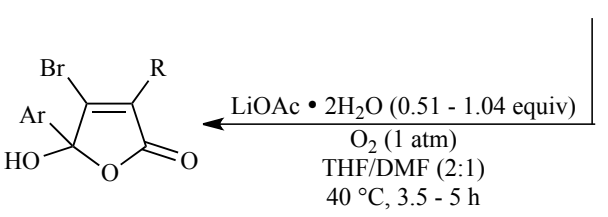

128

\begin{tabular}{ccccc}
\hline 128 & $\mathrm{Ar}$ & $\mathrm{R}$ & equiv of $\mathrm{LiOAc} \bullet \mathrm{H}_{2} \mathrm{O}$ & $\mathrm{Yield} \%$ \\
\hline 128a & $\mathrm{Ph}$ & $\mathrm{Me}$ & 1.04 & 54 \\
128b & $\mathrm{Ph}$ & $n-\mathrm{Pr}$ & 0.51 & 50 \\
128c & $\mathrm{Ph}$ & $\mathrm{Bn}$ & 1.00 & 49 \\
128d & 1-naphthyl & $n-\mathrm{Pr}$ & 1.02 & 77 \\
\hline
\end{tabular}

Scheme 47. Synthesis of 3-alkyl-5-aryl-4-bromo-5hydroxy-2 $(5 H)$-furanones 128a-d

Specifically, the crude 4-bromo-2(5H)-furanones (127), which were obtained by $\mathrm{CuBr}_{2}$-mediated bromolactonization of compounds 126a-d with 4.0 equiv of $\mathrm{CuBr}_{2}$ in a mixture of acetone and water at $65{ }^{\circ} \mathrm{C}$, were hydroxylated with dioxygen $(1 \mathrm{~atm})$ in the presence of 0.5 1.0 equiv of LiOAc. $2 \mathrm{H}_{2} \mathrm{O}$ in a mixture of THF and DMF at
$40{ }^{\circ} \mathrm{C}$ leading to compounds $\mathbf{1 2 8 a}-\mathbf{d}$ in yields ranging from 49 to $77 \%$ [95].

Previously, Lattermann and coworkers had briefly described a synthesis of 4-bromo-5-hydroxy-2 $(5 H)$ furanone (130) from furfural (8) without reporting the experimental conditions and yields of the employed reactions [96]. These authors found that furfural (8) was converted to 5 -methoxy-2(5H)-furanone (10) by treatment with singlet oxygen using methylene blue as sensitizer in methanol (Scheme 48). Addition of bromine to a $\mathrm{CHCl}_{3}$ solution of $\mathbf{1 0}$ in the presence of a catalytic amount of $\mathrm{PBr}_{3}$, followed by distillation under vacuum of the resulting compound with elimination of $\mathrm{HBr}$ gas gave crystalline 4-bromo-5-methoxy-2(5H)-furanone (129). Finally, treatment of this compound with $1 \%$ sulfuric acid in dioxane under reflux produced compound $\mathbf{1 3 0}$ in a good yield (Scheme 48) [96].

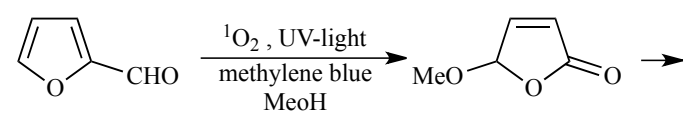

8

10

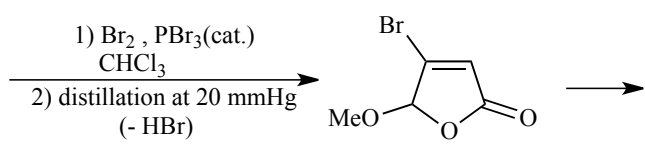

129

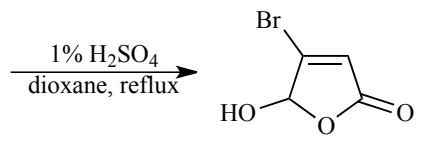

130

Scheme 48. Synthesis of 4-bromo-5-hydroxy-2(5H)furanone (130) from furfural (8)

In the past years, studies have also been conducted on the synthesis of naturally-occurring 4-bromo-5-hydroxy-3(1-hydroxybutyl)-5-methyl-2(5H)-furanone (131), a metabolite called bromobeckerelide (Figure 11) that was isolated from the marine red alga Beckerella subcostatum [95] and was found to exhibit remarkable activity against Bacillus subtilis. In fact, $0.5 \mathrm{mg}$ of $\mathbf{1 3 1}$ caused $10 \mathrm{~mm}$ diameter of inhibitory zone (in the paper disk method) [97].<smiles>[Y6]C1(O)OC(=O)C(C(O)CCC)=C1Br</smiles>

131 (bromo beckerelide)

Figure 11. Structure of bromobeckerelide (131) 
In 1989, Jefford and coworkers accomplished the first total synthesis of 131 in five steps using 5-methylfurfural (132) as the starting material (Scheme 49) [98]. In this synthesis, for which the various steps were also briefly described by Jefford in 1993 [99], bromination of 132 under $\mathrm{AlCl}_{3}$ catalysis gave 4-bromo-5-methylfurfural (133) in 80\% yield.
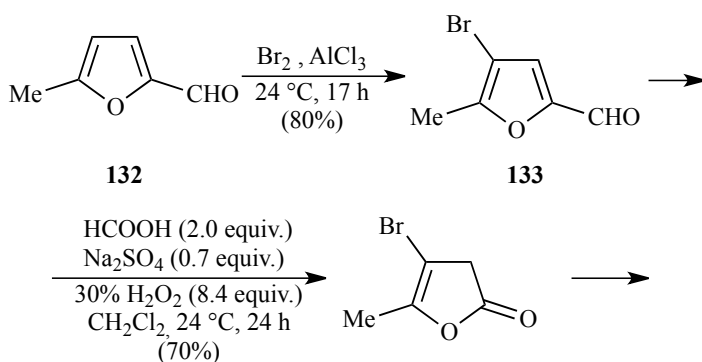

134
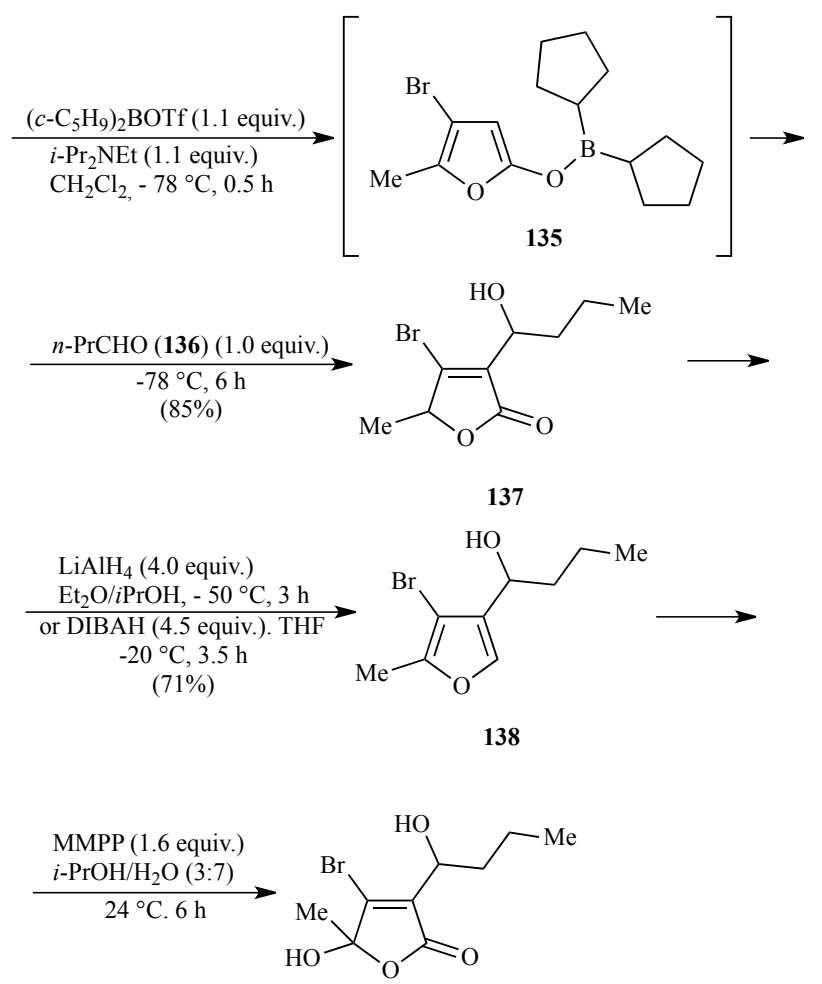

131

Scheme 49. Total synthesis of bromobeckerelide (131) starting from 5-methylfurfural (132)

Bayer-Villiger oxidation of 133 gave lactone 134, which was converted to a boron furanolate (135). The reaction of this crude compound with butanal (136) at $-78{ }^{\circ} \mathrm{C}$ generated 4-bromo-3-(1-hydroxybutyl)-5-methyl-2(5H)furanone (137) in $85 \%$ yield. Reduction of 137 with $\mathrm{LiAlH}_{4}$ in a mixture of $\mathrm{Et}_{2} \mathrm{O}$ and $i-\mathrm{PrOH}$ at $-50{ }^{\circ} \mathrm{C}$ or with DIBAH in THF at $-20{ }^{\circ} \mathrm{C}$ gave furan 138 in $71 \%$ yield. Finally, smooth oxidation of $\mathbf{1 3 8}$ with magnesium monoperoxyphthalate (MMPP) in a mixture of $i-\mathrm{PrOH}$ and water [96] (or with $m$-chloroperbenzoic acid [97]) gave racemic bromobeckerelide (132) (Scheme 49) [98].

In 1993, bromobeckerelide (131) was synthesized by Katsumura, Ichikawa and Mori by photosensitized oxidation of the trisubstituted $\alpha$-trialkylsilylfuran 139 (Figure 12), which was obtained by introduction of the required substituents into the furan ring via regioselective lithiation [100].

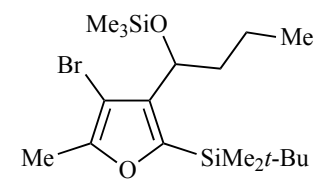

139

Figure 12. Structure of the trisubstituted $\alpha$ trialkylsilylfuran $\mathbf{1 3 9}$

Two years later, de March, Font and coworkers described a new synthesis of bromobeckerelide in which the target compound was obtained via a four-step route involving the use of methyl 2-butyl-2,3-pentadienoate (140) as the starting material (Scheme 50) [101].

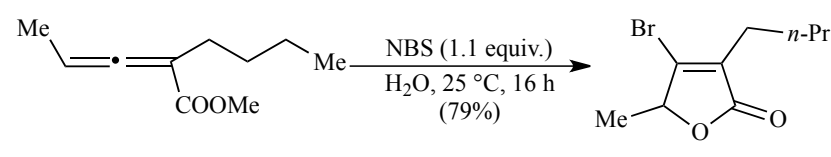

140

141
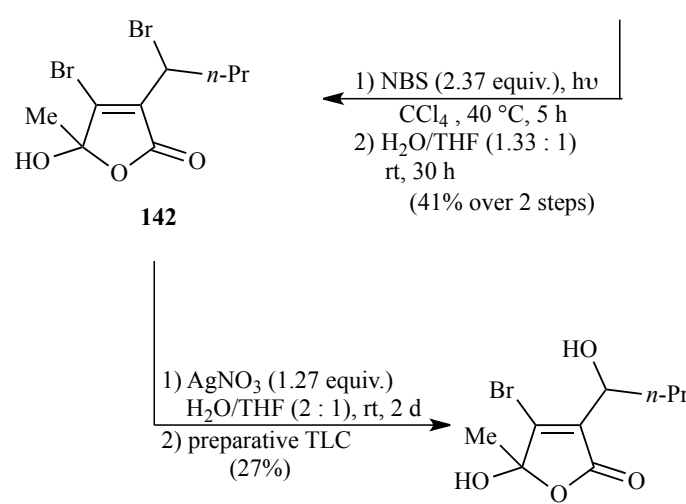

131

Scheme 50. Synthesis of bromobeckerelide (131) starting from methyl 2,3-allenoate $\mathbf{1 4 0}$

In particular, the light protected reaction of $\mathbf{1 4 0}$ with 1.1 equiv of NBS in water at $25{ }^{\circ} \mathrm{C}$ gave 4-bromo-3-butyl-5methyl-2(5H)-furanone (141) in 79\% yield. A mixture of 141 and 2.37 equiv of NBS in $\mathrm{CCl}_{4}$ was subsequently irradiated with a $500 \mathrm{~W}$ incandescent lamp at $40-45{ }^{\circ} \mathrm{C}$ and the resulting reaction mixture was filtered and concentrated and the residue was treated with a mixture 
THF and water at room temperature providing pure 4bromo-3-(1-bromobutyl)-5-hydroxy-5-methyl-2(5H)-

furanone (142) in $41 \%$ yield. The final step of this route leading to $\mathbf{1 3 1}$ in $27 \%$ yield consisted of a light-protected reaction of 142 with 1.27 equiv of $\mathrm{AgNO}_{3}$ in a mixture of THF and water for $2 \mathrm{~d}$ at room temperature, followed by TLC purification of the resulting product (Scheme 50) [101].

In 2004, Brückner and coworkers developed a regioselective route to (Z)-4-bromo-5-(trans-2-phenyl-2propenylidene)-2(5H)-furanone (147) and ( $Z$ )-4-bromo-5[1-phenyl(nethylene)]-2(5H)-furanone (149) that involved the use of levulinic acid (143) as the starting material (Scheme 51) [102]. Specifically, 3.5-dibromolevulinic acid (144) was prepared by bromination of 143 according to a protocol developed in 1997 by Read and coworkers [103]. The subsequent reaction of $\mathbf{1 4 4}$ with concd. sulfuric acid gave (Z)-4-bromo-5-(bromomethylene)-2(5H)-furanone (145) (C-30) in $41 \%$ yield. A $\mathrm{Pd}(\mathrm{dba})_{2} / \mathrm{AsPh}_{3}$-catalyzed Stille-type cross-coupling reaction between 145 and $(E)$-2phenylethenyltributyltin (146) then produced compound 147 in $52 \%$ yield. On the other hand, a $\mathrm{Pd}(\mathrm{dba})_{2} / \mathrm{AsPh}_{3}-$ catalyzed Stille-type reaction of $\mathbf{1 4 5}$ with phenyltributyltin (30b) in $\mathrm{THF}$ at $65^{\circ} \mathrm{C}$ for $9 \mathrm{~h}$ gave compound 148 in $47 \%$ yield (Scheme 51) [102]

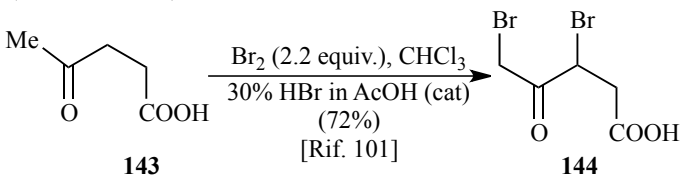

143 [Rif. 101]

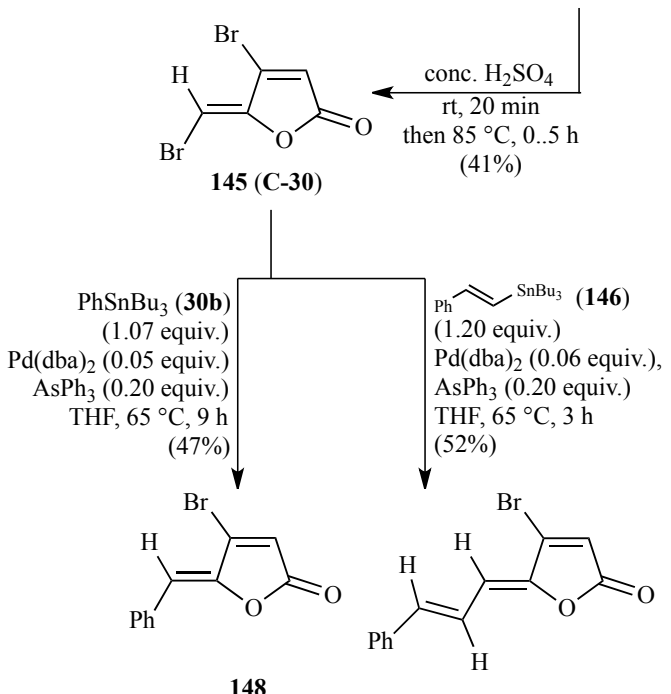

148

147

Scheme 51. Regioselective synthesis of compounds 147 and 148

In 2009, Kumar and coworkers reported that (Z)-4bromo-5-(2-methylpropylidene)-2(5H)-furanone (151a) and (Z)-4-bromo-5-(2,2-dimethylpropylidene)-2(5H)furanone (151b) were available in 54 and $25 \%$ yield, respectively, by acid-promoted cyclization of dibromocarboxylic acids 149a and 149b, respectively (Scheme 52) [61]. The cyclization reaction was postulated to proceed via dehydration of the intermediate $(Z)-3$ bromo-4-oxo-2-alkenoic acids (150) [61].<smiles>[R]C([X])(C)CC(=O)C(Br)C(Br)C(=O)O</smiles>

$$
\begin{aligned}
& \text { 149a }: \mathrm{R}=\mathrm{H} \\
& \text { 149b: } \mathrm{R}=\mathrm{Me} \\
& \qquad \begin{array}{l}
18 \mathrm{M} \mathrm{H}_{2} \mathrm{SO}_{4} \\
\mathrm{CH}_{2} \mathrm{Cl}_{2}, \text { reflux }
\end{array}
\end{aligned}
$$<smiles>[R]C(C)(C)CC(=O)/C(Br)=C/C(=O)O</smiles>

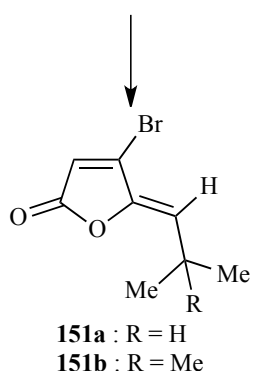

Scheme 52. Synthesis of (Z)-4-bromo-5-ylidene-2(5H)furanones 151a,b

In the same year, Laschat and coworkers described an efficient synthesis of an $80: 20$ diastereomeric mixture of $(5 R)$ - and (5S)-4-bromo-3-methyl-5-[(1R,3R,5R)-1,3,5trimethyloctyl]-2(5H)-furanone, (155a) and (155b), respectively [104], starting from the known preengland wax-derived methyl (2E,4R,6R,8R)-2,4,6,8tetramethylundec-2-enaote (152) (Scheme 53) [105]. Compound 152 was submitted to ozonolysis with reductive work-up with $\mathrm{PPh}_{3}$ according to the method of Herber and Breit [106] providing aldehyde $\mathbf{1 5 3}$ in $75 \%$ yield. Compound 153 was then reacted with (E)-3bromomethacrylic acid (154) in the presence of $n$-BuLi in THF at $-78^{\circ} \mathrm{C}$ according to the procedure of Williams and coworkers [107] yielding an $80: 20$ diastereomeric mixture of compounds $\mathbf{1 5 5 \mathbf { a }}$ and $\mathbf{1 5 5 b}$, which were separated by chromatography and isolated in $54 \%$ and $14 \%$ yield, respectively. Compound $\mathbf{1 5 5 b}$ was then used as direct precursor to (+)-capensifuranone (156) [104], the enantiomer of a compound that, in 1995, was isolated from Siphonaria capensis, a genus of cur-breathing sea snails from the South-East coast of South Africa [108]. In fact, the reaction of $\mathbf{1 5 5} \mathrm{b}$ with 5.0 equiv of dimethylzinc in a mixture of toluene and THF at $0{ }^{\circ} \mathrm{C}$ in the presence of 10 
mol\% $\mathrm{Pd}\left(\mathrm{PPh}_{3}\right)_{4}$ gave 156 in $88 \%$ yield (Scheme 53 ) [104].<smiles>CCC[C@H](C)C[C@@H](C)C[C@@H](C)C=C(C)C(=O)OC</smiles><smiles>CCC[C@@H](C)C[C@@H](C)C[C@H](C)C1OC(=O)C(C)=C1Br</smiles>

155a $(54 \%)$
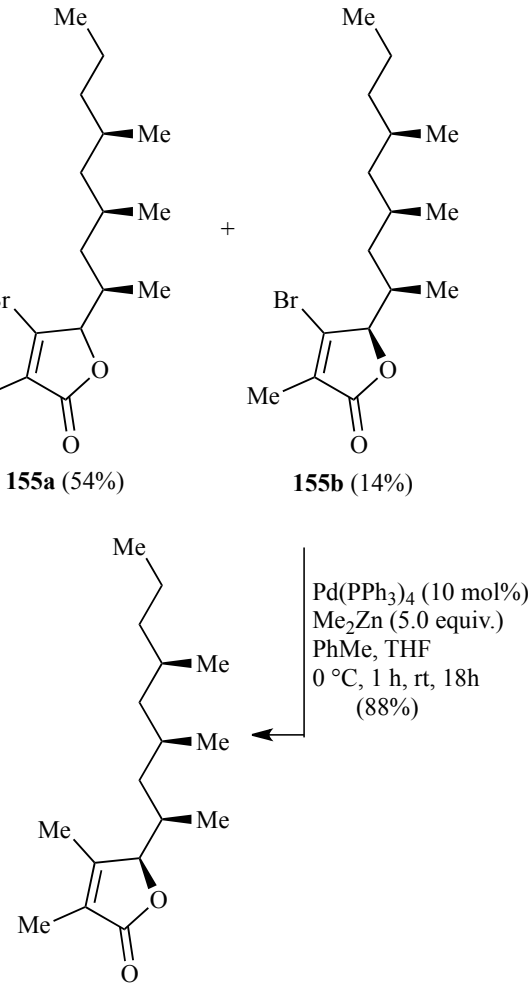

156

Scheme 53. Synthesis of 4-bromo-2(5H)-furanones 155a and $155 b$ and $(+)$-capensifuranone (156)

In 2010, De Keersmaecker and coworkers synthesized 4-bromo-3-hexyl-5-methylene-2 $(5 H)$-furanone (159) in $12 \%$ yield by using a three-step protocol in which $n$ hexylmaleic anhydride (157) was the starting material
(Scheme 54) [109]. In particular, the reaction of 157 with 1.1 equiv of methylmagnesium iodide in $\mathrm{Et}_{2} \mathrm{O}$ at $-20{ }^{\circ} \mathrm{C}$ and then at room temperature gave regiospecifically compound $\mathbf{1 5 8}$ in $50 \%$ yield. The subsequent addition of bromine to $\mathbf{1 5 8}$ followed by dehydration and dehydrobromination with pyridine in $\mathrm{CHCl}_{3}$ at room temperature gave compound $\mathbf{1 5 9}$ in $24 \%$ yield. Notably, this compound was found capable to inhibit Salmonella typhimurium strain ATCC14028 biofilm formation by $50 \%$ at a concentration of 100-250 $\mu \mathrm{M}$. In addition, it was also found able to inhibit the QS regulated bioluminescence of Vibrio harveyi $\mathrm{BB} 120$ with an $\mathrm{IC}_{50}$ of $1.357 \mu \mathrm{M}$ [109].

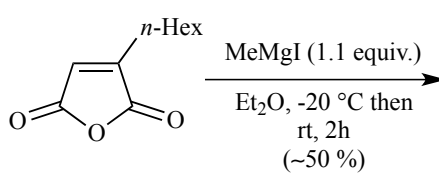

157

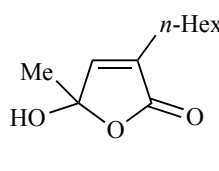

158

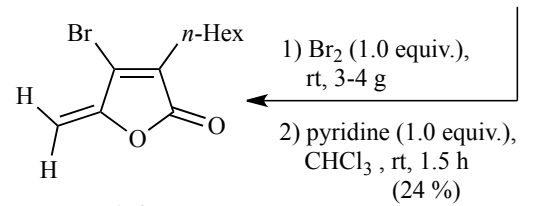

159

Scheme 54. Synthesis of 4-bromo-3-hexyl-5methylene-2(5H)-furanone (159)

\subsection{SYNTHESIS OF 5-BROMO-2(5H)-FURANONE DERIVATIVES}

In 1952, racemic 5-bromo-2(5H)-furanone (161) was synthesized in $81 \%$ yield by the reaction of 2-acetoxyfuran (160) with an equimolar amount of bromine in $\mathrm{CCl}_{4}$ at $-5 \sim$ $-10^{\circ} \mathrm{C}$ followed by distillation of the resulting low boiling products (Scheme 55) [110].

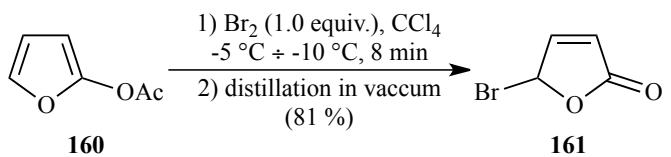

Scheme 55. Synthesis of racemic 5-bromo-2(5H)furanone (161) from 2-acetoxyfuran (160)

In 1973, compound 161 was prepared in $91 \%$ yield by treatment of 5-hydroxy-2(5H)-furanone (162) with 1.03 equiv of pyrocatechol phosphorous tribromide in $\mathrm{CH}_{2} \mathrm{Cl}_{2}$ under reflux for $1.8 \mathrm{~h}$ in the presence of molecular sieves (Scheme 56) [111].

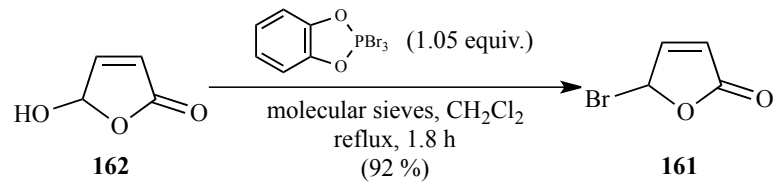


Scheme 56. Synthesis of racemic 5-bromo-2(5H)furanone (161) from 5-hydroxy-2(5H)-furanone (162)

On the other hand, 5-bromo-4-ethyl-3-methyl-2(5H)furanone (164) was obtained in quantitative yield by treatment of 4-ethyl-3-methyl-5-hydroxy-2 $(5 H)$-furanone (163) with glacial acetic acid containing $\mathrm{HBr}$ gas $(40 \%$ by weight) for $5 \mathrm{~d}$ at room temperature (Scheme 57) [111].

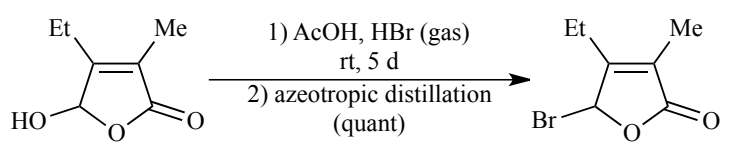

163
Scheme 57. Synthesis of 5-bromo-4-ethyl-3-methyl2(5H)-furanone (164)

In 1965, 5-bromo-4-phenyl-2(5H)-furanone (166) and 5-bromo-3-methyl-4-phenyl-2(5H)-furanone (168) were synthesized in $60.9 \%$ and $98.2 \%$ yield, respectively, by treatment of the corresponding 5-unsubstituted 2(5H)furanones 165 and 167, respectively, with 1.02-1.05 equiv of NBS in $\mathrm{CCl}_{4}$ under reflux (Scheme 58, eqs. a and b) [112]. The bromination reaction of $\mathbf{1 6 5}$, unlike that of $\mathbf{1 6 7}$, was carried out in the presence of a catalytic amount of AIBN. It was also described that the reaction of 3,4dimethyl-2(5H)-furanone (169) with 1.0 equiv of NBS in $\mathrm{CCl}_{4}$ under reflux gave 5-bromo-3,4-dimethyl-2(5H)furanone (170) (Scheme 58, eq. c) [112]. However, unfortunately, the yield of this reaction was not reported. a)

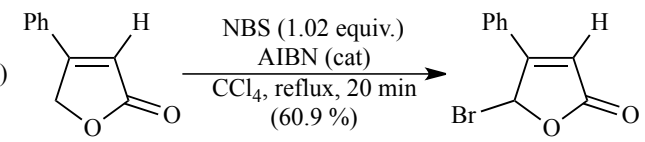

165

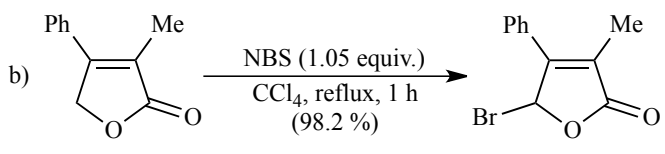

167

168

c)

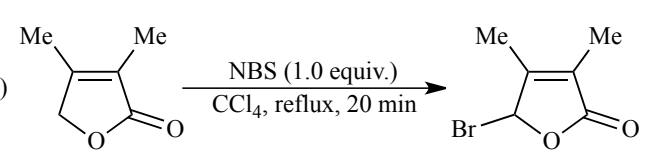

169
Scheme 58. Synthesis of 5-bromo-2(5H)-furanones 166, 168 and 170

In 1976, 5-bromo-4-methyl-2(5H)-furanone (172) was prepared in $89 \%$ yield by reacting 4-methyl-2(5H)furanone (171) with 1.08 equiv of $\mathrm{NBS}$ in $\mathrm{CCl}_{4}$ under reflux and irradiation with a $100 \mathrm{~W}$ lamp (Scheme 59) [113].

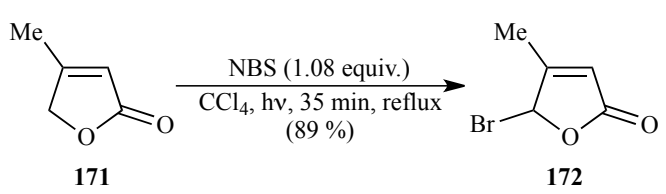

Scheme 59. Synthesis of 5-bromo-4-methyl-2(5H)furanone (172)

Two years later, Pettit and coworkers described that methyl 2-aryl-4-oxobutanoates $\mathbf{1 7 4 a}$ and $\mathbf{1 7 4 b}$, which were prepared via a multi-step sequence from the corresponding arylacetic acids $\mathbf{1 7 3 a}$ and $\mathbf{1 7 3 b}$ respectively, underwent reaction with an equimolar amount of bromine in glacial acetic acid to produce 3-aryl-5-bromo-2 $(5 H)$-furanones 175a and 175b in $23 \%$ and $27.1 \%$ yield, respectively (Scheme 60) [114].<smiles>[R]c1ccc(CC(=O)O)cc1</smiles>

173a $: \mathrm{R}=\mathrm{Cl}$ 173b $: R=F$<smiles>CC(C)CC(C)C</smiles><smiles>[R][R](F)=[Y18]([H])C(=O)CC(C(=O)OC)c1ccc([R])cc1</smiles><smiles>O=C1OC(Br)C=C1c1ccc(Cl)cc1C1=CC(Br)OC1=O</smiles>

Scheme 60. Synthesis of 3-aryl-5-bromo-2(5H)furanones 175a and 175b

In 1989, Martin and coworkers described the synthesis of 4-alkoxy-2(5H)-furanones 98a-e from $\beta$-tetronic acid (109) and their conversion to 4-alkoxy-5-bromo-2(5H)furanones 176a-e (Scheme 61) [115]. In particular, they 
found that the reaction of $\mathbf{1 0 9}$ with 3.0 equiv of alcohols in the presence of a catalytic amount of $p$ - $\mathrm{TsOH}$, followed by removal of water by azeotropic distillation with benzene gave compounds 98 in yields ranging from 64 to $91 \%$. Subsequent bromination of compounds 98a-e with 1.05 equiv of $\mathrm{NBS}$ in $\mathrm{CCl}_{4}$ at $0{ }^{\circ} \mathrm{C}$ under irradiation with a mercury high pressure lamp led to compounds 176a-e in yields ranging from 25 to $83 \%$ (Scheme 61) [115].

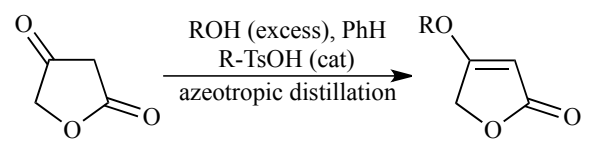

10998

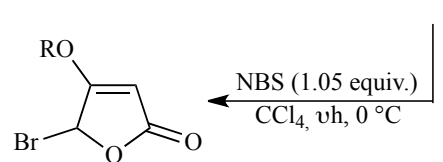

\begin{tabular}{cccc}
\multicolumn{4}{c}{$\mathbf{1 7 6}$} \\
\hline $\mathbf{1 7 6}$ & $\mathrm{R}$ & Yield\% of $\mathbf{9 8}$ & Yield\% of $\mathbf{1 7 6}$ \\
\hline $\mathbf{1 7 6 a}$ & $\mathrm{Me}$ & $81^{\text {(a) }}$ & 62 \\
$\mathbf{1 7 6 b}$ & $\mathrm{CH}_{2}=\mathrm{CH}\left(\mathrm{CH}_{2}\right)_{2}$ & 91 & 25 \\
$\mathbf{1 7 6} \mathbf{c}$ & $\mathrm{CH}_{2}=\mathrm{CHCH}_{2}$ & 81 & 31 \\
$\mathbf{1 7 6 d}$ & $\mathrm{Me}_{3} \mathrm{SiCH}_{2} \mathrm{CH}_{2}$ & 64 & 83 \\
$\mathbf{1 7 6 e}$ & $\mathrm{Me}\left(\mathrm{CH}_{2}\right)_{4}$ & 91 & 72 \\
\hline
\end{tabular}

Scheme 61. Synthesis of 4-alkoxy-5-bromo-2(5H)furanones 176a-e

Finally, in concluding this subsection we wish to point out that, at the best of our knowledge, bioactivity data of $2(5 H)$-furanones featuring only one bromine atom on the heterocyclic ring have not been reported in the literature so far.

\section{SYNTHESIS AND BIOACTIVITY OF 2(5H)- FURANONE DERIVATIVES WITH TWO BROMINE ATOMS ON THE HETEROCYCLIC RING}

Mucobromic acid (1) is a dibrominated compound which can exist in an open-chain and in a ring form called 3,4-dibromo-5-hydroxy-2(5H)-furanone (Figure 13).

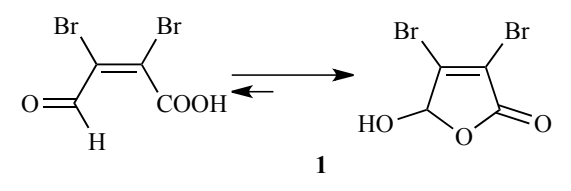

Figure 13. Chemical structure of mucobromic acid (1)

It is currently commercially available, but in the past years it was prepared by the reaction of furfural (8) [116] or 2-furoic acid (107) [117] with bromine in boiling water (Scheme 62).

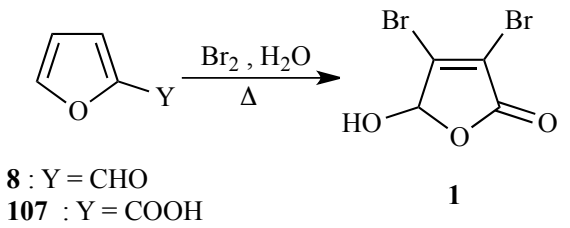

Scheme 62. Synthesis of mucobromic acid (1) from furfural (8) or 2-furoic acid (107)

In 1976, compound $\mathbf{1}$ was identified as a powerful inhibitor of tumoral and pancreatic $L$-asparagine synthetases [118] and, in 1994, it was found to be a potent bacterial mutagen with mean molar mutagenicity in the Salmonella typhimurium (TA100-S9) assay of 5.54 revertants/mmol [119].

In 2009, Marcos and coworkers [120] reported that $\mathbf{1}$, which is a by product of water disinfection especially in surface water with high amount of bromide [121], is genetoxic leading to high levels of DNA breaks. More recently, Yang and coworkers found that 1 significantly inhibits the growth of two marine diatoms Cylinthroteca sp. and Nitzschia closterium and that the effect of this compound depends on the dose and diatoms species [120]. These authors further demonstrated that $\mathbf{1}$ is a quorum sensing inhibitor against the formation of Cylinthroteca sp. biofilms [122].

3,4-Dibromo-2(5H)-furanone (2) is another dibrominated compound the synthesis of which in the past years has been the subject of significant attention $[43,53,23-126]$. However, the synthetic procedures which date back to before the 1960s [124,125] are low yielding and involve the use of commercially unavailable starting materials and/or toxic reagents. Nevertheless, as already mentioned in subsection 2.1 of this review, in 2002, Zhang and coworkers synthesized 2 in $57 \%$ yield by reduction of mucobromic acid (1) with sodium triacetoxyborohydride in $\mathrm{CHCl}_{3}$ followed by addition of acetic acid (Scheme 14) [53]. More recently, we prepared 2 in $89 \%$ yield on a multigram scale by treatment of 1 with 1.5 equiv of $\mathrm{NaBH}_{4}$ in methanol followed by addition of 1.0 equiv of concd. sulfuric acid (Scheme 63) [126].

Lalonde and Leo had previously found that in the Salmonella typhimurium (TA100) assay compound $\mathbf{2}$ had a mean molar mutagenicity value of 1.18 revertants/nmol, lower than that of mucobromic acid (1) (5.54 revertants/nmol) [119].

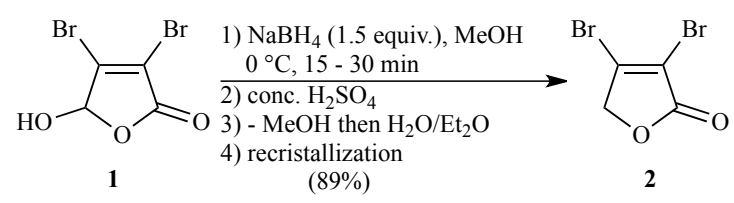


Scheme 63. Synthesis of 3,4-dibromo-2(5H)-furanone (2) via reduction of mucobromic acid (1) with $\mathrm{NaBH}_{4}$

In 2003, 5-allyl-3,4-dibromo-2(5H)-furanones 178a-c were synthesized in good yields by Zhang and coworkers via indium-mediated reaction of mucobromic acid (1) with 1.2 equiv of allyl bromides $\mathbf{1 7 7} \mathbf{a}-\mathbf{c}$ in a $1: 1$ mixture of THF and water in the presence of $10 \mathrm{~mol}_{0} \mathrm{NH}_{4} \mathrm{Cl}$ (Scheme 64) [127].

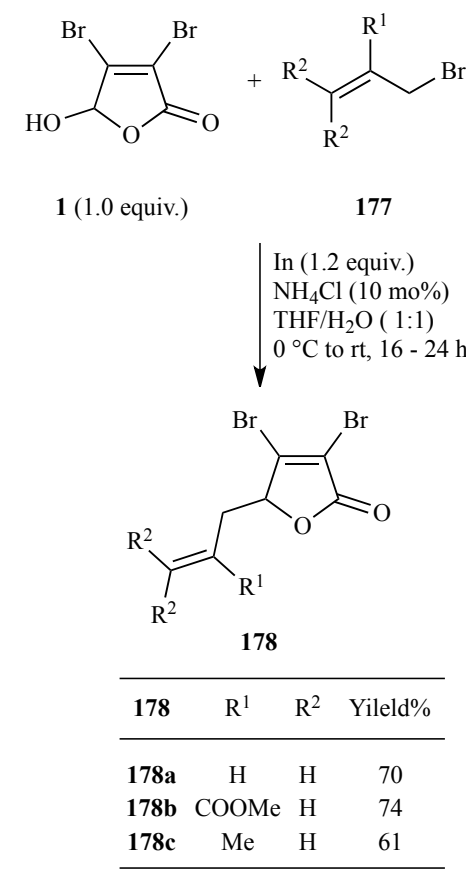

Scheme 64. Synthesis of 5-allyl-3,4-dibromo-2(5H)furanones $178 \mathbf{a}-\mathbf{c}$

Interestingly, compounds $\mathbf{1 7 8 a}$ and $\mathbf{1 7 8 c}$ were also prepared in $75 \%$ and $41 \%$ yield, respectively, by treatment of 1 with the required allyl bromides in the presence of 10 mol\% $\mathrm{NH}_{4} \mathrm{Cl}$ and 1.2 equiv of tin, a metal much less expensive than indium, in a $1: 1$ mixture of THF and water [127].

Two years later, Zhang and coworkers described that the synthesis of 5-substituted-3,4-dibromo-2 $(5 H)$ furanones of general formula $\mathbf{1 8 0}$ could be accomplished in good yields by the reaction of 1 with equimolar amounts of active methylene compounds 179 and $5 \mathrm{~mol} \% \mathrm{In}(\mathrm{OAc})_{3}$ in toluene under reflux, with water separation by a DeanStark apparatus (Scheme 65) [128]. Various Lewis acids different from $\operatorname{In}(\mathrm{OAc})_{3}$ were tested, but the latter compound turned out to be the most efficient catalyst [128].

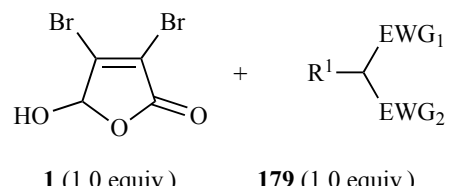

$\mathrm{In}(\mathrm{OAc})_{3}(5 \mathrm{~mol} \%)$ PhMe, reflux $\left(-\mathrm{H}_{2} \mathrm{O}\right)$<smiles>[R]C([Y10])([AlH2])C1OC(=O)C(Br)=C1Br</smiles>

180

\begin{tabular}{ccccc}
\hline $\mathbf{1 8 0}$ & EWG $^{1}$ & EWG $^{2}$ & $\mathrm{R}^{1}$ & Yield\% \\
\hline 180a & COOEt & COOEt & $\mathrm{H}$ & 89 \\
$\mathbf{1 8 0 b}$ & COO $i$-Pr & COO $i$-Pr & $\mathrm{H}$ & 91 \\
$\mathbf{1 8 0 c}$ & COOEt & COOBn & $\mathrm{H}$ & 89 \\
$\mathbf{1 8 0 d}$ & $\mathrm{COOEt}$ & $\mathrm{COOEt}$ & $\mathrm{Me}$ & 78 \\
$\mathbf{1 8 0 e}$ & $\mathrm{H}$ & $\mathrm{H}$ & $\mathrm{COOH}$ & 60 \\
$\mathbf{1 8 0 g}$ & $\mathrm{COO} n$-Oct & $\mathrm{CN}$ & $\mathrm{H}$ & 69 \\
& & & & \\
\hline
\end{tabular}

Scheme 65. Synthesis of compounds 180a-f

Zhang and coworkers also reported that the Mukaiyama aldol reaction of $\mathbf{1}$ with methyl trimethylsilyl dimethylketeneacetal $(\mathbf{1 8 1})$ in toluene at $-20{ }^{\circ} \mathrm{C}$ for $2 \mathrm{~h}$ and then at room temperature for $16 \mathrm{~h}$ in the presence of 10 $\mathrm{mol} \% \mathrm{ZnCl}_{2}$, followed by hydrolysis gave compound $\mathbf{1 8 2}$ in $75 \%$ yield (Scheme 66) [129].

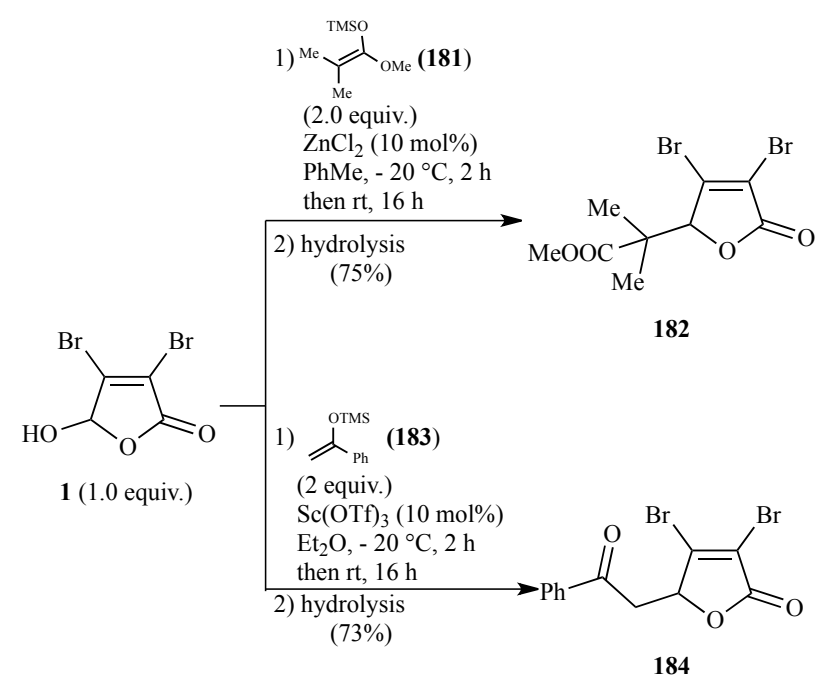

Scheme 66. Synthesis of compounds 182 and 184

Moreover, they found that an analogous $\mathrm{Sc}(\mathrm{OTf})_{3}-$ catalyzed Mukaiyama aldol reaction between 1 and 1phenyl-1-(trimethylsilyloxy)ethylene (183) in $\mathrm{Et}_{2} \mathrm{O}$ at -20 ${ }^{\circ} \mathrm{C}$ for $2 \mathrm{~h}$ and then at room temperature for $16 \mathrm{~h}$ followed by hydrolysis produced 5-(benzoylmethyl)-3,4-dibromo$2(5 H)$-furanone $(\mathbf{1 8 4})$ in $73 \%$ yield [129]. 
In 2007, in continuation of their studies on the selective synthesis of 5-substituted 3,4-dihalo-2(5H)-furanones, Zhang and coworkers synthesized 5-aryl-3,4-dibromo$2(5 H)$-furanones $\mathbf{1 8 5}$ via $\operatorname{In}(\mathrm{OTf})_{3}$-catalyzed FriedelCrafts-type reaction between 1.0 equiv of 1 with 1.5 equiv of electron-rich arenes in toluene under reflux.[130] This protocol allowed the synthesis of compound 185a, 185b and $185 \mathrm{c}$ in $71 \%, 82 \%$ and $45 \%$ yield, respectively (Scheme 67) [130].

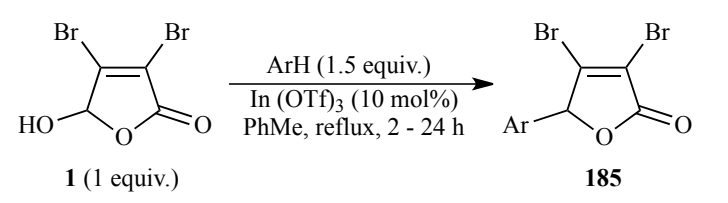

\begin{tabular}{ccc}
\hline $\mathbf{1 8 5}$ & Ar & Yield $\%$ \\
\hline $\mathbf{1 8 5 a}$ & $2,3,4-(\mathrm{MeO})_{3} \mathrm{C}_{6} \mathrm{H}_{2}$ & 71 \\
$\mathbf{1 8 5 b}$ & $2,3,6-(\mathrm{MeO}){ }_{3} \mathrm{C}_{6} \mathrm{H}_{2}$ & 82 \\
$\mathbf{1 8 5 c}$ & $2,4,5-(\mathrm{MeO}){ }_{3} \mathrm{C}_{6} \mathrm{H}_{2}$ & 45 \\
\hline
\end{tabular}

Scheme 67. Synthesis of 5-aryl-3,4-dibromo-2(5H)furanones 185a-c

The same research group described that a $5: 1 \mathrm{syn} / \mathrm{anti}$ steroisomeric mixture of 3,4-dibromo-5[hydroxy(phenyl)methyl]-2(5H)-furanone (187a) was available in $87 \%$ yield by direct vinylogous aldol reaction of 3,4-dibromo-2(5H)-furanone (2) with benzaldehyde (127) in methanol at room temperature in the presence of 0.5 equiv of $\mathrm{Et}_{3} \mathrm{~N}$ (Scheme 68) [131].

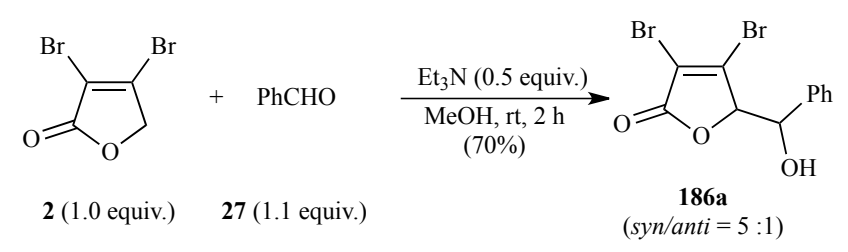

Scheme 68. Synthesis of 3,4-dibromo-5[hydroxy(phenyl)methyl]-2(5H)-furanone (186a)

In 2010, Terada and coworkers reported the first enantioselective direct vinylogous reaction of $\mathbf{2}$ with aryl aldehydes [42]. The method, which involved the reaction of 2 with 1.2 equiv of aryl aldehydes in a $1: 1$ mixture of acetone and THF at $-40{ }^{\circ} \mathrm{C}$ in the presence of $5 \mathrm{~mol} \%$ the axially chiral guanidine base $(\boldsymbol{R})-\mathbf{G b}$, enabled efficient access to optically active compounds 186a-f (Scheme 69) [42].
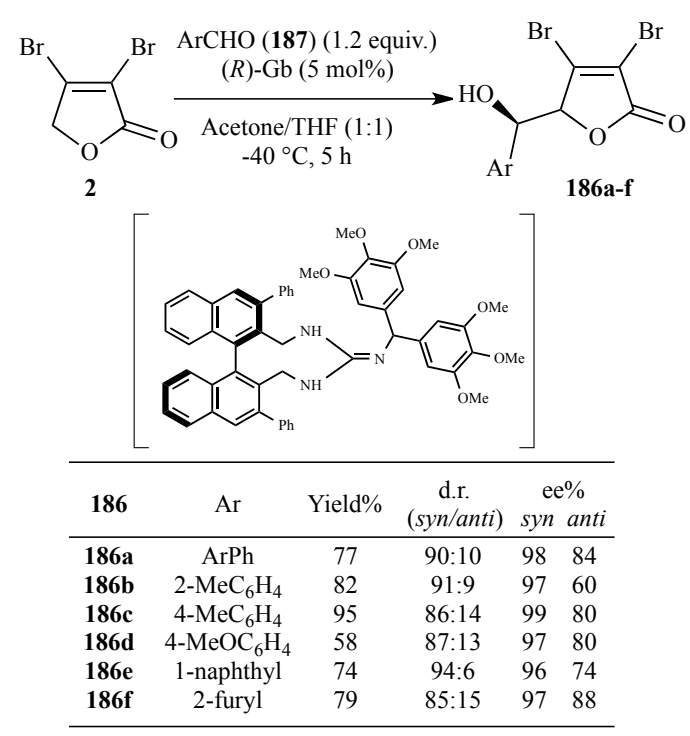

Scheme 69. Enantioselective synthesis of compounds 186a-f

These 3,4-dibromo-5-[hydroxy(phenyl)methyl]-2(5H)furanones were obtained in high diastereoselectivity with excellent enantioselectivity for the major $s y n$-stereoisomers [42].

In 2012, W.-M. Chen and coworkers synthesized stereoisomeric mixtures of 5-(arylmethylene)-3,4-dibromo$2(5 H)$-furanones 188a and $\mathbf{1 8 8 b}$ in $60 \%$ and $61 \%$ yield, respectively, by treatment of racemic syn/anti mixtures of compounds 186a and 186b with concd. sulfuric acid in methanol at $76^{\circ} \mathrm{C}$ for $8 \mathrm{~h}$ (Scheme 70) [132].

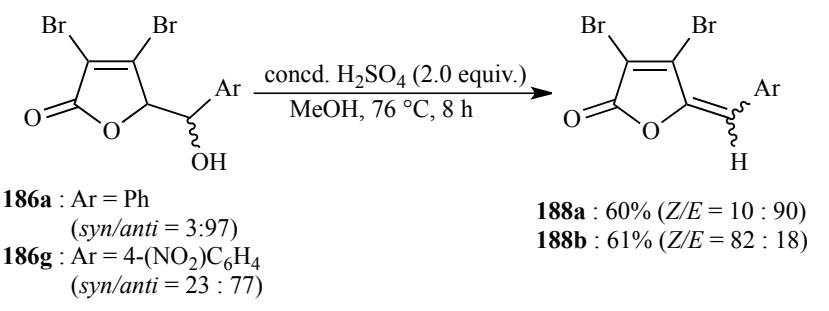

Scheme 70. Synthesis of 5-(arylmethylene)-3,4dibromo-2(5H)-furanones $\mathbf{1 8 8 a}$ and $\mathbf{1 8 8 b}$

These authors also synthesized 3,4-dibromo-5-[(2furyl)methylene]-2(5H)-furanone (188c) and 3,4-dibromo5-[(2-thienyl)methylene]-2(5H)-furanone (188d) in 39 and $40.5 \%$ yield, respectively, by treatment of 2 with 1.1 equiv of the required heteroaryl aldehydes in methanol at room temperature in the presence of $10 \quad \mathrm{~mol}_{\%} \quad \mathrm{Et}_{3} \mathrm{~N}$, concentration of the resulting reaction mixtures and washing the residues with $5 \% \mathrm{HCl}$ (Scheme 71) [132]. 


$$
\begin{aligned}
& \mathrm{Br} \quad \mathrm{Br} \quad \text { 1) } \mathrm{ArCHO}(187) \text { (1.1 equiv.) } \\
& \sum_{\mathrm{O}}^{\mathrm{Br}} \frac{\begin{array}{l}
\mathrm{MeOH}, \mathrm{rt}, 4 \mathrm{~h} \\
\text { 2) concentration and } \\
\text { treatment with } 5 \% \mathrm{HCl}
\end{array}}{\mathrm{Et}_{3} \mathrm{~N}(10 \mathrm{~mol} \%)} \\
& 2 \text { (1.0 equiv.) }
\end{aligned}
$$

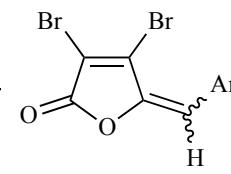

Scheme 71. Synthesis of compounds $188 \mathrm{c}$ and $\mathbf{1 8 8 d}$ from 3,4-dibromo-2 $(5 H)$-furanone (2)

They finally synthesized 3,4-dibromo-5-(4hydroxyphenyl)methylene]-2(5H)-furanone (188e) in $29 \%$ yield by the reaction of $\mathbf{2}$ with 1.2 equiv of 4 hydroxybenzaldehyde (187) and $20 \mathrm{~mol} \%$ piperidine in methanol under reflux for $1.5 \mathrm{~h}$ under nitrogen atmosphere and concentration in vacuo of the resulting reaction mixture (Scheme 72) [132].

Notably, compounds $\mathbf{1 8 8}$ a and $\mathbf{1 8 8 c}$ were found capable to exhibit remarkable effect of biofilm formation inhibition on Pseudomonas aeruginosa [130], a Gram-negative opportunistic pathogenic bacterium which colonizes most wounds forming biofilms making ineffective the clearance by immune defensive systems and antibiotherapy, thus causing wounds unhealed [133-135].<smiles>O=C1OCC(Br)=C1Br</smiles>
2 (1.0 equiv.) (1)<smiles>O=C1O/C(=C\c2ccc(O)cc2)C(Br)=C1Br</smiles>

188e (E/Z n.d.)

Scheme 72. Synthesis of compound 188e

In 2011, Ramachandran and Sreekumar carried out the synthesis of the 3,4-dibromo-2 $(5 H)$-furanone derivatives 2 , 189, 190 and 191 starting from mucobromic acid (1) via the one-step reactions depicted in Scheme 73 [136]. They also tested the antibacterial activity of these substances against Escherichia coli, Proteus vulgaris, Pseudomonas aeruginosa, and Staphylococcus aureus and found that all synthesized compounds showed comparable activity against the Gram-negative bacteria E. coli, P. vulgaris, and P. aeruginosa [136].<smiles>O=C1OCC(Br)=C1Br</smiles>
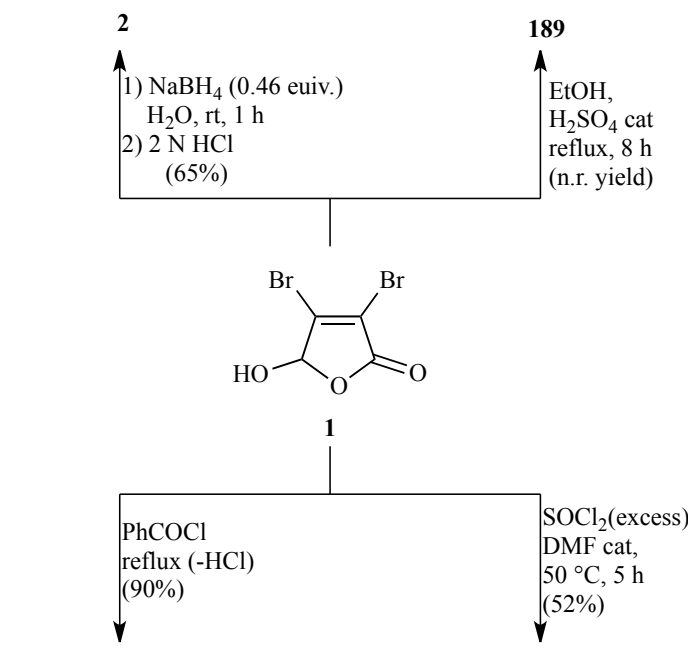<smiles>O=C1OC(CC(=O)c2ccccc2)C(Br)=C1Br</smiles>

190<smiles>CCOC1OC(=O)C(Br)=C1Br</smiles>

191
Scheme 73. Synthesis of compounds 2, 189, 190 and 191 from mucobromic acid (1)

Finally, in 2015, Barbosa and coworkers synthesized (Z)-5-(arylmethylene)-3,4-dibromo-2(5H)-furanones $\mathbf{1 8 8 f -}$ i and evaluated the photosynthesis inhibition properties of these substances [78]. As outlined in Scheme 74, compounds $\mathbf{1 8 8 f}-\mathbf{i}$ were obtained in modest to satisfactory yields via aldol condensation of $\mathbf{2}$ with the required aryl aldehydes in $\mathrm{CH}_{2} \mathrm{Cl}_{2}$ solution in the presence of TBDMSOTf and $i$ - $\mathrm{Pr}_{2} \mathrm{NEt}$.

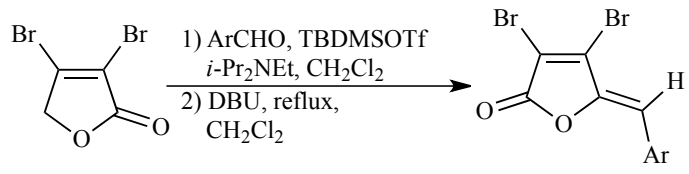

2

188f : $\mathrm{Ar}=4-\mathrm{FC}_{6} \mathrm{H}_{4}(14 \%)$ 188g: $\mathrm{Ar}=4-\mathrm{CF}_{3} \mathrm{C}_{6} \mathrm{H}_{4}(31 \%)$ 188h : $\mathrm{Ar}=4-\mathrm{EtC}_{6} \mathrm{H}_{4}(47 \%)$ 188i : $\mathrm{Ar}=3-\mathrm{MeOC}_{6} \mathrm{H}_{4}(67 \%)$

Scheme 74. Synthesis of (Z)-5-(arylmethylene)-3,4dibromo-2(5H)-furanones $\mathbf{1 8 8 f - \mathbf { i }}$

The resulting adducts, which were not isolated, were treated with $\mathrm{DBU}$ in $\mathrm{CH}_{2} \mathrm{Cl}_{2}$ under reflux providing compounds 188f, 188g, 188h and 188i in 14, 31, 47, and $67 \%$ yield, respectively. Remarkably, among these compounds, $\mathbf{1 8 8 g}$ bearing the strong electron-withdrawing $\mathrm{CF}_{3}$ group showed the highest photosynthesis inhibitory 
activity and $\mathbf{1 8 8 f}$ exhibited greater activity than $\mathbf{1 8 8 h}$ in uncoupled electron flux [78].

4. SYNTHESIS AND BIOACTIVITY OF 2(5H)FURANONE DERIVATIVES FEATURING ONE BROMINE ATOM ON THE HETEROCYCLIC RING AND MONOBROMINATED SUBSTITUENTS

In 1982, 3-bromo-5-bromomethyl-2(5H)-furanone (193) was prepared in $8.5 \%$ yield by Font and coworkers via addition of 1.96 equiv of bromine to a stirred solution of 1.0 equiv of $(E)$-2,4-pentadienoic acid (192) and 10.2 equiv of $\mathrm{NaHCO}_{3}$ in water at room temperature, followed by addition of $16 \mathrm{~N}$ sulfuric acid (to $\mathrm{pH}$ 2) to the resulting reaction mixture (Scheme 75) [137].

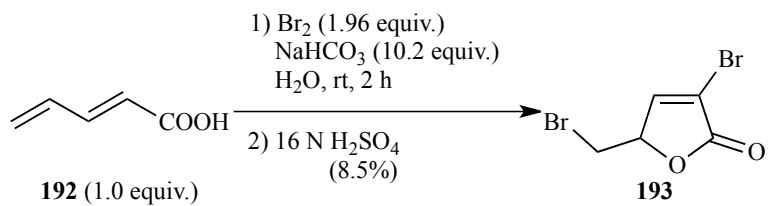

Scheme 75. Synthesis of 3-bromo-5-bromomethyl2(5H)-furanone (193)

The same authors also synthesized 5-bromo-5bromomethyl-2(5H)-furanone (195) in 54\% yield by treatment of 5-bromomethyl-2(5H)-furanone (194) with NBS in $\mathrm{CH}_{2} \mathrm{Cl}_{2}$ at room temperature for $4 \mathrm{~h}$ (Scheme 76) [137].

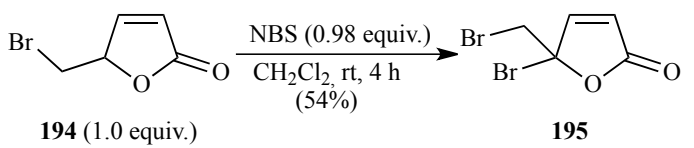

Scheme 76. Synthesis of 5-bromo-5-bromomethyl2(5H)-furanone (195)

In 1979, Beechan and Sims concisely described the first total synthesis of (Z)-4-bromo-5-(bromomethylene)-3butyl-2(5H)-furanone (196) (Figure 14) [138], a naturally occurring fimbrolide isolated from the marine red alga Delisea pulchra [139-141] and Delisea elegans [142].<smiles>CCCC1=C(Br)/C(=C/Br)OC1=O</smiles><smiles>[R]C(=O)NC1CCOC1=O</smiles>

Figure 14. Structures of compounds 196 and AHLs

The synthesis of this natural compound, which has structural similarity to $\mathrm{N}$-acyl homoserine lactones (AHLs) (Figure12), the most common quorum sensing (QS) signals in Gram-negative bacteria [143], commenced with the
EtONa-mediated alkylation of ethyl acetoacetate (198) with commercially available ethyl 2-bromohexanoate (199) in EtOH under reflux (Scheme 77).

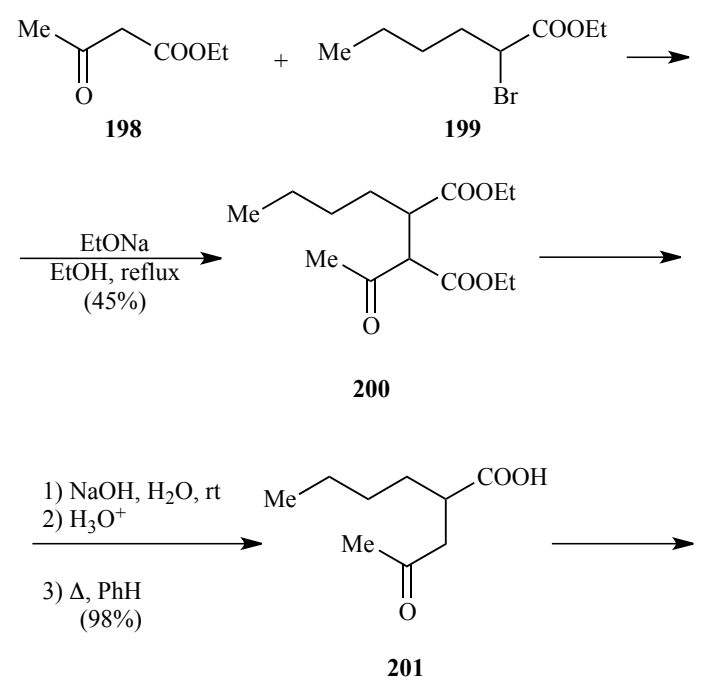<smiles>CCCCC(C(=O)O)C(Br)C(=O)CBr</smiles><smiles>CCCCC1=C(Br)/C(=C\Br)OC1=O</smiles>

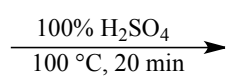<smiles>CCCCC1=C(Br)/C(=C\Br)OC1=O</smiles>

28\% yield of $\mathbf{1 9 6}$ based on $\mathbf{2 0 1}$ $(\mathbf{1 9 6 / 2 0 3}=99.3: 0.3)$

Scheme 77. First total synthesis of natural furanone 196

The reaction gave compound $\mathbf{2 0 0}$ in $45 \%$ yield, which was converted to $\gamma$-ketoacid $\mathbf{2 0 1}$ by hydrolysis followed by decarboxylation of the resulting unstable dicarboxylic acid. Bromination of 201 in $\mathrm{CHCl}_{3}$ solution according to the literature [144] gave crude dibromocarboxylic acid 202, which on treatment with $40 \%$ sulfuric acid at $100{ }^{\circ} \mathrm{C}$ provided compound 196 in $28 \%$ yield based on 201. As shown in Scheme 77, compound 196 was obtained together with a small amount of $(E)$-4-bromo-5-(bromomethylene)3-butyl-2(5H)-furanone (203) [138], a natural product 
which was isolated from D. pulchra [57,139] and $D$. elegans [142].

Another multi-step total synthesis of compound 196 was described in 1985 by Caine and Ukuchukvu (Scheme 78) [148]. It began with the addition of bromine to methyl 2butylpropenoate (204).<smiles>C=C(CCCC)C(=O)OC</smiles>

204

205
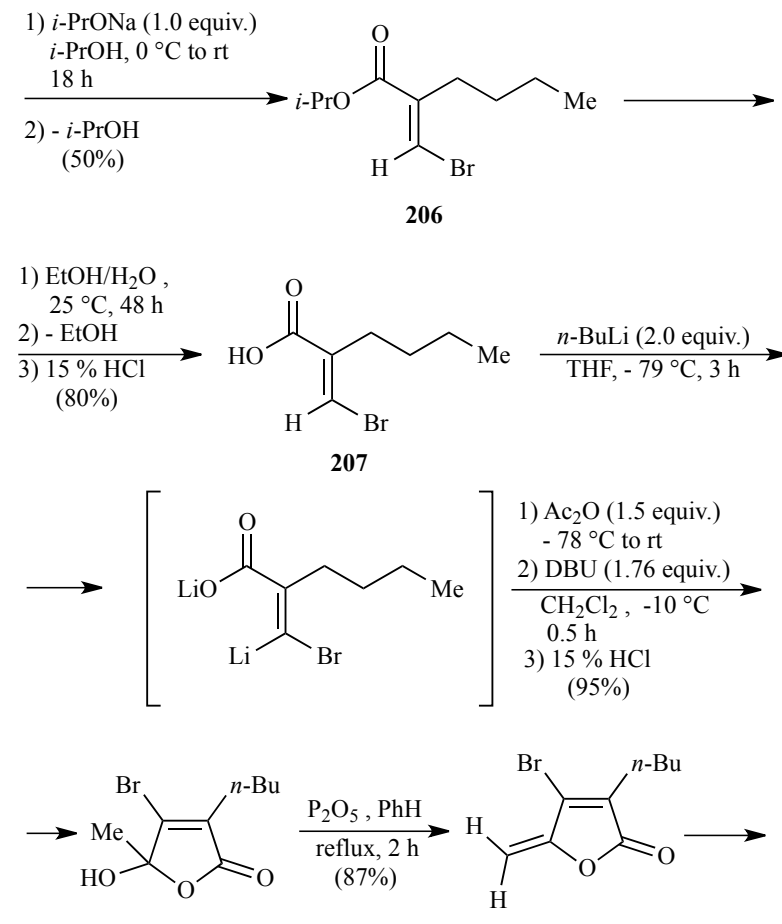

208

209

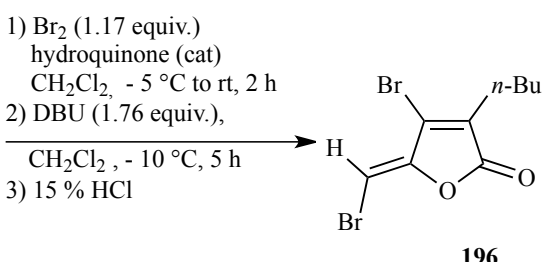

196

Scheme 78. Total synthesis of compound 196 starting from ester 204

The resulting compound was dehydrobrominated by treatment with $i$-PrONa in $i$-PrOH affording compound 206 in $50 \%$ yield. The latter was converted in high yield to the corresponding carboxylic acid $\mathbf{2 0 7}$ by treatment with aqueous $\mathrm{EtOH}$ at $25{ }^{\circ} \mathrm{C}$ for $48 \mathrm{~h}$ and removal of $\mathrm{EtOH}$ followed by acidification with $15 \% \mathrm{HCl}$. Compound 207 was then reacted with 2 equiv of $n$-BuLi in THF at $-78^{\circ} \mathrm{C}$ and the resulting organolithium derivative was treated with 1.5 equiv of $\mathrm{Ac}_{2} \mathrm{O}$ in $\mathrm{THF}$ at $-78{ }^{\circ} \mathrm{C}$. Acidification of the reaction mixture with $15 \% \mathrm{HCl}$ gave $2(5 \mathrm{H})$-furanone 208 in $45 \%$ yield, which was reacted with a mixture of $\mathrm{P}_{2} \mathrm{O}_{5}$ and benzene under reflux providing 4-bromo-3-butyl-5methylene-2 $(5 H)$-furanone (209) in $87 \%$ yield. Finally, addition of bromine to $\mathbf{2 0 9}$ and dehydration of the resulting adduct with DBU in $\mathrm{CH}_{2} \mathrm{Cl}_{2}$ at $-10{ }^{\circ} \mathrm{C}$, followed by acidification with $15 \% \mathrm{HCl}$, gave the required compound 196 in $95 \%$ yield and $13.4 \%$ overall yield based on ester 204 (Scheme 78) [148].

In 1997, Read and coworkers reinvestigated the cyclization reaction of crude dibromocarboxylic acid $\mathbf{2 0 2}$ with $100 \%$ sulfuric acid and found that the reaction at 110 $120{ }^{\circ} \mathrm{C}$ for 20 min produced five products, compound 196 (which was erroneously called E-configured), 3-butyl-5(dibromomethylene)-2(5H)-furanone (210), 4-bromo-3butyl-5-(dibromomethylene)-2(5H)-furanone (211), 5(bromomethyl)-3-butyl-4,5-dibromo-2(5H)-furanone (212), and 4-bromo-3-butyl-5-(dibromomethyl)-2( $5 H)$-furanone (213) in $21 \%, 17 \%, 14 \%, 6 \%$, and $5 \%$ yield, respectively (Scheme 79) [103]<smiles>CCCCC(C(=O)O)C(Br)C(=O)CBr</smiles>

202

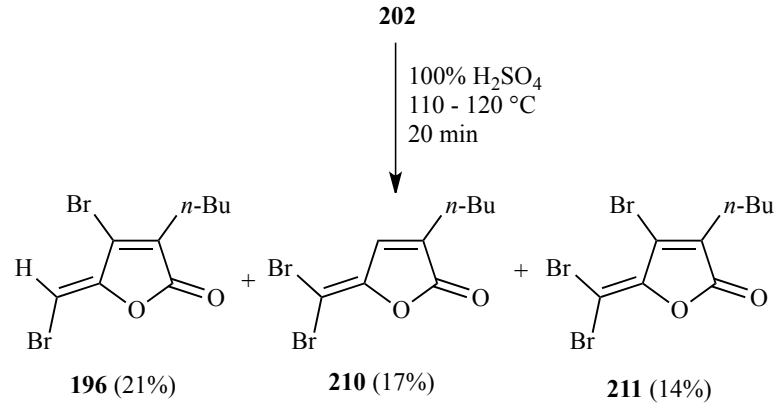<smiles></smiles>

Scheme 79. Products obtained by cyclization of crude 202 with $100 \%$ sulfuric acid

Read and coworkers also reported that the reaction of 2ethyl-4-oxopentanoic acid (214) with 2.2 equiv of bromine in $\mathrm{CHCl}_{3}$ at $50{ }^{\circ} \mathrm{C}$, followed by treatment of the resulting crude dibromoacid with $100 \%$ sulfuric acid at $110-120{ }^{\circ} \mathrm{C}$ for $20 \mathrm{~min}$ gave a mixture of (Z)-4-bromo-5(bromomethylene)-3-ethyl-2(5H)-furanone (215), 3-ethyl5-(dibromomethylene)-2(5H)-furanone (216) and 4-bromo- 
5-(dibromomethylene)-3-ethyl-2(5H)-furanone (217) from which compounds 215, 216 and 217 were isolated in $42 \%$, $17 \%$ and $5 \%$ yield, respectively (Scheme 80) [103].<smiles>CCC(CC(C)=O)C(=O)O</smiles>

214

1) $\mathrm{Br}_{2}$ (2.2 equiv.), $\mathrm{CHCl}_{3}$ $50^{\circ} \mathrm{C}, 0.5 \mathrm{~h}$ then $1 \mathrm{~h}$ reflux 2) $100 \% \mathrm{H}_{2} \mathrm{SO}_{4}, 110-120^{\circ} \mathrm{C}$ $\downarrow 20 \mathrm{~min}$<smiles>CCC1=C(Br)/C(=C\Br)OC1=O</smiles>

$215(42 \%)$<smiles></smiles>

$$
216(17 \%)
$$

$217(5 \%)$

Scheme 80. Synthesis of compounds 215-217

In 1995 by de March, Font and coworkers described a formal total synthesis of (Z)-4-bromo-5(bromomethylene)-3-butyl-2(5H)-furanone (196) via a route involving the use of 4-bromo-3-butyl-5-methyl2(5H)-furanone (141) as a key intermediate (Scheme 81) [101]. Compound 141, which was prepared in $79 \%$ yield by bromination of methyl 2-butyl-2,3-pentadienoate (140) with 1.1 equiv of NBS in water at room temperature, was $t$ reacted with 1.5 equiv of NBS in $\mathrm{CCl}_{4}$ at $70-75^{\circ} \mathrm{C}$ for 130 $h$ in the presence of a catalytic amount of $\mathrm{NaHCO}_{3}$ providing a mixture of compounds 141, 218, 219 and 220 in $9 \%, 31 \%, 19 \%$ and $17 \%$ yield, respectively. Hydrolysis of this mixture followed by purification of the resulting crude products by flash chromatography allowed to isolate 4-bromo-3-butyl-5-hydroxy-5-methyl-2( $5 H$ )-furanone

(208) in 26\% yield. According to the literature [145] compound 208 is an advanced precursor to fimbrolide $\mathbf{1 9 6 .}$

In 2009, Janda and coworkers described a further synthesis of compound 196 that involved a new interesting protocol for the cyclization reaction of dibromocarboxylic acid 202 (Scheme 82) [146]. In fact, crude dibromocarboxylic acid 202, which was obtained by reacting ketoacid 201 with 2.2 equiv of bromine on a $2: 1$ mixture of $\mathrm{AcOH}$ and $\mathrm{CHCl}_{3}$, was reacted with fluorosulfonic acid in $\mathrm{CH}_{2} \mathrm{Cl}_{2}$ at $0{ }^{\circ} \mathrm{C}$ for $1 \mathrm{~h}$ and then at 50 ${ }^{\circ} \mathrm{C}$ for $2 \mathrm{~h}$ providing 196 in $33 \%$ yield based on 201. Notably, this cyclization protocol allowed to overcome the many problems related to the execution of the cyclization reaction making use of sulfuric acid at $110-120{ }^{\circ} \mathrm{C}$, i.e. low yields due to both polymerization and decomposition and possible explosion of the reaction content when the reaction is carried out upon scale-up [146].

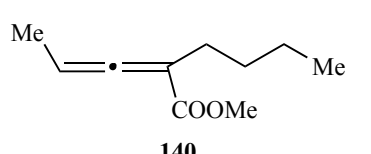

140

NBS (1.1 equiv)

$\mathrm{H}_{2} \mathrm{O}, 25^{\circ} \mathrm{C}, 16 \mathrm{~h}$

$(79 \%)$<smiles>CCCC1=C(Br)C(C)OC1=O</smiles>

141

NBS (1.5 equiv.)

$\mathrm{CCl}_{4}, 70-75^{\circ} \mathrm{C}$

$\mathrm{NaHCO}_{3}$ (cat), $130 \mathrm{~h}$
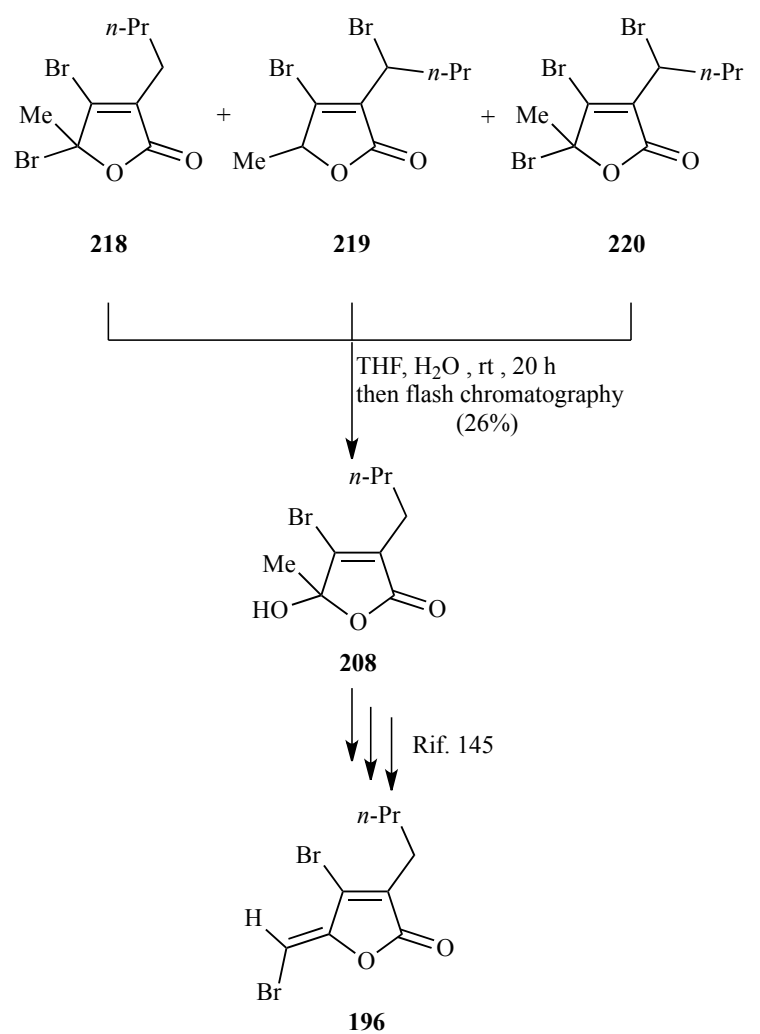

Scheme 81. Formal total synthesis of fimbrolide 196 
<smiles>CCCCC(C(=O)O)C(Br)C(=O)CBr</smiles><smiles>CCCCC1=C(Br)C(=CBr)OC1=O</smiles>

196

(33\% yield based on $\mathbf{2 0 1}$ )

Scheme 82. Synthesis of natural fimbrolide 196 via $\mathrm{FSO}_{3} \mathrm{H}$-mediated cyclization of crude compound $\mathbf{2 0 2}$

With regard to the bioactivity of $2(5 H)$-furanone derivatives featuring one bromine atom on the heterocyclic ring and mononobrominated substituents, it should be noted that since the late 1990s several studies have been conducted on the biological properties of (Z)-4-bromo-5(bromomethylene)-3-butyl-2(5H)-furanone (196). In 1998, Kjelleberg and coworkers, in the context of an investigation on the role of putative extracellular signal molecules in the regulation of the carbon starvation response of marine Vibrio sp. strain S14, discovered that compound 196 inhibits the synthesis of proteins specifically induced upon carbon starvation [147].

In 2000, Givskov and coworkers found that $\mathbf{1 9 6}$ inhibits the swarmimg motility of the Gram-negative bacterium Serratia liquefaciens MG1 and demonstrated that this natural compound controls transcription of the QS regulated gene $s w r A$ in competition with the cognate signal molecule $N$-butanoyl- $L$-homoserine lactone (197a, BHL) (Figure 15) [148].<smiles>CCCC(=O)NC1CCOC1=O</smiles>

Figure 15. Structure of $N$-butanoyl- $L$-homoserine lactone (BHL)

In 2001, Wood and coworkers found that 196 inhibits swarming motility of the Gram-negative bacterium Escherichia coli at $13 \mu \mathrm{g} / \mathrm{cm}^{2}$, but does not inhibit its growth rate at $13-52 \mu \mathrm{g} / \mathrm{cm}^{2}$ or from 20 to $100 \mu \mathrm{g} / \mathrm{mL}$ [149]. In addition, they demonstrated that $\mathbf{1 9 6}$ is capable to inhibit the biofilm formation of $E$. coli decreasing the thickness of the biofilm by $55 \%$ at $60 \mu \mathrm{g} / \mathrm{mL}$ and descreasing the percentage of live cells by $87 \%$.

In 2002, the same research group reported that $\mathbf{1 9 6}$ inhibits both the growth of the Gram-positive nonpathogenic bacterium Bacillus subtilis and its swarming motility in a concentration dependent way.[150] This research group also found that $\mathbf{1 9 6}$ is able to inhibit the biofilm formation of $B$. subtilis at $40 \mu \mathrm{g} / \mathrm{mL}$ decreasing the biofilm formation by $25 \%$ and reducing the percentage of live cells by $63 \%$ [150]. These results were of significant interest since biofilm formation of $B$. subtilis, which is apparently dependent on LuxS- ( $S$-ribosylhomocysteine lyase)-based QS by autoinducer 2 (AI-2), represents a continuous hygienic problem in the dairy industry and can lead to serious economic losses [151].

In 2004, in order to discover the mechanism of inhibition of the growth, swarming and biofilm formation in Gram-positive bacteria, Wood and coworkers investigated the gene expression profiles of $B$. subtilis grown with and without $5 \mu \mathrm{g} / \mathrm{mL}$ of compound 196 and found that this sublethal concentration led to the induction of specific genes involved in stress responses, fatty acid biosynthesis, lichenan degradation, transport and metabolism [152]

In the same year, Ren and Wood demonstrated that $\mathbf{1 9 6}$ is able to inhibit the mild steel corrosion induced by the Gram-positive sulphate-reducing bacterium Desulfotomaculum orientis [153]. In particular, they found that 20 and $40 \mu \mathrm{g} / \mathrm{mL}$ of 196 inhibited $58 \%$ and $96 \%$ of the D. orientis growth, respectively [153].

In 1998, Stintzi and coworkers showed that the siderophore synthesis in Pseudomonas aeruginosa may be regulated by QS [154] and, in 2005, Wood and coworkers evidenced the link between QS and siderophore synthesis of the Gram-negative pathogenic bacterium Pseudomonas putida F1 demonstrating that the QS disrupter 196 was able to inhibit the siderophore produced by this bacterium in a concentration dependent way, with $57 \%$ synthesis repressed by $100 \mu \mathrm{g} / \mathrm{mL}$ of 196 [155]. In contrast, 100 $\mu \mathrm{g} / \mathrm{mL}$ of 196 were found to stimulate siderophore biosynthesis in the opportunistic human pathogen Pseudomonas aeruginosa PA01 about 3.5 fold [155,156].

Again in 2005, Jones and coworkers ascertained that compound 196 is able to reduce the growth of the Grampositive bacterium Bacillus anthracis Sterne strain (the etiologic agent of anthrax) in a dose dependent manner [157]. In addition, Zang and coworkers reported that $\mathbf{1 9 6}$ covalently modifies and inactivates in a concentration dependent manner LuxS, the enzyme that produces autoinducer-2 (AI-2) [158], a signaling molecule that mediates inter-species QS among many bacteria [159]. 
In 2010, in the course of an investigation on the activity of brominated furanones on biofilm formation by Salmonella typhimurium ATCC 14028, De Keersmaecker and coworkers found that $\mathbf{1 9 6}$ is more active than the corresponding 3-alkyl-4-bromo-5-(dibromomethylene)2(5H)-furanone 211 (Figure 16),[109] a natural product isolated fron D. pulchra [139-141] and D. elegans [142].<smiles>CCCCC1=C(Br)C(=C(Br)Br)OC1=O</smiles>

Figure 16. Structure of the natural compound 211

Still in 2010, Ren and coworkers demonstrated the antifungal activity of naturally-occurring 196 on the Grampositive bacterium Candida albicans, a causal agent of opportunistic oral and genital infections in humans, and found that $3 \mu \mathrm{g} / \mathrm{mL}$ of this furanone upregulates 32 genes of the pathogen with functions of stress response, NAPDH dehydrogenation and small molecule transport and represses 21 genes involved in cell-wall maintainance [160].

The year before, Landmann and coworkers had found that $\mathbf{1 9 6}$ is able to enhance the biofilm formation of Staphylococcus epidermis strain 1457, S. epidermis strain 047 and $S$. aureus at concentrations between 1.25 and 20 $\mu \mathrm{M}$, which are 10 to $20 \%$ of the minimum inhibitory concentration (MIC) and correlate with an increase of polysaccharide intracellular adhesion, the major staphylococcal biofilms [161]. Notably, free, but not surface bound compound $\mathbf{1 9 6}$ was found to be toxic for staphylococci and eukaryotic cells to a similar extent, thus excluding a therapeutic application of this compound [161].

(Z)-3-(1-Acetoxybutyl)-4-bromo5-(bromomethylene) 2(5H)-furanone (221) (Figure 17) in another naturally occurring fimbrolide, isolated from D. pulchra [139-141] and D. elegans [142] that has been the subject of total synthesis.<smiles>CCCC(OC)C1=C(Br)/C(=C\Br)OC1=O</smiles>

221

Figure 17. Structure of (Z)-3-(1-acetoxybutyl)-4bromo-5-(bromomethylene)-2(5H)-furanone (221)

In 1993, Jefford briefly described a synthesis of $\mathbf{2 2 1}$ involving the use of 3-bromo-4-(1-hydroxybutyl)-2- methylfuran (138) (Scheme 83) [99], a compound available from 5-methylfurfural (132) according to the reaction sequence outlined in Scheme 49 [98]. Acetylation of $\mathbf{1 3 8}$ followed by double hydroxylation of the resulting acetate 222 gave 3-(1-acetoxybutyl)-4-bromo-5-hydroxy-5methyl-2(5H)-furanone 223 in high yield.
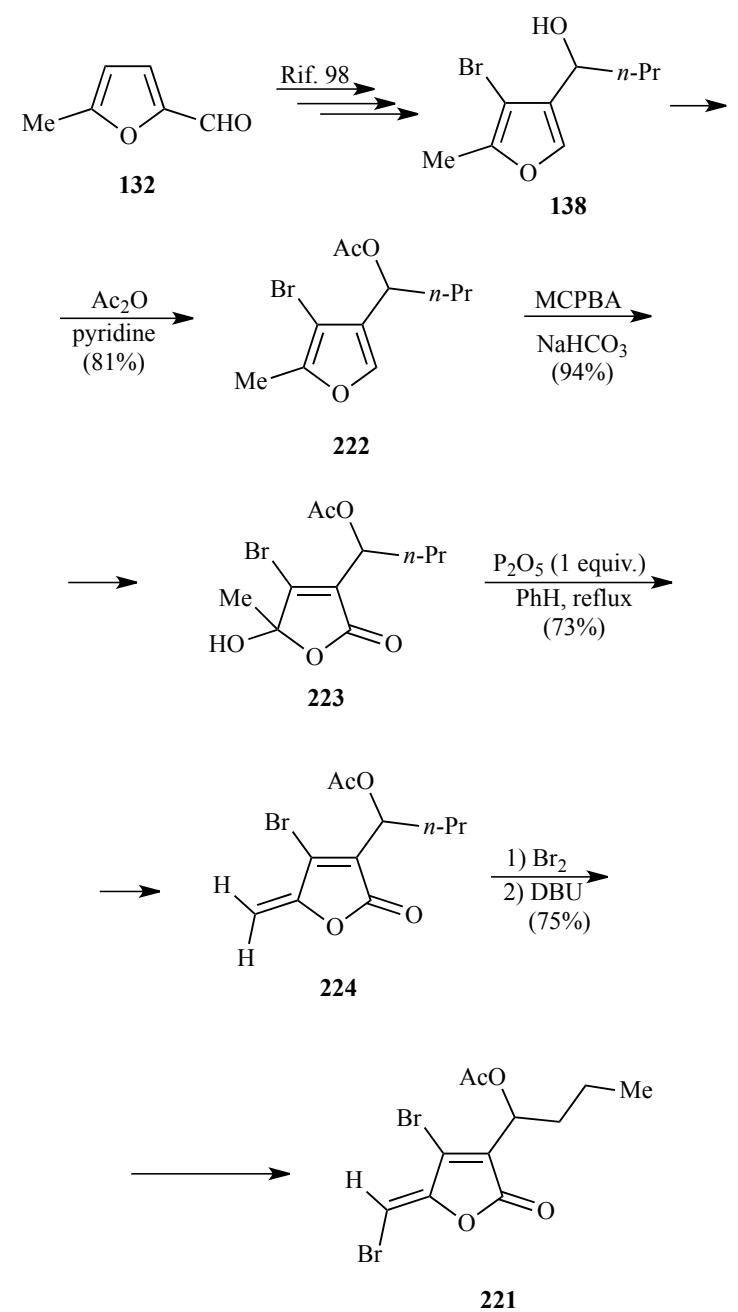

Scheme 83. Stereoselective synthesis of (Z)-3-(1acetoxybutyl)-4-bromo-5-(bromomethylene)-2(5H)furanone (221)

The reaction of 223 with 1.0 equiv of $\mathrm{P}_{2} \mathrm{O}_{5}$ in benzene under reflux led to 3-(1-acetoxybutyl)-4-bromo-5methylene-2(5H)-furanone (224) in $73 \%$ yield. Finally, addition of bromine to this compound, followed by DBUmediated deydrobromination of the resulting adduct provided compound $\mathbf{2 2 1}$ in $\mathbf{7 5 \%}$ yield (Scheme 83) [99].

In 1995, de March, Font and coworkers described another synthesis of fimbrolide 221 (Scheme 84) [101]. 


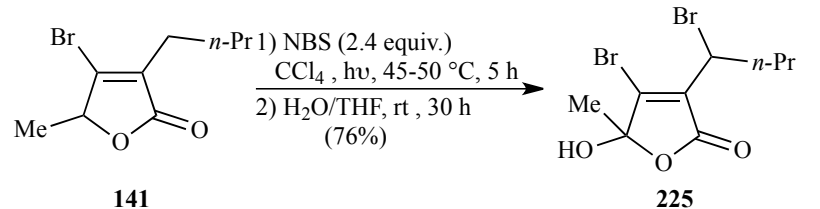

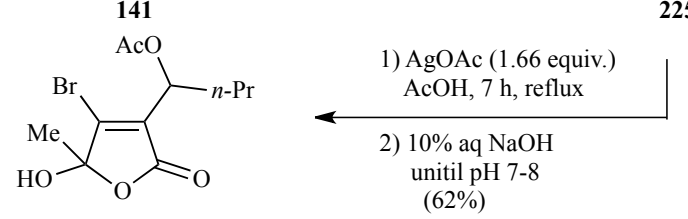

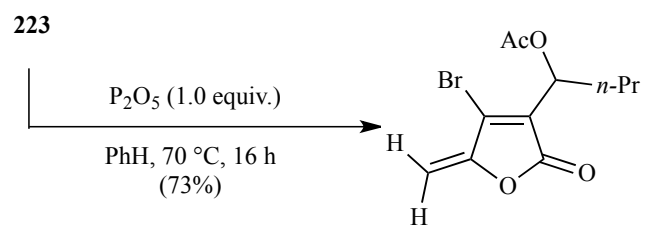

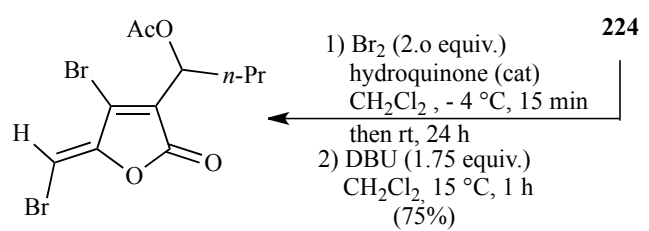

221

Scheme 84. Synthesis of fimbrolide 221 starting from furanone 141

The developed route involved the reaction of 4-bromo3-butyl-5-methyl-2(5H)-furanone (141) [101] with 2.4 equiv of NBS in $\mathrm{CCl}_{4}$ at $40-45^{\circ} \mathrm{C}$ under irradiation for $5 \mathrm{~h}$ and hydrolysis of the resulting product providing compound $\mathbf{2 2 5}$ in $76 \%$ yield. Treatment of $\mathbf{2 2 5}$ with 1.46 equiv of $\mathrm{AgOAc}$ in glacial acetic acid followed by addition of $10 \%$ aqueous $\mathrm{NaOH}$ until $\mathrm{pH} 7-8$ produced compound 223 in $62 \%$ yield, which was reacted with $\mathrm{P}_{2} \mathrm{O}_{5}$ in benzene at $70{ }^{\circ} \mathrm{C}$ producing 224 in $73 \%$ yield. Finally, addition of 2.0 equiv of bromine to a $\mathrm{CH}_{2} \mathrm{Cl}_{2}$ solution of 24 at $-4{ }^{\circ} \mathrm{C}$ in the presence of a catalytic amount of hydroquinone and the subsequent dehydrobromination of the resulting adduct with 1.75 equiv of $\mathrm{DBU}$ in $\mathrm{CH}_{2} \mathrm{Cl}_{2}$ at $-15{ }^{\circ} \mathrm{C}$ gave compound 221 in $75 \%$ yield [101].

As regards the synthesis of naturally-occurring 2(5H)furanone derivatives with one bromine atom on the heterocyclic ring and monobrominated substituents, it is worth noting that, in 2001, in connection with a project directed towards the synthesis of natural products and their analogues with potential cytotoxic activity against human tumor cell lines, our research group developed an efficient procedure for the synthesis of rubrolide N, a metabolite isolated from the marine ascidian Synoicum blochmanni to which the structure 226 (Figure 18) had been assigned by Salvá and coworkers [49].<smiles>O=C1O/C(=C\c2ccc(O)c(Br)c2)C(c2ccc(O)c(Cl)c2)=C1Br</smiles>

Figure 18. Proposed structure for rubrolide N

The synthesis of compound $\mathbf{2 2 5}$ was carried out by using the reaction sequence outlined in Scheme 85 [74].
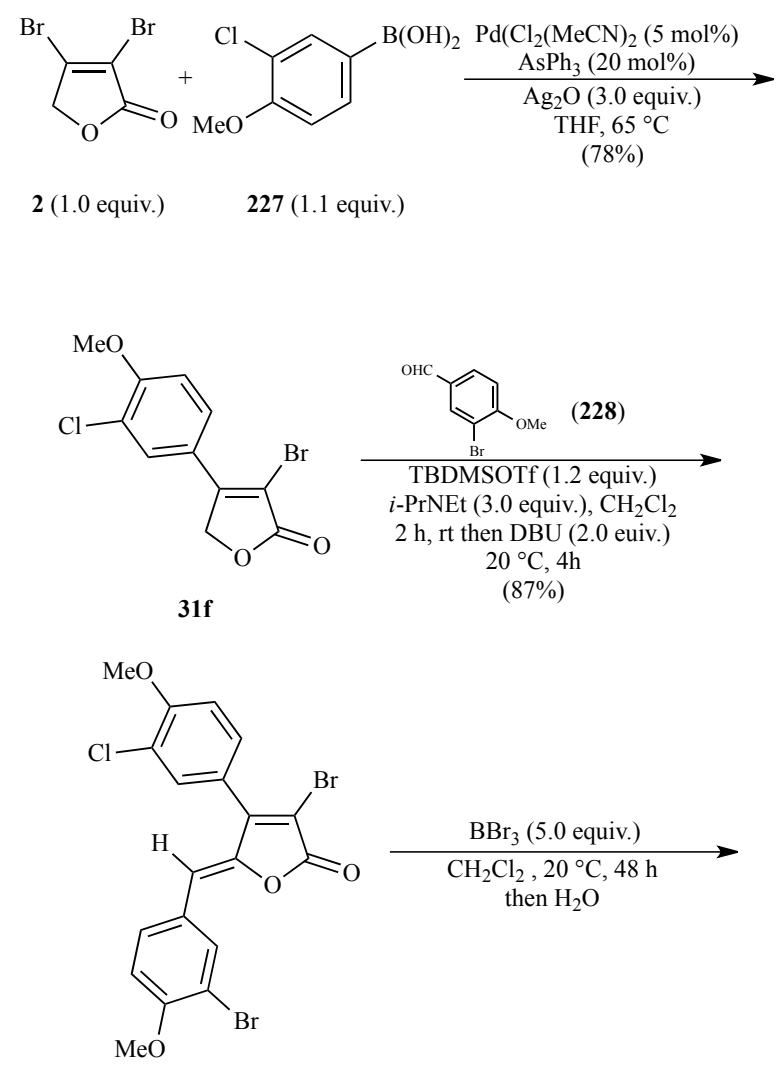

229

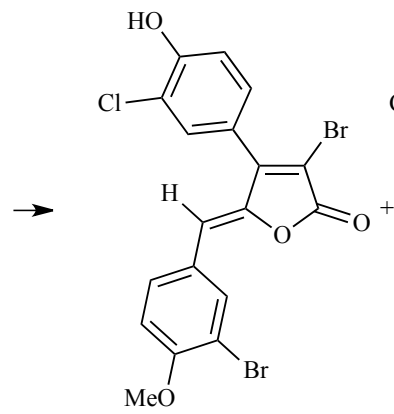

230 (51\%)<smiles>O=C1OC(=Cc2ccc(O)c(Br)c2)C(c2ccc(O)c(Cl)c2)=C1Br</smiles>

$226(47 \%)$ 
Scheme 85. Stereoselective synthesis of compound $\mathbf{2 2 5}$

3,4-Dibromo-2(5H)-furanone (2) was submitted to a Suzuki-Miyaura reaction with 1.1 equiv of arylboronic acid 227 in THF at $65{ }^{\circ} \mathrm{C}$ in the presence of 3.0 equiv of $\mathrm{Ag}_{2} \mathrm{O}$, $0.5 \mathrm{~mol}_{0} \mathrm{PdCl}_{2}(\mathrm{MeCN})_{2}$ and $20 \mathrm{~mol} \% \mathrm{AsPh}_{3}$ providing 4aryl-3-bromo-2(5H)-furanone $\mathbf{3 1 f}$ in $78 \%$ yield. $\mathrm{A} \mathrm{CH}_{2} \mathrm{Cl}_{2}$ solution of $\mathbf{3 1 f}$ was then sequentially treated with 1.2 equiv of TBDMSOTf, 3.0 equiv of $i$ - $\operatorname{Pr}_{2} \mathrm{NEt}$ and 1.0 equiv of 3 bromo-4-methoxybenzaldehyde (228) at room temperature for $2 \mathrm{~h}$ and the resulting mixture was reacted with 2.0 equiv of DBU at $20{ }^{\circ} \mathrm{C}$ for $4 \mathrm{~h}$ affording selectively compound 229 in $87 \%$ yield. Finally, the reaction of $\mathbf{2 2 9}$ with 5.0 equiv of $\mathrm{BBr}_{3}$ in $\mathrm{CH}_{2} \mathrm{Cl}_{2}$ at $20{ }^{\circ} \mathrm{C}$ for $48 \mathrm{~h}$ followed by hydrolysis led to a mixture of (Z)-3-bromo-4(3-chloro-4-hydroxyphenyl)-5-[1-(1-bromo-4-

methoxyphenyl)methylene]-2(5H)-furanone (230) and $(Z)$ 3-bromo-4-(3-chloro-4-hydroxyphenyl)-5-[1-(3-bromo-4hydroxyphenyl)methylene]-2(5H)-furanone (226) from which compounds $\mathbf{2 3 0}$ and $\mathbf{2 2 6}$ were isolated in 51\% and $47 \%$ yield, respectively [74]. However, several NMR parameters of compound $\mathbf{2 2 6}$ did not match with those reported for the natural product with the structure of rubrolide $\mathrm{N}$ [49].

Many other syntheses of unnatural 2(5H)-furanone derivatives bearing one bromine atom on the heterocyclic ring and monobrominated substituents have been reported in the literature.

In 1997, as part of a study of the mutagenicity of halogen-substituted furanones, LaLonde and coworkers synthesized 3-bromo-4-(bromomethyl)-2( $5 H)$-furanone (233), 3,5-dibromo-4-(bromomethyl)-2(5H)-furanone (234) and 3-bromo-4-(bromomethyl)-5-hydroxy-2(5H)furanone (235) using 4-(bromomethyl)-2(5H)-furanone (231) or 4-(hydroxymethyl)-2(5H)-furanone (232) as the starting material (Scheme 86) [162]. Addition of 4.6 equiv of bromine to a $\mathrm{CH}_{2} \mathrm{Cl}_{2}$ solution of $\mathbf{2 3 1}$ followed by treatment with 0.92 equiv of $\mathrm{Et}_{3} \mathrm{~N}$ provided compound $\mathbf{2 3 3}$ in only $12 \%$ yield. Nevertheless, compound 233 was obtained in $27 \%$ yield by the reaction of $\mathbf{2 3 2}$ with 3.3 equiv of bromine at room temperature for $8 \mathrm{~d}$ followed by $\mathrm{Et}_{3} \mathrm{~N}$ mediated dehydrobromination. The subsequent reaction of 233 with 1.0 equiv of NBS in $\mathrm{CCl}_{4}$ under irradiation with an incandescent lamp gave compound 234 in $98 \%$ yield and $94 \%$ GC purity. Finally, treatment of $\mathbf{2 3 4}$ with 1.5 equiv of $\mathrm{AgOAc}$ in $10 \%$ aqueous acetone for $4 \mathrm{~d}$ at room temperature gave 235 in $47 \%$ yield [162].

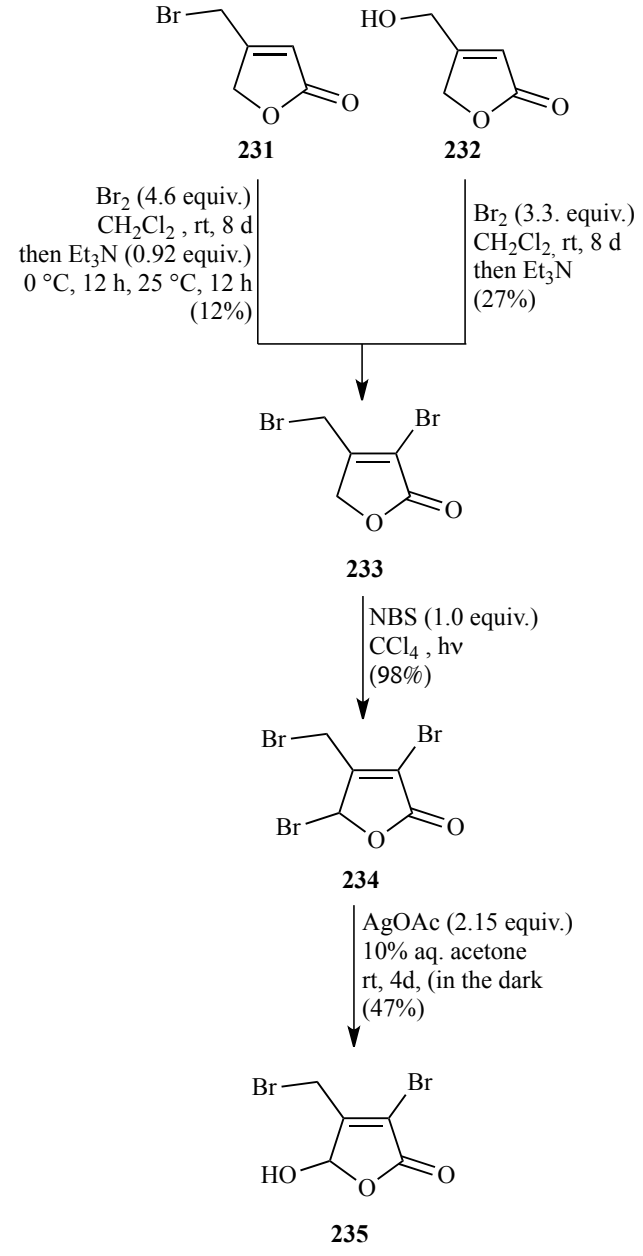

Scheme 86. Synthesis of compounds 233, 234 and 235

LaLonde and coworkers also evaluated the mutagenicity potency of compounds $\mathbf{2 3 3}$ and $\mathbf{2 3 5}$ in the Ames Salmonella typhimurium (TA100) assay and found that the mutagenicity value of $\mathbf{2 3 5}$ was 51.0 fold higher than that of 233, but considerbly smaller than that observed for the $\mathrm{H}-$ by-OH replacement for the dichloride pair $\mathbf{2 3 6}$ and $\mathbf{2 3 7}$ (Figure 19) [162]. In fact, 237 had a mutagenicity value of 145 fold higher than that of 236 [162].

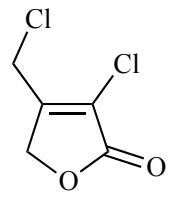

236<smiles>O=C1OC(O)C(CCl)=C1Cl</smiles>

237
Figure 19. Structures of compounds 236 and 237

In 2008, Benneche and coworkers carried out the synthesis of stereoisomeric mixtures of 3-bromo-5(bromomethylene)-2(5H)-furanone $\mathbf{2 3 9}$ by using three different protocols (Scheme 87) [163]. The first protocol 
(Method A) involved the cleavage of the tertbutyoxycarbonyl group of the $\alpha, \beta$-unsaturated ester 238 by treatment with trifluoroacetic acid (TFA) and addition of bromine to the resulting compound, followed by reaction with $\mathrm{Et}_{3} \mathrm{~N}$ in DMF at room temperature. This one-pot protocol provided a $11: 89$ mixture of $(E)$ - and $(Z)-\mathbf{2 3 9}$ in $56 \%$ yield, from which $(Z)-239$ was isolated in $50 \%$ yield. The second protocol (Method B) consisted of treatment of a $\mathrm{CCl}_{4}$ solution of $\mathbf{2 3 8}$ with bromine, addition of TFA to the resulting product, stirring the mixture at room temperature for $2 \mathrm{~d}$, and evaporation of the solvent followed by addition of DMF and $\mathrm{Et}_{3} \mathrm{~N}$ at $0{ }^{\circ} \mathrm{C}$. In this way a $60: 40$ mixture of $(E)$ - and (Z)-239 was obtained in 10\% yield. In the third protocol (Method $C$ ) compound $\mathbf{2 3 8}$ was reacted with TFA in $\mathrm{CH}_{2} \mathrm{Cl}_{2}$ at room temperature, the reaction mixture was evaporated and treated with bis(2,4,6trimethylpyridino)bromine(I) hexafluorophosphate in $\mathrm{CH}_{2} \mathrm{Cl}_{2}$ at $0{ }^{\circ} \mathrm{C}$ and after $2 \mathrm{~h}$ reacted with $1 \mathrm{M} \mathrm{HCl}$. This protocol allowed to obtain a mixture of $(E)$ - and $(Z)-239$ in a 2 : 98 ratio, respectively, from which compound (Z)-239 was isolated in $48 \%$ yield [163].

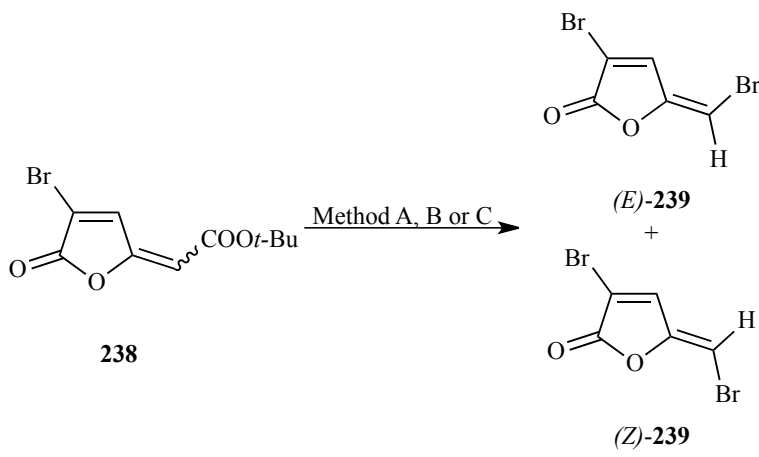

Method $A$ : 1) TFA, $\mathrm{CH}_{2} \mathrm{Cl}_{2}, 2 \mathrm{~h} ; 2$ ) $\mathrm{Br}_{2}$ (4.0 equiv.), $\mathrm{CDCl}_{3}$ rt, 2 - $3 \mathrm{~d} ; 3) \mathrm{Et}_{3} \mathrm{~N}$ (1.08 equiv.)

Method B : 1) $\mathrm{Br}_{2}$ (1.1.equiv.), $\mathrm{CCl}_{4}, \mathrm{rt}, 2 \mathrm{~h}$; 2) TFA, $\mathrm{CH}_{2} \mathrm{Cl}_{2}$ rt, $2 \mathrm{~h} ; 3) \mathrm{Et}_{3} \mathrm{~N}$ (1.08 equiv.), DMF, rt, $2 \mathrm{~h}$

Method $C$ : 1) TFA, $\left.\mathrm{CH}_{2} \mathrm{Cl}_{2}, \mathrm{rt}, 2 \mathrm{~h} ; 2\right) \mathrm{Br}^{+}(\mathrm{CoCl})_{2} \mathrm{PF}_{6}^{-}$(1.5 equiv.), $\left.\mathrm{CH}_{2} \mathrm{Cl}_{2}, 2 \mathrm{~h} ; 3\right) 1 \mathrm{M} \mathrm{HCl}$

\begin{tabular}{cccc}
\hline Method & $(E) /(Z)-\mathbf{2 3 9}$ & total yield $\%$ & yiled $\%$ of $(Z)-\mathbf{2 3 9}$ \\
\hline A & $11: 89$ & 56 & 50 \\
B & $60: 40$ & 10 & 4 \\
C & $2: 98$ & 49 & 48 \\
\hline
\end{tabular}

Scheme 87. Synthesis of compounds (E)- and (Z)-239

Notably, (Z)-239, which was a valuable intermediate to lissoclinolide (240), a metabolite of the tunicate Lissoclinum patella [164], at $60 \mu \mathrm{M}$ was found to reduce significantly bioluminescence in the Gram-negative, bioluminescent, marine bacterium Vibrio harveyi BB170 compared to control without furanone [40]. About this result, it must be pointed out that the use of the bioluminescence reduction bioassay of Vibrio harveyi constitutes a direct method of detecting potentially biohazardous materials in water [165].<smiles>O=C1OC(=CC=CCO)C=C1C=CCO</smiles>

Figure 20. Structure of lissoclinolide (240)

In 2012, Benneche and coworkers reported that a mixture of $(E)$ - and $(Z)$-239 in a $10: 90$ ratio, respectively, was obtained in $40 \%$ yield by reacting 4-bromo-5methoxyfurfural (241) with 1.3 equiv of oxalyl bromide (110) in $\mathrm{CH}_{2} \mathrm{Cl}_{2}$ at $0{ }^{\circ} \mathrm{C}$ and heating the resulting reaction mixture at room temperature for $45 \mathrm{~min}$ (Scheme 88) [166].<smiles>COc1oc(C=O)cc1Br</smiles><smiles>O=C(Br)C(=O)Br</smiles>

110 (1.13 equiv.)

Scheme 88. Synthesis of $(E) /(Z)-239$ from 4-bromo-5methoxyfurfural (241)

As mentioned in Section 2.2, in 2004, Brückner and coworkers synthesized (Z)-4-bromo-5-(bromomethylene)$2(5 H)$-furanone $(\mathbf{1 4 5})(\mathrm{C}-30)$ in $41 \%$ yield by the reaction of 3,5-dibromolevulinic acid (144) with concd. sulfuric acid at room temperature for $20 \mathrm{~min}$ and then at $85^{\circ} \mathrm{C}$ for $0.5 \mathrm{~h}$ (Scheme 51) [102]. In the same year, Johansen and coworkers prepared (Z)-4-bromo-5-(bromomethylene)$2(5 H)-\left[2-{ }^{14} \mathrm{C}\right]$ furanone $(\mathbf{2 4 7})$ in five steps in $7.7 \%$ overall yield starting from bromo $\left[1-{ }^{14} \mathrm{C}\right]$ acetic acid (242) (Scheme 89) [167]. Microwave-accelerated condensation of ethyl bromo[ $\left[1-{ }^{14} \mathrm{C}\right]$ acetate $(\mathbf{2 4 3})$ with ethyl acetoacetate (198) and acidic hydrolysis of the resulting diester $\mathbf{2 4 4}$ followed by decarboxylation by microwave heating gave [1$\left.{ }^{14} \mathrm{C}\right]$ levulinic acid $\mathbf{2 4 5}$. Finally, the bromination reaction of 245 followed by sulfuric acid-mediated cyclization of the resulting dibrominated carboxylic acid $\mathbf{2 4 6}$ gave the targeted labelled 2(5H)-furanone 247 with a radiochemical purity higher than $97 \%$ and specific activity of 57 $\mathrm{mCi} / \mathrm{mmol}[167]$. 

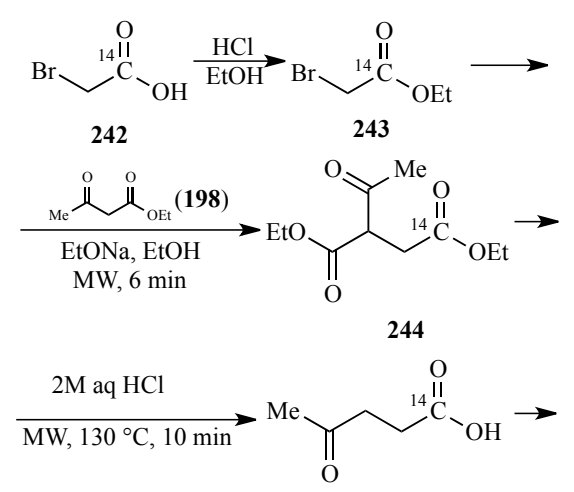

245
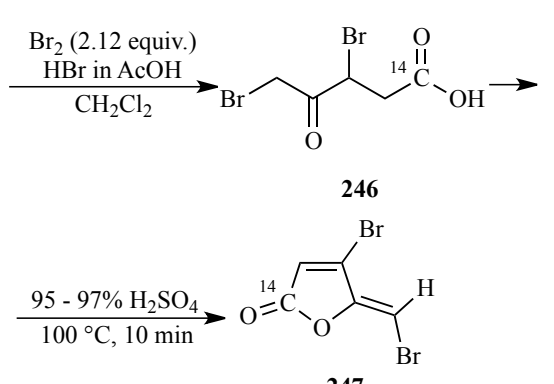

247

Scheme 89. Synthesis of (Z)-4-bromo-5(bromomethylene)-2(5H)-[2- $\left.{ }^{14} \mathrm{C}\right]$ furanone $(\mathbf{2 4 7})$

In the last two decades, the bioactivity of (Z)-4-bromo5-(bromomethylene)-2(5H)-furanone (145) (C-30) has been the subject of several studies.

In 2004, $\mathrm{Wu}$ and coworkers demonstrated that this compound interfers with the action of $\mathrm{N}$-acyl homoserine lactones by inhibiting in vivo gene expression regulated by QS systems in Pseudomonas aeruginosa [21]. Furthermore, these authors showed that 145 also exerts favourable therapeutic effects in $P$. aeruginosa lung infection in mice [21] reducing the inflammation in vivo. In fact, $\quad N$-(3-oxododecanoyl)homoserine lactone, an important QS signal produced by $P$. aeruginosa, has been shown to have inflammatory effects [168].

In 2010. Roques and coworkers found that $\mathbf{1 4 5}$ is able to inhibit the growth and to restrict the number of adherent $P$. aeruginosa cells when added from the early stages of biofilm formation (i.e. adhesion and microcolony formation) in a dose dependent way [169].

In 2013, Defoirdt and coworkers demonstrated that the QS-disrupter 145 increases the survival of giant freshwater prawn Macrobrachium rosenbergii larvae when challenged to pathogenic Vibrio harveyi [170].

In 2015, Chan and coworkers carried out a study in which they fabricated on microarc-oxidized titanium a new antibacterial agent, compound $\mathbf{1 4 5}$ loaded poly $(L$-lactic acid) nanoparticles, and found that this antibacterial coating produced a unique inhibition zone against Stapylococcus aureus throughout a 60-day period, which is long enough to prevent the infection around implants in the early and intermediates stages [171].

In the same year, Quan and coworkers incorporated for the first time compound $\mathbf{1 4 5}$ into Nafion polymer and investigated the antimicrobial and anti-biofilm properties of the resulting composite film against mixed culture and three strans of P. aeruginosa, E. coli and Bacillus subtilis [172]. The results indicated that $\mathbf{1 4 5}$ or Nafion alone could inhibit all colonization and that when 145 was incorporated into the Nafion polymer, synergetic anti-biofilm effects were obtained [172].

Finally, still in 2015, Li and coworkers obtained results showing that 145 efficiently inhibits biofilm formation by Acidithiobacillus ferroxidans (a Gram-negative bacterium commonly found in acid mine drainage and deep caves) and that the inhibition of biofilm formation is correlated with a decrease in the production of extracellular polymeric substance [173]. Notably, the reduction in the production of extracellular substances led to reduced biofilms on pentlandite, the most common terrestrial nickel sulfide, and to reduced pentantlandite attachment [173].

In 2008 Ren, Luk and coworkers synthesized $(E)-4-$ bromo-5-(bromomethylene)-3-methyl-2 $(5 H)$-furanone (249) (BF-8) by bromination of 2-methyllevulinic acid (248), followed by oxidative ring closure under acidic conditions of the resulting dibrominated compound (Scheme 90) [174].

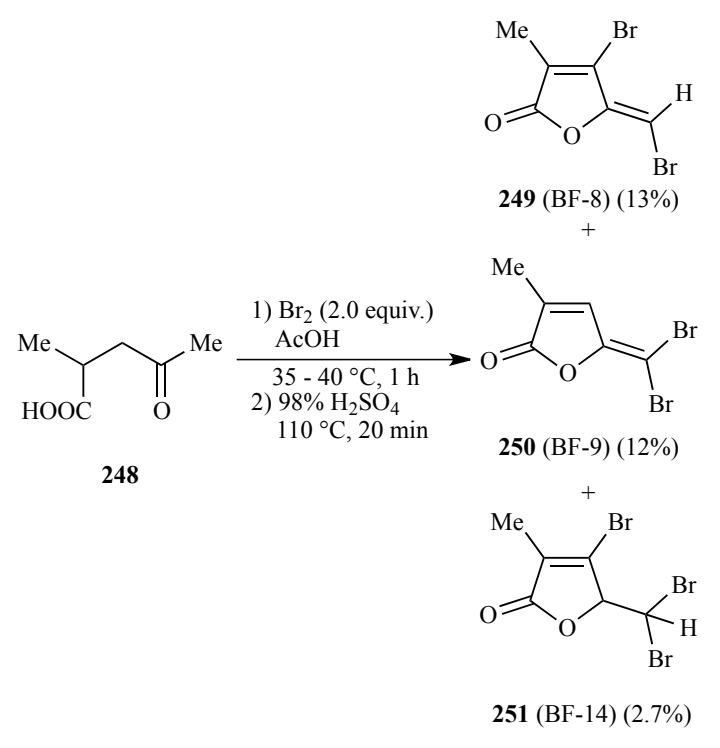

Scheme 90. Synthesis of compounds 249-251

Notably, the reaction also produced 4-bromo-5(dibromomethylene)-3-methyl-2(5H)-furanone (250) (BF9) and 4-bromo-5-(dibromomethyl)-3-methyl-2(5H)- 
furanone (251) (BF-14) in $12 \%$ and $2.7 \%$ yield, respectively (Scheme 90) [174]. Interestingly, compound 249 was found to exhibit significant inhibition activity for E. coli biofilm formation [174].

In 2012, Ren and coworkers showed that $\mathbf{2 4 9}$ could also act synergistically with antibiotics to enhance killing of $P$. aeruginosa PAO1 persister cells (a subpopulation of bacterial cells that are dormant and tolerant to antibiotics) and could also restore the susceptibility of isolated persister cells to antibiotics [175].

One year later, Ren and coworkers demonstrated that the QS inhibitor 249 (BF-8) could reduce persistance during the growth of $E$. coli and revert the antibiotic tolerance of its persister cells [176]. Again in 2013, the same research group characterized the effects of compound 249 on the mucoid strain P. aeruginosa PDO300 and found that this brominated furanone is able to reduce persistence during the growth of $P$. aeruginosa PDO300 and effectively to kill the persister cells isolated from this strain [177]. Furthermore, compound 249 was capable to inhibit biofilm formation of PDO300 and to reduce associated persistence [177].

In 2009, Kumar and coworkers carried out the synthesis of 4-substituted (Z)-3-bromo-5-(bromomethylene)-2(5H)furanones $\mathbf{2 5 7} \mathbf{a}-\mathbf{h}$ by using the reaction sequence outlined in Scheme 91 [178]. Thus, addition of bromine to carboxylic acids $\mathbf{2 5 2}$, followed by cyclodehydration of the resulting dibromolevulinic acids 253 with $\mathrm{P}_{2} \mathrm{O}_{5}$ in $\mathrm{CH}_{2} \mathrm{Cl}_{2}$ gave compounds $\mathbf{2 5 4}$ in moderate to good yields. Dehydrobromination of these substances with DBU in $\mathrm{CH}_{2} \mathrm{Cl}_{2}$ yielded 5-methylene-2(5H)-furanones 253, which were reacted with bromine to give selectively compounds 256. Finally, dehydrobromination of these substances with $i$ - $\mathrm{Pr}_{2} \mathrm{NEt}$ in $\mathrm{CH}_{2} \mathrm{Cl}_{2}$ provided compounds $\mathbf{2 5 7}$ stereoselectively and in moderate to satisfactory yields. For instance, the reaction of $\mathbf{2 5 6 \mathbf { d }}(\mathrm{R}=n$-Hex) with 3.4 equiv of $i$ - $\mathrm{Pr}_{2} \mathrm{NEt}$ in $\mathrm{CH}_{2} \mathrm{Cl}_{2}$ at room temperature for $72 \mathrm{~h}$ produced compound 257d in 55\% yield [178]. However, the stereoisomeric purities of compounds 257 were not reported [178].
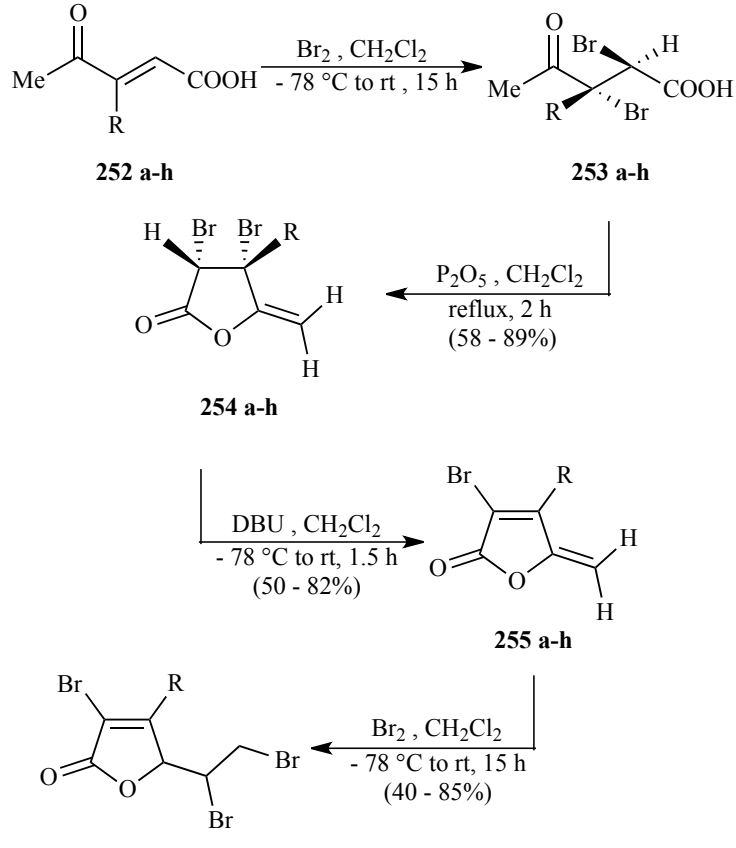

256 a-h

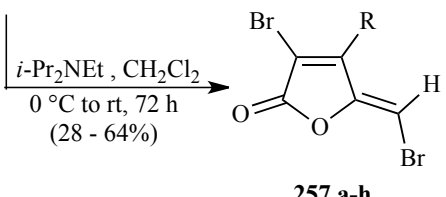

\begin{tabular}{cc}
\hline 257 & $\mathrm{R}$ \\
\hline 257a & $\mathrm{Me}$ \\
257b & $n$-Pr \\
257c & $n-\mathrm{Bu}$ \\
$\mathbf{2 5 7 d}$ & $n-\mathrm{Hex}$ \\
$\mathbf{2 5 7 e}$ & $n-\mathrm{Hept}$ \\
$\mathbf{2 5 7 f}$ & $n-\mathrm{Dec}$ \\
$\mathbf{2 5 7 g}$ & $\mathrm{Ph}$ \\
$\mathbf{2 5 7 h}$ & $\mathrm{Bn}$ \\
\hline
\end{tabular}

Scheme 91. Synthesis of 4-substituted (Z)-3-bromo-5(bromomethylene)-2(5H)-furanones $\mathbf{2 5 7} \mathbf{a}-\mathbf{h}$

In 2015, Barbosa and coworkers synthesized (Z)-5-(1arylmethylene)-3-bromo-4-(5-bromo-2-methoxyphenyl)$2(5 H)$-furanones $91 \mathbf{k}-\mathbf{0}$ via a route (Scheme 92) in which the first step was the $\mathrm{PdCl}_{2}(\mathrm{MeCN})_{2} / \mathrm{AsPh}_{3}$-catalyzed regioselective $\mathrm{C}-4$ arylation reaction of 3,4-dibromo2(5H)-furanone (2) with 5-bromo-2-methoxyphenylboronic acid (258) in THF at $65{ }^{\circ} \mathrm{C}$ in the presence of $\mathrm{Ag}_{2} \mathrm{O}$ [76]. The resulting 3-bromo-4-(5-bromo-2-methoxyphenyl)$2(5 H)$-furanone $\mathbf{( 3 1 g )}$, which was obtained in $29 \%$ yield, was reacted with 2.2 equiv of TBDMSOTf, 3.0 equiv of $i$ $\mathrm{Pr}_{2} \mathrm{NEt}$ and 1.1 equiv of the required aryl aldehydes in $\mathrm{CH}_{2} \mathrm{Cl}_{2}$ at room temperature and the crude reaction products were treated with 2.2 equiv of DBU under reflux providing compounds $91 \mathbf{k}-\mathbf{0}$ in $40-63 \%$ yield based on 31g (Scheme 92) [76]. The lowest yield was obtained by 
using an aryl aldehyde with the strong electronwithdrawing $\mathrm{CF}_{3}$ substituent [76].

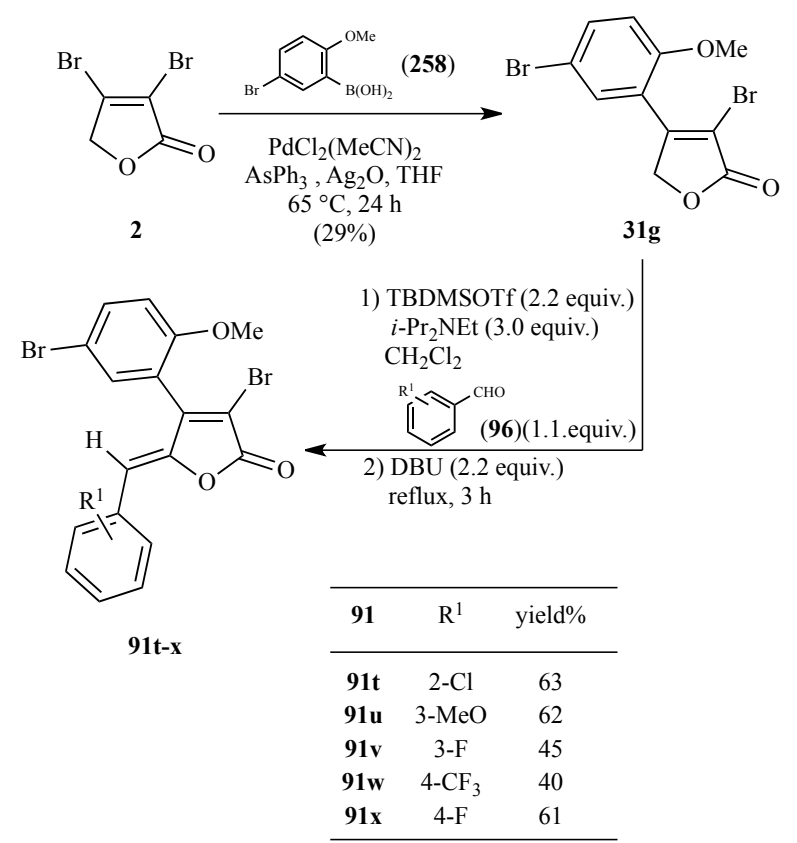

Scheme 92. Synthesis of (Z)-5-(1-arylmethylene)-3bromo-4-(5-bromo-2-methoxyphenyl)-2(5H)-furanones 91t-x

In 2016, Barbosa and coworkers found that compound 91n caused a decrease in HL-60 cell viability followed by an increase in the apoptoric and necrotic cells in a concentration dependent manner [179].

The year before, Bouillon, Médebielle and coworkers prepared (Z)-3-bromo-5-(4-bromobenzylidene)-4methoxy-2(5H)-furanone (102h) in $73 \%$ yield by treatment of a $89: 11(Z) /(E)$ - mixture of 5-(4-bromobenzylidene)-4methoxy-2(5H)-furanone $(\mathbf{1 0 1 h})$ with 1.5 equiv of bromine and 1.2 equiv of pyridine in $\mathrm{CH}_{2} \mathrm{Cl}_{2}$ at room temperature (Scheme 93) [82].

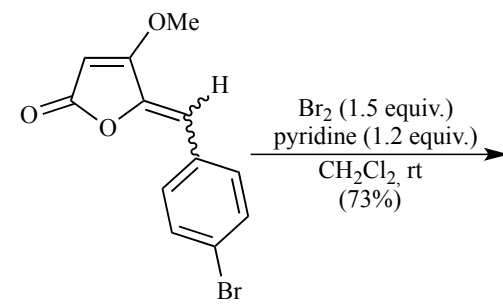

$101 \mathrm{~h}$

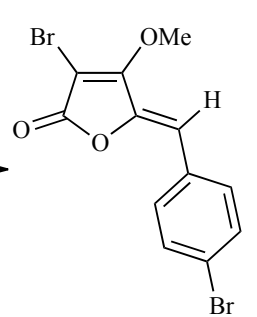

$102 h$
Scheme 93. Synthesis of (Z)-3-bromo-5-(4bromobenzylidene)-4-methoxy-2(5H)-furanone (102h)

The stereoisomeric mixture of compound $\mathbf{1 0 1 h}$ was in turn prepared in $44 \%$ yield from 4-methoxy-2(5H)- furanone (98a) according to the reaction sequence outilined in Scheme 35 [82].

In concluding this section, it deserves also to be mentioned that, in 2001, our research group synthesized (Z)-3-bromo-4-(3-chloro-4-methoxyphenyl)-5-[1-(3-

bromo-4-methoxyphenyl)methylene]-2(5H)-furanone (229) (Figure 18) in $87 \%$ yield by using the procedure developed to prepare compounds $\mathbf{8 9} \mathbf{a}$ and $\mathbf{8 9 b}$ (Scheme 32) [74]. Compound 229 was then $O$-demethylated by treatment with 5.0 equiv of $\mathrm{BBr}_{3}$ in $\mathrm{CH}_{2} \mathrm{Cl}_{2}$ at room temperature for $48 \mathrm{~h}$ providing the rubrolide analogue 226 (Figure 21)in $51 \%$ yield [74].<smiles>COc1ccc(C2=C(Br)C(=O)O/C2=C\c2ccc(OC)c(Br)c2)cc1Cl</smiles>

229<smiles>O=C1O/C(=C\c2ccc(O)c(Br)c2)C(c2ccc(O)c(Cl)c2)=C1Br</smiles>

226
Figure 21. Structures of compounds 229 and $\mathbf{2 2 6}$

Notably, compounds $\mathbf{2 2 9}$ and $\mathbf{2 2 6}$ proved to be highly cytotoxic for MCF-7, NCI-H460 and SF-268 cancer cell lines. In fact, their values for the growth reduction of any one of the cell lines were negative numbers, which indicated cell kill [74].

\section{SYNTHESIS AND BIOACTIVITY OF 2(5H)-} FURANONE DERIVATIVES FEATURING ONE BROMINE ATOM ON THE HETEROCYCLIC RING AND DIBROMINATED SUBSTITUENTS

In 1997, 3-bromo-4-(dibromomethyl)-2(5H)-furanone (261) was synthesized by LaLonde and coworkers starting from 4-acetoxymethyl-2(5H)-furanone $(\mathbf{2 5 9})$ via the route outlined in Scheme 94 [162]. In particular, the reaction of 259 with 3.1 equiv of bromine in $\mathrm{CH}_{2} \mathrm{Cl}_{2}$ for $10 \mathrm{~d}$, followed by treatment with 1.04 equiv of $\mathrm{Et}_{3} \mathrm{~N}$ gave compound 260 in $40 \%$ yield. Acidic hydrolysis of the ester group of $\mathbf{2 6 0}$ in methanol furnished compound $\mathbf{2 6 1}$ in $77 \%$ yield. The subsequent reaction of $\mathbf{2 6 1}$ with a mixture of 2.1 equiv of pyridinium chlorochromate (PCC) and 31.3 equiv of $\mathrm{NaCl}$ in $\mathrm{CH}_{2} \mathrm{Cl}_{2}$ gave 3-bromo-4-formyl-2(5H)-furanone (262) in $76 \%$ yield. Finally, treatment of this compound with the reagent prepared from equimolar amounts of bromine and triphenylphosphite led to the target compound $\mathbf{2 6 3}$ in 53\% yield (Scheme 94) [162]. It was then found that 263 was mutagenic in the Salmonella typhimurium 
(TA100-S9) assay with a mean mutagenicity value of 82.4 revertants/mmol [162].

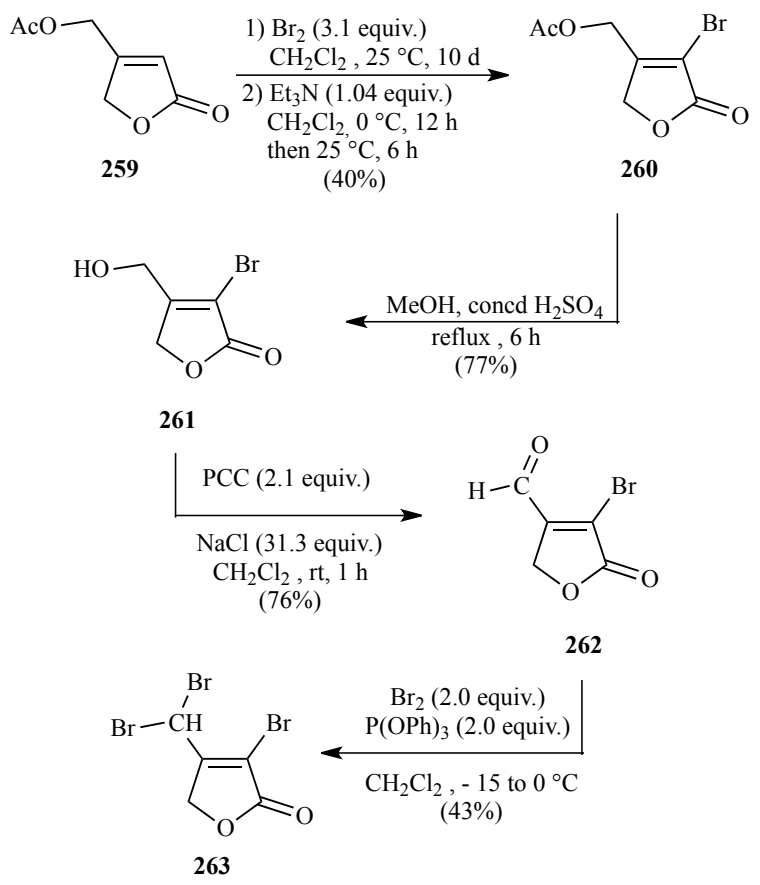

Scheme 94. Synthesis of 3-bromo-4-(dibromomethyl)2(5H)-furanone (263)

In 2000, 3-bromo-4-(dibromomethyl)-5-hydroxy-2(5H)furanone (264a) (Figure 22), which is the brominated analogue of the potent environmental mutagen 3-chloro-4(dichloromethyl)-5-hydroxy-2(5H)-furanone (264b) (MX) (Figure 22) [180-182], was synthesized by the reaction sequence illustrated in Scheme 95 [183].

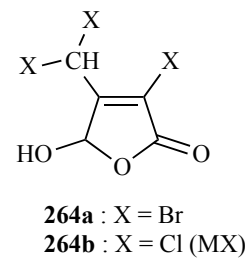

Figure 22. Structures of compounds 264a and 264b (MX)

The synthesis began with the addition of bromine to methyl 3-methyl-2-butenoate (265a) and the subsequent dehydrobromination with $\mathrm{Et}_{3} \mathrm{~N}$ of the resulting adduct, which led to compound 266 in $77 \%$ yield.

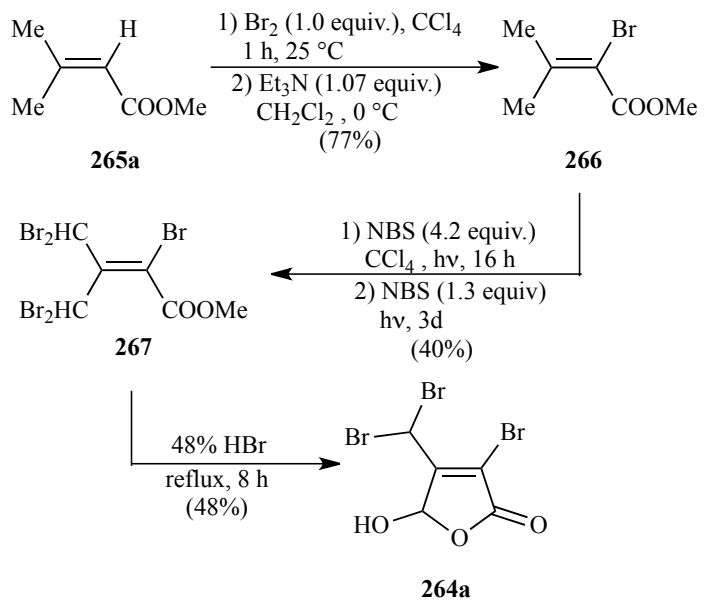

Scheme 95. Synthesis of 3-bromo-4-(dibromomethyl)5-hydroxy-2(5H)-furanone (264a)

At first, three bromine atoms were introduced by treatment of this compound with 4.2 equiv of NBS in $\mathrm{CCl}_{4}$ under irradiation for $6 \mathrm{~h}$ and. The subsequent introduction of the fourth bromine atom into the resulting product(s) was accomplished by treatment with 1.3 equiv of NBS in $\mathrm{CCl}_{4}$ under irradiation for $3 \mathrm{~d}$. In this way compound $\mathbf{2 6 7}$ was obtained in $40 \%$ yield. Finally, 267 was converted to 3-bromo-4-(dibromomethyl)-5-hydroxy-2(5H)-furanone (264a) in $48 \%$ yield by treatment with $48 \% \mathrm{HBr}$ under reflux for $8 \mathrm{~h}$ [183].

It is interesting to note that, previously, 264a had been found to be present in chlorinated drinking waters in concentrations comparable to that of 264b (MX) [184].

In 2008, Ren, Luk and coworkers reported that the reaction of 5-(dibromomethylene)-3-methyl-2 $(5 H)$ furanone (250) with 2.0 equiv of $\mathrm{NBS}$ in $\mathrm{CCl}_{4}$ under reflux for $12 \mathrm{~h}$, in the presence of 0.2 equiv of dibenzoyl peroxide, provided a mixture of 3-bromo-5(dibromomethylene)-2(5H)-furanone (268) (BF-11) and 3(dibromomethyl)-5-(dibromomethylene)-2 $(5 H)$-furanone

(269) (BF-10) (Scheme 96) [174]. Column chromatography of this mixture allowed to obtain pure compounds 268 and 269 in $50 \%$ and $13 \%$ yield, respectively [174]. Compound $\mathbf{2 5 0}$ was in turn obtained in $18 \%$ yield by bromination of 2 -methyllevulinic acid (248), followed by oxidative ring closure under acidic conditions of the resulting brominated derivative [174]. Data were also obtained suggesting that $\mathbf{2 6 8}$ is bactericidal to Escherichia coli [174]. 


$$
\text { (Pros }
$$

Scheme 96. Synthesis of compounds 268 and 269

One year earlier, Haval and Argade had described a synthesis of a mixture of naturally-occurring ( $Z$ )-4-bromo5-(dibromomethylene)-3-butyl-2(5H)-furanone (211) and (Z)-4-bromo-5-(bromomethylene)-3-butyl-2(5H)-furanone (196) via a multi-step reaction sequence in which $\mathrm{N}$-(4tolyl)maleimide (270) was used as the starting material (Scheme 97) [185]. Specifically, compound 270 was converted to 3-butylfuran-2,5-dione (271) in $61.5 \%$ yield through a five-step sequence. The reaction of 271 with 1.1 equiv of methylmagnesium iodide in $\mathrm{Et}_{2} \mathrm{O}$ at $-20{ }^{\circ} \mathrm{C}$ followed by hydrolysis gave 3-butyl-5-hydroxy-5-methyl2(5H)-furanone (272) and 4-butyl-5-hydroxy-5-methyl$2(5 H)$-furanone $(\mathbf{2 7 3})$ in $62 \%$ and $9 \%$ yield, respectively. The subsequent treatment of compound 272 with $\mathrm{P}_{2} \mathrm{O}_{5}$ in benzene under reflux provided the expected butenolide 274. Finally, addition of 2.2 equiv of bromine to 274 followed by reaction of the resulting adduct with 2.2 equiv of $\mathrm{Et}_{3} \mathrm{~N}$ in $\mathrm{CHCl}_{3}$ gave a mixture of fimbrolides 211 and 196, which were separated by HPLC using a known procedure [140]. Compounds 211 and 196 were so obtained in $18 \%$ and $37 \%$ yield, respectively (Scheme 97) [185]

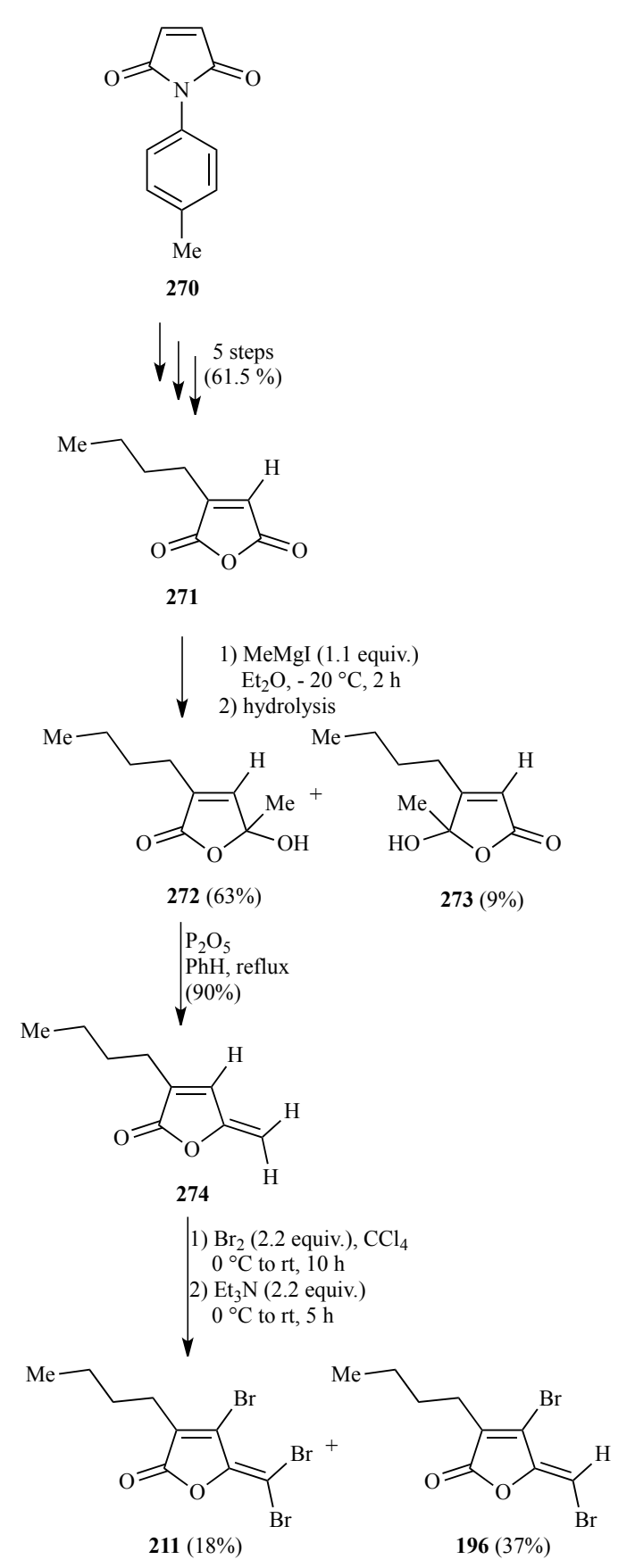

Scheme 97. Synthesis of naturally occurring fimbrolides 211 and 196

It should be noted that Givskov and coworkers had previously found that compound $\mathbf{2 1 1}$, similarly to $\mathbf{1 9 6}$, is able to inhibit swarming motility of the Gram-negative bacterium Serratia liquefaciens MG1 and to control transcription of the QS regulated gene swrA in competition with the cognate signal molecule BHL [148].

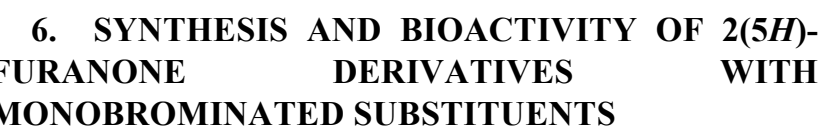


In 1966, 4-bromomethyl-3-ethoxycarbonyl-2(5H)furanone (277) was synthesized in two steps starting from diethyl isopropylidenemalonate (275) (Scheme 98) [186].

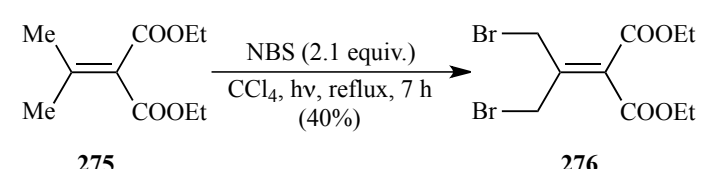<smiles>CCOC(=O)C1=C(CBr)COC1=O</smiles>

277

Scheme 98. Synthesis of 4-bromomethyl-3ethoxycarbonyl-2(5H)-furanone (277)

The reaction of $\mathbf{2 7 5}$ with 2.1 equiv of $\mathrm{NBS}$ in $\mathrm{CCl}_{4}$ under reflux and irradiation with a $200 \mathrm{~W}$ lamp produced compound 276 in $40 \%$ yield. The subsequent reaction of 276 with trifluoroacetic acid at $80{ }^{\circ} \mathrm{C}$ for $48 \mathrm{~h}$ yielded the required compound 277 in $53 \%$ yield [186].

In 1976, Martin and coworkers carried out the synthesis of 4-bromomethyl-2(5H)-furanone (231) in $28.8 \%$ overall yield by treatment of ethyl 3-methyl-2-butenoate (265b) with 2.17 equiv of NBS in $\mathrm{CCl}_{4}$ under reflux and irradiation with a $100 \mathrm{~W}$ lamp and cyclization of the resulting compound 278 by reaction with $48 \% \mathrm{HBr}$ under reflux (Scheme 99) [113].

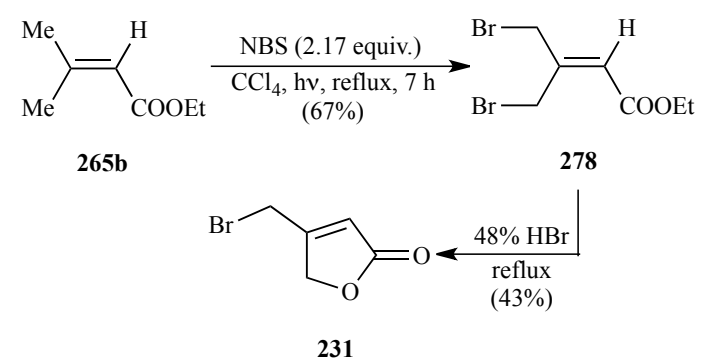

Scheme 99. Synthesis of 4-bromomethyl-2(5H)furanone (231)

In 1983, Kotsuki, Monden and Ochi described an efficient synthesis of (Z)-3-(1-acetoxybutyl)-5(bromomethylene)-2(5H)-furanone (285) in which methyl levulinate dimethyl ketal (279) was used as the starting material (Scheme 100) [187].
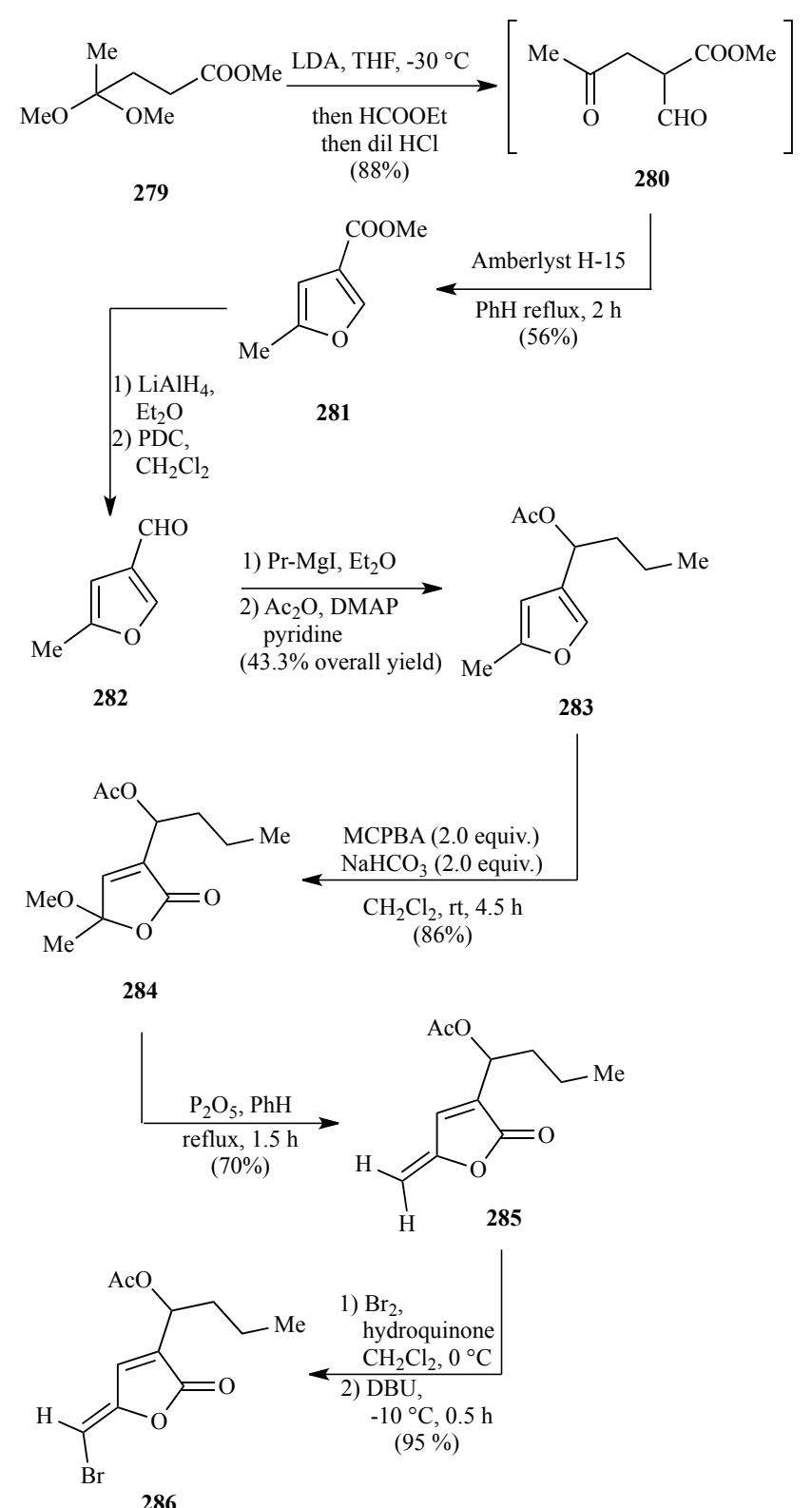

Scheme 100. Synthesis of (Z)-3-(1-acetoxybutyl)-5(bromomethylene)-2(5H)-furanone (286)

Formylation of 279 and treatment of the resulting crude product 280 with Amberlyst H-15 produced methyl 5methyl-3-furoate (281) in a satisfactory yield. Reduction of 281 with $\mathrm{LiAlH}_{4}$ in $\mathrm{Et}_{2} \mathrm{O}$ followed by oxidation of the resulting alcohol with pyridinium dichromate (PDC) in $\mathrm{CH}_{2} \mathrm{Cl}_{2}$ gave 5-methyl-3-formylfuran (282), which was then converted to compound $\mathbf{2 8 3}$ in $\mathbf{4 3 . 3 \%}$ overall yield by treatment with propylmagmesium iodide and acetylation of the resulting alcohol. Oxidation of $\mathbf{2 8 3}$ with 2.0 equiv of $m$-chloroperbenzoic acid in $\mathrm{CH}_{2} \mathrm{Cl}_{2}$ at room temperature in the presence of 2.0 equiv of $\mathrm{NaHCO}_{3}$ led to a diastereomeric mixture of 2(5H)-furanone $\mathbf{2 8 4}$ in $86 \%$ yield. This compound was dehydrated with $\mathrm{P}_{2} \mathrm{O}_{5}$ in benzene under reflux providing 5-methylene-2(5H)- 
furanone $\mathbf{2 8 5}$ in $70 \%$ yield. Finally, addition of bromine to 285 in the presence of a catalytic amount of hydroquininone and the subsequent dehydrobromination of the resulting adduct by treatment with DBU at $-10{ }^{\circ} \mathrm{C}$ led to compound $\mathbf{2 8 6}$ in 95\% yield (Scheme 100) [187].

Four years later, Font and coworkers synthesized 3-(1bromobutyl)-2(5H)-furanone (292) from commercially available $\gamma$-butyrolactone (287) through a route in which 3 (1-hydroxybutyl)-2(5H)-furanone (291) was the unexpected direct precursor to 292 (Scheme 101) [188].
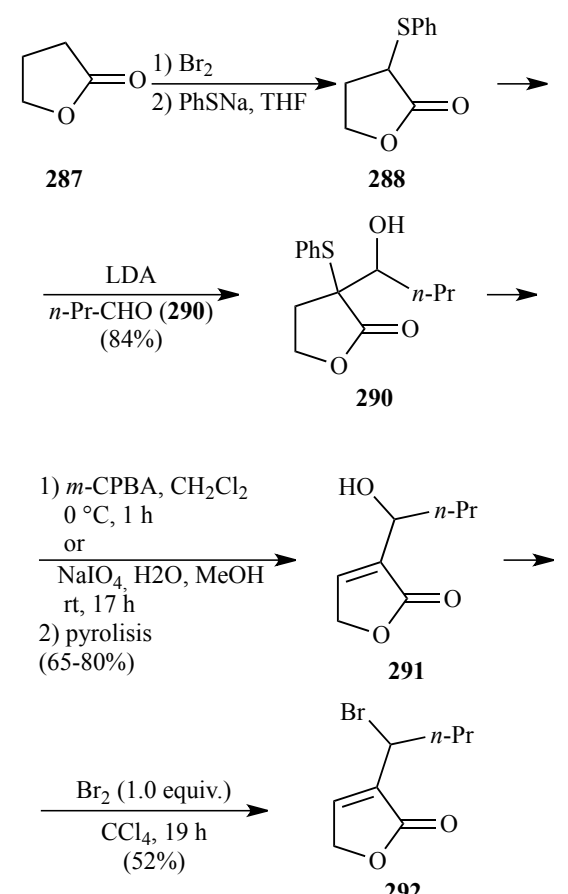

Scheme 101. Synthesis of 3-(1-bromobutyl)-2(5H)furanone (292)

Specifically, lactone $\mathbf{2 8 7}$ was converted to 3(phenylthio)-4,5-dihydrofuran-2(3H)-one (288) and the $\alpha$ carbanion of this compound was reacted with butanal (289) providing compound 290 as a $1: 1$ diastereomeric mixture in $84 \%$ yield. Oxidation of 290 with $m$-CPBA in $\mathrm{CH}_{2} \mathrm{Cl}_{2}$ at $0{ }^{\circ} \mathrm{C}$ for $1 \mathrm{~h}$ or with sodium periodate in a $1: 1$ mixture of water and methanol at room temperature for $17 \mathrm{~h}$, followed by pyrolysis of the resulting sulfoxide gave compound 291 in $65-80 \%$ yield. Finally, the substitution of the allylic hydroxyl group in $\mathbf{2 9 1}$ with bromine occurred unexpectedly under typical bromination conditions. In fact, treatment of 291 with 1.0 equiv of bromine in $\mathrm{CCl}_{4}$ gave bromide 292 in 52\% yield (Scheme 101) [188].

In 1995, Sánchez-Ferrando and coworkers reported a two-step synthesis of 5-(1-bromoethyl)-2(5H)-furanone (294) in which sorbic acid (18) was the starting material (Scheme 102) [36]. In particular, the reaction of 18 with
1.25 equiv of bromine in water at $85{ }^{\circ} \mathrm{C}$ for $1 \mathrm{~h}$ and then for $2 \mathrm{~h}$ at room temperature gave $(E)$-5-bromo-4-hydroxy2-hexenoic acid (293) in 35\% yield. The subsequent reaction of $\mathbf{2 9 3}$ in acidic water under UV irradiation provided compound 294 in 70\% yield (Scheme 102) [36].

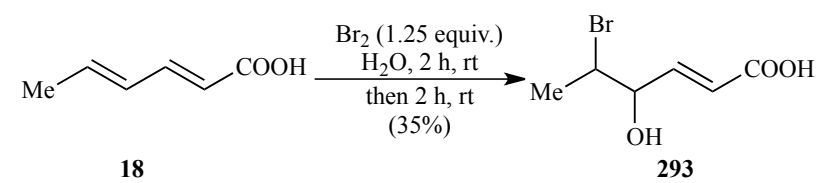<smiles>CC(Br)C1C=CC(=O)O1</smiles>

Scheme 102. Synthesis of 5-(1-bromoethyl)-2(5H)furanone (294)

In 2000, 4-(bromochloromethyl)-3-chloro-5-hydroxy2(5H)-furanone (297) (BMX-1) and 3-chloro-4(dibromomethyl)-5-hydroxy-2(5H)-furanone (298) (BMX2) were synthesized by Messeguer and coworkers from methyl-3-methyl-2-butenoate (265a) using the reaction sequence outlined in Scheme 103 [183, 189].

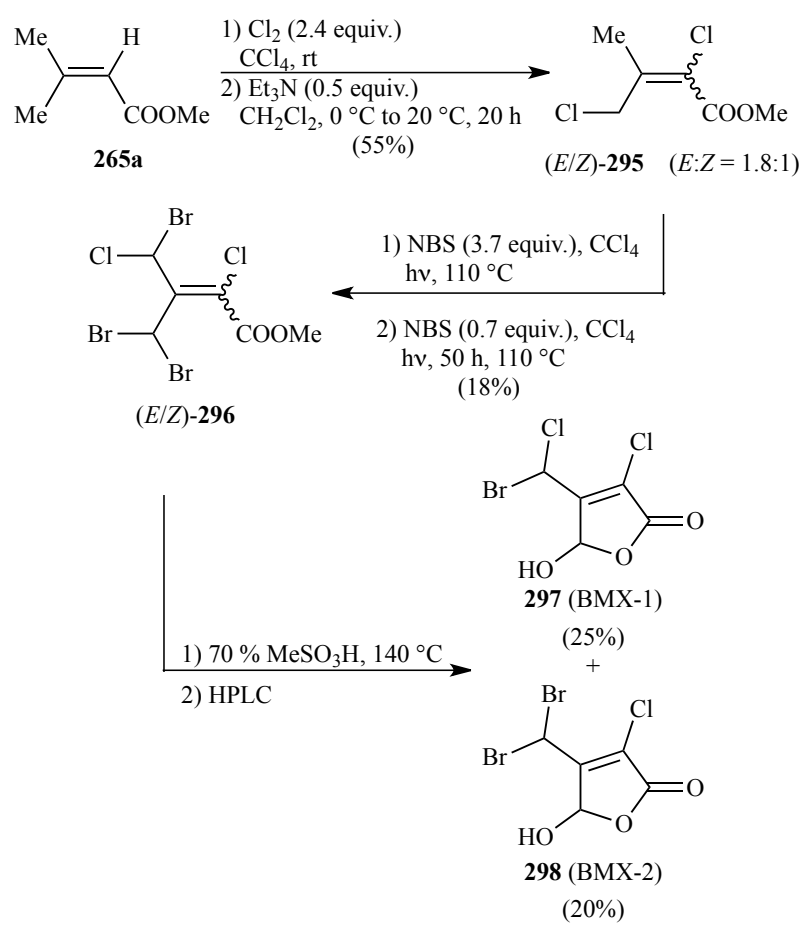

Scheme 103. Synthesis of compounds 297 (BMX-1) and $298(\mathrm{BMX}-2)$

Chlorination of $265 \mathrm{a}$ by treatment with 2.4 equiv of chlorine in $\mathrm{CCl}_{4}$ solution at room temperature, followed by dehydrochlorination with 0.5 equiv of $\mathrm{Et}_{3} \mathrm{~N}$ in $\mathrm{CH}_{2} \mathrm{Cl}_{2}$ led in $55 \%$ yield to a stereoisomeric mixture of 295 in which 
the $E$ - and $Z$-stereoisomers were in a $1.8: 1$ ratio. This mixture was subjected to allylic bromination with an excess of NBS in the presence of light at $110{ }^{\circ} \mathrm{C}$ producing a mixture of $(E)$ - and $(Z)-296$ in a $1: 1$ ratio and in only $18 \%$ yield. Finally, hydrolysis and subsequent cyclization of this mixture by treatment with $70 \%$ methanesulfonic acid at $140{ }^{\circ} \mathrm{C}$ gave a mixture of compounds 297 (BMX-1) and 298 (BMX-2) from which pure compounds 297 and 298 were isolated in $25 \%$ and $20 \%$ yield, respectively, via reversed phase HPLC $[183,189]$.

In 2003, Lumbard and coworkers described a simple synthesis of 297 (BMX-1), 298 (BMX-2) and 3-bromo-4(dibromomethyl)-5-hydroxy-2(5H)-furanone (299) (BMX3) from 3-chloro-4-(dichloromethyl)-5-hydroxy-2(5H)furanone (264b) (MX) (Scheme 104) [190].

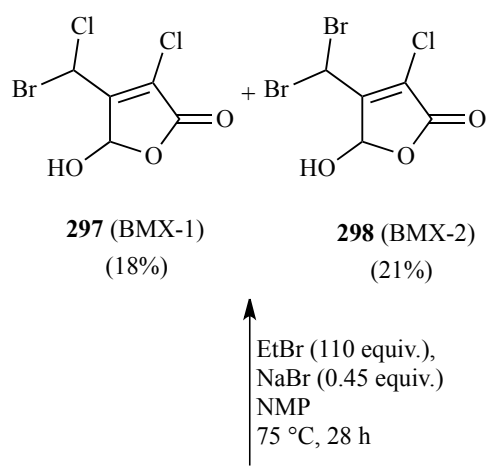<smiles>O=C1OC(O)C(C(Cl)Cl)=C1Cl</smiles>

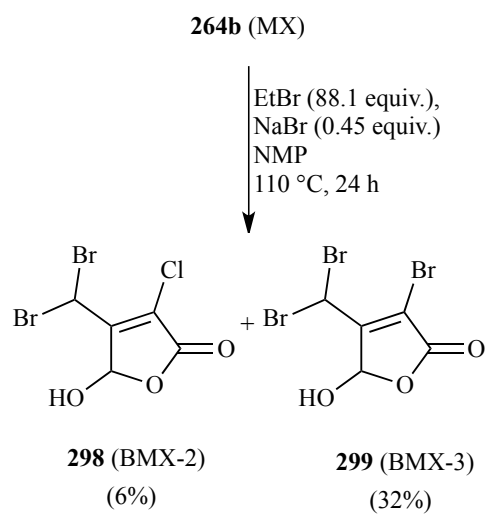

Scheme 104. Synthesis of compounds 297-299 from 264b (MX)

They reported that the reaction of $\mathrm{MX}$ with 110 equiv of ethyl bromide and 0.45 equiv of $\mathrm{NaBr}$ in dry 1-methyl-2pyrrolidinone at $75{ }^{\circ} \mathrm{C}$ for $28 \mathrm{~h}$ gave BMX-1 and BMX-2 in $18 \%$ and $21 \%$ yield, respectively. They also found that treatment of MX with 88.1 equiv of ethyl bromide and 2.0 equiv of $\mathrm{NaBr}$ in dry 1-methyl-2-pyrrolidinone at $100{ }^{\circ} \mathrm{C}$ for $24 \mathrm{~h}$ produced BMX-2 and BMX-3 in $6 \%$ and $32 \%$ yield, respectively (Scheme 104) [190].

In 2000, Messeguer and coworkers evaluated the mutagenic activity of compounds BMX-1, BMX-2 and BMX-3 by employing the Ames test with Salmonella typhimurium strain TA98 and TA100 and found that the mutagenic potencies in TA100 without S9 metabolic activation were $22.05 \pm 3.15$ revertants/ng for BMX-1 (297), $28.64 \pm 2.65$ revertants/ng for BMX-2 (298) and $37.29 \pm 5.73$ revertants/ng for BMX-3 (299) [189]. Notably, the mutagenic potencies proved to be six-to-nine fold lower in the TA98 strain without metabolic activation [189].

In 2002, our research group described the first synthesis of rubrolide $\quad \mathrm{M} \quad\{(Z)$-5-[1-(3-bromo-4hydroxyphenyl)methylene]-3-chloro-4-(4-hydroxyphenyl)2(5H)-furanone) (304) (Scheme 105) [123], a natural compound isolated from the ascidian Synoicum blochmanni [49].<smiles>COc1ccc(C2=C(Cl)C(=O)OC2)cc1</smiles><smiles>COc1ccc(C2=C(Cl)C(=O)O/C2=C\c2ccc(OC)c(Br)c2)cc1</smiles><smiles>COc1ccc(C2=C(Cl)C(=O)O/C2=C\c2ccc(OC)c(Br)c2)cc1</smiles>

Scheme 105. Regio- and stereoselective synthesis of rubrolide M (304) 
The stereo- and regioselective synthesis of $\mathbf{3 0 4}$ began with the Suzuki-Miyaura cross-coupling reaction of 3,4dichloro-2 $(5 H)$-furanone $\mathbf{( 3 0 0 )}$ with 1.1 equiv of arylboronic acid $\mathbf{3 0 1}$ in the presence of $\mathrm{KF}$ as the base, a $\mathrm{Pd}_{2}(\mathrm{dba})_{3} / \mathrm{P}(o-\mathrm{Tol})_{3}$ catalyst system and using toluene as solvent, which gave compound $\mathbf{3 0 2}$ in $61 \%$ yield. This $2(5 H)$-furanone derivative was then treated with 1.2 equiv of TBDMSOTf, 3.0 equiv of $i-\mathrm{Pr}_{2} \mathrm{NEt}$ and 1.0 equiv of 3 bromo-4-methoxybenzaldehyde $\mathbf{( 2 2 8 )}$ in $\mathrm{CH}_{2} \mathrm{Cl}_{2}$ at room temperature and the resulting crude aldol derivative was treated with 2.0 equiv of DBU at room temperature for $6 \mathrm{~h}$. Acidification of the resulting reaction mixture led to conpound 303 in $46 \%$ yield, which on treatment with 7.0 equiv of $\mathrm{BBr}_{3}$ in $\mathrm{CH}_{2} \mathrm{Cl}_{2}$ at room temperature, followed by hydrolysis provided rubrolide $\mathrm{M}$ (304) in 97\% yield [123].

In 2003, we evaluated the cytotoxic activity in vitro of rubrolide $\mathrm{M}$ against the NCI three-cell line panel consisting of MCF-7, SF-268 and NCI-H460 cancer cells and found that this compound was significantly cytotoxic against all three cell lines [191].

In 2004, Brückner and coworkers described low yielding stereoselective routes to $(Z)-5$-[trans-1-bromo-3phenyl-2-propenylidene]-2(5H)-furanone (306) and $(Z)-5$ (1-bromo-1-phenylmethylene)-2(5H)-furanone $\mathbf{( 3 0 8 )}$ in which of 3,5-dibromolevulinic acid (144) was the starting material (Scheme 106) [102].

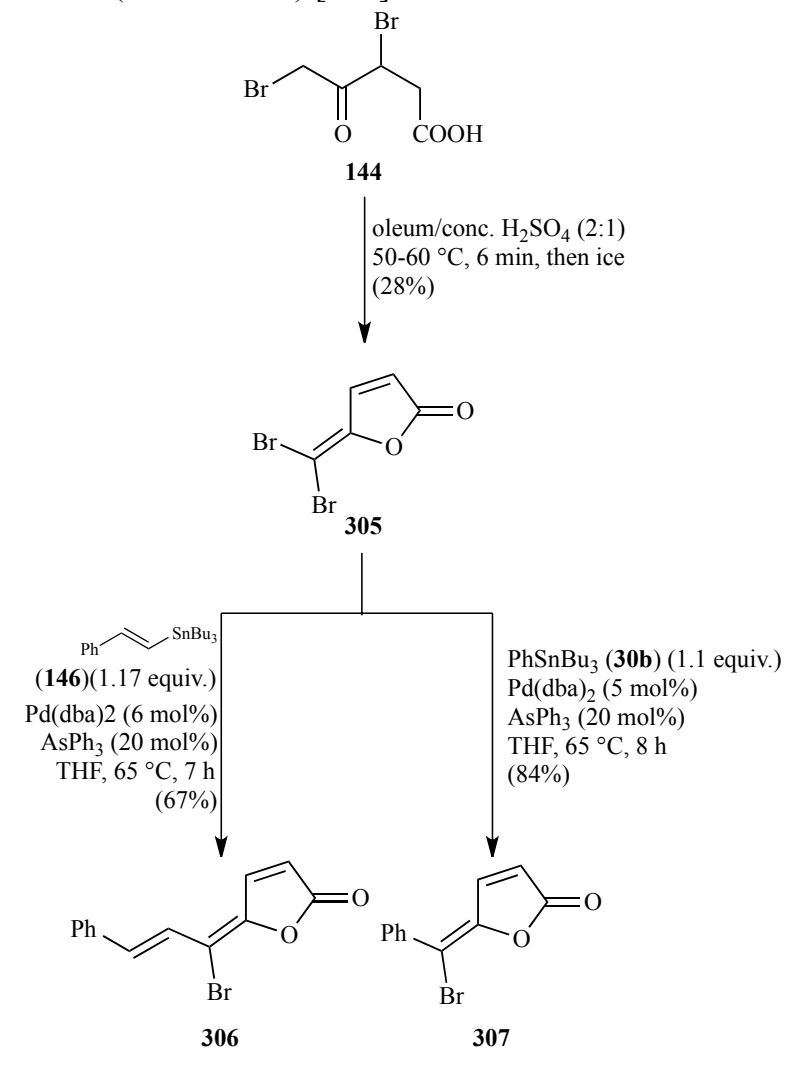

Scheme 106. Stereoselective synthesis of compounds 306 and 307
The syntheses began with the reaction of easily accessible compound $144[103,192]$ with a $2: 1$ mixture of oleum and concd. sulfuric acid at $50-60{ }^{\circ} \mathrm{C}$ for $6 \mathrm{~min}$, which led to 5(dibromomethylene)-2(5H)-furanone (305) in $28 \%$ yield. The subsequent $\mathrm{Pd}(\mathrm{dba})_{2} / \mathrm{AsPh}_{3}$-catalyzed Stille-type reaction of 305 with $(E)$-2-phenylethenyltributyltin (146) in $\mathrm{THF}$ at $65{ }^{\circ} \mathrm{C}$ produced stereoisomerically pure 306 in $67 \%$ yield. Furthermore, an analogous $\mathrm{Pd}(\mathrm{dba})_{2} / \mathrm{AsPh}_{3}-$ catalyzed cross-coupling reaction of $\mathbf{3 0 5}$ with phenyltributyltin (30b) provided compound $\mathbf{3 0 7}$ in $84 \%$ yield [102].

One year later, Brückner and coworkers synthesized (Z)-5-(bromomethylene)-2(5H)-furanone (308) in 51\% yield by stereoselective reduction of 5(dibromomethylene)-2(5H)-furanone (305) with 1.1 equiv of $\mathrm{Bu}_{3} \mathrm{SnH}$ in $\mathrm{THF}$ at $65{ }^{\circ} \mathrm{C}$ in the presence of $10 \mathrm{~mol} \%$ $\mathrm{Pd}\left(\mathrm{PPh}_{3}\right)_{4}($ Scheme 107) [192]. Compound 308 was in turn obtained in $55 \%$ yield by treatment of 3,5 dibromolevulinic acid (144) with 1.2 equiv of $\mathrm{P}_{4} \mathrm{O}_{10}$ in $\mathrm{CH}_{2} \mathrm{Cl}_{2}$ under reflux, followed by reaction with 1.03 equiv of $\mathrm{Et}_{3} \mathrm{~N}$ in $\mathrm{CH}_{2} \mathrm{Cl}_{2}$ at first at $0{ }^{\circ} \mathrm{C}$ and then under reflux for $1 \mathrm{~h}$ (Scheme 107) [192].<smiles>O=C1C=CC(=C(Br)Br)O1</smiles>

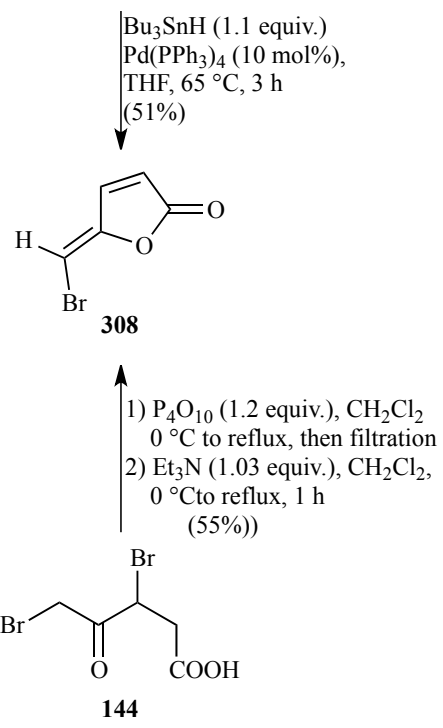

Scheme 107. Stereoselective synthesis of (Z)-5(bromomethylene)-2(5H)-furanone (307)

In 2006, Benneche and coworkers developed a synthesis of (Z)-5-(bromomethylene)-2(5H)-furanone (308) and its (E)-stereoisomer, 311 (Scheme 108) [193] starting from the $\alpha, \beta$-unsaturated ester 309 [194]. They reported that treatment of $\mathbf{3 0 9}$ with TFA in $\mathrm{CH}_{2} \mathrm{Cl}_{2}$ at room temperature for $2 \mathrm{~h}$ gave $(E)$-2-(5-oxofuran-2(5H)-ylidene)acetic acid 
(310) in quantitative yield. They then found that addition of 4.0 equiv of bromine to $\mathbf{3 1 0}$ in $\mathrm{CDCl}_{3}$ solution, followed by treatment of the resulting adduct with 1.08 equiv of $\mathrm{Et}_{3} \mathrm{~N}$ in a microwave oven for $1 \mathrm{mn}$ in the presence of DMF (Method $A$ ) gave 311 in 7\% yield together with $\mathbf{3 0 8}$ in $46 \%$ yield. On the other hand, the halodecarboxylation reaction of $\mathbf{3 1 0}$ with 1.07 equiv of $\operatorname{bis}(2,4,6-$ trimethylpyridino)bromine(I) hexafluorophosphate $\left[\mathrm{Br}^{+}\right.$ (coll) ${ }_{2} \mathrm{PF}_{6}^{-}$] [195] in $\mathrm{CH}_{2} \mathrm{Cl}_{2}$ at $0^{\circ} \mathrm{C}$ for $15 \mathrm{~min}$ and at room temperature for $2 \mathrm{~h}$ (Method $\mathrm{B}$ ) gave stereoisomerically pure 311 in 22\% yield (Scheme 108) [193].
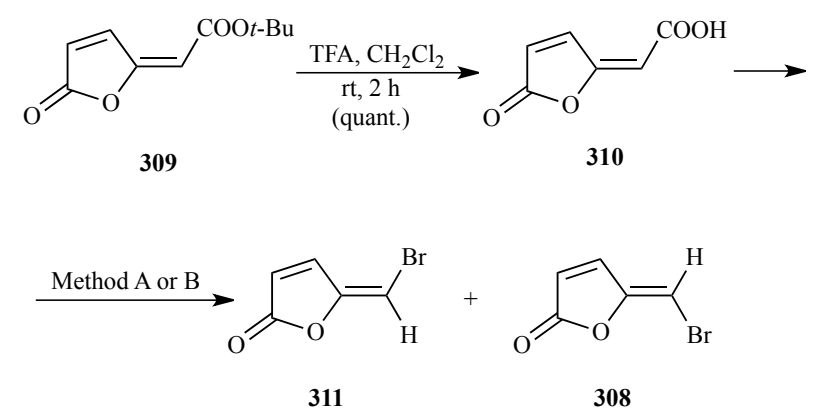

Method A: a) $\mathrm{Br}_{2}$ (4.0 equiv.), $\mathrm{CDCl}_{3}, \mathrm{rt}, 3 \mathrm{~h}$;

b) $\mathrm{Et}_{3} \mathrm{~N}$ (1.08 equiv.), DMF, MW, $1 \mathrm{~min}$

Method B: $\mathrm{Br}^{+}$(coll) ${ }_{2} \mathrm{PF}_{6}{ }^{-}\left(1.07\right.$ equiv.), $\mathrm{CH}_{2} \mathrm{Cl}_{2} \mathrm{cf}, 0{ }^{\circ} \mathrm{C}, 15 \mathrm{~min}, \mathrm{rt}, 2 \mathrm{~h}$

\begin{tabular}{ccc}
\hline Method & Yield (\%) & $\mathbf{3 1 1 / 3 0 8}$ \\
\hline A & 53 & $13 / 87$ \\
B & 22 & $100 / 0$ \\
\hline
\end{tabular}

Scheme 108. Synthesis of $(E)$ - and (Z)-5(bromomethylene)-2(5H)-furanone, (311) and (308), respectively

More recently, Benneche and coworkers synthesized in $77 \%$ yield a mixture of $(E)$ - and (Z)-5-(bromomethylene)$2(5 H)$-furanone in a $91: 9$ ratio, respectively, by reactiong 5-methoxyfurfural (312) with 1.13 equiv of oxalyl bromide (110) in $\mathrm{CH}_{2} \mathrm{Cl}_{2}$ (Scheme 109) [196].

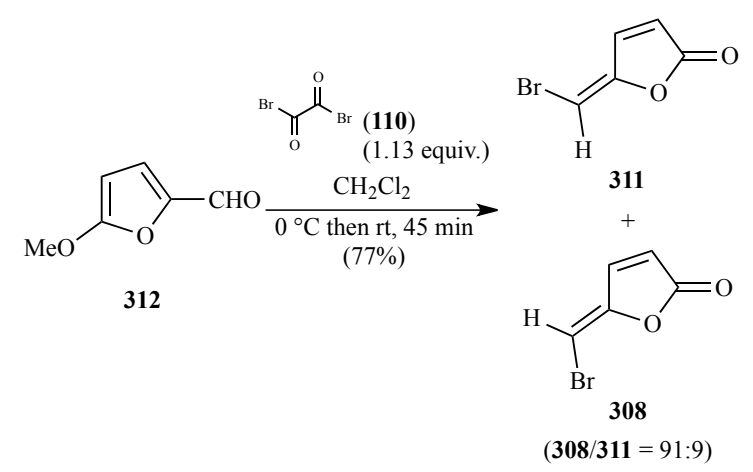

Scheme 109. Synthesis of a mixture of $(E)$ - and (Z)-5(bromomethylene)-2(5H)-furanone from 5methoxyfurfural (312)

(Z)-5-(Bromomethylene)-2(5H)-furanone (308) has also been the subject a several studies concerning its biological activity. In 2002, Givskov and coworkers reported that this compound is capable of interfering with $N$-acyl homoserine lactone (AHL)-mediated QS in Pseudomonas aeruginosa and demonstrated that it specifically represses expression of a PlasB-gfp reporter fusion without affecting growth or protein synthesis and reduces the production of important virulence factors [197]. They also applied $\mathbf{3 0 8}$ to $P$. aeruginosa biofilms and found that the green fluorescent protein (Gfp) analysis that $\mathbf{3 0 8}$ penetrates microcolonies and blocks cell signaling and QS in most biofilm cells [197].

In 2004, Wu and coworkers showed that $\mathbf{3 0 8}$ interfers with the action of AHL molecules and inhibits gene expression regulated by QS systems in P. aeruginosa in vivo [168]. These authors also found that $\mathbf{3 0 8}$ exerts favourable therapeutic effects in $P$. aeruginosa lung infections in mice [168].

In 2007, Lönn-Stensrud and coworkers found that $\mathbf{3 0 8}$ inhibits biofilm formation and bioluminescence induction by Streptococcus anginosus, S. intermedius and S. mutans as well as bioluminescence induction by Vibrio harveyi BB152 [198].

In 2013, Vestby and coworkers investigated the use of compound $\mathbf{3 0 8}$ against the establishment of biofilm by Salmonella serotype Agona and E. coli O103:H2 and found that this brominated furanone inhibits biofilm formation without being bactericidal [199]. They also demonstrated that 308 effects both swimming and swarming motility without, however, affecting the expression of flagella [199].

In the same year, Luk and coworkers carried out the synthesis of (Z)-5-(1-bromoethylidene)-2( $5 H)$-furanone (315) in three steps and $45 \%$ overall yield starting from 4 oxohexanoic acid (313) (Scheme 110) [200]. In particular, a $\mathrm{CH}_{2} \mathrm{Cl}_{2}$ solution of $\mathbf{3 1 3}$ was reacted with 2.0 equiv of bromine and a catalytic quantity of $40 \% \mathrm{HBr}$ at room temperature for $1 \mathrm{~h}$. The resulting crude dibromocarboxylic acid 314 was dissolved in $\mathrm{CH}_{2} \mathrm{Cl}_{2}$ and treated with 2.0 equiv of $\mathrm{P}_{4} \mathrm{O}_{10}$ at $0{ }^{\circ} \mathrm{C}$ for $0.5 \mathrm{~h}$ and then heated at reflux for $1.5 \mathrm{~h}$. Finally, the solid intermediate, which was obtained by centrifugation of the reaction mixture, was reacted with 1.03 equiv of $\mathrm{Et}_{3} \mathrm{~N}$ at $0{ }^{\circ} \mathrm{C}$ for $1 \mathrm{~h}$ and under reflux for $1 \mathrm{~h}$ providing $315(\mathrm{BF}-15)$ in $45 \%$ yield based on 313 (Scheme 110) [200]. 


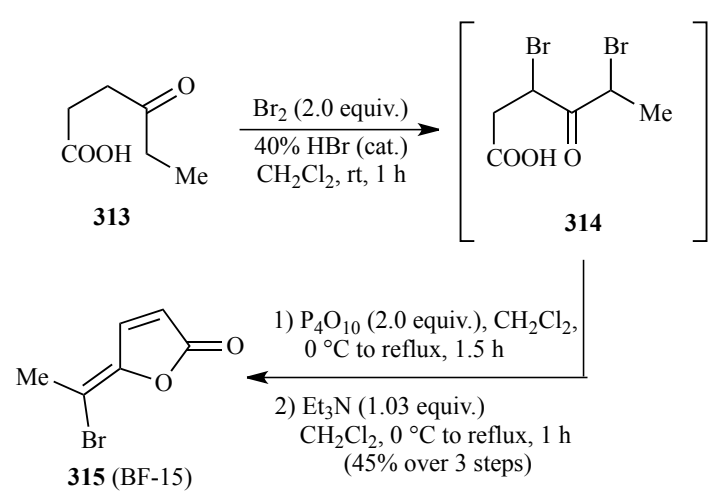

Scheme 110. Synthesis of (Z)-5-(1-bromoethylidene)2(5H)-furanone (315)

Interestingly, compound $\mathbf{3 1 5}$ was found capable to inhibit the production of the virulence factor elastase B of $P$. aeruginosa PAO1 with little inhibition of biofilm formation [200].

In 2012, 3-alkoxycarbonyl-5-aryl-5-bromomethyl2(5H)-furanones 318 were synthesized by Hassanabadi and coworkers via a one-pot process involving the reaction of phenacyl bromides 316 with equimolar amounts of dialkyl acetylenedicarboxylates 317 and 1.0 equiv of $\mathrm{PPh}_{3}$ in $\mathrm{CH}_{2} \mathrm{Cl}_{2}$ at room temperature for $24 \mathrm{~h}$ [201]. This protocol allowed the authors to prepare compounds $\mathbf{3 1 8 a}, \mathbf{3 1 8 b}$ and 318c in $88 \%, 6 \%$ and $92 \%$ yield, respectively (Scheme 111) [201].

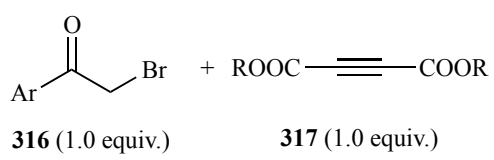

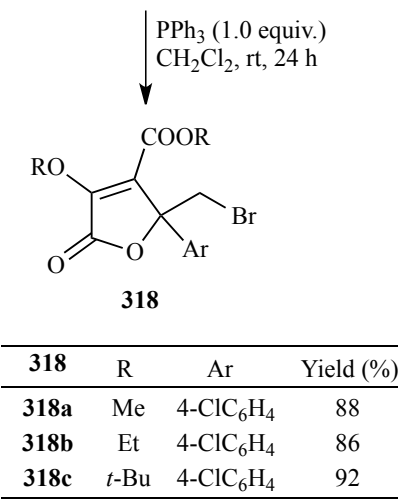

Scheme 111. One-pot synthesis of compounds 318a-c

In 2013, Soulère, Queneau and coworkers carried out the synthesis of (Z)-3-alkyl-5-(bromomethylene)-2(5H)furanones 324a and 324b, which are analogues of naturally-occurring bacterial QS inhibitors, via a novel reaction sequence in which $\alpha$-phenylthio- $\gamma$-buryrolactone (319) was used as the starting material (Scheme 112)

[202]. Specifically, treatment of $\mathbf{3 1 9}$ with LDA in THF at $78^{\circ} \mathrm{C}$ followed by addition of the required alkyl iodides in HMPA at $-78{ }^{\circ} \mathrm{C}$ gave 3-alkyl-3-phenylthiodihydrofuran$2(3 H)$-ones 320a and 320b in good yields. Subsequent oxidation-elimination reaction of these substances by treatment with $\mathrm{MCPBA}$ in $\mathrm{CH}_{2} \mathrm{Cl}_{2}$ at $0{ }^{\circ} \mathrm{C}$ provided compounds 321a and 321b in $81 \%$ and $86 \%$ yield, respectively. They were converted to the corresponding 5methylene-2(5H)-furanones 323a and 323b in $34 \%$ and $58 \%$ yield, respectively, by treatment with LDA in THF at $-78{ }^{\circ} \mathrm{C}$ and then with dimethylmethylideneammonium iodide (322) (Eschenmoser's salt). Finally, a bromine addition-elimination sequence [185] allowed to obtain compounds 324a and 324b in $56 \%$ and $37 \%$ yield, respectively (Scheme 112) [202].

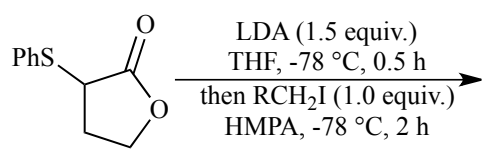

319<smiles>[R]CC1=CCOC1=O</smiles>

321a : $\mathrm{R}=n-\operatorname{Pr}(81 \%)$

321b : $\mathrm{R}=n$-Pent $(86 \%)$

$$
\begin{gathered}
\text { LDA }(1.5 \text { equiv. }), \mathrm{THF} \\
-78^{\circ} \mathrm{C}, 1 \mathrm{~h} \text { then } \\
\underset{\left[\mathrm{CH}_{2} \mathrm{~N}^{+} \mathrm{Me}_{2}\right] \mathrm{I}^{-}(322)(7.0 \text { equiv. })}{1 \mathrm{~h},-78^{\circ} \mathrm{C}, \mathrm{rt}, 2 \mathrm{~h}}
\end{gathered}
$$

320a $: \mathrm{R}=n-\operatorname{Pr}(76 \%)$

320b : $\mathrm{R}=n$-Pent $(64 \%)$

$\frac{\operatorname{MPCBA}(1.5 \text { equiv. })}{\mathrm{CH}_{2} \mathrm{Cl}_{2}, 0{ }^{\circ} \mathrm{C}, 20 \mathrm{~min}}$

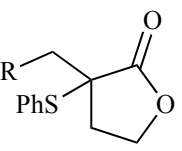




$$
\text { 319 }
$$

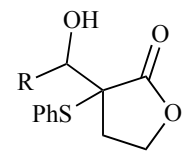

325a $: \mathrm{R}=n-\operatorname{Pr}(80 \%)$

325b : $\mathrm{R}=n$-Pent $(55 \%)$

325c : $\mathrm{R}=n$-Hept $(69 \%)$<smiles>[R]C(O)C1=CCOC1=O</smiles>

326a $: \mathrm{R}=n-\operatorname{Pr}(78 \%)$

326b : $\mathrm{R}=n$-Pent $(84 \%)$

326c : $\mathrm{R}=n$-Hept $(71 \%)$

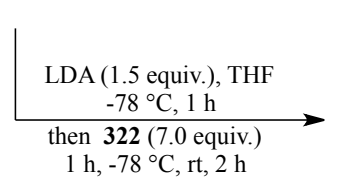

$1 \mathrm{~h},-78^{\circ} \mathrm{C}, \mathrm{rt}, 2 \mathrm{~h}$

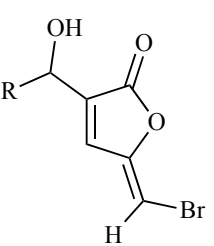

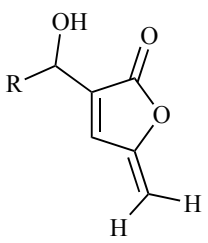

327a $: \mathrm{R}=n-\operatorname{Pr}(54 \%)$

327b : $\mathrm{R}=n$-Pent $(63 \%)$

$327 \mathrm{c}: \mathrm{R}=n$-Hept $(42 \%)$ 328a $: \mathrm{R}=n-\operatorname{Pr}(48 \%)(E / Z=12: 88)$

328b : $\mathrm{R}=n$-Pent $(31 \%)$

328c : $\mathrm{R}=n$-Hept $(49 \%)$

Scheme 113. Synthesis of (Z)-5-(bromomethylene)-3[1-(hydroxyalkyl)]-2(5H)-furanones 329a-c

The reaction of $\mathbf{3 1 9}$ with 1.5 equiv of LDA in THF at $78{ }^{\circ} \mathrm{C}$ for $0.5 \mathrm{~h}$ followed by addition of 1.0 equiv of the required alkyl aldehydes in HMPA at $-78{ }^{\circ} \mathrm{C}$ produced compounds 325 a-c in yields ranging from $55 \%$ to $80 \%$. An oxidative elimination reaction, which was carried out by treatment of 325a-c with 1.5 equiv of MCPBA in $\mathrm{CH}_{2} \mathrm{Cl}_{2}$ at $0{ }^{\circ} \mathrm{C}$ gave 3-(1-hydroxyalkyl)-2(5H)-furanones 326a-c in high yields. These compounds were then efficiently converted to the corresponding 5-methylene derivatives, $\mathbf{3 2 7} \mathbf{a}-\mathbf{c}$, in satisfactory yields by using Eschenmoser's salt 322. Finally, a bromine additionelimination sequence, which was carried out by a procedure identical to that used to prepare compounds 324a,b, provided 328a in $48 \%$ yield and $88 \%$ stereoisomeric purity, and stereoisomerically pure compounds 328b and 328c in $31 \%$ and $49 \%$ yield, respectively (Scheme 113) [202].

Soulère, Queneau and coworkers also tested compounds 324a, 324b, 325a-b, 328a-c, and 329a-c for their ability to inhibit the Vibrio fischeri QS system and found thay $(Z)-3$ butyl-5-(bromomethylene)-2(5H)-furanone (325a) with an $\mathrm{IC}_{50}$ of $0.6 \mu \mathrm{M}$ was the most active compound among all these fimbrolide analogues. It was also verified that, for this substance, the bioluminescence inhibition did not result from antimicrobial activity rather than QS inhibition [202].

In 2014, in a study on the effect of bicyclic brominated furanones $(\mathrm{BBF})$ on $\mathrm{QS}$, Wang, Luk and coworkers synthesized compounds 329 (5-BBF), 330 (6-BBF) and 331 (7-BBF) (Figure 23) [25].<smiles>O=C1C=C2CCC(Br)=C2O1</smiles>

329 (5-BBF)<smiles>O=C1C=C2CCCC(Br)=C2O1</smiles>

330 (6-BBF)<smiles>O=C1C=C2CCCCC(Br)=C2O1</smiles>

331 (7-BBF)
Figure 23. Structures of bicyclic brominated furanones 329-331

The synthesis of compound $\mathbf{3 2 9}$ was carried out in only $3 \%$ yield by treatment of 2-oxocyclopentaneacetic acid (332) with 1.95 equiv of bromine at $0{ }^{\circ} \mathrm{C}$ for $40 \mathrm{~min}$ and then at room temperature for $100 \mathrm{~min}$, followed by cyclization of the resulting dibrominated carboxylic acid 333 with $\mathrm{P}_{2} \mathrm{O}_{5}$ in $\mathrm{CH}_{2} \mathrm{Cl}_{2}$ at $0{ }^{\circ} \mathrm{C}$ for $0.5 \mathrm{~h}$ and then under reflux for $2 \mathrm{~h}$. Finally, dehydrobromination of the resulting crude compound 334 by treatment with 1.04 equiv of $\mathrm{Et}_{3} \mathrm{~N}$ at first at $0{ }^{\circ} \mathrm{C}$ and then under reflux for $2 \mathrm{~h}$ gave compound 329 (5-BBF) (Scheme 114) [25].

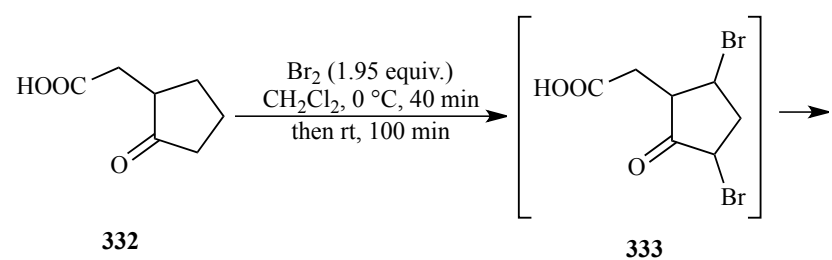

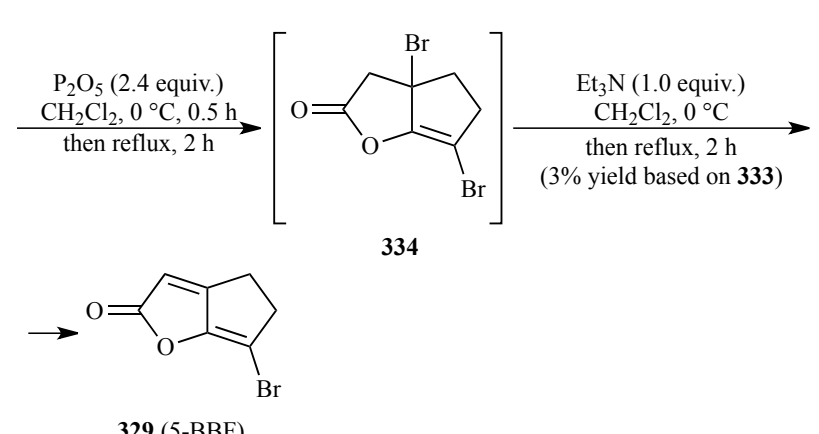

Scheme 114. Synthesis of compound 329 (5-BBF)

A similar reaction sequence involving 2oxocyclohexaneacetic acid (336), which was obtained by saponification of the corresponding ethyl ester $\mathbf{3 3 5}$ allowed for the preparation of compound 330 (6-BBF) in $16 \%$ overall yield (Scheme 115) [25]. 


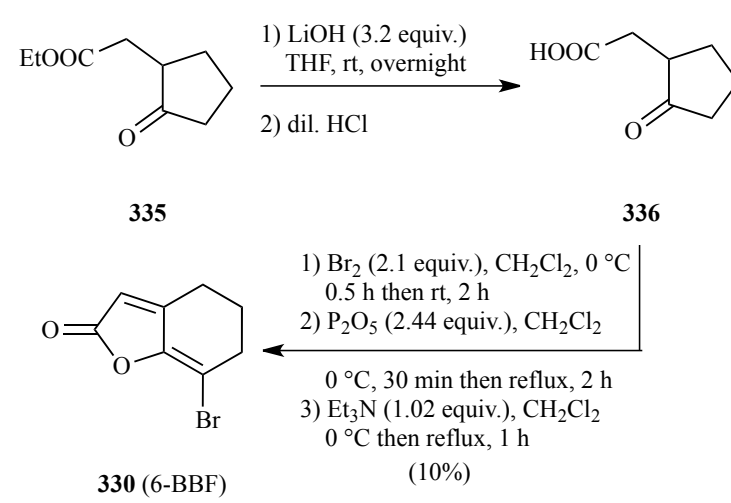

Scheme 115. Synthesis of compound 330 (6-BBF)

The synthesis of 331 (7-BBF) was instead carried out starting from cycloheptanone (337) (Scheme 116). Specifically, 337 was reacted with 3.56 equiv of $\mathrm{NaH}$ in benzene and the resulting enolate was treated with 2.5 equiv of dimethyl carbonate (338) providing crude methyl 2-oxo-1-cycloheptanecarboxylate (339). An acetone solution of $\mathbf{3 3 9}$ was then treated with 4.7 equiv of $\mathrm{K}_{2} \mathrm{CO}_{3}$ and 0.94 equiv of ethyl bromoacetate (340) and the resulting mixture was refluxed for $17 \mathrm{~h}$. The oil, which was obtained after concentration of the reaction mixture, was treated with a mixture of $6 \mathrm{M} \mathrm{HCl}$ and acetic acid providing compound $\mathbf{3 4 1}$ in $87 \%$ yield based on $\mathbf{3 3 7}$. Finally, dibromination of this intermediate, dehydration and $\mathrm{Et}_{3} \mathrm{~N}$-mediated elimination produced compound $\mathbf{3 3 1}$ (7-BBF) in 10\% yield (Scheme 116) [25].

Next, 5-BBF, 6-BBF and 7-BBF were found to interfere with QS and QS-controlled activitites in Gram-negative bacteria. In fact, these compounds appeared able to inhibit biofilm formation by $E$. coli and P. aeruginosa and to inhibit elastase $\mathrm{B}$ production by $P$. aeruginosa at nonmicrobicidal concentrations [25]. The effect of compounds 5-BBF, 6-BBF and 7-BBF on biofilm formation of $P$. aeruginosa was investigated using a wild strain PA01-GFP, which constitutively expresses green fluorescence proteins [203] and enables easy and direct visualization of biofilm. In the initial screening, it was found that, at $400 \mu \mathrm{M}, 6-\mathrm{BBF}$ provided more inhibition than 5-BBF and 7-BBF. Results were also obtained showing that 6-BBF and 7-BBF exhibit antagonistic activities for the transcriptional activator LasR protein in the lasl QS circuit in P. aeruginosa, while 5-BBF is a strong agonist of the rhil QS circuit [25].
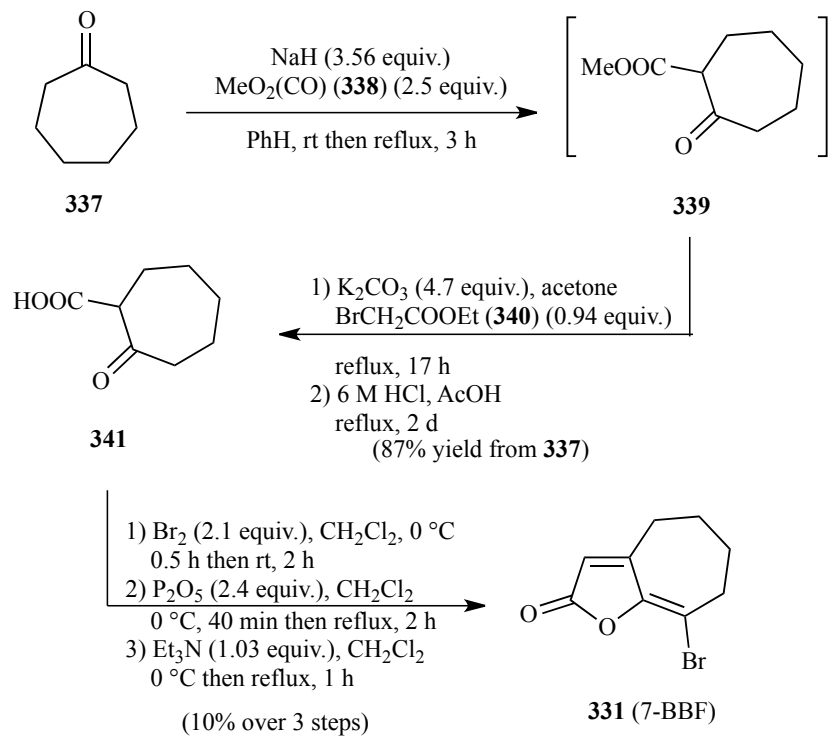

Scheme 116. Synthesis of compound 331 (7-BBF)

In the last two decades, significant interest has also been directed to the synthesis and evaluation of the biological properties of $2(5 H)$-furanones featuring monobrominated aryl substituents. In 2000, Pour and coworkers synthesized racemic 3-(3-bromophenyl)-5-methyl- and 3-(4bromophenyl)-5-methyl-2(5H)-furanone, (344a) and (344b), respectively, by conversion of saturated lactones 342a and 342b with LDA, reaction of the resulting enolates with phenylselenyl chloride (343), and oxidation with MCPBA with spontaneous selenoxide elimination of the resulting $\alpha$-selenyl derivatives (Scheme 117) [204].

Compounds 344a and 344b were then evaluated for their in vitro antifungal activity against a set of clinical isolates of human pathogenic fungi and it was found that their minimal inhibitory concentration (MIC) against Candida albicans after $24 \mathrm{~h}$ was $7.81 \mu \mathrm{mol} / \mathrm{L}$ for $344 \mathrm{a}$ and $31.25 \mu \mathrm{mol} / \mathrm{L}$ for $\mathbf{3 4 4 b}$. In addition, the MIC values for 344a and 344b against Trichophyton mentagrophytes after $72 \mathrm{~h}$ were proven to be 31.25 and $6.25 \mu \mathrm{mol} / \mathrm{L}$, respectively, and to double after $120 \mathrm{~h} \mathrm{[204].}$

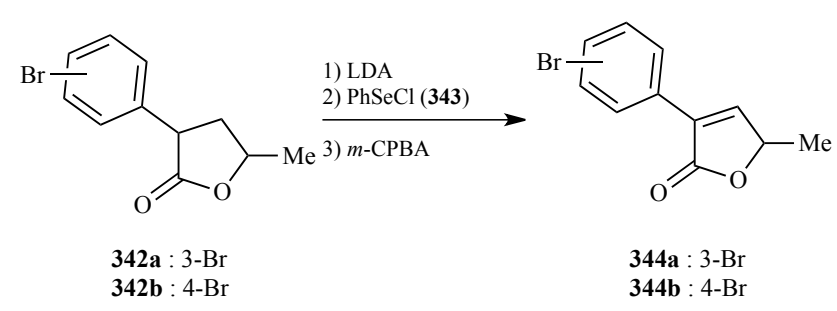

Scheme 117. Synthesis of 3-(bromophenyl)-5-methyl$2(5 H)$-furanones $\mathbf{3 4 4 a , b}$

In 2001, Pour and coworkers prepared racemic 3-(4bromophenyl)-5-(hydroxymethyl)-2(5H)-furanone 
(Figure 24) from the corresponding saturated lactone 346 (Figure 24) using a reaction sequence similar to that depicted in Scheme 117 [205]. Compound 346 was in turn synthesized from (4-bromophenyl)acetic acid (345) (Figure 24) via a five-step route [205].

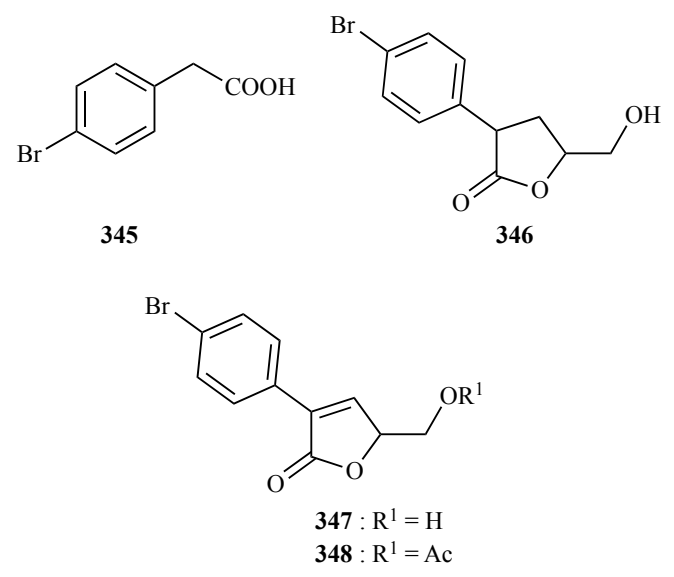

Figure 24. Structures of compounds 345-348

Compound $\mathbf{3 4 7}$ was subsequently converted to the corresponding acetate 348 (Figure 21) by acylation with acetyl chloride in $\mathrm{CH}_{2} \mathrm{Cl}_{2}$ at $0{ }^{\circ} \mathrm{C}$ in the presence of pyridine [205].

Compounds 347 and 348 were then evaluated for their antifungal activity against a set of human pathogenic fungi including the representatives of both yeast and filamentous strains and found that $\mathbf{3 4 7}$ exhibited a moderate antifungal effect which was much lower than that of the corresponding acetate $\mathbf{3 4 8}$, a relatively lipophilic compound [205].

In 2004, compound 348, also indicated as LNO18-22, was found to exhibit a broad spectrum of activity against a variety of pathogenic yeasts and molds including Candida albicans, C. incospicua, C. krusei, Blastoschizomyces capitatus, the Trichosporon beigelii complex, and Aspergillus species with decreased susceptibility to fluconazole [206].

In 2006, the mechanism of action of $\mathbf{3 4 8}$ against Candida albicans was investigated by Vale-Silva and coworkers by using flow cytometry [207]. They determined that the potent fungicidal activity of this compound resulted in disruption of the plasmatic cell membrane of C. albicans.

Four years later, Pour and coworkers converted compound 347 to 5-methylene-3-(4-bromophenyl)-2(5H)furanone (349) in $64 \%$ yield by treatment with 1.2 equiv of $\mathrm{PPh}_{3}, 1.2$ equiv of iodine and 1.2 equiv of imidazole in dry $\mathrm{CH}_{2} \mathrm{Cl}_{2}$ at $-10{ }^{\circ} \mathrm{C}$ and then at room temperature (Scheme 118) [208]. They then observed that $\mathbf{3 4 9}$ exhibited excellent activity against $C$. albicans ATCC44859 and $C$. glabrata strain and that this activity was identical to that of its precursor 347. Compound 349 was also found to possess moderate cytostatic activity against CCRF-CEM cell lines. Moreover, cell cycle analysis of CCRF-CEM cells following treatment with $\mathbf{3 4 9}$ showed that this furanone is a necrotic agent [208].<smiles>O=C1OC(CO)C=C1c1ccc(Br)cc1</smiles>

347

$\mathrm{PPh}_{3}$ (1.2 equiv.)

$\mathrm{I}_{2}$ (1.2 equiv.)

imidazole ( 1.2 equiv.)

$\mathrm{CH}_{2} \mathrm{Cl}_{2},-10^{\circ} \mathrm{C}$ to $\mathrm{rt}$<smiles>C=C1C=C(c2ccc(Br)cc2)C(=O)O1</smiles>

349

Scheme 118. Synthesis of 5-methylene-3-(4bromophenyl)-2(5H)-furanone (349)

In 2015, 3-(bromophenyl)-5,5-dimethyl-2(5H)furanones 352a-c were efficiently synthesized by Mao and Zhu by using a practical and atom-economical method that involved the $\mathrm{BF}_{3} \cdot \mathrm{Et}_{2} \mathrm{O}$ catalyzed, $p$ - $\mathrm{TsOH} \cdot 2 \mathrm{H}_{2} \mathrm{O}$-mediated annulation of 2-methylpropan-2-ol (350) with the required bromophenylglyoxylic acids 351 (Scheme 119) [209]. Specifically, the reaction of compounds $351 \mathrm{a}-\mathrm{c}$ with 1.5 equiv of 350 in $o$-xylene at $110{ }^{\circ} \mathrm{C}$ in the presence of 20 mol\% $\mathrm{BF}_{3} \cdot \mathrm{Et}_{2} \mathrm{O}$ and 2.5 equiv of $p$ - $\mathrm{TsOH} \cdot 2 \mathrm{H}_{2} \mathrm{O}$ produced compounds 352a, 352b and 352c in $42 \%, 77 \%$ and $82 \%$ yield, respectively [209]. 
<smiles>[Y4]C([14CH3])(O)C[13CH3]</smiles>

$\mathbf{3 5 0}$ (1.5 equiv.) $\mathbf{3 5 1}$ (1.0 equiv.)

$$
\mid \begin{aligned}
& \mathrm{BF}_{3} \mathrm{Et}_{2} \mathrm{O}(20 \mathrm{~mol} \%) \\
& p \text {-TsOH } \bullet 2 \mathrm{H}_{2} \mathrm{O}(2.5 \text { equiv. }) \\
& o \text {-xylene, } 110^{\circ} \mathrm{C}, 5-9 \mathrm{~h}
\end{aligned}
$$<smiles>CC1(C)C=C(c2ccc(Br)cc2)C(=O)O1</smiles>

352a : $2-\operatorname{Br}(42 \%)$

352b : $3-\operatorname{Br}(77 \%)$

352c : $4-\mathrm{Br}(82 \%)$

Scheme 119. Synthesis of 3-(bromophenyl)-5,5dimethyl-2(5H)-furanones 352a-c

In 2012, 2(5H)-furanone 355 was synthesized by Manna and Mukherjee in 93\% yield with high diastereo- and enantioselectivity by asymmetric direct vinylogous Michael reaction between $\alpha$-angelica lactone (353) and $N$ 4-bromophenylmaleimide (354) in $\mathrm{CH}_{2} \mathrm{Cl}_{2}$ at $-35^{\circ} \mathrm{C}$ in the presence of $5 \mathrm{~mol} \%$ the thiourea homochiral catalyst TTC (Scheme 120) [210].<smiles>CC1=CCC(=O)O1</smiles>

$$
353 \text { (1.0 equiv.) } \quad 354 \text { (1.1 equiv.) }
$$

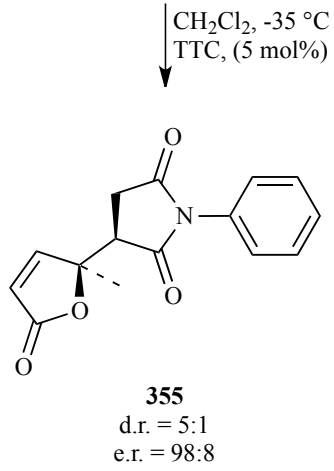

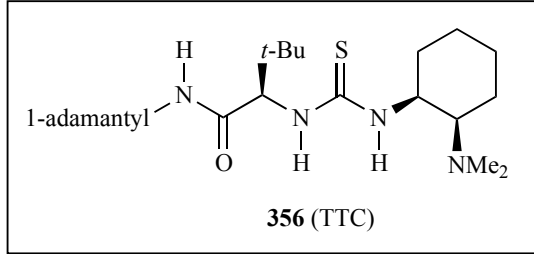

Scheme 120. Asymmetric synthesis of $2(5 H)$-furanone 355

In 2015, Nakamura and coworkers reported that treatment of $N$-diphenylphosphinoylketimine 357 with 2.0 equiv of 2(5H)-furanone (12), $10 \mathrm{~mol} \% \mathrm{Zn}(\mathrm{OTf})_{2}, 10$ mol\% cinchona alkaloid amide (CAA) and 1.0 equiv of $\mathrm{Et}_{3} \mathrm{~N}$ in $\mathrm{THF}$ at $0{ }^{\circ} \mathrm{C}$ for $24 \mathrm{~h}$ in the presence of $4 \AA$ molecular sieves produced in $92 \%$ yield a $1: 99$ mixture of syn- and anti-furanone 358 in which the e.r. for the antiisomer was $93: 7$ (Scheme 121) [211]. Compound 357, which was used in this asymmetric direct vinylogous Mannich reaction, was prepared from the corresponding methyl aryl ketone by using a literature procedure [212].

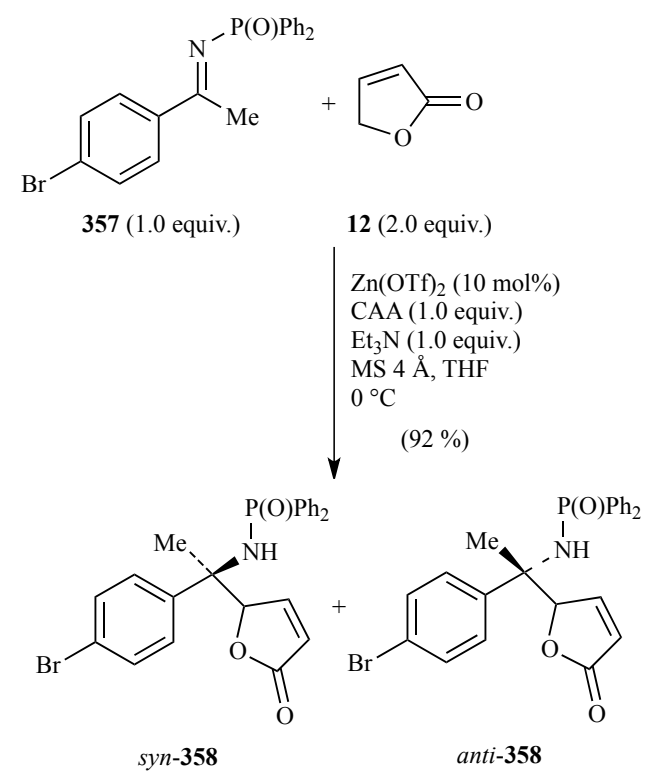

Scheme 121. Enantioselective synthesis of anti-2(5H)furanone $\mathbf{3 5 8}$

Still in 2015, Franck and coworkers synthesized some analogues of cadiolide A (359a), cadiolide B (359b) and cadiolide C (359c) (Figure 25) [213], three brominated, densely functionalized $2(5 \mathrm{H})$-furanone derivatives which were isolated in 1998 from an Indonesian ascidian of the genus Botryllus [214] and in 2012 from the Korean tunicate Pseudodistoma antiboja [215]. 


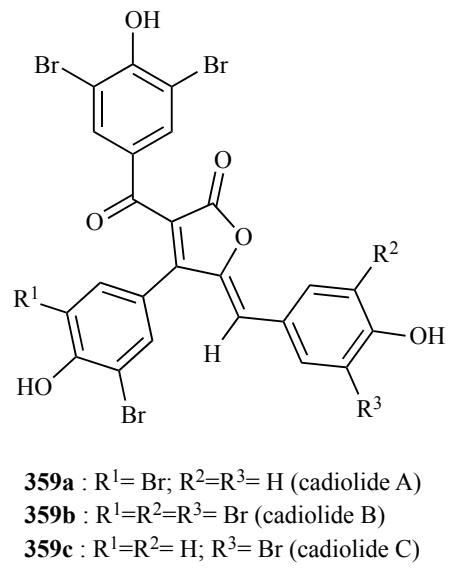

Figure 25. Structures of cadiolide A (359a), cadiolide B (359b) and cadiolide C (359c)

These analogues, which included 2(5H)-furanones featuring monobrominated phenyl substituents, were evaluated against four Gram-positive bacterial strains,
Bacillus cereus, B. subtilis, Staphylococcus aureus and Enterococcus faecalis, and four Gram-negative bacterial strains, Salmonella typhi, E. coli 100, E. coli 405 and Erwinia carotovora. Among the analogues with monobrominated substituents, (Z)-3-(3-bromo-4hydroxybenzoyl)-5-(3-bromo-4-hydroxybenzylidene)-4-(3bromo-4-hydroxyphenyl)-2(5H)-furanone (362) was the most potent compound with a MIC value of $1.95 \mu \mathrm{g} / \mathrm{mL}$ against B. cereus, S. aureus, E. faecalis, S. typhi and E. coli 405 [213].

This compound was synthesized in $44 \%$ yield by a onepot process involving the reaction of $\alpha$-hydroxyketone $\mathbf{3 6 0}$ with 2.0 equiv of dioxinone 361, 1.0 equiv of aldehyde 228 and 2.0 equiv of $\mathrm{Et}_{3} \mathrm{~N}$ in toluene at $150{ }^{\circ} \mathrm{C}$ under microwave irradiation for $15 \mathrm{~min}$ and the subsequent $O$ demethylation of the resulting crude product by treatment with 10 equiv of $\mathrm{BBr}_{3}$ in $\mathrm{CH}_{2} \mathrm{Cl}_{2}$ at room temperature for $20 \mathrm{~h} \quad$ (Scheme 122) [213].<smiles>COc1ccc(C(=O)CO)cc1Br</smiles>

Scheme 122. One-pot synthesis of (Z)-3-(3-bromo-4-hydroxybenzoyl)-5-(3-bromo-4-hydroxybenzylidene)-4-(3-bromo-4hydroxyphenyl)-2(5H)-furanone (362)

Interestingly, a similar one-pot procedure was used to prepare cadiolide analogues 363, 364 and 365 (Figure 26) in $38 \%, 37 \%$ and $30 \%$ yield, respectively [213]. 
<smiles>O=C1OC(=Cc2ccc(O)c(Br)c2)C(c2ccc(O)cc2)=C1C(=O)c1ccc(O)c(Br)c1</smiles><smiles>O=C1O/C(=C\c2ccc(O)c(Br)c2)C(c2ccc(O)c(Br)c2)=C1C(=O)c1ccco1</smiles><smiles>O=C1O/C(=C\c2ccc(O)c(Br)c2)C(c2ccc(O)c(Br)c2)=C1C(=O)c1ccc(O)cc1</smiles>

Figure 26. Structures of cadiolide analogues 363-365

\section{SYNTHESIS AND BIOACTIVITY OF 2(5H)- FURANONE DERIVATIVES FEATURING DIBROMINATED SUBSTITUENTS}

As mentioned in Section 6, in 2004, Brückner and coworkers synthesized 5-(dibromomethylene)-2 $(5 H)$ furanone (305) by treatment of 3,5-dibromolevulinic acid (144) with a $2: 1$ mixture of oleum and concd. sulfuric acid at $50-60{ }^{\circ} \mathrm{C}$ (Scheme 106) [102].

In 2008, Ren, Luk and coworkers reported that the reaction of $\alpha$-methyllevulinic acid (248) with 2 equiv of bromine at $35-40{ }^{\circ} \mathrm{C}$ for $1 \mathrm{~h}$, followed by treatment of the resulting crude reaction mixture with $95-98 \%$ sulfuric acid at $110{ }^{\circ} \mathrm{C}$ for $20 \mathrm{~min}$ gave a mixture of 5(dibromomethylene)-3-methyl-2(5H)-furanone (250) (BF9), 4-bromo-5-(dibromomethyl)-3-methyl-2( $5 H)$-furanone (251) (BF-14) and (E)-4-bromo-5-(bromomethylene)-3-
methyl-2(5H)-furanone (249) (BF-8) in 12\%, 2.7\% and $13 \%$ yield, respectively (Scheme 90) [174]. These authors also found that the reaction of compound $\mathbf{2 5 0}$ with 2.0 equiv of NBS in $\mathrm{CCl}_{4}$ under reflux for $12 \mathrm{~h}$ in the presence of a catalytic quantity of dibenzoyl peroxide gave 3(dibromomethyl)-5-(dibromomethylene)-2(5H)-furanone (269) (BF-10) and 3-(bromomethyl)-5-dibromomethylene$2(5 H)$-furanone (268) (BF-11) in $13 \%$ and $50 \%$ yield, respectively (Scheme 96) [174]. Interestingly, compounds 250 (BF-9) and 269 (BF-10) exhibited strong biofilm inhibition by $E$. coli at $60 \mu \mathrm{g} / \mathrm{mL}$ without effects on $E$. coli growth [174].

In 1997, Kotora and Negishi carried out the first total synthesis of rubrolide C (374) [216], a metabolite of the colonial tunicate Ritterella rubra which is a member of a family of compounds that are potent in vitro antibiotics and show moderate but selective inhibition of protein phosphatases I and 2A [48]. Scheme 123 outlines the reaction sequence used for the synthesis of this natural product. 

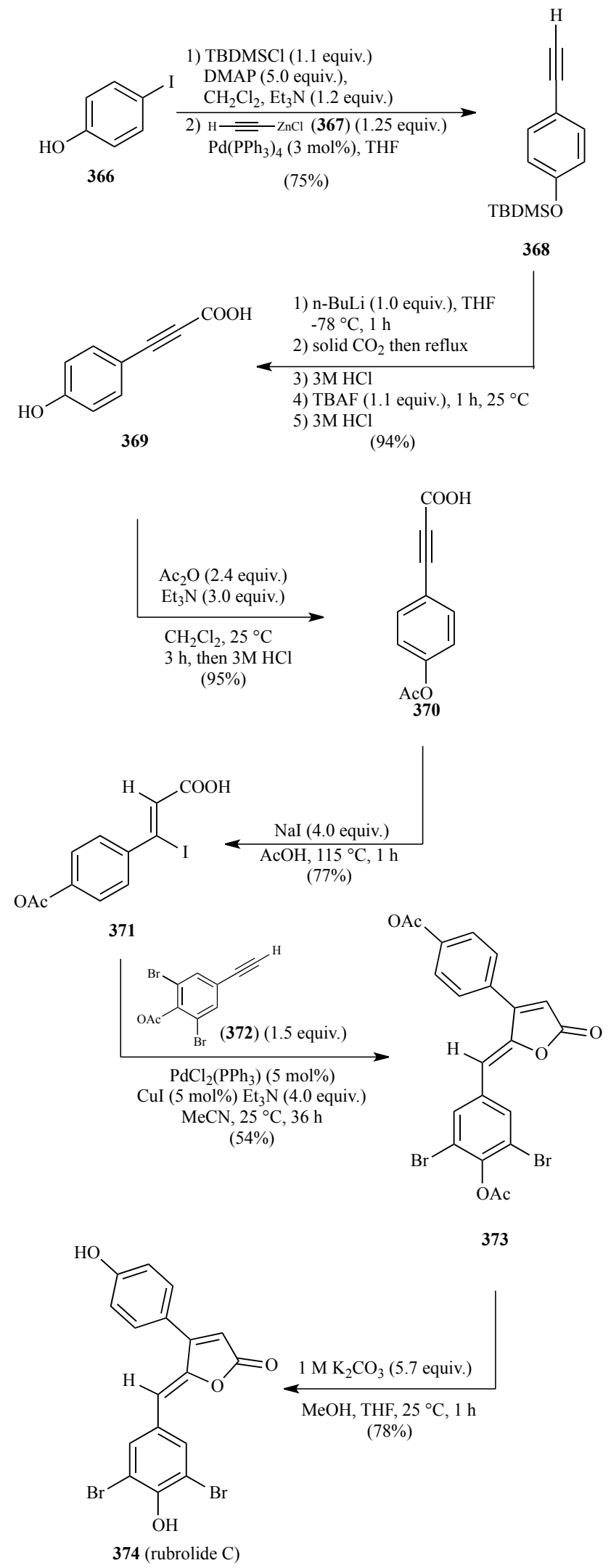

Scheme 123. First total synthesis of rubrolide $C$ (374)
Thus, protection of the phenol group of 4-iodophenol (366) as TBDMS ether, followed by Pd-catalyzed reaction with ethynylzinc chloride (367) gave 1-alkyne $\mathbf{3 6 8}$ in 75\% yield. This compound was then converted to 3(hydroxyphenyl)propynoic acid (369), which was reacted with $\mathrm{Ac}_{2} \mathrm{O}$ and $\mathrm{Et}_{3} \mathrm{~N}_{\mathrm{i}}$ in $\mathrm{CH}_{2} \mathrm{Cl}_{2}$ and subsequently with $3 \mathrm{M}$ $\mathrm{HCl}$ providing 3-(4-acetoxyphenyl)propynoic acid (370) in $95 \%$ yield. Hydroiodination of $\mathbf{3 7 0}$ by treatment with $\mathrm{NaI}$ and $\mathrm{AcOH}$ at $115^{\circ} \mathrm{C}$ gave stereoselectively and in a good yield (Z)-3-(4-acetoxyphenyl)-3-iodoprop-2-enoic acid (371) which underwent $\mathrm{PdCl}_{2}\left(\mathrm{PPh}_{3}\right)_{2} / \mathrm{CuI}$-catalyzed crosscoupling/lactonization reaction by treatment witth 1-alkyne 372 in acetonitrile in the presence of $\mathrm{Et}_{3} \mathrm{~N}$. The reaction led to rubrolice $\mathrm{C}$ diacetate (373) in $54 \%$ yield. Finally, treatment of 373 with $1 \mathrm{M} \mathrm{K}_{2} \mathrm{CO}_{3}$ in a mixture of $\mathrm{MeOH}$ and THF gave rubrolide C (374) in 78\% yield [216].

In 1998, Boukouvalas and coworkers described another synthesis of rubrolide C (Scheme 124) [47] that involved a lower number of steps compared to that reported by Kotora and Negishi [216] and was higher yielding. The Pdcatalyzed Suzuki-Miyaura cross-coupling of 4-bromo$2(5 H)$-furanone $(\mathbf{1 0 8})$ with arylboronic acid 301, which gave compound $\mathbf{3 7 5}$ in $79 \%$ yield, was first step of this new synthesis.

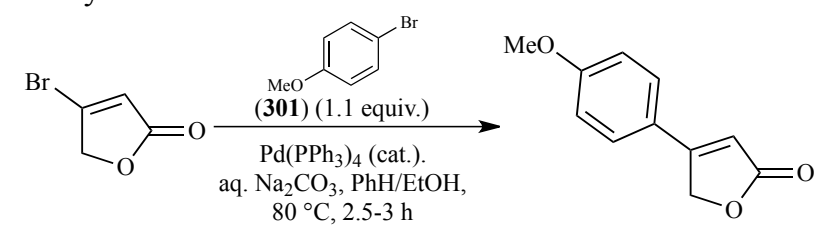

110

$(79 \%)$

375<smiles>COc1ccc(C2=CC(=O)O/C2=C\c2cc(Br)c(OC)c(Br)c2)cc1</smiles>
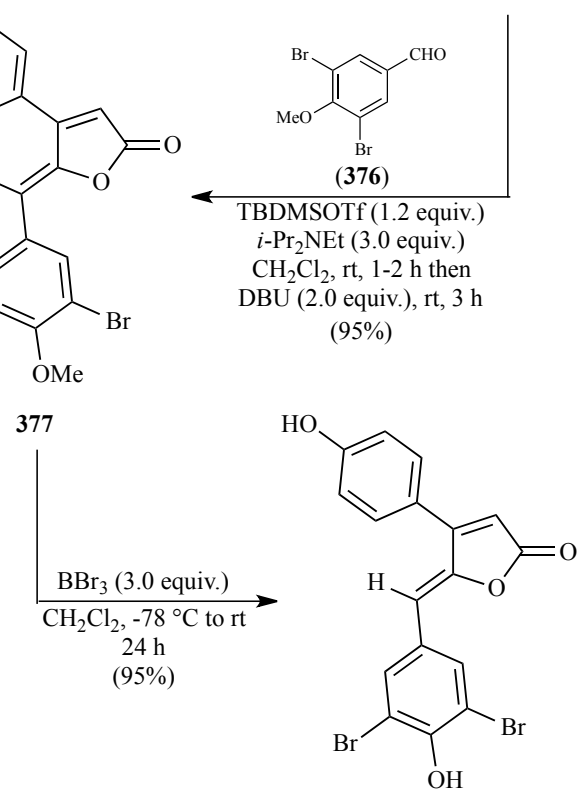

374 (rubrolide C)

Scheme 124. Synthesis of rubrolide C (374) from 4bromo-2(5H)-furanone (110) 
Aldolization of $\mathbf{3 7 5}$ with aldehyde $\mathbf{3 7 6}$ in the presence of TBDMSOTf and $i$ - $\mathrm{Pr}_{2} \mathrm{NEt}$, followed by treatment with DBU gave stereoisomerically pure compound 377 in $95 \%$ yield. Finally, exposure of 377 to 3 equiv of $\mathrm{BBr}_{3}$ in $\mathrm{CH}_{2} \mathrm{Cl}_{2}$ led to rubrolide $\mathrm{C}(\mathbf{3 7 4})$ in $95 \%$ yled [47].

More recently, Karade and coworkers reported a new efficient synthesis of rubrolide $C$ (Scheme 125) in which the preparation of compound $\mathbf{3 7 4}$ via intramolecular Wittig reaction of 2-(4-methoxyphenyl)-2-oxoethyl 2- bromoacetate (380) with $\mathrm{PPh}_{3}$ in the presence of $\mathrm{Et}_{3} \mathrm{~N}$ was a key step [217]. Conpound $\mathbf{3 8 0}$ was in turn obtained in $69 \%$ yield by treatment of 4-methoxyacetophenone (378) with 1.2 equiv of hydroxyl(tosyloxy)iodobenzene (known as Koser reagent) in acetonitrile under reflux, followed by entrapment of the resulting compound with bromoacetic acid (379) in the presence of $\mathrm{K}_{2} \mathrm{CO}_{3}$. The synthesis of rubrolide $\mathrm{C}$ was then completed in high yield by Knoevenagel condensation of $\mathbf{3 7 5}$ with aldehyde $\mathbf{3 7 6}$ and $O$-demethylation of the resulting compound 382 (Scheme 125)

[217].

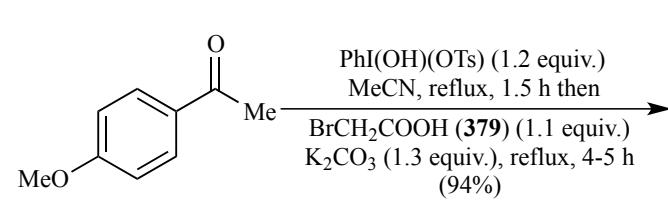

378<smiles>COc1ccc(C(=O)COC(=O)CBr)cc1</smiles>

380<smiles>COc1ccc(C2=CC(=O)OC2)cc1</smiles>

375
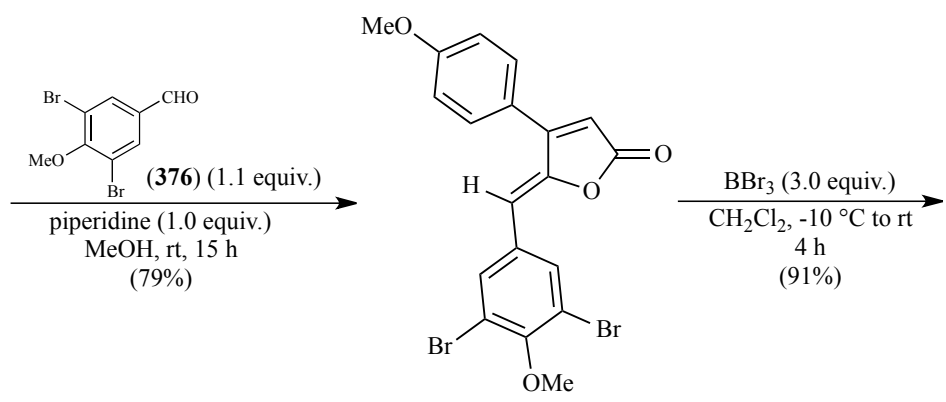

377<smiles>O=C1C=C(c2ccc(O)cc2)C(=Cc2cc(Br)c(O)c(Br)c2)O1</smiles>

374 (rubrolide C)

Scheme 125. Synthesis of rubrolide C (374) from 4-methoxyacetophenone (378)

In 2010, Boukouvalas and coworkers carried out the first synthesis of rubrolide L \{3-chloro-5-[(3,5-dibromo-4hydroxyphenyl)methylene]-4-hydroxyphenyl-2(5H)-

furanone (387) [218], an antitumor metabolite of the ascidian Synoicum blochmanni [49], which was found to inhibit human aldose reductase at submicromolar level [219]. The synthesis of $\mathbf{3 8 7}$ was achieved via two distinct pathways. In the first of these (Scheme 126), commercially available 3-chlorotetronic acid (382) was converted to triflate 383 in $73 \%$ yield. The chemoselective SuzukiMiyaura cross-coupling reaction of $\mathbf{3 8 3}$ with 1.2 equiv of arylboronic acid $\mathbf{3 0 1}$ in a mixture of toluene an water in the presence of a $\mathrm{Pd}(\mathrm{OAc})_{2} / \mathrm{PCy}_{3}$ catalyst system, $5 \mathrm{~mol} \%$ $\mathrm{BnEt}_{3} \mathrm{NCl}$ and $\mathrm{Na}_{2} \mathrm{CO}_{3}$ as the base gave 3-chloro-4methoxyphenyl-2(5H)-furanone (384) in $87 \%$ yield. The subsequent aldolization reaction of $\mathbf{3 8 4}$ with aldehyde $\mathbf{3 8 5}$ in the presence of TBDMSOTf and $i$ - $\operatorname{Pr}_{2} \mathrm{NEt}$, followed by treatment with DBU provided stereoisomerically pure $\mathbf{3 8 6}$ in $61 \%$ yield, which was then converted to rubrolide $\mathrm{L}$ (387) in $95 \%$ yield by $\mathrm{BBr}_{3}$-mediated $O$-demethylation (Scheme 126) [218]. 
<smiles>O=C1OCC(O)=C1Cl</smiles>
$\underset{\mathrm{Tf}_{2} \mathrm{O}(1.2 \text { equiv. })}{\mathrm{Et}_{3} \mathrm{~N}(1.2 \text { equiv. })}$
$\underset{\mathrm{CH}_{2} \mathrm{Cl}_{2}, 0^{\circ} \mathrm{C} \text { to rt, } 2 \mathrm{~h}}{(73 \%)}$ 382

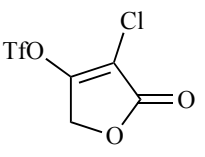

383<smiles>COc1ccc(C2=C(Cl)C(=O)OC2)cc1</smiles>

384

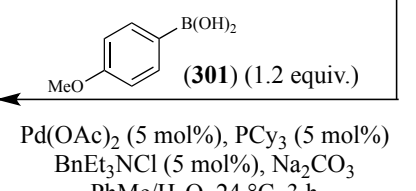

$\mathrm{BnEt}_{3} \mathrm{NCl}(5 \mathrm{~mol} \%), \mathrm{Na}_{2} \mathrm{CO}_{3}$
$\mathrm{PhMe} / \mathrm{H}_{2} \mathrm{O}, 24{ }^{\circ} \mathrm{C}, 3 \mathrm{~h}$

(87\%)<smiles>COc1ccc(C2=C(Cl)C(=O)O/C2=C\c2cc(Br)c(O)c(Br)c2)cc1</smiles>

Scheme 126. Synthesis of rubrolide L (387) using compound $\mathbf{3 8 6}$ as an advanced intermediate

The second protocol used for the synthesis of $\mathbf{3 8 7}$ (Scheme 127) involved the conversion of compound $\mathbf{3 8 4}$ to (Z)-4-aryl-5-benzylidene-3-chloro-2( $5 H$ )-furanone
386

387 (rubrolide L)
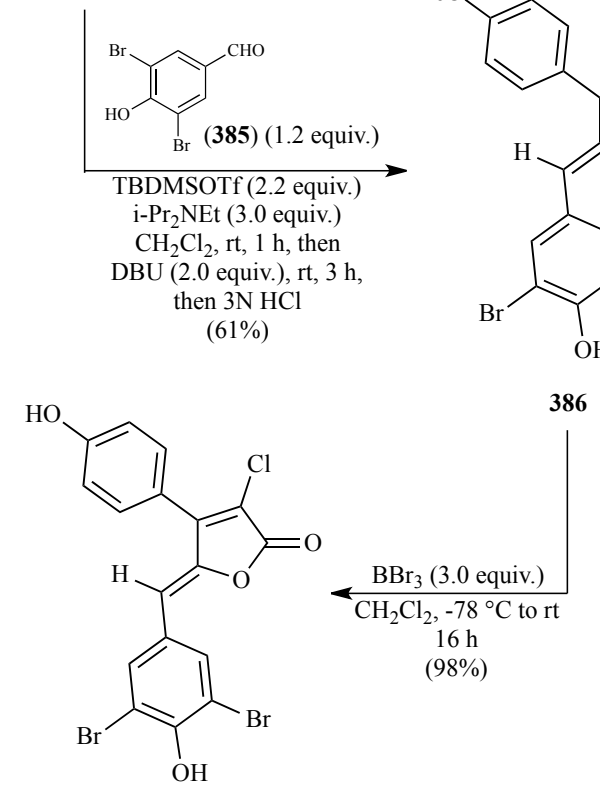

$(61 \%)$ 


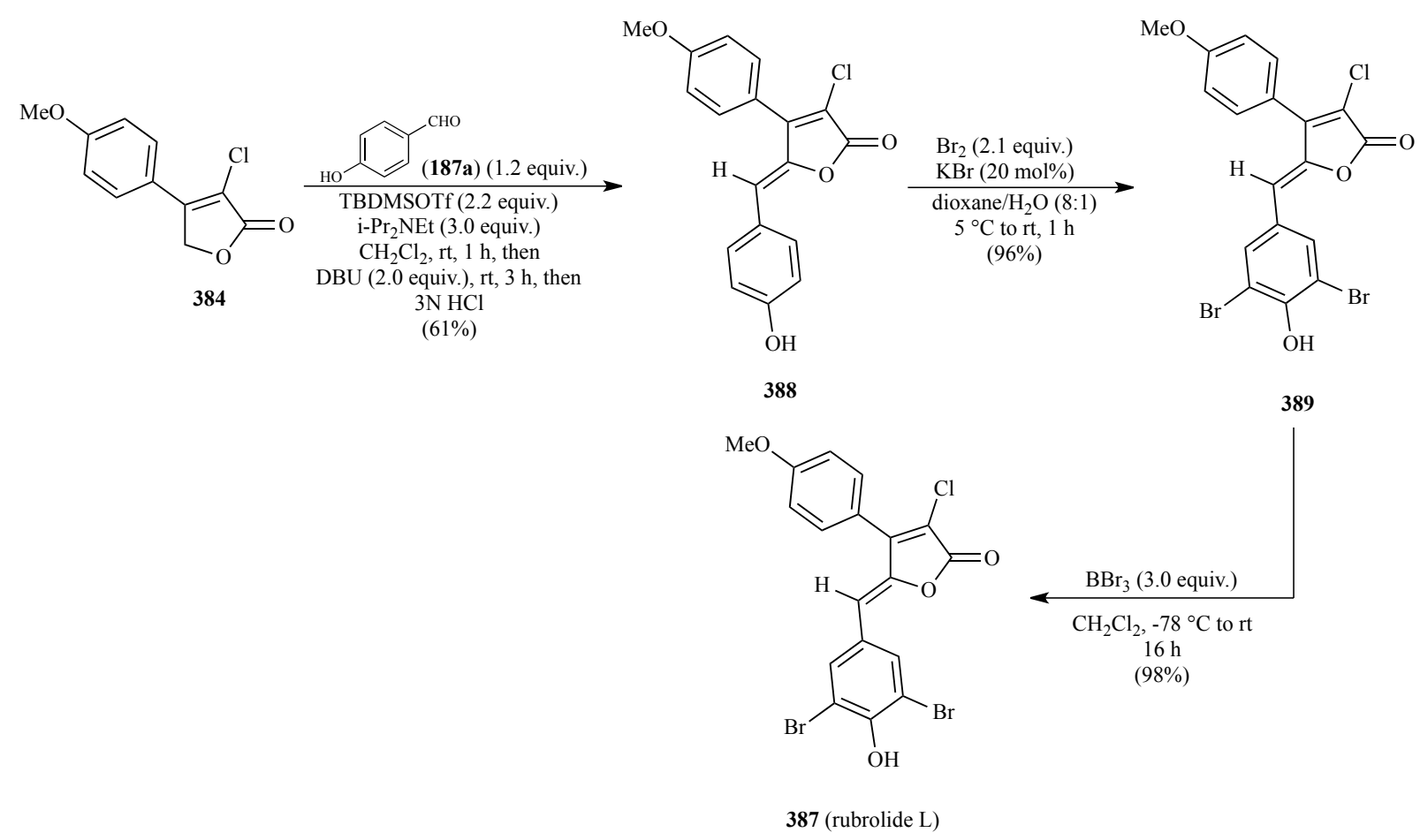

Scheme 127. Synthesis of rubrolide L (387) using compound $\mathbf{3 8 8}$ as an advanced intermediate

Bromination reaction of this compound using 2.0 equiv of bromine and $20 \mathrm{~mol} \% \mathrm{KBr}$ in a mixture of dioxane and water led to compound $\mathbf{3 8 9}$ in $96 \%$ yield. The synthesis of $\mathbf{3 8 7}$ was then completed in $95 \%$ yield by reacting $\mathbf{3 8 9}$ with 3 equiv of $\mathrm{BBr}_{3}$ in $\mathrm{CH}_{2} \mathrm{Cl}_{2}$ [218].

On the other hand, a $\operatorname{Pd}\left(\mathrm{PPh}_{3}\right)_{4} / \mathrm{CuI}$-catalyzed crosscoupling/lactonization reaction of (Z)-3-(4-acetoxy-3,5dibromophenyl)-3-iodoprop-2-enoic acid (390) with 1alkyne 372 was used in 1997 by Negishi and coworkers for the synthesis in $70 \%$ yield of rubrolide A diacetate (391) (Scheme 128) [216], the diacetyl derivative of a metabolite of the colonial tunicate Ritterella rubra [48] and the Australian ascidian Synoicum prunum [220].<smiles>CC(=O)Oc1c(Br)cc(/C(I)=C/C(=O)O)cc1Br</smiles>

390 (1.0 equiv.)<smiles>C#Cc1cc(Br)c(OC(C)=O)c(Br)c1</smiles>

372 (1.52 equiv.)<smiles>COc1c(Br)cc(/C=C2\OC(=O)C=C2c2cc(Br)c(OC(C)=O)c(Br)c2)cc1Br</smiles>

391

Scheme 128. Synthesis of rubrolide A diacetate (390)

Even naturally-occurring cadiolides A (359a), B (359b), C (359c) (Figure 22) and cadiolide D (359d) (Figure 23) have been the subject of several synthetic studies. 
<smiles>O=C1O/C(=C\c2ccc(O)c(Br)c2)C(c2cc(Br)c(O)c(Br)c2)=C1C(=O)c1cc(Br)c(O)c(Br)c1</smiles>

359d (cadiolide D)

Figure 27. Structure of cadiolide D

The first total synthesis of cadiolide B i.e. (Z)-3-(3,5dibromo-4-hydroxybenzoyl)-4-(3,5-dibromo-4-

hydroxyphenyl)-5-[(3,5-dibromo-4-

hydroxyphenyl)methylene]-2(5H)-furanone (359b) was carried out in 2005 by Boukouvalas and Poulet through the route outlined in Scheme 129 [221]. In particular, 4bromo-2 $(5 H)$-furanone (110) was converted to compound 393 by using an improved literature protocol [222] that involved the formation of a dibutylboron 2-furanolate by treatment of 110 with $n-\mathrm{Bu}_{2} \mathrm{BOTf}$ in the presence of 2,6lutidine and the subsequent in situ aldolization reaction with 4-methoxybenzaldehyde (91b). The $\mathrm{PdCl}_{2}(\mathrm{PhCN})_{2} / \mathrm{AsPh}_{3}$-catalyzed Suzuki-type cross-coupling reaction of 393 with boronic acid $\mathbf{3 0 2}$ in THF in the presence of $\mathrm{Ag}_{2} \mathrm{O}$ as the base gave alcohol 394, which was subsequently oxidized with Dess-Martin periodinane providing ketone 395 in high yield. Aldol reaction of 395 with aldehyde 91b in the presence of TBDMSOTf and $i$ $\mathrm{Pr}_{2} \mathrm{NEt}$, followed by in situ $\beta$-elimination with DBU gave stereoisomerically pure compound 396 in $94 \%$ yield. Next, compound 395 was fully $O$-demethylated by treatment with $\mathrm{BBr}_{3}$ in $\mathrm{CH}_{2} \mathrm{Cl}_{2}$ and the resulting compound 397 was brominated with bromine $/ \mathrm{KBr}$ providing cadiolide $\mathrm{B}$ (359b) in an excellent yield (Scheme 129) [221].

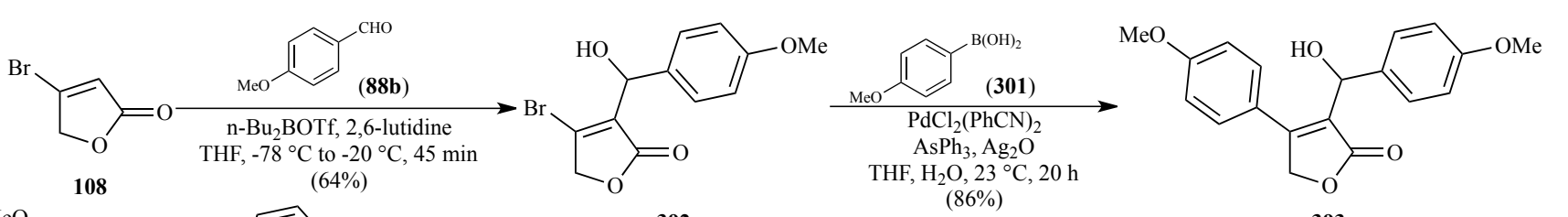<smiles>COc1ccc(/C=C2\OC(=O)C(C(=O)c3ccc(OC)cc3)=C2c2ccc(OC)cc2)cc1</smiles>

392 $(86 \%)$ 393

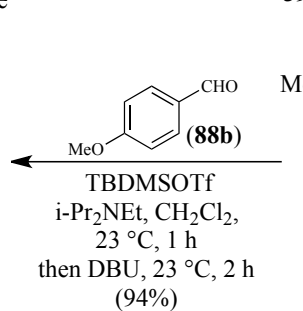<smiles>COc1ccc(C(=O)C2=C(c3ccc(OC)cc3)COC2=O)cc1</smiles>

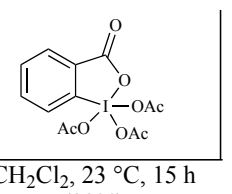
$(89 \%)$

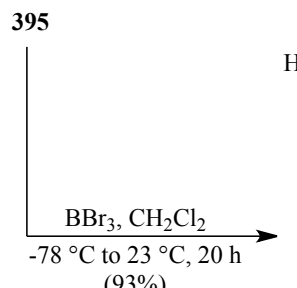
$(93 \%)$<smiles>O=C1O/C(=C\c2ccc(O)cc2)C(c2ccc(O)cc2)=C1C(=O)c1ccc(O)cc1</smiles>

396

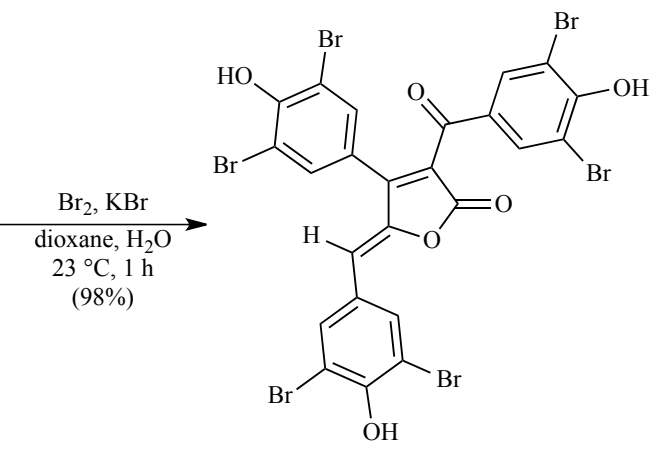

359b (cadiolide B)
Scheme 129. First total synthesis of cadiolide B (359b)

In 2013, Leleu, Franck and coworkers described another synthesis of cadiolide $\mathrm{B}$ in which (Z)-3-(4methoxybenzoyl)-5-(4-methoxybenzylidene)-4-(4methoxyphenyl)-2(5H)-furanone (399), which was used as an advanced intermediate, was obtained in $77 \%$ yield by reacting 1.0 equiv of $\alpha$-hydroxyketone 397 with 1.0 equiv of aldehyde $\mathbf{8 8 b}$ and 2.0 equiv of [6-(4-methoxyphenyl)2,3-dimethyl-4H-1,3-dioxin-4-one] (398) in toluene at 150 


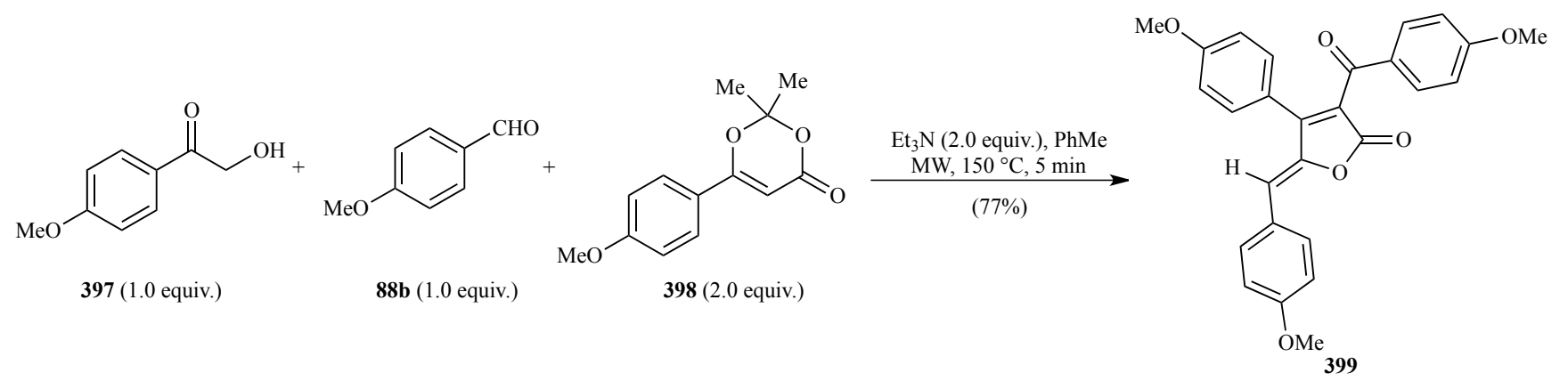<smiles>O=C1O/C(=C\c2cc(Br)c(O)c(Br)c2)C(c2cc(Br)c(O)c(Br)c2)=C1C(=O)c1cc(Br)c(O)c(Br)c1</smiles>

359b

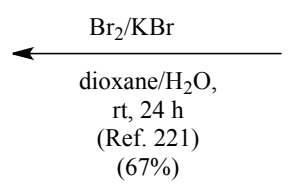<smiles>COc1ccc(/C=C2\OC(=O)C(C(=O)c3ccc(OC)cc3)=C2c2ccc(OC)cc2)cc1</smiles>

396

Scheme 130. Synthesis of cadiolide B (359b) via the microwave-promoted .

Compound 399 was converted into cadiolide B (359b) in $63 \%$ overall yield via a two-step route which was identical to that previously used by Boukouvalas and Poulet [221].

It deserves to be mentioned that, in 2014, that cadiolide B was found to exhibit antiviral activity against the Japanese encephalite virus at a concentration of $1 \mu \mathrm{g} / \mathrm{mL}$ [224].

More recently, Boukouvalas and Thibault reported the first synthesis of cadiolides A (359a) and D (359d) and a new synthesis of cadiolide B (359b) [225]. As outlined in Scheme 131, these compounds were synthesized by using the "click-unclick" Dield-Alder cycloaddition-cycloreversion of commercially available 5-ethoxy-4methyloxazole (403) with ynone 404. The latter compound was prepared in $96 \%$ yield by $\mathrm{PdCl}_{2}\left(\mathrm{PPh}_{3}\right)_{2} / \mathrm{CuI}$-catalyzed cross-coupling of commercially available 4methoxybenzoyl chloride (400) with 4methoxyphenylacetylene (401) in THF at room temperature in the presence of $\mathrm{Et}_{3} \mathrm{~N}$ as previously described 
<smiles>COc1ccc(C#CC(=O)c2ccc(OC)cc2)cc1</smiles><smiles>CCOC1(C)C(C)=NC2OC1C(c1ccc(OC)cc1)=C2C(=O)c1ccc(C)cc1</smiles><smiles>CCOc1occ(-c2ccc(OC)cc2)c1C(=O)c1ccc(OC)cc1</smiles><smiles>COc1ccc(C(=O)C2=C(c3ccc(OC)cc3)COC2=O)cc1</smiles>

405

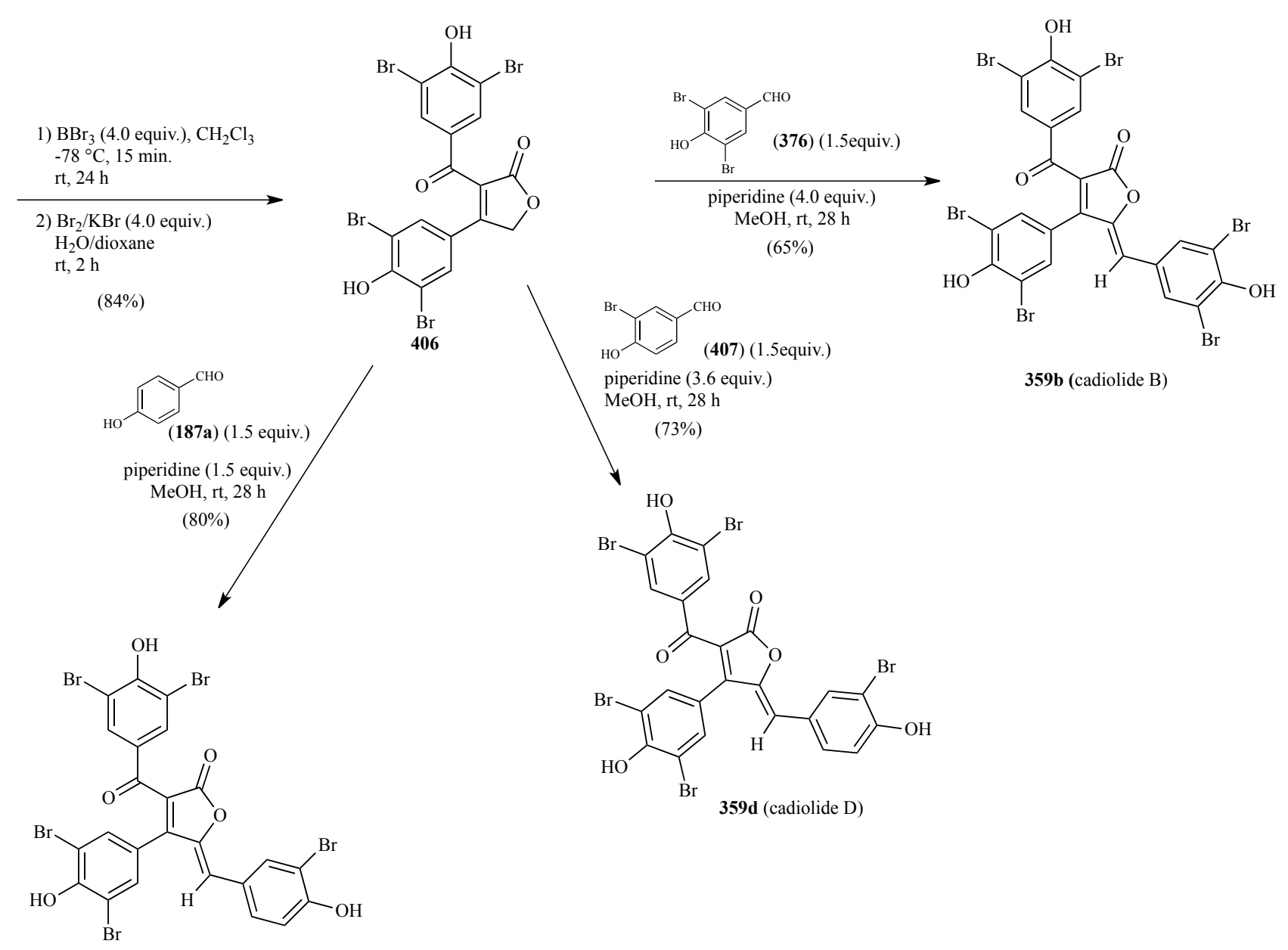

359a (cadiolide A)

Scheme 131. Stereoselective synthesis of cadiolides A (359a), B (359b) and D (359d) 
Crude compound 404, which was obtained from the reaction of $\mathbf{4 0 2}$ with $\mathbf{4 0 3}$, was treated with aqueous $\mathrm{HBr}$ in $\mathrm{THF}$ at room temperature providing 3-(4methoxybenzoyl)-4-(4-methoxyphenyl)-2(5H)-furanone (405) in 70\% yield. This compound was then treated with 4.0 equiv of $\mathrm{BBr}_{3}$ in $\mathrm{CH}_{2} \mathrm{Cl}_{2}$ at $-78{ }^{\circ} \mathrm{C}$ for $15 \mathrm{~min}$ and at room temperature for $24 \mathrm{~h}$ and the resulting crude product was reacted with a solution of 4 equiv of $\mathrm{KBr}_{3}$, which was prepared in situ from bromine and $\mathrm{KBr}[221,229]$ in water and dioxane at room temperature. In this way 3-(3,5dibromo-4-hydroxybenzoyl)-4-(3,5-dibromo-4-

hydroxyphenyl)-2(5H)-furanone (406) was obtained in $84 \%$ yield. This compound was used as an advanced precursor to cadiolides A, B and D. Thus, by using classical Knoevenagel conditions (piperidine as base, methanol as solvent, room temperature) compound $\mathbf{4 0 6}$ was reacted with 4-hydroxybenzaldehyde (187a), 3,5dibromo-4-hydroxybenzaldehyde (376) and 3-bromo-4- methoxybenzaldehyde (407) leading to stereoisomerically pure compounds 359a, 359b and 359d, respectively, in $80 \%, 65 \%$ and $73 \%$ yield, respectively (Scheme 131) [225].

Furthermore, in 2015, cadiolides C (359c) and A (359a) were synthesized by Franck and coworkers [213] by using the one-pot reaction of $\alpha$-hydroxyketones, dioxinones and aryl aldehydes, which they had previously employed in the synthesis of cadiolide B (359b) [223]. As shown in Scheme 132, cadiolide C (359c) was obtained in $47 \%$ yield by reacting 1.0 equiv of $\alpha$-hydroxyketone 359, 2.0 equiv of dioxinone 408 and 1.0 equiv of aldehyde 228 with 2.0 equiv of $\mathrm{Et}_{3} \mathrm{~N}$ in toluene under microwave irradiation at $150{ }^{\circ} \mathrm{C}$ for $5 \mathrm{~min}$ and treatment of the resulting reaction mixture with $1 \mathrm{M} \mathrm{HCl}$ followed by $\mathrm{BBr}_{3}$-mediated $O$ demethylation of the resulting product [230].<smiles>COc1ccc(C(=O)CO[C@H](C)O[Na])cc1C1=CC(=O)OC(C)(C)O1</smiles>

Scheme 132. One-pot multicomponent synthesis of cadiolide C (359c)

A similar protocol allowed Franck and coworkers to obtain cadiolide A (359a) in 18\% yield starting from $\alpha$ hydroxyketone 410, dioxinone 409 and aldehyde $\mathbf{8 8 b}$ (Scheme 133) [213].
Notably, cadiolide C appeared capable to inhibit the bacterial growth of Bacillus cereus (CECT 148), Salmonella typhi (CECT 409) and E. coli 405 with a MIC value of $3.90 \mu \mathrm{g} / \mathrm{mL}$ and cadiolide A required the same concentration of tetracycline to inhibit the bacterial growth of $S$. typhi and E. coli 405 with a MIC value of 8.81 $\mu \mathrm{g} / \mathrm{mL}$

[213]. 
<smiles>COc1c(Br)cc(C(=O)CO)cc1Br</smiles>

$\mathbf{4 1 0}$ (1.0 equiv.)<smiles>COc1c(Br)cc(C2=CC(=O)OC(C)(C)O2)cc1Br</smiles>

409 ( 2.0 equiv.)<smiles>COc1ccc(C=O)cc1</smiles>

$\mathbf{8 8 b}$ ( 1.0 equiv.)

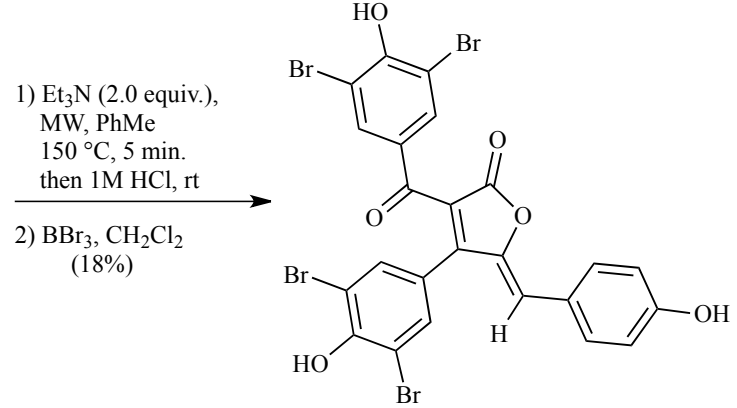

359a (cadiolide A)

Scheme 133. One-pot multicomponent synthesis of cadiolide A (359a)

Finally, in concluding this section, it is worth mentioning that, in 2013, Kutty, Kumar and coworkers designed, synthesized and evaluated some fimbrolide-nitric oxide donor hybrids as antimictrobial agents and found that 3-(1nitroxybutyl)-5-(dibromomethylene)-2( $5 H)$-furanone

(411a), 3-(1-nitroxydodecyl)-5-(dibromomethylene)2(5H)-furanone (411b) and 1-[5-(dibromomethylene)-2oxo-2,5-dihydrofuran-3-yl]butyl 2-(nitrooxy)acetate (412) (Figure 28) were particularly effective as antimicrobial compared to the nonhybrid naturally-occurring fimbrolides as revealed by Pseudomonas aeruginosa QS reporte assays and biofilm inbition assays [230].<smiles>[R]C([R])[O+]([O-])O[N+](=O)C1=CC(=C(Br)Br)OC1=O</smiles>

411a : $\mathrm{R}=n-\mathrm{C}_{3} \mathrm{H}_{7}$ 411b : $\mathrm{R}=n-\mathrm{C}_{11} \mathrm{H}_{23}$<smiles>CCCC(CC(=O)C[N+](=O)[O-])C1=CC(=C(Br)Br)OC1=O</smiles>

412

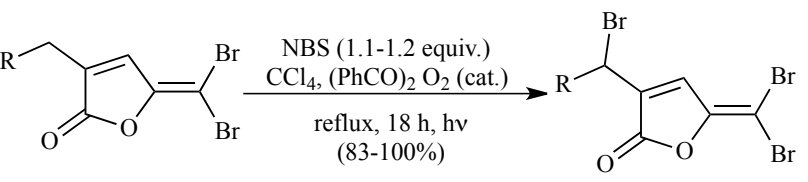

413<smiles>[R]C(C1=CC(=C(Br)Br)OC1=O)[N+](=O)[O-]</smiles>

411 (6 examples)

Scheme 134. Synthesis of fimbrolide-nitric oxide donor hybrids 411

Figure 28. Structures of compounds $412 \mathrm{a}, \mathrm{b}$ and 413

Compounds of general formula 411, including 411a and 411b, were synthesized in high yields from the corresponding fimbrolide analogues 413 (Scheme 134) [230], which in turn were prepared by sulfuric acidmediated cyclization of brominated 2-alkyllevulinic acids [103]. Allylic bromination of compounds 413 using NBS as the brominating reagent in the presence of benzoyl5peroxide gave compounds $\mathbf{4 1 3}$ in good to excellent yields, which were then converted to the corresponding nitrooxy-substituted fimbrolides 411 in 71$80 \%$ yield by treatment with $1.2-1.7$ equiv of $\mathrm{AgNO}_{3}$ in acetonitrile at $70{ }^{\circ} \mathrm{C}$. On the other hand, the fimbrolidenitrooxy derivative $\mathbf{4 1 2}$ was synthesized in $62.6 \%$ overall yield via the two-step reaction sequence shown in Scheme 135 [231]. 
<smiles>CCCC(O)C1=CC(=C(Br)Br)OC1=O</smiles><smiles>CCCC(OC(=O)CBr)C1=CC(=C(Br)Br)OC1=O</smiles><smiles>CCCC(CC(=O)CO[N+](=O)[O-])C1=CC(=C(Br)Br)OC1=O</smiles>

412

Scheme 135. Synthesis of compound 412

Specifically, 1.0 equiv of 3-(1-hydroxybutyl)-5(dibromomethylene)-2(5H)-furanone (416) was reacted with 1.5 equiv of bromoacetyl chloride (415) in $\mathrm{CH}_{2} \mathrm{Cl}_{2}$ providing compound $\mathbf{4 1 7}$ in $87 \%$ yield. The subsequent reaction of 417 with 1.5 equiv of $\mathrm{AgNO}_{3}$ in acetonitrile under reflux gave compound $\mathbf{4 1 2}$ in $72 \%$ yield. Compound 416 was in turn obtained in 59\% yield by treatment of bromofimbrolide 413a with water in DMS at room temperature for $72 \mathrm{~h}$ (Scheme 136) [230].

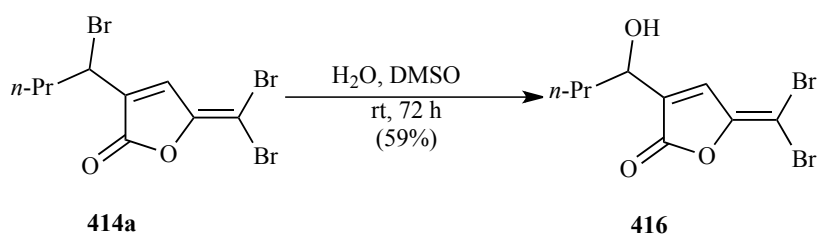

Scheme 136. Synthesis of compound $\mathbf{4 1 6}$

Notably, compounds $\mathbf{4 1 1}$ and $\mathbf{4 1 2}$ were proved capable to release in aqueous media nitric oxide [230], a compound which has been shown to influence biofilm dispersal in $P$. aeruginosa [231] and to control biofilm properties at picomolar to nanomolar concentrations [232]. It was also observed that the most potent and nonbactericidal compound in the biofilm inhibition assay was fimbrolide-
NO donor hybrid compound $\mathbf{4 1 1 b}$, which showed a $73 \%$ decrease in biofilm biomass [230]

\section{CONCLUSION}

In this article, we have attempted to give a comprehensive overview of the several methodologies and strategies that have been developed and used in the literature since 1951 up to the end of February 2016 for the synthesis of natural and unnatural 2(5H)-furanone derivatives bearing bromine atoms on the heterocyclic ring and/or brominated substituents. Attention has also been placed to describe, albeit in summary form, the biological properties of the synthesized compounds, including their mutagenic, enzymatic, anti-inflammatory photosynthetic inhibitory activity, turning however more attention to those derivatives that demonstrated to exhibit antimicrobial activity via inhibition of quorum sensing and biofilm fomation.

In fact, as outlined in the previous sections of this review, in recent years numerous studies have been made on the identification and synthesis of brominated 2(5H)furanone derivatives which, acting as QS inhibitors (also referred as quorum quenching (QQ) compounds, are able to fight bacterial pathogens, including those that have developed resistance to antibiotics by reducing their virulence and biofilm formation without affecting their growth. These studies have been largely justified by the fact that the approach involving the use of QQ compounds has been long considered less prone to cause resistance in bacterial populations than that based on the use of antibiotics [233-235], thereby producing significant benefits in areas such as human health, agricolture and industry.

Unfortunately, in recent years, these expectations have been at least partially questioned by the fact that results have been obtained showing that some bacterial strains such as Pseudomonas aeruginosa PAO1 and PA14 can manifest resistance to QS inhibitors and, among these, $(Z)$ 4-bromo-5-(bromomethylene)-2(5H)-furanone (C-30) (145) [236-238].

These data, however, do not prevent to suppose that it is possible to identify novel antimicrobial brominated $2(5 H)$ furanones that at appropriate concentrations are capable of controlling biofilm formation and virulence factors without the development of resistance. Moreover, it should be taken into account that a possible resistance to antibacterial brominated $2(5 H)$-furanone derivatives might be overcome by combining the administration of the antibacterial brominated furanones with that of efflux pump inhibitors $[239,240]$. 
We therefore believe that it is important to actively continue the studies on the synthesis and evaluation of the antimicrobial activity of brominated 2(5H)-furanone derivatives also including among these substances the following natural compounds for which synthetic methods have not yet been reported and the biological properties have not yet been evaluated: $(Z, Z)-5,5$ '-(1,2dibromoethanediylidene)-bis(4-bromo-3-butyl)]-2(5H)-

furanone (417) [142], pulchralides A (418), B (419) and C (420), acetoxyfimbrolide $\mathrm{C}_{2}$ dimer (421), acetoxyfimbrolide meso dimer (422) [241], cis-4,11,12,13tetrabromo-3,10-dibutyl-1,6,8-

trioxadispiro[4.1.4.2] trideca-3,10,12-triene-2,9-dione (423) [142], and prunolides A (424) and B (425) [220] (Figure 29].
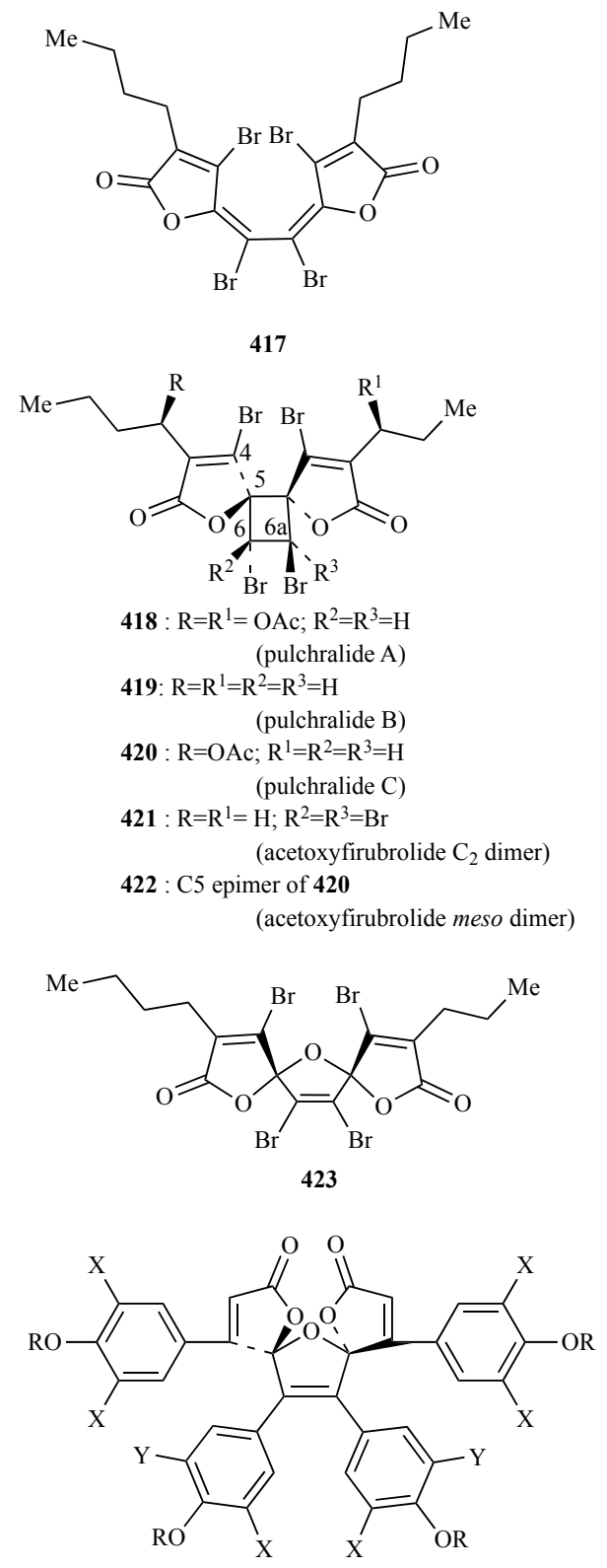

424: $\mathrm{R}=\mathrm{H} ; \mathrm{X}=\mathrm{Y}=\mathrm{Br}$ (prunolide $\mathrm{A}$ ) $425: \mathrm{R}=\mathrm{Y}=\mathrm{H} ; \mathrm{X}=\mathrm{Br}$ (prunolide $\mathrm{B}$ )
Figure 29. Structures of naturally-occurring compounds 419-427

It is also our hope that the chemical and biological data reported in this review can be of help in designing efficient and versatile methods for the synthesis of these natural compounds and new, tunable, unnatural brominated $2(5 H)$ furanone derivatives possessing interesting biological properties.

\section{LIST OF ABBREVIATIONS}

Ac $=$ acetyl

AHL $=N$-acyl homoserine lactone

AIBN $=2,2$ '-azobisisobutyronitrile

$\mathrm{Ar}=\operatorname{aryl}$

$\mathrm{BHL}=N$-butanoyl- $L$-homoserine lactone

$\mathrm{Bn}=$ benzyl

$\mathrm{Bu}=$ butyl

coll $=$ 2,4,6-trimethylpyridino

$\mathrm{Cp}=$ cyclopentadienyl

$\mathrm{Cy}=$ cyclohexyl

$\mathrm{d}=$ day

$\mathrm{dba}=$ dibenzoylacetone

$\mathrm{DBU}=1,5$-diazabicycloundec-7-ene

DIBAH $=$ diisopropylaluminum hydride

$\mathrm{DMF}=N, N$-dimethylformamide

DMSO $=$ dimethyl sulfoxide

$\mathrm{Et}=$ ethyl

Hept $=$ heptyl

Hex $=$ hexyl

HMPA = hexamethylphosphoramide

$\mathrm{IC}_{50}=$ half maximal inhibitory concentration

LDA = lithium diisopropylamide

MCPBA $=m$-chloroperbenzoic acid

$\mathrm{Me}=$ methyl

$\mathrm{MIC}=$ minimum inhibitory concentration

MMPP = magnesium monoperoxyphthalate

$\mathrm{MW}=$ microwave

$\mathrm{NAPDH}=$ nicotinamide adenine dinucleotide phosphate

$\mathrm{NBS}=N$-bromosuccinimide

$\mathrm{NMP}=N$-methyl-2-pyrrolidone

Oct $=$ octyl

$\mathrm{PCC}=$ pyridinium chlorochromate

$\mathrm{PDC}=$ pyridinium dichromate

Pent $=$ pentyl

$\mathrm{Ph}=$ phenyl

$\operatorname{Pr}=$ propyl

$\mathrm{QQ}=$ quorum quenching

$\mathrm{QS}=$ quorum sensing

$\mathrm{rt}=$ room temperature

TBDMS = tert-butyldimethtylsilyl

TFA $=$ trifluoroacetic acid

$\mathrm{TFE}=$ 2,2,2-trifluoroethanol

$\mathrm{THF}=$ tetrahydrofurane

TLC $=$ tin-layer chromatography 
TMS = trimethylsilyl

Tol $=$ tolyl

$p$-Ts $=p$-toluenesulfonyl

\section{CONFLICT OF INTEREST}

The authors confirm that this article conent has no conflict of Interest.

\section{REFERENCES}

[1] Rao, Y. S. Recent advances in the chemistry of unsaturated lactones. Chem. Rev. 1976, 76, 625-694.

[2] Avetisyan, A. A.; Dangyan, M. T. The chemistry of $\Delta^{\alpha, \beta}$. butenolides. Russ. Chem. Rev. 1977, 46, 643-655.

[3] Pattenden, G. Natural 4-ylidenebutenolides and 4ylidenetetronic acids. Progr. Chem. Org. Nat. Prod. 1978, 35, 133-198.

[4] Knight, D. W. Synthentic apporaches to butenolides. Contemp. Org. Synth. 1994, 1, 287-315.

[5] Negishi, E.-i.; Kotora, M. Regio- and stereoselective synthesis of $\gamma$-alkylidenebutenolides and related compounds. Tetrahedron 1997, 53, 6707-6738.

[6] Brückner, R. The $\beta$-elimination route to $\gamma$ alkylidenebutenolides. Chem.Commun. 2001, 141-152.

[7] Brückner, R. The synthesis of $\gamma$-alkylidenebutenolides. Curr. Org. Chem. 2001, 5, 679-718.

[8] Rossi, R.; Bellina, F. Recent advances in the regio- and stereocontrolled synthesis of natural and unnatural stereodefined 5-ylidene-2(5H)-furanones. Targets in Heterocyclic Systems 2001, 5, 169-198.

[9] Carter, N. B.; Nadany, A. E.; Sweeney, J. B. Recent developments in the synthesis of furan-2 $(5 H)$-ones. $J$. Chem. Soc., Perkin Trans. 1 2002, 2324-2342.

[10] Bellina, F.; Rossi, R. Mucochloric and mucobromic acids: inexpensive, highly functionalized starting materilas for the selective synthesis of variously substituted 2(5H)-furanone derivatives, sulfur- or nitrogen-containing heterocycles and stereodefined acyclic unsaturated dihalogenated compounds. Curr. Org. Chem. 2004, 8, 1089-1103.

[11] De Souza, M. V. N. The furan-2(5H)-ones: recent synthetic methodologies and its application in total synthesis of natural products. Mini-Rev. Org. Chem. 2005, 2, 139-145.

[12] De Nys, R.; Givskov, M.; Kumar, N.; Kjelleberg, S.; Steinberg, P. D. Furanones. Prog. Mol. Subcell. Biol. 2006, 42, 55-86.

[13] Ugurchieva, T. M.; Veselovsky, V. V. Advances in the synthesis of natural butano- and butenolides. Russ. Chem. Rev. 2009, 78, 337-373.4

[14] Cunha, S.; Oliveira, C. C. Aplicaçöes sintéticas do ácido mucobrômico e da 3,4-dibromofuran-2(5H)-ona. Quim. Nova 2011, 34, 1425-1438.
[15] Yan, L.; Wu, X.; Liu, H.; Xie, L.; Jiang, Z. Catalytic asymmetric synthesis of $\gamma$-butenolides by direct vinylogous reactions. Mini Rev. Med. Chem. 2013, 845853.

[16] Zhang, Q.; Liu, X.; Feng, X. Recent advances in enantioselective synthesis of $\gamma$-substituted butenolides via the catalytic asymmetric vinylogous reactions. Curr. Org. Synth. 2013, 10, 764-785.

[17] Miles, W. H. Synthetic applications of $\gamma$ hydroxybutenolides. Curr. Org. Synth. 2014, 11, 244287.

[18] Jusseaux, X., Chabaud, L.; Guillou, C. Synthesis of $\gamma-$ butenolides and $\alpha, \beta$-unsaturated $\gamma$-butyrolactams by addition of vinylogous nucleophiles to Michael acceptors. Tetrahedron 2014, 70, 2595-2615.

[19] LaSarre B.; Dederle, M. J. Exploiting quorun sensing to confuse bacterial pathogens. Microbiol. Mol. Biol. Rev. 2013, 77, 73-111.

[20] Worthington, R. J.; Richards, J. J.; Melander, C. Small molecule control of bacterial biofilms. Org. Biomol. Chem. 2012, 10, 7457-7474.

[21] Wu, H.; Song, Z.; Hentzer, M.; Andersen, J. B.; Molin, S.; Givskov, M.; Høiby, N. Synthetic furanones inhibit quorum sensing and enhance bacterial clearance in Pseudomonas aeruginosa lung infection in mice. $J$. Antimicrob. Chemother. 2004, 53, 1054-1061.

[22] For leading references, see: (a) Kjelleberg, S.; Steinberg, P.; Givskov, M.; Gram, L.; Manefield, M.; de Nys, R. Do marine natural products interfere with prokariotic AHL regulatory systems? Aquat. Microbiol. Ecol. 1997, 13, 85-93; (b) Kearns, D. B. A field guide to bacterial swarming motility. Nat. Rev. Microbiol. 2010, 8, 634644; (c) Butler, M. T.; Wang, Q.; Harshey, R. M. Cell density and mobility protect swarming bacteria against antibiotics. PNAS 2010, 107, 3776-3781; (d) Rutherford, S. T.; Bassler, B. L. Bacterial quorum sensing: its role in virulence and possibilities for its control. Cold Spring Harbor Perspect. Med. 2012; 2:a012427.

[23] Defoirdt, T.; Crab, R.; Wood, T. K.; Sorgeloos, P.; Verstraete, W.; Bossier P. Quorum sensing-disrupting brominated furanones protect the gnotobiotic brine shrimp Artemia franciscana from pathogenic Vibrio harveyi, Vibrio campbellii, and Vibrio parahaemolyticus isolates. Appl. Environ. Microbiol. 2006, 72, 6419-6423.

[24] Janssens, J. C. A.; Steenackers, H.; Robijns, S.; Gellens, E.; Levin, J.; Zhao, H.; Hermans, K.; De Coster, D.; Verhoeven, T. L.; Marchal, V.; Vanderleyden, J.; De Vos, D. E.; De Keersmaecker, S. C. J. Brominated furanones inhibit biofilm formation by Salmonella enterica Serovar Thyphimurium. Appl. Environ. Microbiol. 2008, 74, 6639-6648.

[25] Yang, S.; Abdel-Razek, O. A.; Cheng, F.; Bandyopadhyay, D.; Shetye, G. S.; Wang, G.; Luk, Y.Y. Bicyclic brominated furanones- a new class of quorum sensing modulators that inhibit bacterial biofilm formation. Bioorg. Med. Chem. 2014, 22, 1313-1317. 
[26] (a) Lade, H.; Paul, D.; Kweon, J. H. Quorum quenching mediated approaches for control of membrane biofouling. Int. J. Biol. Sci. 2014. 10. 550-565; (b) Kayumov, A. R.; Khakimullina, E. N.; Sharafutdinov, I. S.; Trizna, E. Y.; Latypova, L. Z.; Lien, H. T.; Margulis, A. B.; Bogachev, M. I.; Kurbangalieva, A. R. Inhibition of biofilm fomation in Bacillus subtilis by new halogenated furanones. J. Antibiot. 2015, 68, 297-301; (c) Rabin, N.; Zheng, Y.; Opoku-Temeng, C.; Du, Y.; Bonsu, E.; Sintim, H. O. Agents that inhibit bacterial biofilm formation. Future Med. Chem. 2015, 7, 647671.

[27] Reffstrup, T.; Boll, P. M. Synthesis of narthogenin, the aglycon of narthecide. Phytochemistry 1979, 18, 325326.

[28] Starbursvik, A. Isolation of $\alpha$-methoxy- $\Delta^{\alpha, \beta}$-butenolide from Narthecium ossifragrum (L.) Huds. Acta Chem. Scand. 1954, 8, 525.

[29] Song, Y. S.; Lee, Y.-J.; Kim, B. T.; Heo, J.-N. An efficient procedure for the synthesis of 3-aryl-4methoxy-2 $(5 H)$-furanones by using the microwavepromoted Suzuki-Miyaura coupling reactions. Tetrahedron Lett. 2006, 47, 7427-7430.

[30] Kowalski, C. J.; Weber, A. E.; Fields, K. W. $\alpha$-Keto dianion precursors via conjugate addition to cyclic $\alpha$ bromoenones. J. Org. Chem. 1982. 47, 5088-5093.

[31] Vasamsetty, L.; Khan, F. A.; Mehta, G. Total synthesis of a novel oxa-bowl natural product paracaseolide A via a putative biomimetic pathway. Tetrahedron Lett. 2013, $54,3522-3525$.

[32] Feringa, B. L.; De Lange, B. Asymmetric 1,4-additions to 5-alkoxy-2(5H)-furanones. An efficient synthesis of $(R)$ - and (S)-3,4-epoxy-1-butanol. Tetrahedron 1988, 44, 7213-7222.

[33] Pei, Q.; Sun, J.-Y.; Jin, C.-X.; Niu, M.-L.; Huang, K.-J. Synthesis, stereochemistry and anticancer activity of 6. $\mathrm{N}$-alkyl-4-methoxy-3-oxa-6-azabicyclo[3.1.0]hexan-2one. Chin. J. Org. Chem. 2010, 30, 698-702.

[34] Cheng, Y.; Ding, W.-h.; Long, Q.; Zhao, M.; Yang, J.; $\mathrm{Li}, \mathrm{X}$. -q. Synthesis of stable isotopically labelled 4methylfuran-2 $(5 H)$-one and the corresponding strigolactones. J. Label Compd. Radiopharm. 2015, 58, 355-360.

[35] De Echagüen, C. O.; Ortuño, R. M. The Bromination of $\beta$-angelica lactone revisited: synthesis of new 3.bromo5-methylene- and 3-bromo-5-methyl-2( $5 H)$-furanones. Tetrahedron 1994, 50, 12457-12462.

[36] Font. J.; Sánchez-Ferrando, F.; Segura, C.; Piniella, J. F.; Jeffrey, G. A.; Ruble, J. R. Studies on structurally simple $\alpha, \beta$-butenolides VIII. 5-Haloalkyl- and 3-bromo-5hydroxyalkyl-2(5H)-furanones. J. Heterocyclic Chem. 1990, 27, 183-187.

[37] Aquino, M.; Bruno, I.; Riccio, R.; Gomez-Paloma, L. Regioselective entry to bromo- $\gamma$-hydroxybutenolides: useful building blocks for assembling natural productlike libraries. Org. Lett. 2006, 8, 4831•4834.
[38] Boukouvalas, J.; Loach, R. P. General regiodefined access to $\alpha$-substituted butenolides through metalhalogen exchange of 3-bromo-2-silyloxyfurans. Efficient synthesis of an anti-inflammatory gorgonian lipid. $J$. Org. Chem. 2008, 73, 8109-8112.

[39] Movassaghi, M.; Jacobsen, E. N. A direct method for the conversion of terminal epoxides to $\gamma$-butenolides. $J$. Am. Chem. Soc. 2002, 124, 2456-2457.

[40] Sorg, A.; Blank, F.; Brückner, R. Stepwise crosscoupling of a dibromo- $\gamma$-methylenebutenolide as an access to $Z$-configured $\alpha$-alkenyl- $\gamma$ alkylidenebutenolides. Straightforward synthesis of the antibiotic lissoclinolide. Synlett 2005, 1286-1290.

[41] Mathews, C. J.; Taylor, J.; Tyte, M. J.; Worthington, P. A. Microwave assisted Suzuki reactions for the preparation of the antifungal 3-aryl-5-methyl-2,5dihydrofuran-2-ones. Synlett 2005, 538-540.

[42] Ube, H.; Shimada, N.; Terada, M. Asymmetric direct vinylogous aldol reaction of furanone derivatives catalyzed by an axially chiral guanidine base. Angew. Chem. Int. Ed. 2010, 49, 1858-1861.

[43] Rossi, R.; Bellina, F.; Raugei, E. Selective synthesis of unsymmetrical 3,4-disubstituted and 4-substituted 2(5H)-furanones. Synlett 2000, 1749-1752.

[44] Ma, S.-M.; Shi, Z.-J. Synthesis of 4-halo-2(5H)furanones and their Suzuki coupling reactions with organoboronic acids. A general route to 4-aryl-2 $(5 H)$ furanones. Chin. J. Chem. 2001, 19, 1280-1284.

[45] Thombare, P.; Desai, J.; Argade, A.; Gite, S.; Shah, K.; Pavase, L.; Patel, P. Novel and efficient route for the synthesis of 4-aryl-substituted 2(5H)-furanones. Synth. Commun. 2009, 39, 2423-2429.

[46] Knochel, P.; Ye, M. C. P.; Berk, S. C.; Talbert, J. Synthesis and reactivity toward acyl chlorides and enones of the new highly functionalized copper reagent RCu(CN)ZnI. J. Org.Chem. 1988, 53, 2390-2392.

[47] Boukouvalas, J.; Lachance, N.; Ouellet, M.; Trudeau, M. Facile access to 4 -aryl-2( $5 H)$-furanones by Suzuki cross-coupling: efficient synthesis of rubrolides $\mathrm{C}$ and $\mathrm{E}$. Tetrahedron Lett. 1998, 39, 7665-7668.

[48] Miao, S.; Andersen, R. J. Rubrolides A-H, metabolites of the colonial tunicate Ritterella rubra. J. Org. Chem. 1991, 56, 6275-6280.

[49] Ortega, M. J.; Zubía, E.; Ocaña, J. M.; Naranjo, S.; Salvá, J. New rubrolides from the ascidian Synoicum blochmanni. Tetrahedron 2000, 56, 3963-3967.

[50] Bellina, F.; Anselmi, C.; Rossi, R. Synthesis of 4-alkyl3-bromo-2 $(5 H)$-furanones and unsymmetrically disubstituted 3,4-dialkyl-2( $5 H)$-furanones by palladiumcatalyzed cross-coupling reactions. Tetrahedron Lett. 2001, 42, 3851-3854.

[51] Yang, X.; Shimizu, Y.; Steiner, J. R.; Clardy, J. Nostoclides I and II, extracellular metabolites from a symbiotic cyanobacterium Nostoc sp. from the lichen Peltigera canina. Tetrahedron Lett. 1993, 34, 761-764. 
[52] Bellina, F.; Rossi, R. Synthetic applications of 3,4dihalo-2 $(5 H)$-furanones: a formal synthesis of nostoclides I and II. Synthesis 2002, 2729-2732.

[53] Zhang, J.; Blazecka, P. G.; Belmont, D.; Davidson, J. G. Reinvestigation of mucohalic acids, versatile and useful building blocks for highly functionalized $\alpha, \beta-$ unsaturated $\gamma$-butyrolactones. Org. Lett. 2002, 4, 45594561.

[54] Pereira, U. A.; Barbosa, L. C. A.; Maltha, C. R. A.; Demuner, A. J.; Masood, M. A.; Pimenta, A. L. Inhibition of Enterococcus faecalis biofilm formation by highly active lactones and lactams analogues of rubrolides. Eur. J. Med. Chem. 2014, 82, 127-138.

[55] Shi, J.; Tang, X.-D.; Wu, Y.-C.; Li, H.-N.; Song, L.-J.; Wang, Z.-Y. Palladium-catalyzed desulfitative arylation of 5-alkoxy-3,4-dibromo-2(5H)-furanone with sodium arylsulfinates. Eur. J. Org. Chem. 2015, 1193-1197.

[56] Lei, M.; Gan, X.; Zhao, K.; Chen, A.; Hu, L. Synthesis of 3,4-disubstituted furan-2(5H)-one derivatives by Suzuki-Miyaura reaction. Tetrahedron 2015, 71, 33253332.

[57] Yang, C.-T.; Zhang, Z.-Q.; tajuddin, H.; Wu, C.-C.; Liang, J.; Liu, J.-H.; Czyzewska, M.; Steel, P. G.; Marder, T. B.; Liu, L. Alkylboronic esters from coppercatalyzed borylation of primary and secondary alkyl halides and pseudohalides. Angew. Chem. Int. Ed. 2012, 51, 528-532.

[58] Clark, B.; Capon, R. J.; Tennant, S.; Gill, J. H.; Bulheller, B.; Bringmann, G. Gymnoascolides A-C: aromatic butenolides from an Australian isolate of the soil ascomycete Gymnoascus reessii. J. Nat. Prod. 2005, 68, 1226-1230.

[59] Lin, Y.; Li, H.; Jiang, G.; Zhou, S.; Vrijmoed, L. L. P.; Jones, E. B. G. A novel $\gamma$-lactone, eutypoid A and other metabolites from marine fungis Eutypa $\mathrm{sp} .(\neq 424)$ from the South China sea. Indian J. Chem. 2002, 41B, 15421544.

[60] Kimura, T.; Fukuda, K.; Kashiwamura, G.; Satoh, T. Synthesis of $\alpha$-halobutenolides using the nucleophilicity of magnesium alkylidene carbenoids. Heterocycles 2015, 90, 163-171.

[61] Zhang, R.; Chan, D.; Jessica, S.; Iskander, G.; Stc Black, $\mathrm{D}$; Kumar, N. Synthesis of new aryl substituted 5alkylidenefuran-2(5H)-ones. ARKIVOC 2009, 102-115.

[62] Chen, Q.; Geng, Z.; Huang, B. Synthesis of enantiomerically pure 5-(l-menthyloxy)-3,4-dibromo$2(5 H)$-furanone and its tandem asymmetric Michael addition-elimination reaction. Tetrahedron:Asymmetry 1995, 6, 401-404.

[63] Huang, H.; Chen, Q. Synthesis of enantiomerically pure spirocyclopropane derivatives containing multichiral centers. Tetrahedron: Asymmetry 1998, 9, 4103-4107.

[64] Wei, M.-X.; Feng, L.; Li, X.-Q.; Zhou, X.-Z.; Shao, Z.H. Synthesis of new chiral 2,5-disubstituted 1,3,4thiadiazoles possessing $\gamma$-butenolide moiety and preliminary evaluation of in vitro anticancer activity. Eur. J. Med. Chem. 2009, 44, 3340-3344.

[65] Van Oeveren, A.; Jansen, J. F. G. A.; Feringa, B. L. Enantioselective synthesis of natural dibenzylbutyrolactone lignans (-)-enterolactone, (-)hinokinin, (-)-pluviatolide, (-)-enterodiol, and furan lignan (-)-eudesmin via tandem conjugate addition to gamma-alkoxybutenolides. J. Org. Chem. 1994, 59, 5999-6007.

[66] Wei, M.-X.; Gao, X.-H.; Li, T.-C.; Fan, C.-A.; Li, X.-Q. Transalkylation of $\mathrm{N}$-methyl tertiary amines with 3,4dibromobutenolides. Chin. Chem. Lett. 2013, 24, 837839.

[67] Cunha, S.; Oliveira, C. C.; Sabino, J. R. Synthesis of 3bromotetronamides via amination of 3,4-dibromofuran2(5H)-one. J. Braz. Chem. Soc. 2011, 22, 598-603.

[68] Mo, Y.-Q.; Wang, Z.-Y.; Mei, W.-J.; Fu, J.-H.; Tan, Y.H.; Luo, S.-H. Reaction of 5-alkoxy-3,4-dihalo-2 $(5 H)$ furanones with secondary amines: expected versus unexpected products and their preliminary biological investigation. Monatsh. Chem. 2012, 143, 443-453.

[69] Rossi, R.; Bellina, F.; Mannina, L. A novel protocol for the stereoselective synthesis of variously substituted $(Z)$ 5-ylidene-5H-furan-2-ones. Tetrahedron Lett. 1998, 39, 3017-3020.

[70] Bellina, F.; Carpita, A.; De Santis, M.; Rossi, R. Highly regioselective palladium-mediated synthesis of stereoisomerically pure (Z)- and (E)-alkyl 2.bromo-3(hetero)arylpropenoates. Tetrahedron Lett. 1994, 35, 6913-6916.

[71] Rossi, R.; Bellina, F.; Bechini, C.; Mannina, L.; Vergamini, P. Studies on the transition metal-catalyzed synthesis of variously substituted (E)-3[1(aryl)methylidene)]- and (E)-3-(1-alkylidene)-3Hfuran-2-ones. Tetrahedron 1998, 54, 135-156.

[72] Rossi, R.; Bellina, F.; Carpita, A.; Mazzarella, F. Palladium-mediated cross-coupling reactions involving 3-substituted alkyl (E)-2,3-dibromopropenoates and arylziinc or aryltin derivatives. Tetrahedron 1996, 52, 4095-4110.

[73] Lardelli, G.; Dijstra, G.; Harkes, P. D.; Boldingh, J. New $\gamma$-lactones found in butter. Rec. Trav. Chim. Pays Bas 1966, 85, 43-55.

[74] Bellina, F.; Anselmi, C.; Viel, S.; Mannina, L.; Rossi, R. Selective synthesis of (Z)-4-aryl-5-[1(arylmethylidene)]-3-bromo-2(5H)-furanones. Tetrahedron 2001, 57, 9997-10007.

[75] Barbosa, L. C. A.; Maltha, C. R. A.; Lage, M. R.; Barcelos, R. C.; Donà, A.; Carneiro, J. W. M.; Forlani, G. Synthesis of rubrolide analogues as new inhibitors of the photosynthetic alectron transport chain. J. Agr. Food Chem. 2012, 60, 10555-10563.

[76] Pereira, U. A.; Barbosa, L. C. A.; Demuner, A. J.; Silva, A. A.; Bertazzini, M.; Forlani, G. Rubrolides as model for the development of new lactones and their aza 
analogs as potential photosynthesis inhibitors. Chem. Biodiv. 2015, 12, 987-1005.

[77] Clendenning, K. A. Biochemistry of chloroplasts in relation to the Hill reaction. Annu. Rev. Plant Physiol. 1957, 8, 137-151.

[78] Ngi, S. I.; Petrignet, J.; Duwald, R.; El Hilali, E. M.; Abarbri, M.; Duchêne, A.; Thibonnet, J. Coppercatalyzed domino route to natural nostoclides and analogues: a total synthesis of nostoclides I and II. $A d v$. Synth. Catal. 2013, 355, 2936-2941.

[79] Langle, S.; Ngi, S. I.; Anselmi, E.; Abarbri, M.; Thibonnet, J.; Duchêne, A. Selective synthesis of dihalosubstituted unsaturated carboxylic acids and derivatives. Synthesis 2007, 1724-1728.

[80] Varejão, J. O. S.; Barbosa, L. C. A.; Ramos, G. A.; Varejão, E. V. V.; King-Díaz, B.; Lotina-Hennsen, B. New rubrolide analogues as inhibitors of photosynthesis light reactions. J. Photochem. Photobiol. B 2015, 145, $11-18$.

[81] Andersen, R. J.; Burgoyne, D. L.; Williams, D. E.; Kong, F.; da Silva, E. D.; Miao, S.; Allen, T.; Holmes, C. F. B.; Chen, D.; Kent, M. New natural products from marine invertebrates. Gazz. Chim. Ital. 1993, 123, 293299.

[82] Chopin, N.; Yanai, H.; Iikawa, S.; Pilet, G.; Bouillon, J.P; Médebielle, M. A rapid entry to diverse $\gamma$ ylidenetetronate derivatives through regioselective bromination of tetronic acid derived $\gamma$-lactones and metal-catalyzed postfunctionalization. Eur. J. Org. Chem. 2015, 6259-6269.

[83] Schenk, G. O. Photochemische reaktionen III: Über die unsesibilisierte und photosenssibilisierte autoxidation von furanen. Justus Liebigs Ann. Chem. 1953, 584, 156176.

[84] Alguacil, R.; Fariña, F.; Martin, M. V. !,3-Dipolar cycloaddition of nitrile oxides to $2(5 H)$-furanones substituted at the 5 position by sulfur bearing groups. Tetrahedron 1996, 52, 3457-3472.

[85] Mabry, T. J. $\beta$-Bromocrotonolactone from the bromination of furoic acid. J. Org. Chem. 1963, 28, 1699-1700.

[86] Jas, G. Ein einfacher zugang zu 4-brom-2-(tertbutyldimethylsilyloxy)furan aus tetrahydro-2,4dioxofuran. Synthesis 1991, 965-966.

[87] Svendsen, J. S.; Sydnes, L. K. Selective formation of 4bromo-3-methyl-2(5H)-furanone by solvolysis of 2,2dibromo-1-methylcyclopropanecarboxylic acid. Acta Chem. Scand. 1990, 44, 202-204.

[88] Font, J.; Gracia, A.; de March, P. Synthesis of 5-alkyl-4bromo-5-hydroxy-2(5H)-furanones and 5-alkylidene-4bromo-2 $(5 H)$-furanones. Tetrahedron Lett. 1990, 31, $5517-5520$.

[89] Sydnes, L. K.; Mungaroo, R.; Aanesen, B. A. Silver ionassisted solvolysis of trans-2,2-dibromo-1,3dimethylcyclopropanecarboxylic acid: selective formation of 4-bromo-3,5-dimethyl-2(5H)-furanone. Acta Chem. Scand. 1998, 52, 1386-1391.

[90] Ma, S.; Shi, Z.; Yu, Z. Synthesis of $\beta$-halobutenolides

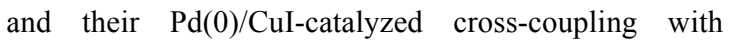
terminal alkynes. A general route to $\beta-(1$ 'alkynyl)butenolides. Tetrahedron Lett. 1999, 40, 23932396.

[91] Ma, S.; Shi, Z.; Yu, Z. Synthesis of $\beta$-halobutenolides and their $\operatorname{Pd}(0)$-catalyzed cross-coupling reactions with terminal alkynes and organozinc reagents. A general route to $\beta$-substituted butenolides and formal synthesis of cis-whisky lactone. Tetrahedron 1999, 55, 1213712148.

[92] Ma, S.; Wu, S. CuX ${ }_{2}$-mediated cyclization reaction of 2,3-allenoic acids. An efficient route to $\beta$ halobutenolides. J. Org. Chem. 1999, 64, 9314-9317.

[93] Ma, S.-M.; Shi, Z.-J. Synthesis of 4-halo-2(5H)furanones and their Suzuki reactions with organoboronic acids. A general route to 4-aryl-2(5H)-furanones. Chin. J. Chem. 2001, 19, 1280-1284.

[94] Ma, S.; Wu, S. $\mathrm{CuBr}_{2}$-mediated direct aqueous bromolactonization of 2,3-allenoates. An efficient access to $\beta$-bromobutenolides. Tetrahedron Lett. 2001, 42, 4075-4077.

[95] Ma, S.; Wu, B.; Shi, Z. An efficient synthesis of 4-halo5-hydroxy-furan-2 $(5 H)$-ones via sequential halolactonization and $\gamma$-hydroxylation of 4-aryl-2,3alkadienoic acids. halolactonization and $\gamma$-hydroxylation of 4-aryl-2,3-alkadienoic acids. J. Org. Chem. 2004, 69, $1429-1431$.

[96] Arayarat, P.; Singh, H.; Lattmann, E. Solid phase synthesis of substituted 4-amino-5-hydroxy-2 $(5 H)$ furanones. Science Asia 2001, 27121-125.

[97] Ohta, K. Antimicrobial compounds in the marine red alga Beckerella subcostatum. Agric. Biol. Chem. 1977, 41, 2105-2106.

[98] Jefford, C. W.; Jaggi, D.; Boukouvalas, J. Total synthesis of bromobeckerelide. Tetrahedron Lett. 1989, 30, 1237-1240.

[99] Jefford, C. W. Short, novel syntheses of lactones and furans of marine origin. Gazz. Chim. Ital. 1993, 123, $317-320$.

[100] Katsumura, S.; Ichikawa, K.; Mori, H. Synthesis of tetrasubstituted butenolide, bromobeckerelide, by regioselective lithiation of furan followed by photosensitized oxygenation of $\alpha$-silylfuran. Chem. Lett. 1993, 22, 1525-1528.

[101] De March, P.; Font, J.; Gracia, A.; Qingying, Z. Easy access to 5-alkyl-4-bromo-2(5H)-furanones: synthesis of a fimbrolide, an acetoxyfimbrolide, and bromobeckerelide. J. Org. Chem. 1995, 60, 1814-1822.

[102] Sorg, A.; Siegel, K.; Brückner, R. A novel access to $\gamma-$ alkylidenebutenolides: sequential Stille couplings of dibromomethylenebutenolides. Synlett 2004, 321-325.

[103] Manny, A. J.; Kjelleberg, S.; Kumar, N.; de Nys, R.; Read, R. W.; Steinberg, P. Reinvestigation of the 
sulfuric acid-catalyzed cyclization of brominated 2alkyllevulinic acids to 3-alkyl-5-methylene-2 $(5 H)$ furanones. Tetrahedron 1997, 53, 15813-15826.

[104] Galeyeva, Y.; Morr, M.; Sasse, F.; Diestel, R.; Laschat, S.; Baro, A.; Frey, W. Ex chiral pool synthesis of highly methyl-branched was ester and biological properties of (+)-capensifuranone. Z. Naturforsch. 2009, 64b, 639645.

[105] Galeyeva, Y.; Helbig, S.; Morr, M.; Sasse, F.; Nimitz, M.; Laschat, S.; Baro, A. Total synthesis and biological evaluation of (-)-pectinatone employing a methylbranched was ester as key builiding block. Chem. Biodiv. 2006, 6, 935-941.

[106] Herber, C.; Breit, B. Iterative deoxypropionate synthesis based on a copper-mediated direct allylic substitution: formal synthesis of borrelidin (C3-C11 fragment). Chem. Eur. J. 2006, 12, 6684-6691.

[107] Williams, D. R.; Nold, A. L.; Mullins, R. J. Asymmetric conjugate addition for the preparation of syn-1,3-dimethyl arrays: synthesis and structure elucidation of capensifuranone. J. Org. Chem. 2004, 69, 5374-5382.

[108] Beukes, D. R.; Davies-Coleman M. T. Novel polypropionates from the South-African marine mollusc Siphonaria capensis. Tetrahedron 1999, 55, 4051-4056.

[109] Steenackers, H. P.; Levin, J.; Janssens, J. C.; De Weerdt, A.; Balzarinim J.; Vanderleyden, J.; De Vos, D. E.; De Keersmaecker, S. C. Structure-activity relationship of brominated 3-alkyl-5-methylene-2 $(5 H)$ furanones and alkylmaleic anydrides as inhibitors of Salmonella biofilm formation and quorum sensing bioluminescence in Vibrio harveyi. Bioorg. Med. Chem. 2010, 18, 5224-5233.

[110] Elming, N.; Clauson-Kaas, N. Preparation of some 5substituted 2-oxo-2,5-dihydrofurans from 2acetoxyfuran. Acta Chem. Scand. 1952, 6, 565-568.

[111] Doerr, I. L.; Willette, R. E. $\alpha, \beta$-Insaturated lactones I. Condensation of 5-bromo-2 $(5 H)$-furanone with adenine and uracil derivatives. J. Org. Chem. 1973, 38, 38783887.

[112] Steyn, P. S.; Conradie, W. J.; Garbers, C. F.; De Vries, M. J. Bromination of but-2-enolides with $\mathrm{N}$ bromosuccinimide. J. Chem. Soc. 1965, 3075-3079.

[113] Martin R.; Chapleo, C. B.; Svanholt, K. L.; Dreiding, A. S. Synthese von bromosubstituirten butenolides II. Helv. Chim. Acta 1976, 59, 2724-2727.

[114] Edgar, M. T.; Pettit, G. R.; Smith, T. H. Synthesis of 3aryl-5-bromo-2(5H)-furanones. J. Org. Chem. 1978, 43, 4115-4120.

[115] Martin, H.; Hoffmann, R.; Schmidt, B.; Wolff, S. Preparation of 5-bromotetronates [4-alkoxy-5-bromo$2(5 H)$-furanones] and a new concept for the synthesis of aflatoxins and related structure types. Tributyltin hydride versus palladium-promoted intramolecular hydroarylation. Tetrahedron 1989, 45, 6113-6126.
[116] Taylor, G. A. Mucobromic acid. Org. Synth. Coll. 1963, $4,844$.

[117] Allen, C. F. H.; Spangler, F. W. Mucobromic acid. Org. Synth. Coll. 1955, 27, 688.

[118] Cooney, D. A.; Milman, H. A.; Jayaram, H. N.; Elton, R. Inhibition of $L$-asparagine synthase by mucochloric and mucobromic acid. Enzyme 1976, 21, 524-539.

[119] LaLonde, R. T.; Leo, H. R. Interactive chlorine-bybromine and hydrogen-by-hydroxyl group replacement effects in 2(5H)-furanone mutagenicity. Chem. Res. Toxicol. !994, 7, 779-783.

[120] Liviac, D.; Creus, A.; Marcos, R. Genotoxicity analysis of two hydroxyfuranones, byproducts of water disinfection, in human cells treated in vitro. Environ Mol. Mutagen. 2009, 50, 413-420.

[121] Krasner, S. W.; Weinberg, H. S.; Richardson, S. D.; Pastor, S. J.; Chinn, R.; Sclimenti, J.; Onstad, G. D.; Thruston, A. D. Jr. Occurrence of a new generation of disinfection byproducts. Environ. Sci. Technol. 2006, 40, $7175-7185$.

[122] Yang, C.; Song, G.; Zhu, Q.; Liu, S.; Xia, C. The influence of bacterial quorum sensing inhibitors against the formation of diatom biofilm. Chem. Ecol. 2016, 32, 169-181.

[123] Bellina, F.; Anselmi, C.; Rossi, R. Total synthesis of rubrolide $\mathrm{M}$ and some unnatural congeners. Tetrahedron Lett. 2002, 43, 2023-2027.

[124] Lespieau, Viguier. Sur 1'acide $\gamma$-oxytétrolique. Compt. Rend. 1908, 146, 294-296.

[125] Dupont, G.; Dulou, R.; Lefebvre, G. Oxidation of 2,3dibromo-2-butane-1,4-diol. Bull. Chim. Soc. Fr. 1951, 339-340.

[126] Bellina, F.; Rossi, R. An efficient and inexpensive multigram synthesis of 3,4-dibromo- and 3,4-dichloro2(5H)-furanone. Synthesis 2007, 1887-1889.

[127] Zhang, J.; Blazecka, P. G.; Berven, H.; Belmont, D. Metal-mediated allylation of mucohalic acids: facile formation of $\gamma$-allylic $\alpha, \beta$-unsaturated $\gamma$-butyrolactones. Tetrahedron Lett. 2003, 44, 5579-5582.

[128] Zhang, J.; Sarma, K. D.; Curran, T. T.; Belmont, D. T.; Davidson, J. G. Efficient synthesis of novel $\gamma$-substituted $\gamma$-butenolides by Lewis acid catalyzed addition of metal enolates of active methylene compounds to mucohalic acids. J. Org. Chem. 2005, 70, 5890-5895.

[129] Angele, P.; Zhang, J.; Belmont, D.; Curram T.; Davidson, J. G. Mucohalic acid in Lewis acid Mukaiyama aldol reaction: a concise method for highly functionalized $\gamma$-substituted $\gamma$-butenolides. Tetrahedron Lett. 2005, 46, 2029-2032.

[130] Zhang, J.; Blazecka, P. G.; Curran, T. T. Lewis and Brönsted acid catalyzed Friedel-Crafts hydroxyalkylation of mucohalic acids: a facile synthesis of functionalized $\gamma$-aryl $\gamma$-butenolides. Tetrahedron Lett. 2007, 48, 2611-2615.

[131] Sarma, K. D.; Zhang, J.; Curran, T. T. Novel synthons from mucochloric acid: the first use of $\alpha, \beta$-dichloro- $\gamma$ - 
butenolides and $\gamma$-butyrolactams for direct vinylogous aldol reaction. J. Org. Chem. 2007, 72, 3311-3318.

[132] Liu, G.-Y.; Guo, B.-Q.; Chen, W.-N.; Cheng, C.; Zhang, Q.-L.; Dai, M.-B.; Sun, J.-R.; Sun, P.-H.; Chen, W.-M. Synthesis, molecular docking and biofilm formation inhibitory activity of 5-substituted 3,4-dihalo$5 \mathrm{H}$-furan-2-one derivatives on Pseudomonas aeruginosa. Chem. Biol. Drug Des. 2012, 79, 628-638.

[133] Bjarnsholt, T.; Kirketerp-Moller, K.; Jensen, P. D.; Madsen, K. G.; Phipps, R.; Krogfelt, K.; Hoiby, N.; Givskov, M. Why chronic wounds will not heal: a novel hypothesis. Repair Regen. 2008, 16, 2-10.

[134] Stewart, P. S., Costerton, J. W. Antibiotic resistance of bacteria in biofilms. Lancet 2001, 358, 135-138.

[135] Walters, M. C. 3rd; Roe, F.; Bugnicourt, A.; Franklin, M. J.; Stewart, P. S. Contribution of antibiotic penetration, oxygen limitation, and low metabolic activity to tolerance of Pseudomonas aeruginosa biofilms to ciprofloxacin and tobramycin. Antimicrob. Agents Chemother. 2003, 47, 317-323.

[136] Ramachandran, C. V. S.; Sreekumar, P. K. Synthesis, characterization and antibacterial evaluation of $2(5 \mathrm{H})$ furanone derivatives from highly functionalized mucobromic acid. Int. J. Pharm. Pharm. Sci. 2011, 3, 225-228.

[137] Cardellach, J.; Estopa, C.; Font, J.; Moreno-Mañas, M.; Ortuño, R. M.; Sanchez-ferrando, F.; Valle, S.; Vilamajo, L. Studies on structurally simple $\alpha, \beta$ butenolides I. New syntheses of racemic $\gamma$ hydroxymethyl- $\alpha, \beta$-butenolide and derivatives. Tetrahedron 1982, 38, 2377-2394.

[138] Beechan, C. M.; Sims, J. J. The first synthesis of fimbtolides, a novel class of halogenated lactones naturally occurring in the red seaweed Delisia fimbriata (Bonnemaisoniaceae). Tetrahedron Lett. 1979, 20, 1649-1652.

[139] Kazlauskas, R.; Murphy, R. T.; Quinn, R. J.; Wells, R. J. A new class of halogenated lactones from the red alga Delisea fimbriata (Bonnemaisoniaceae). Tetrahedron Lett. 1977, 18, 37-40.

[140] De Nys, R.; Coll, J. C.; Bowden, B. F. Delisea pulchra (cf. fimbriata) revisited. The structural determination of two new metabolites from the red alga Delisea pulchra. Aust. J. Chem. 1992, 45, 1625-1632.

[141] De Nys, R.; Wright, A. D.; König, G. M.; Sticher, O. New halogenated furanones from the marine alga Delisea pulchra (cf. fimbriata). Tetrahedron 1993, 49, 11213-11220.

[142] McCombs, J. D.; Blunt, J. W.; Chambers, M. V.; Munro, M. H. G.; Robinson, W. T. Novel 2(5H)furanones from the red marine alga Delisea elegans (Lomouroux). Tetrahedron 1988, 44, 1489-1502.

[143] Daniels, R.; Reynaert, S.; Hoekstra, H.; Verreth, C.; Janssens, J.; Braeken, K.; Fauwart, M.; Beullens, S.; Heusdens, C.; Lambrichts, I.; De Vos, D. E.; Vanderleyden, J.; Vermant, J.; Michiels, J. Quorum signal molecules as biosurfactants affecting swarming in Rhizobium etli. PNAS 2006, 103, 14965-14970.

[144] Hughes, E. D.; Watson, H. B. CCLV. The reaction of bromine with aliphatic acids. Part III $\alpha$ - and $\gamma$-ketonic acid. J. Chem. Soc. 1929, 1945-1954.

[145] Caine, D.; Ukachukvu, V. C. A new synthesis of 3-nbutyl-4-bromo-5(Z)-(bromomethylene)-2(5H)-furanone, a naturally occurring fimbrolide from Delisea fimbriata (Bonnemaisoniaceae). J. Org. Chem. 1985, 50, 21952198.

[146] Lowery, C. A.; Abe, T.; Park, J.; Eubanks, L. M.; Sawada, D.: Kaufmann, G. F.; Janda, K. D. Revisiting Al-2 quorum sensing inhibitors: direct comparison of alkyl-DPD analogues and a natural product fimbrolide. J. Am. Chem. Soc. 2009, 131, 15584-15585.

[147] Srinivasan, S.; Östling, J.; Charlton, T.; de Nys, R.; Takayama, K.; Kjelleberg, S. Extracellular signal molecule(s) involved in the carbon starvation response in marine Vibrio sp. strain S14. J. Bacteriol. 1998, 180, 201-209.

[148] Rasmussen, T. B.; Manefield, M.; Andersen, J. B.; Eberl, L.; Anthoni, U.; Christophersen, C.; Steinberg, P.; Kjelleberg, S.; Givskov, M. How Delisea pulchra furanones effect quorum sensing and swarming motility in Serratia liquefaciens MG1. Microbiology 2000, 146, 3237-3244.

[149] Ren, D.; Sims, J. J.; Wood, T. K. Inhibition of biofilm formation and swarming of Escherichia coli by (5Z)-4bromo-5-(bromomethylene)-3-butyl-2(5H)-furanone. Environ. Microbiol. 2001, 3, 731-736.

[150] Ren, D.; Sims, J. J.; Wood, T. K. Inhibition of biofilm formation and swarming of Bacillus subtilis by bromo5-(bromomethylene)-3-butyl-2(5H)-furanone. Lett. Appl. Microbiol.2002,34, 293-299.

[151] Duanis-Assaf, D.; Steinberg, D.; Chai, Y.; Shemesh, M. The LuxS based quorum sensing governs lactose induced biofilm formation by Bacillus subtilis. Front. Microbiol. 2016, 6,1517; doi: 10.3389/fmicb.2015.0517.

[152] Ren, D.; Bedzyk, L. A.; Setlow, P.; England, D. F.; Kjelleberg, S.; Thomas, S. M.; Ye, R. W.; Wood, T. K. Differential gene expression to investigate the effect of (5Z)-4-bromo-5-(bromomethylene)-3-butyl-2(5H)furanone in Bacillus subtilis. Appl. Environ. Microbiol. 2004, 70, 4941-4949.

[153] Ren, D.; Wood, T. K. (5Z)-4-Bromo-5(bromomethylene)-3-butyl-2(5H)-furanone reduces corrosion from Desulfotomaculum orientis. Environ. Microbiol. 2004, 6, 535-540.

[154] Stintzi, A.; Evans, K.; Meyer, J.-m.; Poole, K. Quorum sensing and siderophore biosynthesis in Pseudomonas aeruginosa: lasR/lasl mutants exhibit reduced pyoverdine biosynthesis. FEMS Microbiol. Lett. 1998, 166, 341-345

[155] Ren, D.; Zuo, R.; Wood T. K. Quorum sensing antagonist (5Z)-4-bromo-5-(bromomethylene)-3-butyl$2(5 H)$-furanone influences siderophore biosynthesis in 
Pseudomonas putida and Pseudomomas aeruginosa. Appl. Microbiol. Biotechnol. 2005, 66, 689-695.

[156] For leading references on the siderephore biosynthesis in Pseudomonas aeruginosa, see: (a) Gasser, V.; Guillon, L.; Cunrath, O.; Schalk, I. J. Cellular organization of siderophore biosynthesis in Pseudomonas aeruginosa: evidence of siderosomes. $J$. Inorg. Biochem. 2015, 148, 27-34; (b) Clevenger, K. D.; Wu, R.; Er, J. A. V.; Liu, D.; Fast. W Rational design of a transition state analogue with picomolar affinity for Pseudomonas aeruginosa PvdQ, a siderophore biosynthetic enzyme. ACS Chem. Biol. 2013, 8, 21922200; (c) Guillon, L.; Altenburger, S.; Graumann, P. L.; Schalk, I. J. Deciphering protein dymanics of the siderophore pyoverdine pathway in Pseudomonas aeruginosa. PLoS ONE 2013, 8, e79111. Doi: 101371/journal.pone.0079111; (d) Yeterian, E.; Martin, L. W.; Guillon, L.; Journet, L.; Lamont, I. L.; Schalk, I. J. Synthesis of the siderophore pyoverdine in Pseudomonas aeruginosa involves a periplasmic maturation. Amino Acids 2010, 38, 1447-1459; (e) McMorran B. J.; Kumara, H. M- C. S.; Sulliva, K.; Lamont, I. L. Inolvement of a transformylase enzyme in siderophore synthesis in Pseudomonas aeruginosa. Microbiology 2001, 147, 1517-1524; (f) Meyer, J. M.; Neely, A.; Stintzi, A.; Gerges, C.; Holder, I. A. Pyoverdin is essential for virulence of Pseudomonas aeruginosa. Infect. Immun. 1996, 64, 518-523.

[157] Jones, M. B.; Jani, R.; Ren, D.; Wood, T. K.; Blaser, M. $\mathrm{J}$. Inhibition of Bacillus anthracis growth and virulencegene expression by inhibition of quorum sensing. $J$. Infect. Dis. 2005, 191, 1881-1888.

[158] Zang, T.; Lee, B. W. K.; Cannon, L. M.; Ritter, K. A.; Dai, S.; Ren, D.; Wood, T. K.; Zhou, Z. S. A naturally occurring brominated furanone covalently modifies and inactivates LuXS. Bioorg. Med. Chem. Lett. 2009, 19, 6200-6204.

[159] Waters, C. M.; Bassler, B. L. Quorum sensing: cell-tocell communication in bacteria. Annu. Rev. Cell Dev. Biol. 2005, 21, 319-346.

[160] Duo, M.; Zhang, M.; Luk, Y.-Y.; Ren, D. Inhibition of Candida albicans growth by brominated furanones. Appl. Microbiol. Biotechnol. 2010, 85, 1551-1563.

[161] Kuehl, R.; Al-Bataineh, S.; Gordon, O.; Luginbuehl, R.; Otto, M.; Textor, M.; Landmann, R. Furanone at subinhibitory concentrations enhances staphylococcal biofilm formation by luxS repression. Antimicrob. Agents Chemether. 2009, 53, 4159-4166.

[162] LaLonde, R. T.; Bu., L.; Henwood, A.; Fiumano, J.; Zhang, L. Bromine-, chlorine- and mixed halogensubstituted 4-methyl-2( $5 H)$-furanones: synthesis and mutagenic effects of halogen and hydroxyl group replacements. Chem. Res. Toxicol. 1997, 10, 1427-1436.

[163] Benneche, T.; Hussain, Z.; Scheie, A. A.; LönnStensrud, J. Synthesis of 5-(bromomethylene)furan$2(5 H)$-ones and 3-(bromometjhylene)isobenzofuran-
$1(3 H)$-ones as inhibitors of microbial quorum sensing. New. J. Chem. 2008, 32, 1567-1572.

[164] Davidson, B. S.; Ireland, C. M. Lissoclinolide, the first non-nitrogenous metabolite from a Lissoclinum tunicate. J. Nat. Prod. 1990, 53, 1036-1038.

[165] (a) Thomulka, K. Wm.; Peck, L. H. Use of bioluminescence in detecting biohazardous substances in water. In Tested studies for laboratory teaching. 1995, Volume 16, Goldman C. A. Ed.. Proceedings of the 16th Workshop/Conference of the Association for Biology Laboratory Education (ABLE(, 273 pages; (b) Thomulka, K. W.; Lange, J. H. Use of the bioluminescent bacterium Vibrio harveyi to detect biohazardous chemicals in soil and water extractions with and withot acid. Ecotoxicol. Environ. Saf. 1995, 32, 201-204.

[166] Benneche, T.; Chamgodani, E. J.; Reimer, I. A new synthesis of five-membered heterocyclic quorum sensing inhibitors. Tetrahedron Lett. 2012, 53, 6982-6983.

[167] Persson, T.; Johansen, S. K.; Martiny, L.; Givslov, M.; Nielsen, J. Synthesis of carbon-14 labelled (5Z)-4bromo-5-(bromomethylene)-2(5H)-furanone: a potent quorun sensing inhibitor. J. Label. Compd. Radiopharm. 2004, 47, 627-634.

[168] Smith, R. S.; Harris, S. G.; Phipps, R.; Iglewski, B. The Pseudomonas aeruginosa quorum-sensing molecule $N$ 83-oxododecanoyl)homoserine lactone contributes to virulence and induces inflammation in vivo. J. Bacteriol. 2002, 184, 1132-1139.

[169] Khalizadeh, P.; Lojoie, B.; El Hage, S.; Furiga, A.; Baziard, G.; Berge, M.; Roques, C. Growth inhibition of adherent Pseudomonas aeruginosa by an $N$-butanoyl- $L$ homoserine lactone analog. J. Microbiol. 2010, 56, 317325.

[170] Pande, G. S. J.; Scheie, A. A.; Benneche, T.; Wille, M.; Sorgeloos, P.; Bossier, P.; Defoirdt, T. Quorum sensingdisrupting compounds protect larvae of the giant freshwater prawn Macrobrachium resenbergii from Vibrio harveyi infection. Aquaculture 2013, 406-407, 121-124.

[171] Cheng, Y.; Zhao, X.; Liu, X.; Sun, W.; Ren, H.; Gao, B.; Wu, J. Antibacterial actiovity and biological performance of a novel antibacterial coating containing a halogentade furanone compound loaded poly $(L$-lactic acid) nanoparticles on microarc oxidized titanium. Int. J. Nanoscience 2015, 10, 727-737.

[172] Wu, Y.; Quan, X.; Si, X. Incorporatiopn of brominated furanone into Nafion polymer enhanced anti-biofilm efficacy. Int. Biodeter. Biodegrad. 2015, 99, 39-44.

[173] Zhao, Y.; Chen, P.; Nan, W.; Zhi, D.; Liu, R.; Li, H. The use of (5Z)-4-bromo-5-(bromomethylene)-2(5H)furanone for controlling acid mine drainage through the inhibition of Acidithiobaciluus ferrooxidans biofil formation. Bioresour. Technol. 2015, 186, 52-57.

[174] Han, Y.; Hou, S.; Simon, K. A.; Ren, D.; Luk, Y.-Y. Identifying the important structural elements of 
brominated furanones for inhibiting biofilm formation by Escherichia coli. Bioorg. Med. Chem. Lett. 2008, 18, 1006-1010.

[175] (a) Pan, J.; Bahar, A. A.; Syed, H.; Ren, D. Reverting antibiotic tolerance of Pseudomonas aeruginosa PAO1 persister cells by (Z)-4-bromo-5-(bromomethylene)-3methyl-furan-2(5H)-one. PLoS One 2012, 7: e45778; (b) Lewis, K. Persister cells. Annu. Rev. Microbiol. 2010, 64, 357-372.

[176] Pan, J.; Xie, X.; Tian, W.; Bahar, A. A.; Lin, N.; Song, F.; An, J.; Ren, D. (Z)-4-Bromo-5-(bromomethylene)-3methyl-furan-2(5H)-one sensitizes Escherichia coli persister cells to antibiotics. Appl. Microbiol. Biotechnol. 2013, 97, 9145-9154.

[177] Pen, J.; Song, F.; Ren, D. Controlling persister cells of Pseudomomas aeruginosa PDO300 by (Z)-4-bromo-5(bromomethylene)-3-methyl-furan-2(5H)-one. Bioorg. Med. Chem. Lett. 2013, 23, 4648-4651.

[178] Iskander, G.; Zhang, R.; Chan, D. S-H.; Black, D. Stc.; Alamgir, M.; Kumar, N. An efficient synthesis of brominated 4-alkyl-2(5H)-furanones. Tetrahedron Lett. 2009, 50, 4613-4615.

[179] Pereira, U. A.; Moreira, T. A.; Barbosa, L. C. A.; Maltha, C. R. A.; Bomfin, I. S.; Maranhão., S. S.; Moraes, M. O.; Pessoa, C.; Barros-Nepomuceno, F. W. A. Rubrolide analogues and their derived lactams as potential anticancer agents. Med. Chem. Commun. 2016, 7, 345-352.

[180] Tikkanen, L.; Kronberg, L. Genotoxic effects of various chlorinated butenoic acids identified in chlorinated drinking water. Mutat. Res. 1990, 240, 109-116.

[181] Meier, J. R.; Blazak, W. F.; Knohl, R. B.; Mutagenic and clastegenic properties of 3-chloro-4(dichloromethyl)-5-hydroxy-2(5H)-furanone, a potent bacterial mutagen in drinking water. Environ. Mol. Mutagen. 1987, 10, 411-424.

[182] Kronberg, L.; Holmbom, B.; Reunanen, M.; Tikkanen, L. Identification and quantification of the Ames mutagenic compound 3-chloro-4-(dichloromethyl)-5hydroxy-2(5H)-furanone and its geometric isomer, $(E)$ 2-chloro-3-(dichloromethyl)-4-oxobutanoic acid in chlorine-treated humic water and drinking water extracts. Environ. Sci. Technol. 1988, 22, 1097-1103.

[183] Lloveras, M.; Ramos, I.; Molins, E.; Messeguer, A. Improved synthesis of three brominated analogues of the potent environmental mutagen 3-chloro-4(dichloromethyl)-5-hydroxy-2(5H)-furanone.

Tetrahedron 2000, 56, 3391-3397.

[184] Suzuki, N.; Nakanishi, J.. Brominated analogues of MX () in chlorinated drimking waters. Chemosphere 1995, 30, 1557-1564.

[185] Havel, K. P.; Argade, N. P. Synthesis of natural fimbrolides. Synthesis 2007, 2198-2204.

[186] Haefliger, W.; Petrzilka, T. Synthesen substituirter btenolide. Helv. Chim. Acta 1966, 49, 1937-1950.
[187] Kotsuki, H.; Monden, M.; Ochi, M. Efficient synthesis of acetoxyfimbrolides and beckerelides analogs. Chem. Lett. 1983, 12, 1007-1008.

[188] Calderón, A.; de March, P.; Font, J. Synthesis of 3-(1hydroxyalkyl)furan-2 $(5 H)$-ones: unexpectes substitutionn reaction in allylic alcohols by bromine. $J$. Org. Chem. 1987, 52, 4631-4633.

[189] Ramos, I.; Lloveras, M.; Solans, X.; Huici, A.; Messeguer, A. Brominated analogs of 3-chloro-4(dichloromethyl)-5-hydroxy-2(5H)-furanone: preparation of 3-chloro-(4-bromochloromethyl)-5hydroxy-2 $(5 H)$-furanone and mutagenicity studies. Environ. Toxicol. Chem. 2000, 19, 2631-2636.

[190] Lumbard, K. W.; Nixon, N. S.; Scheinmann, F. A simple synthesis of brominated analogues of 3-chloro-4(dichloromethyl)-5-hydroxy-2(5H)-furanone (MX). Synth. Commun. 2003, 33, 3411-3417.

[191] Bellina, F.; Anselmi, C.; Martina, F.; Rossi, R. Mucochloric acid: a useful synthhon for the selective synthesis of 4-aryl-3-chloro-2 $(5 H)$-furanones, $(Z)$-4-aryl5-[1-(aryl)methylidene]-3-chloro-2(5H)-furanones and 3,4-diaryl-2(5H)-furanones. Eur. J. Org. Chem. 2003, 2290-2302.

[192] Sorg, A.; Siegel, K.; Brückner, R. Stereoselective synthesis of dihydroxerulin and xerulinic acid, antihyypocholesterolemic dyes from the fungus Xerula melanotricha. Chem. Eur. J. 2005, 11, 1610-1624.

[193] Benneche, T.; Lönn, J.; Scheie, A. A. Synthesis of (E)and (Z)-5-(bromomethylene)furan-2 $(5 H)$-one by bromodecarboxylation of (E)-2-(5-oxofuran-2(5H)ylidene)acetic acid. Synth. Commun. 2006, 36, 14011404.

[194] Massy-Westropp, R. A.; Price, M. F. The synthesis of 5-oxo-2,5-dihydrofuran-2-ylideneacetic acids. Aust. J. Chem. 1980, 33, 333-341.

[195] Homsi, F.; Rousseau, G. Halodecarboxylation of $\alpha, \beta-$ acetylenic and $\alpha, \beta$-ethylenic acids. Tetrahedron Lett. 1999, 40, 1495-1498. For more recent literature data on the halodecarboxylation reaction see: (a) Naskar, D.; Das, S. K.; Giribabu, L.; Maiya, B. G.; Roy, S. Novel catalytic Hunsdiecker-Heck $(\mathrm{CHH})$ strategy toward all- $E$ stereocontrolled ferrocene-capped conjugated push-pull polyenes. Organometallics 2000, 19, 1464-1469; (b) Naskar, D.; Roy, S. Catalytic Hunsdiecker reaction and one-pot catalytic Hunsdiecker-Heck strategy: synthesis of $\alpha, \beta$-unsaturated aromatic halides, $\alpha$ (dihalomethyl)benzenemethanols, 5-aryl-2,4pentadienoic acids, dienoates and dienamides. Tetrahedron 2000, 56, 1369-1377; (c) Kuang, C.; Yang, Q.; Senboku, H.; Tokuda, M. Stereoselective synthesis of (E)- $\beta$-arylvinyl bromides by microwave-induced Hunsdiecker reaction. Synthesis 2005, 1319-1325; (d) Rajanna, K. C.; Reddy, N. M.; Reddy, M. R.; Saiprakash, P. K. Micellar mediated halodecarboxylation of $\alpha, \beta$-unsaturated aliphatic and aromatic carboxylic acids - A novel green Hunsdiecker-Borodin reaction. $J$ 
Dispers. Sci. Technol. 2007, 28, 613-616; (e) Nikishin, G. I.; Sokova, L. L.; Makhaev, V. D.; Kapustina, N. I. Solid-phase oxidative halodecarboxylation of $\beta$ arylacrylic acids with ceric ammonium nitrate-alkali halide system. Russ. Chem. Bull. Int. Ed. 2008, 57, 118123; (f) Galletti, P.; Quintavalla, A.; Ventrici, C.; Giacomini, D. Halodecarboxylation reaction of 4alkylidene- $\beta$-lactams. Eur. J. Org. Chem. 2009, 45414547; (g) Carbain, B.; Hitchcock, P. B.; Streicher, H. New aspects of the Hunsdiecker-Barton halodecarboxylation-syntheses of phospha-shikimic acid and derivatives. Tetrahedron Lett. 2010, 51, 2717-2719; (h)Zych, A. J.; Wang, H.-J.; Sakwa, S. A. Sybthesis and Suzuki-Miyaura reactions of 5-halo-3,4dihydropyrimidin-2(1H)-ones. Tetrahedron Lett. 2010, 51, 5103-5105.

[196] Benneche, T.; Chamgordani, E. J.; Reimer, I. A new synthesis of five-membered heterocyclic quorun sensing inhibitors. Tetrahedron Lett. 2012, 53, 6982-6983.

[197] Hentzer, M.; Riedel, K.; Rasmussen, T. B.; Heydorn, A.; Andersen, J. B.; Parsek, M. R.; Rice, S. A.; Eberl, L.; Molin, S.; Høiby, N.; Kjelleberg, S.; Givskov, M. Inhibition of quorum sensing in Pseudomonas aeruginosa biofilm bacteria by a halogentaed furanone compound. Microbiology 2002, 148, 87-102.

[198] Lönn-Stensrud, J.; Petersen, F. C.; Benneche, T.; Scheie, A. A. Synthetic bromated furanone inhibits autoinducer-2-mediated communication and biofilm formation in oral streptococci. Oral Microbiol. Immunol. 2007, 22, 340-346.

[199] Vestby, L. K.; Johannsen, K. C. S.; Witsø, I. L.; Habimana, O.; Scheie, A. A.; Urdahl, A. M.; Benneche, T.; Langsrud, S.; Nesse, L. L. Synthetic brominated furanone F202 prevents biofilm formation by potentially human pathogenic Escherichia coli O103:H2 and Salmonella ser. Agona on abiotic surfaces. J. Appl. Microbiol. 2013, 116, 258-268.

[200] Shetye, G. S.; Singh, N.; Gåo, X.; Bandyopadhyay, D.; Yan, A.; Luk, Y.-Y. Structures and biofilm inhibition activities of brominated furanones for Escherichia coli and Pseudomonas aeruginosa. Med. Chem. Commun. 2013, 4, 1079-1084.

[201] Anary-Abbasinejad, M.; Hassanabadi, A.; Gavarti, M. A. Efficient one-pot synthesis of 2-(bromomethyl)-2-(4aryl)-4-alkoxy-5-oxo-2,5-dihydrofuran-3-carboxylate. Synth. Commun. 2012, 42, 1426-1431.

[202] Sabbah, M.; Bernollin, M.; Doutheau, A.; Soulère, L.; Queneau, Y. A new route towards fimbrolide analogues: importance of the exomethylene motif in LuxR dependent quorum sensing inhibition. Med. Chem. Commun. 2013, 4, 363-366.

[203] Bloemberg, G. V.; O’Toole, G. A.; Lugtenberg, B. J. J.; Kolter, R. Green fluorescent protein as a marker for Pseudomonas spp. Appl Environ. Microbiol. 1997, 63, 4543-4551.
[204] Pour, M.; Špulák, M.; Balsánek, V.; Kunes, J.; Buchta, V.; Waisser, K. 3-Phenyl-5-methyl-2H,5H-furan-2-ones: tuning antifungal activity by varying substituents on the phenyl ring. Bioorg. Med. Chem. Lett. 2000, 10, 18931895.

[205] Pour, M.; Špulák, M.; Buchta, V.; Kubanová, P.; Vopršalova, M.; Wsól, V.; Fáková, H.; Kouìdelka, P.; Pourová, H.; Schiller, R. 3-Phenyl-5-acyloxymethyl$2 \mathrm{H}, 5 \mathrm{H}$-furan-2-one: synthesis and biological activity of a novel group of potential antifungal drugs. J. Med. Chem. 2001, 44, 2701-2706.

[206] Buchta, V.; Pour, M.; Kubanová, P.; Silva, L.; Votruba, I.; Vopršalová, M.; Schiller, R.; Fáková, H.; Špulák, M. In vitro activitites of 3-(halogenated phenyl)-5acyloxymethyl-2,5-dihydrofuran-2-ones against common and emerging yeasts and molds. Antimicrob. Agents Chemother. 2004, 48, 873-878.

[207] Vele-Silva, L.; Buchta, V.; Vokurková, D.; Pour, M. Investigation of the mechanism of action of 3-(4bromophenyl)-5-acyloxymethyl-2,5-dihydrofuran-2-one against Candida albicans by flow cytometry. Bioorg. Med. Chem. Lett. 2006, 16, 2492-2495.

[208] Šenel, P.; Tichotová, L.; Votruba, I.; Buchta, V.; Špulák, M.; Kuneš, J.; Nobilis, M.; Krenk, O.; Pour, M. Antifungal 3,5-disubstituted furanones: From 5acyloxymethyl to 5-alkylidene derivatives. Bioorg. Med. Chem. 2010, 18, 1988-2000.

[209] Mao, W.; Zhu, C. Synergistic acid-promoted synthesis of highly substituted butenolides via annulation of ketoacids and tertiary alcohols. Org. Lett. 2015, 17, 5710-5713.

[210] Manna, M. S.; Mukherjee, S.; Catalytic asymmetric direct vinylogous Michael addition of deconjugated butenolides to maleimides for the construction of quaternary stereogenic centers. Chem. Eur. J. 2012, 18, 15277-15282.

[211] Nakamura, S.; Yamaji, R.; Hayashi, M. Direct enantioselective vinylogous Mannich reaction of ketimines with $\gamma$-butenolide by using cinchona alkaloid amide/zinc(II) catalysts. Chem Eur. J. 2015, 21, 96159618.

[212] Masumoto, S.; Usuda, H.; Suzuki, H.; Suzuki, M.; Kanai, M.; Shibasaki, M. Catalytic enentioselective Strecker reaction of ketimines. J. Am. Chem. Soc. 2003, $125,5634-5635$.

[213] Boulangé, A.; Parraga, J.; Galán, A.; Cabedo, N.; Leleu, S.; Sanz, M. J.; Cortes, D.; Franck, X. Synthesis and antibacterial activitites of cadiolides A, B and C and analogues. Bioorg. Med. Chem. 2015, 23, 3618-3628.

[214] Smith, C. J.; Hettich, R. L.; Jompa, J.; Tahir, A.; Buchanan, M. V.; Ireland, C. M. Cadiolides A and B, new metabolites from an ascidian of the genus Botryllus. J. Org. Chem. 1998, 63, 4147-4150.

[215] Wang, W.; Kim, H.; Nam, S.-J.; Rho, B. J.; Kang, H. Antibacterial butenolides from the Korean tunicate 
Pseudodistoma antiboja. J. Nat. Prod. 2012, 75, 2049 2054.

[216] Kotora, M.; Negishi, E.-i. Highly efficient and selective provcedures for the synthesis of $\gamma$-alkylidenebutenolides via palladium-catalyzed ene-yne coupling and palladium- or silver-catalyzed lactonization of (Z)-2-en4-ynoic acids. Synthesis of rubrolides A, C, D and E. Synthesis 1997, 121-128.

[217] Tale, N. P.; Shelke, A. V.; Tiwari, G. B.; Thorat, P. B.; Karade, N. N. New concise and efficient synthesis of rubrolides $\mathrm{C}$ and $\mathrm{E}$ via intramolecular Wittig reaction. Helv. Chim. Acta 2012, 95, 852-857.

[218] Boukouvalas, J.; McCann, L. C. Synthesis of thge human aldose reductase inhibitor rubrolide $\mathrm{L}$. Tetrahedron Lett. 2010, 51, 4636-4639.

[219] Manzanaro, S.; Salvá, J.; de la Fuente, J. A. Phenolic marine natural products as aldose reductase inhibitors. $J$. Nat. Prod. 2006, 69. 1485-1487.

[220] Carroll, A. R.; Healy, P. C.; Quinn, R. J.; Tranter, C. J. Prunolides A, B, and C: novel tetraphenolic bisspiroketals from the Australian ascidian Synoicum prunum. J. Org. Chem. 1999, 64, 2680-2682.

[221] Boukouvalas, J.; Pouliot. M. Short and efficient synthesis of cadiolide B. Synlett 2005, 343-345.

[222] Jefford, C. W.; Jaggi, D.; Boukouvalas, J. Regioslective aldol condensation of boron and tin furanolates with aldehydes: an improved synthesis of 2-(1'hydroxyalkyl)butenolides. J. Chem. Soc. Chem. Commun. 1988, 1595-1596.

[223] Peixoto, P. A.; Boulangé, A.; Leleu, S.; Franck, X. Versatile synthesis of acylfuranones by reaction of acylketenes with $\alpha$-hydroxy ketones: application to the one-step multicomponent synthesis of cadiolide B and analogues. Eur. J. Org. Chem. 2013, 3316-3327.

[224] Smitha, D.; Kumar, M. M.; Ramana, H.; Rao, D. V. Rubrolide R: a new furanone metabolite from the ascidian Synoicum of the Indian ocean. Nat. Prod. Res. 2014, 28, 12-17.

[225] Boukouvalas, J.; Thibault, C. Step-economical synthesis of the marine ascidian antibiotics cadiolide A, B, and C. J. Org. Chem. 2015, 80, 681-684.

[226] Liang, J.; Hu, W.; Tao, P.; Jia, Y. Total synthesis of dictyodendrins B an d E. J. Org. Chem. 2013, 78, 5810 5815.

[227] Roy, S.; Davydova, M. P.; Pal, R.; Gilmore, K.; Tolstikov, G. A.; Vasilevsky, S. F.; Alabugin, I. V. Dissecting alkynes: full cleavage of polarized $\mathrm{C} \equiv \mathrm{C}$ moiety via sequential bis-Michael addition/retroMannich cascade. J. Org. Chem. 2011, 76, 7482-7490.

[228] Waldo, J. P.; Larock, R. C. The synthesis of highly substituted isoxazoles by electrophilic cyclization: an efficient synthesis of Valdecoxib. J. Org. Chem. 2007, 72m 9643-9647.

[229] Kutty, S. K.; Barraud, N.; Pham, A.; Iskander, G.; Rice, S. A.; Black, D. Stc.; Kumar, N. Design, synthesis, and evaluation of fimbrolide-nitric oxide donor hybrids as antimicrobial agents. J. Med. Chem. 2013, 56, 95179529.

[230] Kumar, L.; Sharma, V.; Mahajan, T.; Agarwal, D. D. Instantaneous, facile and selective synthesis of tetrabromobisphenol A using potassium tribromide: an efficient and renewable brominating agent. Org. Process Res. Dev. 2010, 14, 174-179.

[231] Barraud, N.; Hassett, D. J.; Hwang, S. H.; Rice, S. A.; Kjelleberg, S.; Webb, J. S. Involvement of nitric oxide in biofilm dispersal of Pseudomonas aeruginosa. J. Bacteriol. 2006, 188, 7344-7353.

[232] Barraud, N.; Storey, M. V.; Moore, Z. P.; Webb, J. S.; Rice, S. A.; Kjelleberg, S. Nitric oxide-mediated dispersal in single and multi-species biofilms of clinically and industrially relevant microorganisms. Microb. Biotechnol. 2009, 2, 370-378.

[233] Hentzer, M.; Givskov, M. Pharmacological inhibition of quorum sensing for the treatment of chronic bacterial infections. J. Clin. Invest. 2003, 112, 1300-1307.

[234] Defordt, T.; Boon, N.; Bossier, P. Can bacteria evolve resistance to quorum sensing disruption? PLoS Pathog. 2010, 6: e1000989: doc: 101.371 -journal.ppat.1000989.

[235] Nazzaro, F.; Fratianni, F.; Coppola, R. Quorum sensing and phytochemicals. Int. J. Mol. Sci. 2013, 14, 1260712619.

[236] Maeda, T.; Garciá-Contreras, R.; Pu, M.; Sheng, L.; Garcia, L. R.; Tomás, M.; Wood, T. K. Quorum quenching mandary: resistance to antivirulence compounds. ISME J. 2012, 6, 493-501.

[237] Garciá-Contreras, R.; Martínez-Vázquez, M.; Guadarrama, N. V.; Guadalupe, A.; Pañeda, V.; Hashimoto, T.; Maeda, T.; Quezada, H.; Wood, T. K. Resistance to the quorum-quenching compounds brominated furanone $\mathrm{C}-30$ and 5-fluorouracil in Pseudomonas aeruginosa clinical isolates. Pathog. Dis. 2013, 68, 8-11.

[238] Kalia, V. C.; Wood, T. K.; Kumar, P. Evolution of resistance to quorum sensing inhibitors. Microb. Ecol. 2014, 68, 13-23.

[239] For liteature data on the use of acomniations of antibacterial compounds with efflux pump inhibitors, see: (a) Handzlik, J.; Matys, A.; Kiec-Konowicz, K. Recent advances in multi-drug resistance (MDR) efflux pump inhibitors of Gram-positive bacteria $S$. aureus. Antibiotics 2013, 2, 28-45; (b) Liger, F.; Bouhours, P.; Ganem-Elbaz, C.; Jolivalt, C.; Pellet-Rostaing, S.; Popowycz, F.; Paris, J.-M.; Lemaire, M. C2 Arylated benzo[b]thiophene derivatives as Stapylococcus aureus NorA efflux pump inhibitors. ChemMedChem 2016, 11, 320-330.

[240] For literature data on efflux pump inhibitors as antimicrobial agents, see: (a) Marquez, B. Bacterial efflux systems and efflux pumps inhibitors. Biochimie 2005, 87, 1137-1147; (b) Askoura, M.; Mottawea, W.; Abujamel, T.; Taher, I. Efflux pump inhibitors (EPIs) as antimicrobial agents against Pseudomonas aeruginosa. 
Libyan J. Med. 2011, 6, $5870 \quad$ - DOI: 103402/ljm.v6i0.5870.

[241] Ankisetty, S.; Nandiraju, S.; Win, H.; Park, Y. C.; Amsler, C. D.; McClintock, J. B.; Baker, J. A.; Diyabalanage, T. K.; Pasaribu, A.; Singh, M. P.; Maiese, W. M.; Walsh, R. D.; Zaworotko, M. J.; Baker, B. J. Chemical investigation of predator-deterred macroalgae from Antarctic peninsula. J. Nat. Prod. 2004, 67, 12951302. 


\section{Biographical sketch}

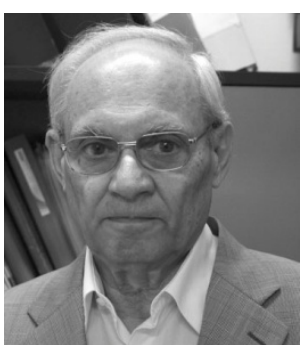

Renzo Rossi was born in Pisa (Italy) and graduated in Organic Chemistry with first-class honours at the University of Pisa defending a thesis performed under the guidance of Professor Piero Pino. In 1969 he became Assistant Professor and in 1971 he earned the libera docenza in Organic Chemistry. After holding other intermediate positions at the University of Pisa and the Scuola Normale Superiore of Pisa, in 1980 he became Full Professor of Organic Chemistry at the University of Calabria. In 1982, he again joined the University of Pisa where he has held the Chair of Chemistry of Naturally Occurring Compounds. In 1999, the University of Pisa awarded him the Ordine del Cherubino. His current research interests include: i) new catalytic methods for the synthesis of oxygen-containing heterocycles; ii) the preparation of substances which exhibit significant cytotoxicity against human tumor cell lines and antivascular properties; iii) the study of new methodologies for carbon-carbon bond formation that involve the use of organometallic reagents; $i v$ ) palladium-catalyzed cross-coupling reactions; $v$ ) transition metal-catalyzed direct arylation reactions of substrates with activated $\mathrm{sp}^{3}$-hybridized $\mathrm{C}-\mathrm{H}$ bonds with aryl halides and pseudohalides; vi) the design, development and applications of new, highly chemo- and regioselective methods for the transition metal-catalyzed direct $C$ - and $N$-arylation reactions of electron-rich heteroaromatic systems, including free (NH)azoles, with aryl halides and pseudohalides, and their application in the synthesis of bioactive natural and unnatural compounds. In recent years, several successful studies have also been performed by his research group in the field of the synthesis and evaluation of the biological properties of insect sex pheromone components, insecticidal carboxyamides, natural phototoxins, and naturally-occurring compounds of marine origin and their structural analogues possessing the 2(5H)-furanone ring. Professor Rossi, who has coauthored over 235 research publications and a number of highly cited review articles and patents, is a fellow of the Royal Society of Chemistry and the American Chemical Society. He is a reviewer for several international journals dealing with synthetic organic chemistry and organometallics.

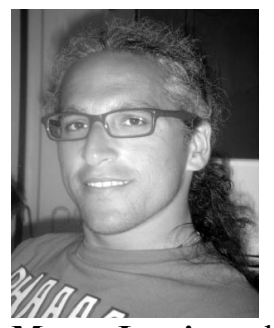

Marco Lessi was born in Livorno (Italy) in 1979. He studied Chemistry at the University of Pisa and received his Laurea Degree with first-class honours in June 2004 defending a thesis performed under the guidance of Professor Dario Pini. In January 2005, he began his PhD fellowship in the laboratory of Professor Pini and received his PhD degree in 2008, submitting a thesis on the preparation and applications of new insoluble polymer-bound (IPB) enantioselective catalytic systems. The studies were focused on the synthesis of transition metal complexes obtained from bisoxazoline and BINOL ligands. In the period January 2008-March 2009, Dr. Lessi worked for Solvay Solexis S.p.A. on the development of new routes for the preparation of high-fluorinated low-molecular-weight molecules and oligomers. In March 2009, he re-joined the University of Pisa, and at present he is an organic chemistry researcher, working in the group of Professor Bellina. The research interests of Dr. Lessi involve the development of novel and efficient protocols for highly selective transition metal-catalyzed direct $\mathrm{C}\left(\mathrm{sp}^{3}\right)$ $\mathrm{H}$ and $\mathrm{C}\left(\mathrm{sp}^{2}\right)-\mathrm{H}$ arylation reactions, and the discovery of new synthetic routes and applications of functionalized ionic liquids obtained from naturally-occurring building blocks.

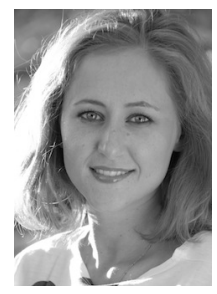


Chiara Manzini was born in Lucca (Italy) in 1986 and graduated in Chemistry with first-class honours at the University of Pisa in 2011. In January 2012, she began his PhD fellowship in the laboratory of Professor Bellina and received his PhD degree in 2015, submitting a thesis on the on the development and application of new protocols for the selective arylation of $\mathrm{N}$ containing heteroaromatics.

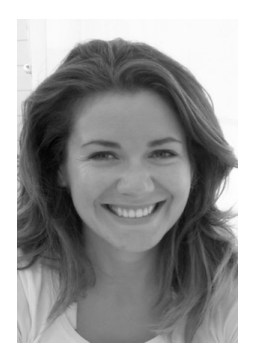

Giulia Marianetti was born in Lucca (Italy) in 1988 and graduated in Organic Chemistry with first-class honours at the University of Pisa in 2013. She currently holds a PhD scholarship at the Scuola Normale Superiore of Pisa under the supervision of Prof. Fabio Bellina and Prof. Vincenzo Barone. She is currently working on the synthesis and the computational studies of new organic fluorophores.

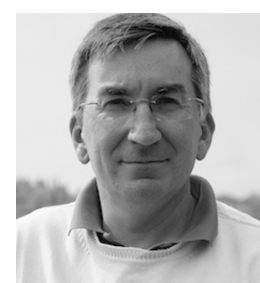

Fabio Bellina was born in Catania (Italy) in 1964. He studied Chemistry at the University of Pisa and received his Laurea Degree with first-class honours in 1990. In 1992, he joined the University of Pisa as an Organic Chemistry Researcher in the Department of Chemistry and Industrial Chemistry. In October 2003, he was appointed by the Faculty of Science of the University of Pisa as an Associate Professor of Organic Chemistry and, in January 2016, he became Full Professor of Organic Chemistry at the same University. His research interests were initially devoted to the synthesis of naturally occurring compounds of biological and/or pharmacological interest and to the synthesis of structural analogues of natural fungicidal derivatives of agrochemical interest. More recently, Prof. Bellina focused his attention on new protocols for regioselective transition metal-mediated carbon-carbon and carbon-heteroatom bond forming reactions, with a particular interest in the selective functionalization of oxygen-containing unsaturated heterocycles such as $2(5 H)$-furanones and $2(2 H)$-pyranones. Currently, he is working on the development of novel protocols for the transition metal-catalyzed direct $\mathrm{C}-\mathrm{H}$ and $\mathrm{N}-\mathrm{H}$ bond arylation of heteroarenes with a focus on direct arylation reactions and cross dehydrogenative couplings, the alkynylation of (hetero)aromatic scaffolds, and on the application of these new procedures to the selective preparation of bioactive natural and synthetic compounds and to new organic chromophores. 